\title{
Bestuurskosten in de gezondheidszorg
}

Citation for published version (APA):

Hermans, M. (1992). Bestuurskosten in de gezondheidszorg. [Doctoral Thesis, Maastricht University]. Datawyse / Universitaire Pers Maastricht. https://doi.org/10.26481/dis.19921217mh

Document status and date:

Published: 01/01/1992

DOI:

10.26481/dis.19921217mh

Document Version:

Publisher's PDF, also known as Version of record

\section{Please check the document version of this publication:}

- A submitted manuscript is the version of the article upon submission and before peer-review. There can be important differences between the submitted version and the official published version of record.

People interested in the research are advised to contact the author for the final version of the publication, or visit the DOI to the publisher's website.

- The final author version and the galley proof are versions of the publication after peer review.

- The final published version features the final layout of the paper including the volume, issue and page numbers.

Link to publication

\footnotetext{
General rights rights.

- You may freely distribute the URL identifying the publication in the public portal. please follow below link for the End User Agreement:

www.umlib.nl/taverne-license

Take down policy

If you believe that this document breaches copyright please contact us at:

repository@maastrichtuniversity.nl

providing details and we will investigate your claim.
}

Copyright and moral rights for the publications made accessible in the public portal are retained by the authors and/or other copyright owners and it is a condition of accessing publications that users recognise and abide by the legal requirements associated with these

- Users may download and print one copy of any publication from the public portal for the purpose of private study or research.

- You may not further distribute the material or use it for any profit-making activity or commercial gain

If the publication is distributed under the terms of Article $25 \mathrm{fa}$ of the Dutch Copyright Act, indicated by the "Taverne" license above, 


\section{BESTUURSKOSTEN IN DE GEZONDHEIDSZORG}




\section{BESTUURSKOSTEN IN DE GEZONDHEIDSZORG}

\section{PROEFSCHRIFT}

ter verkrijging van de graad van doctor

aan de Rijksuniversiteit Limburg te Maastricht, op gezag van de Rector Magnificus, Prof. Mr. M.J. Cohen, volgens het besluit van het College van Dekanen, in het openbaar te verdedigen op donderdag, 17 december 1992 om 16.00 uur

door

\section{Monique Hermans}

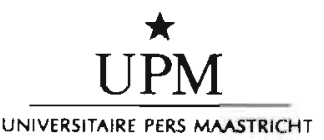




\section{Promotor:}

Prof.dr. J.A.M. Maarse

Beoordelingscommissie:

Prof.mr. F.C.B. van Wijmen (voorzitter)

Dr. R.T.J.M. Janssen

Prof.dr. R.M. Leidl

Dr. I.M. Mur-Veeman

Prof.dr. A.A. de Roo (KUB)

Prof.dr. A.J.P. Schrijvers (RUU)

Hermans, Monique

Bestuurskosten in de gezondheidszorg / Monique Hermans. Maastricht: Universitaire Pers Maastricht. - III.

Proefschrift. - Met lit. opg. - Met

samenvatting in het Engels.

ISBN 90-5278-047-1

NUGI $681 / 757$

Trefw.: gezondheidszorg; financiering

Omslagontwerp: Benoît Hermans

Met dank aan:

- Fonds Doctor Catherine van Tussenbroek

- Stichting Het Scholten-Cordes Fonds

voor de financiële bijdragen in de drukkosten. 


\section{INHOUDSOPGAVE}

Hoofdstuk 1 Naar een probleemstelling

1.1 Inleiding 5

1.2 De groei van overheidsbesturing 6

1.3 Bestuurskosten in de gezondheidszorg 9

$\begin{array}{lll}1.4 & \text { Probleemstelling } & 11\end{array}$

1.5 Hoofdstukindeling 12

\section{Hoofdstuk 2 Bestuurskosten}

$2.1 \quad$ Inleiding 15

2.2 Besturingsinstrumenten in de gezondheidszorg 16

2.3 Plaats van de bestuurskosten binnen de economie 20

2.4 Definities van bestuurskosten 22

2.5 Afbakening en definitie van bestuurskosten 30

2.6 Problemen bij de afbakening 31

2.7 Samenvatting en conclusies 33

\section{Hoofdstuk 3 Bestuurskosten op begrotingen ?}

3.1 Inleiding 35

3.2 Bestuurskosten op begrotingen en jaarrekeningen 36

3.3 Bestuurskosten en de prestatiebegroting 41

3.4 Samenvatting en conclusies $\quad 44$

Hoofdstuk 4 Meting van bestuurskosten

$\begin{array}{lll}4.1 & \text { Inleiding } & 45\end{array}$

4.2 Methodologische criteria 46

$\begin{array}{lll}4.3 & \text { Aggregatieniveaus en meeteenheden } & 47\end{array}$

4.4 Mogelijke dataverzamelingsmethoden 50

4.5 De meting van de bestuurskosten in de gezondheidszorg 56

4.6 Samenvatting en conclusies 58

Hoofdstuk 5 Bestuurskosten in het Financieel Overzicht

$5.1 \quad$ Inleiding 59

5.2 De voorlopers van het Financieel Overzicht 60

5.2.1 De doeleinden van het Financieel Overzicht 61

5.2.2 Het bereik van het Financieel Overzicht 64

5.2.3 De staatsrechtelijke status van het Financieel Overzicht 65

5.2.4 De totstandkoming van het Financieel Overzicht 66

5.2.5 De opbouw van het Financieel Overzicht 68

5.2.6 Het Financieel Overzicht en de stelselwijziging 72

5.3 De bepaling van de bestuurskosten $\quad 74$

5.3.1 Het hoofdstuk "kosten van beleid, administratie en beheer" 74

5.3.1.1 De opbouw van het hoofdstuk "kosten van beleid, administratie en beheer"

5.3.1.2 De totstandkoming van het hoofdstuk "kosten van beleid, administratie en beheer"

5.3.1.3 De hoogte van de kosten van beleid, administratie en beheer $\quad 78$

5.3.1.4 De verdeling van de kosten van beleid, administratie en beheer $\quad 82$

5.3.2 Aanvullingen op het hoofdstuk "kosten van beleid, administratie en beheer" in guldens

5.3.3 Aanvullingen op het hoofdstuk "kosten van beleid, administratie en beheer" in aantallen formatieplaatsen 
5.4 Evaluatie van de bepaling van de bestuurskosten als aanvulling op pagina het Financieel Overzicht

5.5 Samenvatting en conclusies

\section{Hoofdstuk 6 Bestuurskosten in doorlooptijd}

$6.1 \quad$ Inleiding

6.2.1 Achtergrond: artikel 18 Wet Ziekenhuisvoorzieningen 98

6.2.2 De artikel 18-voorzieningen

6.2.3 De procedure voor vergunningaanvragen 104

6.2.4 Kritiek op de werking van artikel 18

6.3 De meting van de bestuurskosten van artikel 18

6.3.1 De doorlooptijd van de totstandkoming van planningsbesluiten

6.3.2 De doorlooptijd van de afhandeling van vergunningaanvragen

6.4 Evaluatie van de meting van de bestuurskosten van artikel 18

6.5 Samenvatting en conclusies

\section{Hoofdstuk 7 Bestuurskosten in bestede tijd}

$7.1 \quad$ Inleiding

7.2.1 Achtergrond: artikel 4 Wet Ziekenhuisvoorzieningen

7.2.2 De planprocedure conform de Wet Ziekenhuisvoorzieningen

7.2.3 De planprocedure volgens de Wet Ziekenhuisvoorzieningen en de Wet Voorzieningen Gezondheidszorg in de provincie Limburg

7.2.4 De invulling van de planprocedure door de provincie Limburg

7.3 De meting van de bestuurskosten van artikel 4

7.3.1 De in de praktijk gevolgde planprocedure vòòr Dekker en de tijd die deze in beslag heeft genomen

7.3.2 De in de praktijk gevolgde planprocedure nà Dekker en de tijd die deze beslag heeft genomen

7.4 Evaluatie van de meting van de bestuurskosten van artikel 4

\section{Hoofdstuk 8 Conclusies}

$8.1 \quad$ Inleiding

8.2 De probleemstelling beantwoord

8.3 Eindconclusies

8.4 Beleidsimplicaties

SAMENVATTING 


\section{Hoofdstuk 1}

\section{NAAR EEN PROBLEEMSTELLING}

\section{$\S 1.1 \quad$ Inleiding}

De reden om dit onderzoek uit te voeren is gelegen in de toename van de bestuurskosten in de gezondheidszorg. Bestuurskosten in de gezondheidszorg worden hier voorlopig omschreven als de kosten van de bestuurlijke infrastructuur die niet gerelateerd zijn aan de directe zorgverlening. Later volgt een nadere definitie. De groei van de bestuurskosten is niet los te zien van de groei van overheidsbesturing. De overheidsbesturing is met name in de afgelopen decennia in vrijwel alle aspecten van het dagelijkse leven toegenomen. Voorts is ook in de gezondheidszorg sprake van groei van overheidsbesturing waardoor de complexiteit van de gezondheidszorg is toegenomen. Zo wordt een ziekenhuis niet langer alleen bestuurd door een geneesheer-directeur. Naast hem staat tegenwoordig een directeur-beheerszaken. Bovendien is sprake van een uitgebreide staf en informatiediensten. In termen van Mintzberg zijn de "support- en technostructures" gegroeid. De interne besturing van de instellingen, de relaties tussen de ziekenhuizen onderling en met bijvoorbeeld verzekeraars zijn ingewikkelder geworden. Het aanknopen en onderhouden van dergelijke contacten kost meer inspanning en deze activiteiten veroorzaken een toename van de bestuurskosten.

Twijfel is gerezen omtrent de effectiviteit van overheidsbesturing. De overheidsbesturing neernt weliswaar alsmaar toe, maar of deze toename in relatie staat tot de verwachte effecten, is de vraag (zie onder meer Commissie-Dekker, 1987). Bestond daarover meer zekerheid, dan zou een zekere toename van de bestuurskosten acceptabel zijn. Voor zover echter twijfel bestaat over de effectiviteit van de overheidsbesturing, wordt het moeilijk de groei van de hiermee verbonden bestuurskosten te rechtvaardigen. 
Tegen deze achtergrond is de belangstelling voor de bestuurskosten toegenomen. De Nationale Raad voor de Volksgezondheid wijst sinds 1983 op het feit dat de "kosten van beleid, administratie en beheer" in het Financieel Overzicht aanzienlijk sterker stijgen dan de kosten van de overige sectoren. Bovendien pleit de Raad voor een betere inventarisatie van de bestuurskosten (Nationale Raad voor de Volksgezondheid, 1983 en volgende jaren).

De groei van bestuurskosten in de gezondheidszorg is geen exclusief Nederlands probleem. Ook internationaal staan de bestuurskosten in de belangstelling. In de Verenigde Staten is eveneens aangedrongen op meer aandacht voor de bestuurskosten. Met name Woolhandier en Himmelstein (1986; 1991) en Reinhardt (1991) wijzen op het toegenomen aandeel van de bestuurskosten genoemde kosten in de totale kosten van de gezondheidszorg. Deze veronderstelling lijkt te worden bevestigd door onderzoek van de United States General Accounting Office (1991). Hierin worden het Canadese genationaliseerde en het Amerikaanse particuliere ziektekostenverzekeringsstelsel met elkaar vergeleken. De "administration costs" van de verzekeraars, ziekenhuizen en specialisten blijken in het Amerikaanse stelsel aanzienlijk hoger te zijn.

In Nederland is de discussie omtrent de bestuurskosten tegenwoordig weer actueel naar aanleiding van de plannen met betrekking tot de stelselwijziging van de ziektekostenverzekering. De Ziekenfondsraad heeft een schatting gemaakt van de gevolgen van de stelselwijziging voor de beheerskosten van de verzekeraars. Uit deze schatting blijkt dat de bestuurskosten, door de Ziekenfondsraad aangeduid als "beheerskosten", aanmerkelijk zullen stijgen.

\section{§1.2 De groei van overheidsbesturing}

De overheidsbesturing op het gebied van de gezondheidszorg is gegroeid. Dit geldt niet uitsluitend voor de gezondheidszorg. In het algemeen is de overheidsbesturing toegenomen (Hoogerwerf, 1977). De groei van de overheidsbesturing is het resultaat van een complex geheel van factoren. Hierbij valt te denken aan de economische onwikkeling, maatschappelijke en internationale crises, veranderende opvattingen over de rol van de overheid, maatschappelijke en politieke strijd.

De overheidsbesturing heeft vooral na de Tweede Wereldoorlog een snelle ontwikkeling doorgemaakt. Doordat de ontreddering groot was, lag de nadruk van de overheidsbemoeienis aanvankelijk vooral op de wederopbouw van de gezondheidszorgvoorzieningen. Voorts werd de overheidsbesturing aanzienlijk geïntensiveerd en uitgebreid. Dit kwam tot uitdrukking in de wijziging van de Gezondheidswet in 1956, waarmee werd beoogd de samenwerking tussen de overheid en particuliere instanties te bevorderen. Tevens regelde de herziene Gezondheidswet de inspectie op de volksgezondheid. Bovendien kwam wetgeving tot stand op het gebied van de financiële toegankelijkheid, zoals de Ziekenfondswet (1966) en de Algemene Wet Bijzondere Ziektekosten (1968). Daarnaast werden de tarieven gereguleerd. Dit gebeurde aanvankelijk door middel van de Wet Ziekenhuistarieven (1965), die later werd vervangen door de Wet Tarieven Gezondheidszorg (1982) (Juffermans, 1982). Krachtens de Wet Tarieven Gezondheidszorg werd ook de ziekenhuisbudgettering ingevoerd.

Het tempo waarin gezondheidszorgvoorzieningen tot stand werden gebracht, leidde in de loop van de jaren zestig tot de vrees dat in sommige gebieden overlap 
zou ontstaan en in andere witte viekken. Deze vrees kwam tot uiting in de Volksgezondheidsnota 1966 (1965-1966). Deze nota betekende een keerpunt in de overheidsbesturing van de gezondheidszorg. Hierin werd namelijk naar voren gebracht dat de overheid zodanige voorwaarden diende te scheppen dat iedereen zijn recht op gezondheid kon realiseren. Dit impliceerde een dusdanige beschikbaarheid van gezondheidszorgvoorzieningen dat sprake moest zijn van een goede ordening en van een doelmatig functionerende zorg. In $1971 \mathrm{kwam}$ in dit kader de eerste versie van de Wet Ziekenhuisvoorzieningen gereed. Deze moest de bouw en spreiding van de intramurale gezondheidszorg regelen. In de Structuurnota Gezondheidszorg (1974) borduurde staatssecretaris Hendriks op dit pleidooi voor ordening voort. Zo constateerde hij dat het stelsel van voorzieningen een lappendeken vormde. Om die reden werd planning van voorzieningen door middel van regionalisatie en echelonnering bepleit. Met het oog hierop zou de Wet Ziekenhuisvoorzieningen moeten worden vervangen door de Wet Voorzieningen Gezondheidszorg (1982). Deze zou zowel de intra- als de extramurale zorg omvatten. Mede door twijfels omtrent de uitvoerbaarheid is de Wet Voorzieningen Gezondheidszorg inmiddels alweer ingetrokken. De Wet Ziekenhuisvoorzieningen is echter nog steeds van kracht, zij het in afgeslankte vorm. De Commissie-Dekker heeft in de nota "Verandering verzekerd" (1987) immers gepleit voor een terugtred van de overheid ten gunste van het veld.

In de loop van de jaren zeventig is de verzorgingsstaat, die na de Tweede Wereldoorlog is ontstaan, steeds meer onder druk komen te staan. Dit is het gevolg van de alsmaar stijgende collectieve uitgaven sinds de tweede wereldoorlog, de toename van het financieringstekort en de uitbreiding van het aantal regelingen (Heroverweging "Wettelijke voorschriften in verband met de economische ontwikkeling", 1981-1982). Postma (1983) geeft aan dat nu wellicht een overgang van de verzorgingsstaat naar de waarborgstaat (Roscam Abbing spreekt over een "bevorderingsstaat"; 1983) gewenst is. In een waarborgstaat garandeert de overheid bepaalde basisvoorzieningen, maar laat de rest over aan de verantwoordelijkheid van de burgers. Overigens is nu nog slechts sprake van plannen in de richting van een waarborgstaat. De echte "terugtred" moet nog beginnen en daarbij zullen nog heel wat politieke en andere obstakels opdoemen (Derksen, Drupsteen en Witteveen, 1989).

Voorlopig lijkt het er echter op, dat de uitbreiding van de overheidsbesturing van de gezondheidszorg blijt doorgaan. Een tekenend voorbeeld biedt de zogeheten "kleine stelselwijziging" van 1986. In het kader hiervan werden de bejaardenverzekering en de vrijwillige ziekenfondsverzekering opgeheven. Om de gevolgen van deze stelselwijziging op te vangen, was echter heel wat nieuwe wetgeving nodig. De ironie wil dat deze wetgeving per saldo een uitbreiding van de overheidsinvloed op de gezondheidszorg impliceerde, omdat de particuliere verzekeraars met steeds meer overheidsbesturing te maken kregen (Maarse, 1990).

Op de overheid wordt tevens een grote politieke druk uitgeoefend om met wetgeving inzake medisch-ethische vraagstukken te komen. Mede door de snelle technologische ontwikkelingen en de daardoor toenemende mogelijkheden en de toegenomen mondigheid van de consument groeit de behoefte aan wettelijke regeling van bepaalde vraagstukken. Kwesties als abortus, euthanasie, medische ethiek, patiëntenrechten en klachtenregelingen dienen door wetgeving te worden geregeld. 
Figuur 1.1 Uitgebrachte nota's, wetten en financieringsregelingen in het kader van de kosten van de gezondheidszorg

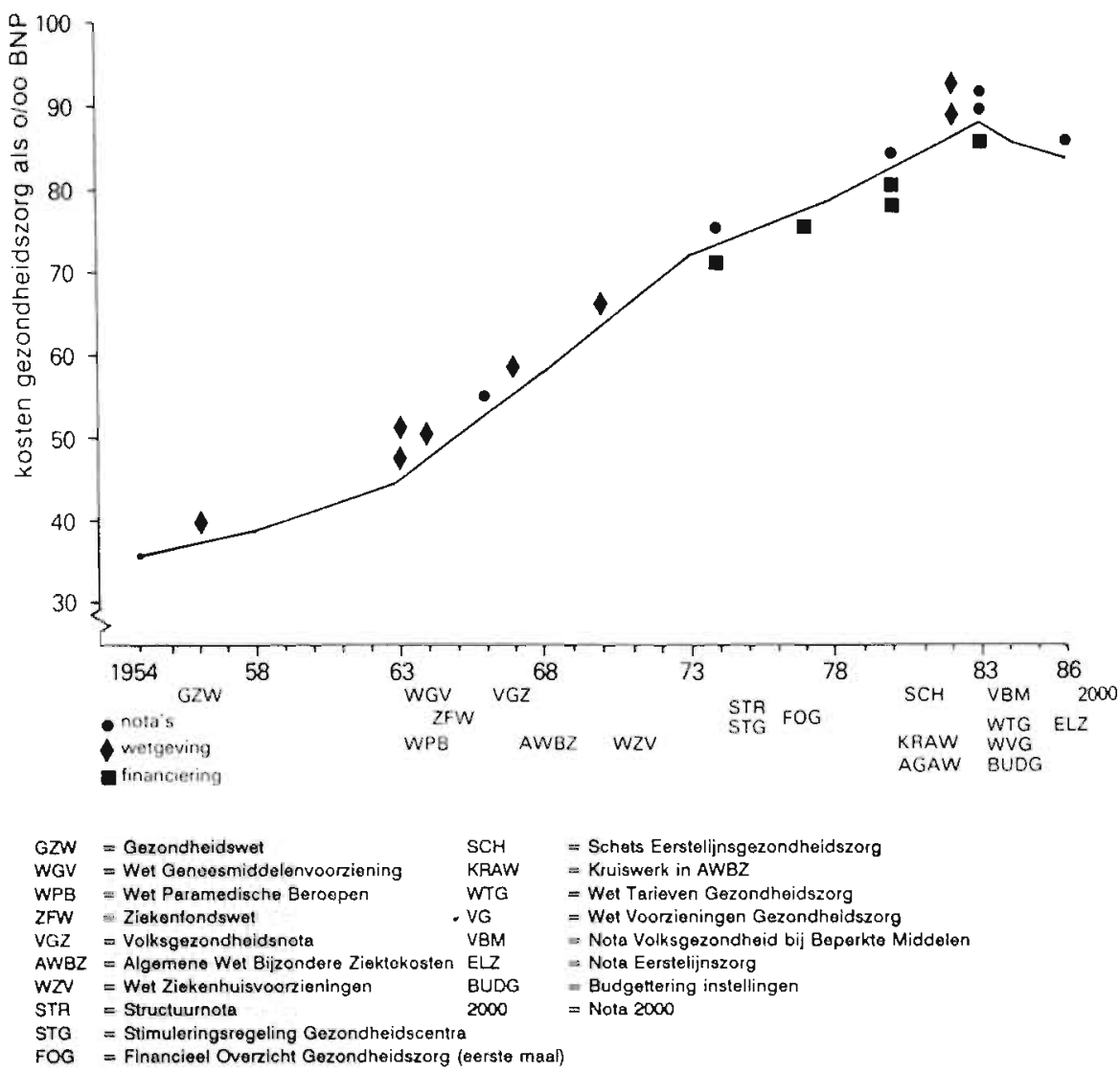

Bron: J. van der Zee

Het falen van het structuurbeleid in de gezondheidszorg 1987, p.24

Een illustratie van de groei van de overheidsbesturing in de gezondheidszorg biedt figuur 1.1. Van der Zee (1987) heeft in kaart gebracht hoe de relatie is tussen het percentage van het Bruto Nationaal Produkt dat wordt besteed aan de gezondheidszorg en het aantal nota's, wetten en financieringsregelingen die in het kader van de gezondheidszorg zijn genomen sinds 1954. Hieruit blijkt dat met het aantal uitgebrachte regelingen ook de kosten van de gezondheidszorg stijgen.

Men kan stellen dat de overheidsbesturing gedurende de afgelopen decennia aanzienlijk is toegenomen. Dit geldt eveneens voor de bestuurskosten. Van de overheid als nachtwaker is weinig meer over. Na een aantal decennia waarin van een verzorgingsstaat sprake is, gaan steeds meer stemmen op voor terugtred van 
de overheidsbesturing in de richting van een waarborgstaat. Deze trend is ook in de gezondheidszorg waarneembaar. Na een periode van alsmaar toenemende overheidsbemoeienis wordt in de gezondheidszorg steeds meer gepleit voor vermindering van de overheidsbesturing en toename van de eigen verantwoordelijkheid. Er zijn wel voornemens in die richting geuit, maar deze moeten nog ten uitvoer worden gebracht.

\section{§1.3 Bestuurskosten in de gezondheidszorg}

Bestuurskosten zijn de kosten van de bestuurlijke infrastructuur in de gezondheidszorg en niet de kosten van de zorgverlening. Bestuurskosten worden veroorzaakt door overheidsbesturing. Overheidsbesturing is het door middel van beleid richting geven aan de samenleving. Bestuurskosten worden gemaakt door overheden en particulieren, zoals ziekenhuizen, verzekeraars, adviesorganen.

Behalve deze beperkte benadering wordt ook een bredere definitie van bestuurskosten gehanteerd. Volgens deze benadering, die onder meer is terug te vinden bij Woolhandler en Himmelstein (1986; 1991), worden ook bestuurskosten gemaakt door de interne besturing van instellingen en door zelfregulering van instellingen. Voorbeelden van activiteiten waarbij bestuurskosten worden gemaakt zijn logistiek, roosterplanning, overleg. Bestuurskosten door zelfregulering doen zich voor door afwezigheid van overheidsbesturing. Wanneer de overheid niet reguleert, moeten verzekeraars contracten afsluiten met instellingen. Tijdens deze activiteiten genereren verzekeraars en instellingen bestuurskosten.

In dit proefschrift wordt de enge benadering van bestuurskosten gehanteerd, tenzij dit uitdrukkelijk anders wordt vermeld.

In het Financieel Overzicht worden de kosten per zorgsector gerubriceerd. Een van deze sectoren betreft "beleid, administratie en beheer". Wanneer men de kosten van deze sector met die van andere sectoren vergelijkt, blijkt dat de kosten van beleid, administratie en beheer een van de snelst stijgende te zijn. Zo zijn de kosten van beleid, administratie en beheer tussen 1972 en 1988 ruimschoots verviervoudigd, tenwijl de kosten van de intramurale sector ruim zijn verdrievoudigd (Centraal Bureau voor de Statistiek, 1991).

De aandacht voor de bestuurskosten neemt toe. Dit is niet alleen een gevolg van het feit dat de bestuurskosten zo sterk stijgen. Het is ook en misschien vooral een uitvloeisel van de twijfel over de effectiviteit van het overheidsbeleid ten aanzien van de gezondheidszorg. Met name de effecten van de structuurwetgeving die gedurende de afgelopen decennia is ingevoerd, zijn nauwelijks zichtbaar. Toch zijn de kosten van de uitvoering ervan aanzienlijk. Men hoeft hierbij slechts te denken aan de adviesstructuren en de procedures die dienen te worden doorlopen.

Zoals eerder vermeld is een bredere benadering van bestuurskosten mogelijk. Dit is met name relevant wanneer men de gevolgen van de stelselwijziging voor de bestuurskosten beschouwt. De stelselwijziging heeft immers een dimensie toegevoegd aan de bestuurskosten. Het doel van de stelselwijziging is vermindering van de overheidsbesturing ten gunste van sturing door het veld zelf. Of dit zal leiden tot een daling van de bestuurskosten is nog maar de vraag. Minder overheidsbesturing en meer marktwerking zullen er immers toe leiden dat het veld zelf meer bestuurskosten zal moeten maken. Dit is bijvoorbeeld het geval bij het afsluiten van 
contracten over volume, prijzen en kwaliteit. Of de totale bestuurskosten zullen dalen is de vraag. Wel zal een verschuiving optreden.

Eerder is reeds aangegeven, dat de belangstelling voor de bestuurkosten geen exclusief Nederlandse aangelegenheid is. Ook in de Verenigde Staten is momenteel discussie gaande over de toename van de bureaucratie in de gezondheidszorg. Deze heeft inmiddels tot bezorgdheid geleid omtrent de hoogte van de "nonclinical health expenditures". Reinhardt (1991) noemt dit de "medical B-factor", waarbij "B" staat voor bureaucratie. Hij zegt: "It is my contention, having studied health-care systems both here and abroad, that the American health system has the highest B-factor in the industrial world - that it is the most "bureaucratic" medicine to be found anywhere". Himmelstein en Woolhandler (1986; 1991) zijn ervan overtuigd dat de "health care administration costs" in de Verenigde Staten zo hoog zijn door het ontbreken van overheidsingrijpen. Hierbij gaat het echter voornamelijk om de "health care administration costs" van particulieren. Deze zijn hoger naarmate de overheid minder bestuurt en meer overlaat aan de particuliere markt. Himmelstein en Woolhandler leggen een verband tussen enerzijds de ingewikkelde administratie die een ziekenhuis moet voeren in verband met de vele verschillende verzekeraars en anderzijds de hoogte van de "health care administration costs". De verzekeraars besteden van hun kant veel geld aan het afrekenen, de marketing en het berekenen van de kosten. Een genationaliseerd systeem, zoals in Canada en Engeland, zou veel "health care administration costs" besparen, aidus Himmelstein en Woolhandler. In een van de vele reacties op deze publicatie werd echter aangevoerd dat het onlogisch is om de overheidsbureaucratie een grotere rol toe te kennen in een poging de bestuurskosten te verminderen. In hun weerwoord voeren Himmelstein en Woolhandler aan dat door de overheid geleide programma's, zoals Medicare en Medicaid, een derde van de overheadkosten genereren ten opzichte van de particuliere verzekeraars en dat commerciële ziekenhuizen meer gebureaucratiseerd zijn dan publieke ziekenhuizen.

Een vergelijking tussen de kosten van het Amerikaanse en van het Canadese gezondheidszorgsysteem heeft inmiddels aangetoond dat het Canadese genationaliseerde systeem aanzienlijk goedkoper is (United States General Accounting Office, 1991). Met name de kosten van de uitvoering van het ziektekostenverzekeringsstelsel liggen zowel bij de verzekerende instantie als bij instellingen en medische beroepsbeoefenaren in Canada aanzienlijk lager dan in de Verenigde Staten. Zo gaat bijvoorbeeld in Canada één procent van de uitgaven voor de gezondheidszorg per hoofd van de bevolking op aan de zogenoemde verzekeringsoverheadkosten, terwijl hieraan in de Verenigde Staten vijf procent wordt besteed.

Overigens is Danzon (1992) het niet met bovenstaande berekeningen eens. Zij zegt dat pleiters voor een publiek gezondheiszorgsysteem uitsluitend de kosten van de uitvoering van het verzekeringsstelsel bepalen, zonder rekening te houden met factoren, als langere wachttijden, frequenter en meer gebruik van medische voorzieningen. Per saldo zal daarom een publiek gezondheidszorgsysteem altijd duurder zijn dan een particulier systeem, aldus Danzon. Zij heeft haar betoog echter niet met cijfers onderbouwd.

Samenvattend kan worden geconcludeerd dat de bestuurskosten een groeiende belangstelling genieten. Het ontbreekt echter nog steeds aan een algemeen gebruikte afbakening van de bestuurskosten en aan systematische meting. De gehanteerde omschrijvingen lopen nogal uiteen. ledere onderzoeker of beleidsmaker lijkt zijn eigen definitie te hanteren. $\mathrm{Er}$ is tot dusverre geen sprake van een 
eenduidige, bruikbare en methodisch verantwoorde afbakening. De meting van bestuurskosten is daarom problematisch. Zolang immers een deugdelijke afbakening ontbreekt, kan ook geen sprake zijn van meting. Tot op heden is dan ook nog geen serieuze poging ondernomen om de bestuurskosten in de gezondheidszorg te meten. Alleen het Financieel Overzicht biedt hierin enig inzicht. Het Financieel Overzicht geeft echter uitsluitend een indruk van de bestuurskosten bij verzekeraars, adviesorganen en overheden. Bestuurskosten van bijvoorbeeld instellingen worden niet tot het hoofdstuk "kosten van beleid, administratie en beheer" gerekend. Niet bekend is hoe hoog de kosten zijn van de uitvoering van afzonderlijke wetten of beleidsprogramma's. Als gevolg van dit gebrek aan inzicht wordt de verhouding tussen de kosten en baten veroorzaakt door de vitvoering van een bepaalde maatregel, vertroebeld. Niet alleen ontbreekt een goed inzicht in de hoogte van de bestuurskosten, ook de verdeling van de bestuurskosten over de uitvoerders is onduidelijk. Bestuurskosten blijven immers niet beperkt tot de overheid. Particulieren, zowel organisaties als individuen zoals huisartsen en andere zelfstandige beroepsbeoefenaren, zijn eveneens betrokken bij de uitvoering van wetgeving. Men kan hierbij denken aan advisering of inspraak, maar ook aan het moeten naleven van bepaalde procedures. Daarom dragen ook particulieren bestuurskosten. Met het oog daarop is niet alleen meer inzicht in de hoogte van bestuurskosten gewenst, maar ook in de verdeling van de bestuurskosten over degenen die de kosten dragen.

\section{$\S 1.4$ Probleemstelling}

Het doel van dit onderzoek is inzicht te krijgen in manieren waarop bestuurskosten in de gezondheidszorg zouden kunnen worden gemeten. Om dit doel te bereiken is gekozen voor de volgende probleemstelling: hoe kan de omvang van de bestuurskosten in de gezondheidszorg worden gemeten? Het accent ligt dus op de vraag op welke manier de bestuurskosten kunnen worden gemeten en minder op de omvang van de bestuurskosten. De probleemstelling is opgedeeld in een aantal deelvragen. De deelvragen zijn op de volgende manier tot stand gekomer. $\mathrm{Er}$ bestaat onduidelijkheid omtrent de betekenis van het begrip bestuurskosten. Om tot operationalisering te kunnen komen, zal in de literatuur moeten worden nagegaan welke definities zoal worden gehanteerd. Daarom zal eerst worden ingegaan op de vraag: wat zijn bestuurskosten? Daartoe zullen de in de literatuur omtrent bestuurskosten gehanteerde begrippen en definities worden gegroepeerd en geanalyseerd. Tevens zal aandacht worden besteed aan een aantal theoretische benaderingen van het begrip bestuurskosten.

De vraag die vervolgens rijst is: waardoor worden bestuurskosten veroorzaakt? In deze studie zijn bestuurskosten het gevolg van overheidsbesturing. Het ligt voor de hand dat de bestuurskosten groeien naarmate de overheid uitgebreider bestuurt. Vandaar dat zal worden onderzocht welke instrumenten de overheid ter beschikking staan om te sturen. Hierbij kan men denken aan subsidies, heffingen, voorzieningen, informatie en wet- en regelgeving. Met name aan dit laatste instrument lijkt de overheid in de gezondheidszorg in de jaren zeventig en tachtig de voorkeur te geven.

De volgende deelvraag luidt: waar zijn bestuurskosten terug te vinden? Om antwoord te krijgen op deze vraag zal nagegaan worden hoe de begroting voor volksgezondheid van provincies en gemeenten is ingedeeld en of daarop de bestuurskosten tot uitdrukking worden gebracht. 
In het geval dat de bestuurskosten ontbreken op begrotingen of verborgen zijn in andere kostenposten, moeten zij worden gemeten. Om dit mogelijk te maken zijn afbakening en operationalisering van het begrip "bestuurskosten" noodzakelijk. De volgende vraag luidt daarom: hoe kunnen bestuurskosten worden geidentificeerd? Wanneer hierop een antwoord is gevonden, kan worden overgegaan tot meting. Naar aanleiding hiervan doet zich de vraag voor: hoe kunnen bestuurskosten worden gemeten? Hiertoe zal worden bekeken welke methoden geschikt zijn om bestuurskosten te meten.

Wanneer de bestuurskosten zijn geoperationaliseerd en de meest geschikte meetmethoden zijn geselecteerd, moet worden bepaald welke onderzoekseenheid zal worden gekozen. Met onderzoekseenheid wordt bedoeld het niveau waarop de meting zal plaatsvinden.

Wanneer deze methodisch-theoretische overwegingen zijn behandeld, kan met het empirische gedeelte worden begonnen. In dit deel zullen de eigenlijke metingen plaatsvinden. Door middel van de toepassing van de eerder gestelde methodologische en maatschappelijke criteria zal worden bezien of de gehanteerde meetmethoden geschikt zijn om de bestuurskosten te meten.

Samengevat zal antwoord worden gezocht op de volgende probleemstelling en onderzoeksvragen (zie schema 1.1).

Schema 1.1 Probleemstelling en onderzoeksvragen

probleemstelling:

hoe kan de omvang van de bestuurskosten in de gezondheidszorg worden gemeten?

onderzoeksvragen:

- wat zijn bestuurskosten?

- waardoor worden bestuurskosten veroorzaakt?

- waar zijn bestuurskosten terug te vinden?

hoe kunnen bestuurskosten worden geïdentificeerd?

hoe kunnen bestuurskosten worden gemeten?

zijn de gehanteerde methoden geschikt om de bestuurskosten te meten?

\section{§1.5 Hoofdstukindeling}

De hoofdstukindeling van deze studie is als volgt. In hoofdstuk 2 komt aan de orde welke instrumenten de overheid ter beschikking staan om de gezondheidszorg te besturen. Vervolgens wordt ingegaan op de transactiekostenbenadering. Deze theorie biedt een aanknopingspunt voor de bestuurskosten in de economie. Daarna volgt een overzicht van de manier waarop bestuurskosten elders zijn genoemd en gedefinieerd. Aan de hand hiervan worden de bestuurskosten nader afgebakend voor gebruik in deze studie. In hoofdstuk 3 wordt nagegaan of en waar bestuurskosten zijn terug te vinden op begrotingen van rijk, provincie en gemeente en op rekeningen van instellingen. Hoofdstuk 4 behandelt de methodologische criteria waaraan een meting moet voldoen en de aggregatieniveaus en meeteenheden van de meting van bestuurskosten. In hoofdstuk 5 komen de totstandkoming van het Financieel Overzicht en de opbouw van het hoofdstuk "kosten van beleid, administratie en beheer" aan de orde. Verder worden aanvullin- 
gen gegeven op de kosten van beleid, administratie en beheer. Hoofdstuk 6 vormt de weergave van de inventarisatie van de doorlooptijd van de uitvoering van artikel 18 van de Wet Ziekenhuisvoorzieningen. In hoofdstuk 7 worden de bestuurskosten in de vorm van de tijd besteed aan de uitvoering van artikel 4 van de Wet Ziekenhuisvoorzieningen bepaald. Hoofdstuk 8 tenslotte bevat een samenvatting van de conclusies en aanbevelingen. 



\section{Hoofdstuk 2}

\section{BESTUURSKOSTEN}

\section{$\S 2.1$ Inleiding}

Teneinde bestuurskosten te kunnen meten is het noodzakelijk eerst het begrip bestuurskosten aan een nadere analyse te onderwerpen. Deze analyse vormt het centrale thema van dit hoofdstuk.

Bestuurskosten zijn het gevolg van overheidsbesturing. De overheid staat een aantal beleidsinstrumenten ter beschikking. De meest gangbaar geachte overheidsmaatregelen zijn wetgeving, prikkels, voorzieningen en informatie. In de gezondheidszorg is wetgeving het meest gebruikte instrument.

Om inzicht te krijgen in de theoretische benadering van de bestuurskosten is naar aanknopingspunten gezocht binnen de economie. De term bestuurskosten is in de economie echter niet gangbaar. Het meest verwant is nog de zogeheten Nieuwe Institutionele Economie. Hiervan maakt de transactiekostenbenadering deel uit.

$\mathrm{Er}$ is sprake van conceptuele onduidelijkheid omtrent het begrip bestuurskosten. Men spreekt bijvoorbeeld over verborgen beleidskosten, bureaucratiekosten, plankosten, kosten van de bestuurlijke infrastructuur. Er worden veel verschillende termen naast elkaar gehanteerd. De betekenis ervan is weliswaar verwant, maar vaak toch net iets anders. Om hierin enige orde te scheppen zullen de begrippen en omschrijvingen worden geanalyseerd en gerubriceerd. Op grond hiervan zal een eigen definitie worden omschreven.

Na definiëring van de bestuurskosten zijn echter nog niet alle afbakeningsproblemen uit de wereld. Afbakeningsproblemen zijn immers de hoofdoorzaak van het ontbreken van een meting van de bestuurskosten tot dusverre.

De opbouw van dit hoofdstuk is verder als volgt. Paragraaf 2.2 behandelt de besturingsinstrumenten in de gezondheidszorg. In paragraaf 2.3 wordt ingegaan 
op de plaats van de bestuurskosten binnen de economie. In paragraaf 2.4 worden zoveel mogelijk definities en beschrijvingen gepresenteerd, waarna wordt getracht hierin enige systematiek aan te brengen. In paragraaf 2.5 zal een eigen afbakening van de bestuurskosten worden geboden ten behoeve van dit onderzoek. Paragraaf 2.6 handelt over de problemen waarmee de afbakening van bestuurskosten gepaard gaat. In paragraaf 2.7 tenslotte worden de conclusies nog eens kort samengevat.

\section{$\S 2.2$ Besturingsinstrumenten in de gezondheidszorg}

De overheid staan bij de besturing diverse instrumenten ter beschikking. In de Engelstalige literatuur wordt met name Mitnick (1980) beschouwd als een autoriteit op het gebied van de overheidsbesturing. Needham (1983). Balch (1980) en Schultze (1977) hebben eveneens gezaghebbend publicaties op dit terrein geschreven. In Nederland heeft Geelhoed (1983) als eerste een aanzet gegeven tot de instrumentenleer. Daarnaast hebben onder andere Ringeling (1983), Bressers en Klok (1987) en Van der Doelen (1988) aandacht besteed aan dit onderwerp.

In de bestuurskunde worden doorgaans vier categorieën instrumenten van overheidsbesturing onderscheiden. Dit zijn wetgeving, prikkels, voorzieningen en informatie. Strikt genomen is er nog een vijfde instrument: het laissez faire of de non-interventie (Van der Doelen en Klok, 1989). Laissez faire betekent dat de overheid zich terughoudend opstelt en zich onthoudt van inmenging in het particuliere leven. Doorgaans wordt het niet-ingrijpen echter niet tot de instrumenten van overheidsbesturing gerekend, omdat niet sprake is van een uitvoeringsproces. Daarom zal het hier verder buiten beschouwing blijven.

Wetgeving betreft geboden en verboden die dwingend worden opgelegd door de overheid. Wetgeving kan aangeven wat wel en niet is toegestaan. Er is sprake van gebods- of verbodsbepalingen. Een voorbeeld hiervan is de Ziekenfondswet. Deze bepaalt dat iedereen met een inkomen onder een bepaalde grens verplicht is verzekerd. Een ander voorbeeld is de Wet Ziekenhuisvoorzieningen die procedures bevat en bevoegdheden vastlegt op het gebied van de planning van voorzieningen.

Prikkels, of "incentives", moeten stimuleren tot een bepaald gedrag. Dit gaat niet gepaard met dwang, zoals bij voorschriften wel het geval is. Prikkels kunnen positief of negatief zijn. Positieve prikkels zijn bijvoorbeeld subsidies. Negatieve prikkels, zogeheten "disincentives", zijn bijvoorbeeld heffingen. In het geval van positieve prikkels wordt het vertonen van beoogd gedrag beloond. Een voorbeeld zijn de Exploitatie Verlagende Initiatieven. Ziekenhuizen worden beloond wanneer zij bouwkundige aanpassingen aanbrengen die de exploitatiekosten verlagen. In het geval van negatieve prikkels wordt ongewenst gedrag ontmoedigd. Voorbeelden van negatieve prikkels zijn eigen bijdragen (in België "remgelden" genoemd), zoals de medicijnknaak.

Een voorziening, ook wel een faciliteit genoemd, wordt geleverd of bekostigd door de overheid. Vele voorzieningen zijn eigendom van de overheid of staan geheel onder controle van de overheid. Voorzieningen kunnen echter ook door de particuliere sector worden geleverd. In dat geval stelt de overheid een budget ter beschikking waarmee de faciliteit kan worden gerealiseerd. Voorbeelden van overheidsvoorzieningen zijn de basisgezondheidsdienst, de keuringsdiensten en de inspec- 
ties. Voorbeelden van gesubsidieerde particuliere voorzieningen zijn het algemeen maatschappelijk werk en het opbouwwerk.

Informatie is het vierde instrument van overheidsbeïnvloeding. Informatie wordt verstrekt om kennis over te dragen of om voorlichting te geven. Voorbeelden zijn gezondheidsstatistieken AIDS-voorlichting of informatie omtrent de stelselwijziging.

Deze instrumenten kunnen behalve ieder apart ook in combinatie worden gebruikt (Schultze, 1977; Balch, 1980; Rosenthal, Van Schendelen en Ringeling, 1987). De budgettering van ziekenhuizen is hiervan een voorbeeld. De budgettering bestaat immers enerzijds uit een gebod en anderzijds uit een prikkel. Het gebod is het budget dat men niet mag overschrijden. De prikkel is het feit dat een eventueel exploitatie-overschot naar eigen goeddunken mag worden besteed. Een voorkomend tekort moet daarentegen uit eigen middelen worden bijgepast. Beide instrumenten beogen de doelmatigheid te bevorderen.

Een groot deel van het gezondheidszorgbeleid bestaat uit wetgeving. Het aantal wetten is in de loop der jaren explosief gestegen, zoals blijkt uit figuur 2.1. Dit geldt de afgelopen decennia met name voor wetten op het gebied van de financiering en de planning.

Figuur 2.1 Het aantal wetten in de gezondheidszorg door de jaren heen

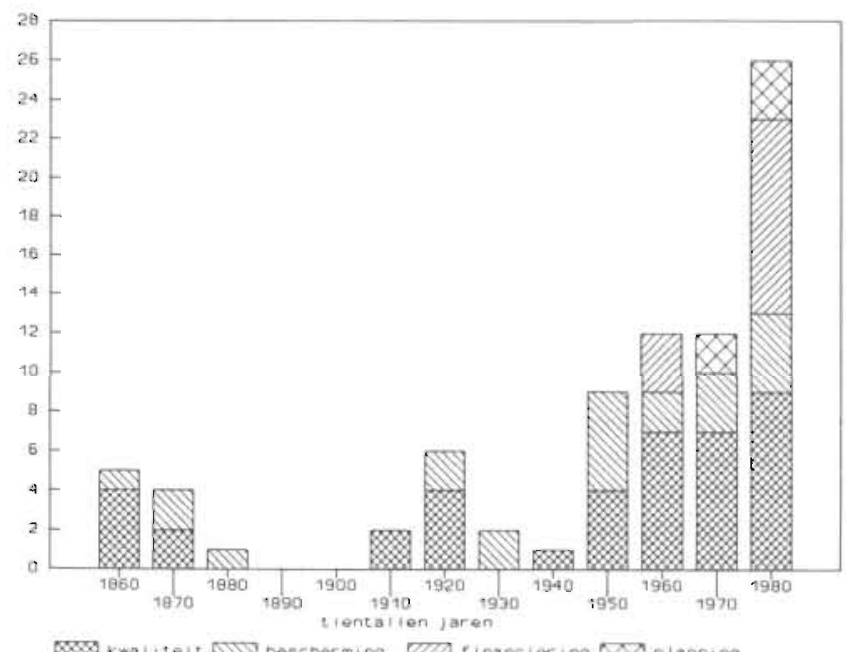

Gebaseerd op: H.C.C.E. Koster, H.D.C. Roscam Abbing. L.F. Markenstein Wet- en regelgeving gezondheidszorg: bestuursinstrumenten Rijksuniversiteit Limburg, 1987 
Aan de hand van een vijtal vragen die Mitnick (1980) van belang acht bij de analyse van "regulation" zal het instrument regulering in de gezondheidszorg nader worden bezien. De vragen die Mitnick hanteert zijn de volgende:

- wie legt regulering op?

- aan wie wordt regulering opgelegd?

- wat is de aard van de activiteiten waarop de regulering van toepassing is?

- waarom wordt regulering opgesteld?

- door middel van welke regulering wordt gestuurd?

De eerste vraag van Mitnick luidt: wie legt de regulering op? In de gezondheidszorg is dit met name de overheid. De overheid heeft in de loop der jaren, maar vooral in de afgelopen decennia, een uitgebreid scala van wet- en regelgeving in de gezondheidszorg ingevoerd (Koster, Roscam Abbing en Markenstein, 1987).

Regulering kan ook afkomstig zijn van maatschappelijke organisaties. Men noemt dit zelfregulering. Een voorbeeld hiervan is de registratie van medisch specialisten. Deze vindt namelijk niet plaats door de overheid, maar door de medische beroepsbeoefenaren zelf (Van der Made en Van Mierlo, 1990). Zij zijn verenigd in de Koninklijke Nederlandse Maatschappij ter bevordering der Geneeskunst. Deelverenigingen, de Landelijke Specialistenvereniging bijvoorbeeld, houden de registraties van medisch specialisten bij.

De tweede vraag van Mitnick betreft de actoren die aan regulering worden onderworpen en luidt: op wie heeft regulering betrekking? De regulering in de gezondheidszorg betreft overheden, verzekeraars, aanbieders van zorg en patiënten.

Van de overheden heeft het rijk aan de gemeenten bijvoorbeeld de uitvoering van het Vestigingsbesluit Huisartsen en de instelling van Basisgezondheidsdiensten opgedragen. Aan de provincies is onder meer de uitvoering van de Wet Ziekenhuisvoorzieningen opgelegd.

Ziekenfondsen en particuliere ziektekostenverzekeraars zijn eveneens onderworpen aan regulering door de overheid. Zij hebben onder meer te maken met de Ziekenfondswet, de Algemene Wet Bijzondere Ziektekosten en sinds kort met de Wet Medefinanciering Oververtegenwoordiging Oudere Ziekenfondsverzekerden, de Wet op de Toegang tot de Ziektekostenverzekering en de Wet Interne Lastenverevening Particuliere ziektekostenverzekeringsbedrijf.

Daarnaast worden de aanbieders van zorg met een grote hoeveelheid regulering geconfronteerd. Dit geldt zowel voor de gezondheidszorginstellingen als voor de individuele beroepsbeoefenaars. Instellingen hebben bijvoorbeeld te maken met de Wet Ziekenhuisvoorzieningen, de Ziekenfondswet, de Algemene Wet Bijzondere Ziektekosten. Behalve deze sectorale wetgeving die uitsluitend van toepassing is op de gezondheidszorgsector, hebben aanbieders van zorg ook te maken met meer generale wetgeving. Generale wetgeving geldt niet specifiek voor de gezondheidszorg, maar voor veel meer sectoren van het maatschappelijk leven, in het meest vergaande geval zelfs voor iedereen. Men kan hierbij denken aan wetgeving op het gebied van de arbeidsomstandigheden, het radio-actief atval, de ondernemingsraad, de ruimtelijke ordening en dergelijke. Deze zijn zowel van toepassing op de gezondheidszorg als op andere sectoren. De individuele hulpverleners hebben onder meer te maken met beroepenwetgeving, vestigingsvoorschriften.

Patiënten hebben onder andere via de Ziekenfondswet te maken met regulering. Krachtens de Ziekenfondswet is iedereen verplicht verzekerd wiens inkomen lager is dan een jaarlijks vastgesteld bedrag. De Ziekenfondswet bepaalt eveneens de inhoud van het verzekeringspakket, de instellingen en beroepsbeoefenaren waarop patiënten een beroep kunnen doen. Daarnaast is wetgeving met betrekking tot patiëntenrechten in voorbereiding. 
De derde vraag betreft de kwestie van de aard van de activiteiten waarop regulering van toepassing is. Op het terrein van de gezondheidszorg stuurt de overheid niet zozeer de directe zorgverlening. De overheid bemoeit zich bijvoorbeeld niet met behandelmethoden. Wel stuurt de overheid in de sfeer van de voorwaarden, zoals:

- de structuur: regeling van spreiding en beschikbaarheid van functies en capaciteiten;

- de prijs: goedkeuring van tarieven en budgetten op grond van wetgeving;

- de financiering: regeling van de financiering door middel van het verzekeringsstelsel;

- de kwaliteit: oplegging van kwaliteitseisen aan instellingen en beroepsbeoefenaren;

- de advisering: de regeling van de adviesstructuur in de gezondheidszorg;

- de patiëntenrechten: garantie van de rechten van patiënten;

- medisch-ethische kwesties: sturing om een zorgvuldige afweging bij discutabele medische ingrepen te garanderen.

De vierde vraag informeert naar de motieven voor regulering. Er zijn tal van motieven om te reguleren. De voornaamste reden voor de overheid om door middel van regulering te sturen is het feit dat de gezondheidszorg, hoewel voor het grootste deel een particuliere sector, wordt beschouwd als een publieke aangelegenheid (Leenen en Roscam Abbing. 1986). Gezondheidszorg is geen individueel goed dat verhandelbaar is op de markt, maar een collectief goed dat moet worden beschermd door de overheid. Het feit dat de gezondheidszorg van oudsher wordt gedomineerd door particuliere instellingen doet hieraan niets af.

Het waarborgen van de kwaliteit is eveneens een reden. Zowel het niveau van het medisch handelen als het afstemmen van het aanbod op de behoefte zijn kwaliteitsvraagstukken (Van der Mijn, 1984).

Bescherming van het individu en van de collectiviteit is van oudsher een reden voor overheidsbesturing. Bescherming tegen besmettelijke ziekten, maar ook patiëntenrechten zijn hiervan een uitvloeisel. Daarnaast bestaat behoefte aan de bescherming van belangen van derden, die bijvoorbeeld in het geval van transplantaties of experimenten gewaarborgd dienen te worden (Leenen en Roscam Abbing, 1986).

De geografische en financieel-economische toegankelijkheid worden eveneens door de overheid geregeld. Om de toegang tot de zorg te garanderen wordt het aanbod gestuurd door voorschriften ten aanzien van het verzekeringsstelsel en de planning van voorzieningen.

Planning beoogt behalve een evenredige spreiding eveneens beheersing van het volume te bereiken.

De beheersing van de kosten van de gezondheidszorg geldt sinds de jaren zeventig als een steeds belangrijker motief voor overheidsingrijpen (Sluyters, 1989). Dit geschiedt zowel door middel van budgettering als door beheersing van het volume, dat wil zeggen het aanbod van bedden en functies.

Tot slot zijn medisch-ethische vraagstukken motieven voor overheidsbesturing. Door de snelle ontwikkeling van de medische technologie heeft dit motief aan betekenis gewonnen.

De vijfde vraag betreft de middelen waarmee wordt gereguleerd. Zoals reeds hiervoor is weergegeven, staan de overheid diverse middelen of instrumenten ter beschikking om te reguleren. Regulering is echter een veel gebruikt instrument van de overheid om invloed uit te oefenen op de gezondheidszorg. Er is een veelheid aan gebods- en verbodsbepalingen in de gezondheidszorg. Zo zijn instellingen en ziekenfondsen gebonden aan een exploitatiebudget, zijn provincies verplicht plannen op allerlei terreinen van de gezondheidszorg op te stellen, moeten 
instellingen een vergunning aanvragen om te mogen investeren in bepaalde dure voorzieningen, zijn instellingen gebonden aan restricties met betrekking tot de bouw of verbouw door middel van het bouwplafond (Lapré en Rutten, 1988). Het middel regulering kan dus op uiteenlopende manieren ingevuld worden.

De manier waarop bestuurskosten worden veroorzaakt zegt nog niets over de de omvang van de bestuurskosten. Hiertoe zullen de bestuurskosten moeten worden gemeten. Voordat echter meting kan plaatsvinden, moet meer bekend zijn over het begrip bestuurskosten en de plaats van de bestuurskosten binnen de economie.

\section{\$2.3 Plaats van bestuurskosten binnen de economie}

Een aanknopingspunt binnen de economie biedt de nieuwe institutionele economie. De nieuwe institutionele economie is in de loop van de twintigste eeuw ontstaan als reactie op de neo-klassieke theorie. De neo-klassieke theorie gaat uit van een markt van volledig vrije mededinging. Op deze markt beschikken alle deelnemers over volledige informatie en maken rationele keuzes. De neoklassieken veronderstellen dat het verzamelen van informatie, het onderhandelen over contracten en het toezien op de naleving van die contracten daarvan geen kosten met zich brengt.

De nieuwe institutionele economie daarentegen gaat ervan uit dat een ideale markt niet bestaat en dat niet rationeel denkende en handelende wezens deelnemen aan een markt, maar opportunisten. Deze opportunisten houden informatie achter of geven informatie misvormd weer, wanneer zij dit gunstig achten voor de uitkomst van onderhandelingen. Ervan uitgaande dat dit voor de tegenpartij ook geldt, verkeren ook zijzelf in onzekerheid omtrent de informatie waarover de tegenpartij beschikt. Om deze onzekerheden zoveel mogelijk de baas te worden, dienen contacten te worden gelegd, transacties te worden gesloten of fusies te worden aangegaan.

Een centraal begrip in de nieuwe institutionele economie zijn de zogeheten "property rights" (aangezien dit begrip verschillend wordt vertaald, bijvoorbeeld door eigendomsrechten of door beschikkingsrechten wordt hier het engelse begrip gehanteerd). De property rights omvatten zowel rechten op materiële zaken (bijvoorbeeld de verkoop of verhuur van een huis), als "menselijke rechten" (bijvoorbeeld het recht om te stemmen, het recht de eigen mening te uiten) (Bokkes, 1989). Property rights zijn geen eigendomsrechten. Het zijn rechten om over een bepaald goed te beschikken. Een werkgever kan beschikken over de arbeid van een werknemer, hij is niet de eigenaar van de werknemer. Individuen ruilen property rights, omdat zij ervan uitgaan dat zij daardoor hun nut vergroten.

Transactiekosten doen zich voor wanneer individuen property rights uitwisselen. Welke property rights worden uitgewisseld en onder welke voorwaarden wordt vastgelegd in een contract. Een eenduidige definitie van transactiekosten bestaat nog niet. Het komt hierop neer dat transactiekosten de kosten zijn van het opstellen van een contract (vantevoren) en het naleven en controleren van een contract (achteraf).

Transactiekosten houden verband met de kosten van het verzamelen van informatie omtrent de uitwisseling van property rights. Toch zijn transactiekosten niet identiek aan informatiekosten. Informatiekosten kunnen optreden zonder dat van 
ruil sprake is. Een onderdeel van de transactiekosten is daarentegen wel de kosten van het verzamelen van informatie omtrent kopers en verkopers (Eggertsson, 1990).

De transactiekostenbenadering beschouwt de onderneming, maar ook de samenleving, als een aaneenschakeling van transacties of contracten. Volgens de transactiekostenbenadering dient een zodanige organisatiestructuur te worden gekozen dat de kosten van de organisatie zo klein mogelijk zijn (Hallwood, 1990).

Overheidsregulering kan een positieve of negatieve invloed hebben op de hoogte van de transactiekosten. Bijvoorbeeld door de stabilisatie van de geldmarkt kan de overheid transactiekosten voor ondernemingen verlagen. Wanneer de overheid handel in bepaalde produkten, bijvoorbeeld heroine, verbiedt, stijgen daarentegen de transactiekosten voor de handelaren (De Vor, 1992).

Een coalitie tussen eigenaren van property rights vervangt de transactiekosten van de transacties van een aantal ondernemingen door de transactiekosten van een geheel van ondernemingen. Een nieuw soort transactiekosten ontstaat dan echter, namelijk de transactiekosten van de vorming en instandhouding van de coalitie.

Een voorbeeld hiervan is de vorming van oliekartels. Deze kartels besparen kosten doordat zij onderlinge prijsafspraken maken en deze opleggen aan de consumenten. Zijzelf maken echter transactiekosten doordat zij de onderlinge afspraken moeten controleren.

Tussen transactiekosten en bestuurskosten bestaat een aantal overeenkomsten en verschillen. Zowel door transacties als door bestuurlijke maatregelen kan verandering van de property rights tot stand komen. Een voorbeeld van luchtvervuiling door een bedrijf kan een en ander verduidelijken. Wanneer de emissie van vervuilde lucht niet aan overheidsregulering is gebonden, moet het betreffende bedrijf de toestemming om vervuiling te mogen produceren "afkopen" bij omwonenden. Wanneer de overheid de emissie van vervuilde lucht aan regulering onderwerpt, hoeft het bedrijf geen contracten af te sluiten met individuele omwonenden. Daarentegen zal de overheid in de bestuurlijke maatregelen eisen stellen aan het bedrijf met betrekking tot de hoeveelheid vervuilde lucht die mag worden geloosd. De naleving van deze maatregelen zal voor het bedrijf transactiekosten met zich brengen (Eggertsson, 1990).

Een tweede overeenkomst is de meetbaarheid. Zowel transactiekosten als bestuurskosten zijn moeilijk te kwantificeren en in geld uit te drukken. Een voordeel van de transactiekosten is dan nog dat informatie omtrent de relatieve transactiekosten voldoende is. Het gaat er immers om een vergelijking te kunnen maken tussen het al dan niet sluiten van een contract of omtrent alternatieve contracten. Hiertoe is informatie met betrekking tot de absolute transactiekosten niet direct noodzakelijk.

Een duidelijk verschil is gelegen in de oorzaken van transactie- en bestuurskosten. Transactiekosten doen zich voor door het afsluiten van contracten. Bestuurskosten worden veroorzaakt door overheidsbesturing.

Een ander verschil betreft de dragers van transactie- en bestuurskosten. Transactiekosten worden gegenereerd door partiulieren die onderling contracten afsluiten. Bestuurskosten worden gemaakt door (lagere) overheden en particulieren die overheidsmaatregelen uitvoeren. 
Tenslotte bestaat verschil ten aanzien van de reden van het maken van transactieen bestuurskosten. Transactiekosten worden gemaakt, omdat degenen die transacties afsluiten, verwachten dat de kosten zonder transacties nog hoger zullen uitvallen. Wel is men vrij om een contract al dan niet af te sluiten. Bestuurskosten als gevolg van geboden en verboden worden gemaakt zonder dat degenen die ze maken een keuze hebben of zij deze kosten wel willen maken. Men is verplicht de overheidsmaatregelen uit te voeren.

De recente literatuur over property rights en over de nieuwe institutionele economie heeft belangrijke bijdragen geleverd aan de economie van de regulering. Door de aandacht te vestigen op de onderneming als een complexe structuur van contracten waardoor transactiekosten worden veroorzaakt, heeft de nieuwe institutionele economie gezorgd voor een toegenomen besef van de ongewenste neveneffecten van overheidsregulering.

Wanneer men de transactekostenbenadering toepast op de gezondheidszorg kan men bijvoorbeeld denken aan de verzekeringswereld. Indien de koepel van de zorgverzekeraars, in het kader van de stelselwijziging contracten afsluit met een hele beroepsgroep zorgaanbieders in plaats van met individuele beroepsbeoefenaren, vervallen de kosten van het afsluiten van vele individuele contracten. De kosten om de koepel in stand te houden komen dan echter op.

Voor deze studie is aansluiting bij de nieuwe institutionele economie van belang om een aanknopingspunt te vinden bij de economie. Er is sprake van verwantschap tussen de theorieën over bestuurskosten en transactiekosten. Doordat echter ook de theorieën omtrent de nieuwe institutionele economie en transactiekosten van recente datum zijn, is ook hier sprake van nog weinig metingen en is het praktische nut voor deze studie beperkt.

\section{\$2.4 Definities van bestuurskosten}

Het antwoord op de vraag "wat zijn bestuurskosten?" is niet gemakkelijk te geven. Er zijn tal van benamingen en definities in omloop van begrippen die allemaal op elkaar lijken, maar toch net niet hetzelfde betekenen. Hierna volgt een tamelijk uitputtend overzicht van de gebruikte benamingen en definities, enigszins gerangschikt naar onderlinge overeenkomsten. Door systematisch aandacht te besteden aan de belangrijkste overeenkomsten en verschillen zal getracht worden enige orde te scheppen in de chaos van begrippen en definities.

In de Miljoenennota van 1982 (1981) wordt gesproken over verborgen beleidskosten. Verborgen beleidskosten zijn kosten die de particuliere sector maakt als gevolg van regulerende overheidsmaatregelen. Ze komen niet tot uitdrukking in de collectieve uitgaven. Dit is bijvoorbeeld het geval wanneer de overheid het gebruik van autogordels verplicht stelt. De kosten hiervan moeten de particulieren zelf dragen.

De Heroverwegingswerkgroep "Wettelijke voorschriften in verband met de economische ontwikkeling" (1981-1982) bezigt eveneens de term verborgen beleidskosten. Maar zij geeft hieraan een bredere interpretatie. In navolging van de definiëring in de Miljoenennota worden de verborgen beleidskosten omschreven als zijnde "lasten die de overheid aan het bedrijfsleven oplegt en die niet worden verantwoord op de Rijksbegroting" (1981-1982, p.6). 
De werkgroep maakt daarbij onderscheid tussen diverse soorten verborgen beleidskosten. Enerzijds doen zich kosten voor bij de uitvoering en handhaving van wettelijke voorschriften. Met name bij de voorbereiding, de uitvoering, het toezicht en het in praktijk brengen van geschillenregelingen is sprake van verborgen beleidskosten. Deze kosten treden uitsluitend op bij overheden. Anderzijds onderscheidt de werkgroep kosten van inachtneming. Zowel produktiehuishoudingen, als gezinnen, als ook overheden komen hiermee in aanraking. Op materieel gebied kan men denken aan kosten van verplichte investeringen, van de exploitatie van deze investeringen en van de verplichte gebruikmaking van goederen of diensten van derden. Op procedureel gebied is sprake van extra kosten door de uitvoering van taken die het gevolg zijn van wettelijke voorschriften en van kapitaalkosten door vertragingen.

Kraan (1982) sluit zich aan bij de door de Heroverwegingswerkgroep gehanteerde benaming. Hij spreekt over de kosten van regulering. Hij maakt onderscheid tussen de uitvoerings- en handhavingskosten die op het overheidsbudget drukken en de kosten, al dan niet afwentelbaar, die in de marktsector moeten worden gemaakt om de regulering in acht te nemen: de zogenaamde verborgen beleidskosten.

Van Duijn (1982) gebruikt de termen verborgen beleidskosten en kosten van handhaving en uitvoering op dezelfde manier als Kraan (1982).

De Beer (1982) geeft aan de term verborgen beleidskosten een meer beperkte interpretatie. Hij omschrijft deze als volgt: "Als de particuliere sector de financiële gevolgen draagt van overheidshandelen komen deze niet of onvolledig in de collectieve lasten tot uitdrukking. Gevolg is dat de zichtbare collectieve lasten een onjuist en onvolledig beeld geven van hetgeen er bij de overheid omgaat" (De Beer, 1982, p.315). Als eenvoudig voorbeeld van verborgen beleidskosten noemt De Beer "het opleggen van een verplichting bij of krachtens de wet, zonder dat daarvoor expliciet enigerlei vergoeding wordt gegeven ..." (1982, p.315). Een moeilijker te traceren vorm van verborgen beleidskosten doet zich voor als de rijksoverheid aan het verstrekken van een al dan niet specifieke uitkering voorwaarden stelt ..." (De Beer, 1982, p.315-316). De Beer beperkt de verborgen beleidskosten tot de lagere overheden.

Kertzman (1983) beperkt zich weer tot de private sector. Hij spreekt over aanpassingskosten. Hij definieert deze als "de kosten die de particuliere sector zich moet getroosten om zich aan de reguleringen aan te passen" (Kraan, 1983, p.244).

De term bureaucratiekosten komt ter sprake in het rapport Heroverweging Binnenlands Bestuur (Heroverweging collectieve uitgaven, 1980-1981). Bureaucratiekosten doen zich voor bij de rijksoverheid wanneer het gaat om het bepalen van de hoogte van doeluitkeringen, zoals de Politie-uitkering of de Onderwijsuitkering "op grond van beleidsfactoren en verfijnde kostencalculaties". Ook gemeenten worden geconfronteerd met bureaucratiekosten, namelijk door het indienen van aanvragen voor doeluitkeringen en het voeren van overleg met het rijk. Hierbij komen nog de personele kosten, die optreden bij de uitvoering van een regeling met de daarbij behorende voorwaarden. Een andere zaak betreft de bureaucratie die nodig is voor de correspondentie en het beheer van uitkeringen die geschieden op basis van aanvragen en declaraties. Hierbij gaat het vaak om relatief kleine bedragen die echter veel werk met zich meebrengen (Heroverweging Collectieve Uitgaven, 1980 1981, p.59). 
In het rapport Heroverwegingen Financiële verhouding Rijk/lagere overheden (1981-1982) worden de bureaucratiekosten op dezelfde manier gehanteerd als in het rapport Heroverweging Binnenlands Bestuur. Zij worden namelijk omschreven als "de kosten die gemoeid zijn met het transporteren van geld van het Rijk naar hetzij een gemeente, provincie of gemeenschappelijke regeling hetzij (een) derde(n), voor zover lagere overheden aan de derde(n) eveneens bijdragen". In het vervolg van het rapport gebruikt de werkgroep de term indirecte kosten (Heroverwegingen Financiële verhouding Rijk/lagere overheden, 1981-1982, p.26).

De werkgroep Heroverweging planprocedures lagere publiekrechtelijke lichamen haakt in haar eindrapport (1983) aan bij de rapporten "Regulering en Deregulering" en "Financiële Verhoudingen Rijk/lagere overheden" waarin respectievelijk de termen verborgen beleidskosten en indirecte kosten worden omschreven als zijnde "niet de kosten van voorzieningen, maar kosten die procedures met zich meebrengen om voorzieningen tot stand te brengen" (werkgroep Heroverweging planprocedures lagere publiekrechtelijke lichamen, 1983, p.4). In het onderhavige rapport worden deze kosten plankosten en planprocedurekosten genoemd. Zij worden omschreven als "niet de kosten van de voorzieningen die men met behulp van een plan beoogt respectievelijk heeft beoogd te realiseren, als wel de kosten die gemoeid zijn met het in acht nemen van de procedurele voorschriften terzake. Het gaat derhalve om een stelsel van aanwijzingen aan lagere overheden op welke wijze een plan tot stand moet worden gebracht" (werkgroep Heroverweging planprocedures, 1983, p.11). Tot deze aanwijzingen rekent de werkgroep: inspraakvoorschriften, termijnen, bezwaar- en beroepsprocedures, onderzoeksvoorschriften, vooroverleg met andere overheden, goedkeuringsbepalingen, het (zich laten) adviseren door gedeconcentreerde diensten, voorschriften hoe en welke belangen in acht genomen moeten worden enz. Deze kosten doen zich voor bij het Rijk, de lagere overheden en derden (zoals gesubsidieerde instellingen, bedrijfsleven en particulieren). Lagere overheden hebben deze kosten steeds als apparaatskosten betiteld, aldus de werkgroep.

De commissie Vonhoff (1985) spreekt in haar eindrapport "Carnavalstocht der planprocedures" over plankosten. Deze zijn het gevolg van de werkbelasting in verband met planverplichtingen: "Planverplichtingen en de daarbij behorende procedures plegen een aanmerkelijke werkbelasting voor de betrokken lagere overheden met zich te brengen. De werkbelasting bij overleg-, advies- en toezichthoudende instanties valt evenmin te onderschatten, om van de werkbelasting i.v.m. bezwaarschriften en beroepsprocedures in dit verband nog maar niet te spreken" (commissie Vonhoff, 1985, p.51).

Moesen en Vanneste (1982) spreken in hun artikel over bureaucratische (over)kosten. Deze doen zich voor door "gebrekkige motivatie, routinematige werkprocedures, overtollig personeel, onbekwaamheid wegens politieke invloeden bij aanwerving en bevorderingen, onvoldoende uitbouw van controles en sancties". Deze "overkosten" zouden te maken hebben met inefficiëntie in de gemeentelijke produktie en organisatie.

Bakker (1983) onderscheidt binnen het begrip bureaucratiekosten enerzijds "alle kosten die met de ambtelijke voorbereiding en uitvoering van het overheidsbeleid zijn gemoeid" en anderzijds "de verspilling van economische waarde, veroorzaakt door de inefficiënte werking van de overheidsbureaucratie: voor een gegeven outputniveau wordt te veel input gebruikt" (p.556). Dit komt overeen met Leibensteins notie van de zogenaamde x-inefficiëntie (zie hiervoor, paragraaf 2.2), 
Op dezelfde manier als Bakker (1983) dat heeft gedaan worden in de Heroverweging Verbetering van de Bedrijfsvoering bij de Overheid (1983), ook wel Zelfbeheer genoemd, bureaucratiekosten omschreven als zijnde kosten die "betrekking hebben op de organisatiestructuren van de rijksdienst: het gaat hier om de efficiency van de bureaucratie als strak hiërarchische organisatievorm". Bureaucratiekosten ontstaan, volgens de werkgroep Zelfbeheer "als gevolg van een natuurlijke tekortkoming van de bureaucratie: het teveel ruimte laten voor het nastreven van privé-doeleinden als versterking van eigen inkomen, domein, gezag. prestige of status" (Heroverweging Verbetering van de Bedrijfsvoering bij de Overheid, 1983, p.22). Deze bureaucratiekosten doen zich ook voor bij grote hiërarchisch gestructureerde particuliere bedrijven, aldus de werkgroep, die hierbij gebruik maakt van Breton en Wintrobe (1982). Men kan dan denken aan bedrijven, zoals Philips, Akzo, Shell en Unilever.

Ook Uit den Bogaard (1984) gebruikt de term bureaucratiekosten. Hij denkt eveneens in termen van inefficiëntie in de produktie "als gevolg van de wijze waarop de organisatie van het aanbod van overheidsgoederen en -diensten is ingericht. Het gaat hier om de (organisatorische) inefficiëntie van de werking van de bureaucratie. Beschouwingen over het bureaucratisch gedrag hebben duidelijk gemaakt dat de bureaucratie een eigen leven heeft met een eigen geldingsdrang die aanleiding geeft tot verspilling" (Uit den Bogaard, 1984, p.281).

Heij heeft in het onderzoek "Een proeve van decentralisatie" (1984) van het Instituut voor Onderzoek van Overheidsuitgaven getracht de planningskosten van sociaalculturele planning te berekenen. Deze planningskosten omschrijft hij als de kosten van de sociaal-culturele planning en programmering, welke worden onderverdeeld in directe (provincie- respectievelijk gemeente-welzijnsambtenaren) en indirecte (overheadkosten) planningskosten. Behalve de provincies en de gemeenten maken individuele instellingen kosten om de planning te volgen.

In het rapport Kosteninventarisatie Uitvoering Besluit Proefgemeenten (1985) hanteert het Onderzoeksbureau I.G.G. het begrip uitvoeringskosten. Deze bestaan uit vier categorieën:

"1. ambtelijk bestede tijd, met aanduiding van het salarisniveau van de betreffende ambtenaren;

2. tijd besteed door bestuursfuctionarissen (burgemeesters, wethouders);

3. tijd besteed door leden van adviesorganen en gemeenteraad (niet-wethouders), uitgesplitst naar niveau van presentiegeld;

4. materiaalkosten en reis- en verblijfskosten;

5. de bedragen die gemoeid zijn met het uitbesteden van werkzaamheden" (Onderzoeksbureau I.G.G., 1985, p.3).

De Commissie Geelhoed introduceert in haar tussenbericht (1982-1983) de begrippen interne en externe beleidslasten, horizontale en vertikale coördinatielasten en kosten van controle, handhaving en rechtsbescherming. Inteme beleidslasten vloeien voort uit de voorbereiding en uitvoering van overheidsregelingen. Zij doen zich voor bij de centrale of decentrale overheid. Exteme beleidslasten zijn het gevolg van het feit dat de burger zich moet houden aan overheidsregelingen. Het voortvloeisel van deze aanpassing mondt uit in kosten in de vorm van belastingen of heffingen. Ook kunnen bepaalde activiteiten duurder of vertraagd worden door overheidsregelingen. Coördinatielasten zijn toe te rekenen aan het feit dat beleid op één gebied of op verschiliende gebieden en binnen éen bestuurslaag dan wel tussen meer bestuurslagen op elkaar moet worden afgestemd. Verder ontstaan kosten door de controle op de naleving van regels, 
handhavingskosten door de toepassing van sancties bij overtredingen en kosten van rechtsbescherming door het uitvoeren van geschillenregelingen.

Waaldijk (1985) gebruikt de term bestuurlijke lasten. Hij doet dit in het kader van een pleidooi voor het aanduiden van de kosten die gepaard gaan met de uitvoering van bepaalde rijksregelingen. Hij maakt onderscheid tussen drie soorten bestuurlijke lasten, namelijk:

a. bestuurlijke lasten die rechtstreeks zijn gemoeid met de uitvoering van de regelgeving, zoals het ontwerpen van uitvoeringsregelingen, het geven van voorlichting, het behandelen van aanvragen voor vergunningen en ontheffingen, de inning van belastingen en heffingen en de uitvoering van in de regeling voorgeschreven feitelijke handelingen;

b. bestuurlijke lasten die niet rechtstreeks voortvloeien uit de uitvoering van de regeling, maar uit in de regeling vervatte procedurele voorschriften, onder andere in verband met de noodzaak van coördinatie met andere bestuursorganen en/of met de afstemming op de uitvoering van andere regelingen, zoals bijvoorbeeld verplichte advisering, inspraak, planning en verslagleggings- en evaluatieverplichtingen;

c. bestuurlijke lasten die zijn gemoeid met het uitoefenen van toezicht op de uitvoering van de regeling (of van daarop gebaseerde gedelegeerde regelgeving) door lagere overheden, zelfstandige bestuursorganen of gedeconcentreerde diensten. Hierbij dient in het bijzonder aandacht te worden geschonken aan de inspecties en aan de lasten die gemoeid kunnen zijn met het beslechten van bestuursgeschillen en met beroepsprocedures.

In de gezondheidszorg blijken eveneens verschillende begrippen en omschrijvingen voor bestuurskosten in omloop te zijn. Zo maakt de commissie Geelhoed in haar eindrapport (1983-1984) gewag van snel stijgende interne besluitvormings- en coördinatielasten in de sector beleid, administratie en beheer van de gezondheidszorg. De Commissie wijst hierbij op het toegenomen aantal "papieren" arbeidsplaatsen.

Hofland en Wilms (1984) gebruiken de term besluitvormingskosten. Hiermee doelen zij op de kosten van beleid, administratie en beheer in de gezondheidszorg.

In het Financieel Overzicht Gezondheidszorg (vanaf 1978-1979) worden de volgende kosten tot de post kosten van beleid, administratie en beheer gerekend: de kosten van ziekenfondsen, de Ziekenfondsraad, de ziektekostenverzekeraars en het gedeelte van de kosten van het ministerie van Welzijn, Volksgezondheid en Cultuur en het Centraal Bureau voor de Statistiek voorzover die kunnen worden toegerekend aan de gezondheidszorg. Ook de kosten van de Provinciale Raden voor de Volksgezondheid worden meegerekend. Verder worden geen organisaties met name genoernd.

In het Financieel Overzicht Zorg (1988-1989) is sprake van de "beleids-, beheersen administratiekosten, zoals die door de overheid, ziekenfondsen, publiekrechtelijke ziektekostenverzekeraars en particuliere ziektekostenverzekeraars worden gemaakt. Tot deze post beleids-, beheers- en administratiekosten worden tevens de kosten van de Ziekenfondsraad, uitvoeringsorganen Algemene Wet Bijzondere Ziektekosten, kosten van premie-inning, College voor Ziekenhuisvoorzieningen, het Centraal Orgaan Tarieven Gezondheidszorg. Nationale Raad voor de Volksgezondheid en de Gezondheidsraad" (p.135). 
De Nationale Raad voor de Volksgezondheid (1984) gebruikt de term kosten van de administratieve infrastructuur. "De administratieve infrastructuur komt vooral tot uitdrukking in:

- het geheel van regelgeving dat voortvloeit uit wetten, verordeningen, richtlijnen en uitvoeringsmaatregelen, met als doel sturing, planning en beheersing van de gezondheidszorgvoorzieningen mogelijk te maken;

- de totale ordening van de regelgeving;

- de individuen, instituten en instellingen die zijn belast met het opzetten van (het geheel van) regelgeving, de uitvoering respectievelijk de controle ervan.

Tot de kosten van de administratieve infrastructuur rekent de Raad al die kosten die verband houden met administratieve (of alleen registratieve) activiteiten ten gevolge van het creëren, opzetten, ordenen, uitvoeren en controleren van regelgeving. In het Financieel Overzicht Gezondheidszorg zijn deze kosten slechts gedeeltelijk zichtbaar gemaakt, namelijk in het hoofdstuk "Beleid, administratie en beheer, ambulancediensten en overige gezondheidszorg" (p.19), aldus de Raad.

Rutten (1986) hanteert de term beleidskosten als synoniem voor de "kosten van beleid, administratie en beheer". Deze doen zich voor door "activiteiten van rijk en organisaties in het veld van de gezondheidszorg, die ais "indirect" kunnen worden gekarakteriseerd" (p.65).

In de Verenigde Staten spreken Himmelstein en Woolhandler over "heatth care administration costs" (1986, p.442). Reinhardt (1991) en de United States General Accounting Office (1991) hanteren ook dit begrip. Zij allen vatten hieronder de gezondheidszorgoverheadkosten van overheden, verzekeraars, ziekenhuis- en verpleeghuisadministraties en zelfstandig gevestigde artsen. Deze kosten doen zich voor als gevolg van het versturen van rekeningen, marketing-activiteiten, het voeren van de boekhouding en institutionele planning. Hieruit spreekt een veel bredere benadering van de bestuurskosten dan in deze studie wordt gehanteerd. Deze bestuurskosten zijn immers zowel het gevolg van interne besturing als van de uitvoering van extern opgelegde overheidsmaatregelen.

Het bovenstaande overzicht biedt een grote variëteit van aan bestuurskosten verwante begrippen en definities. De definities zullen nu nader worden onderzocht door aandacht te besteden aan de belangrijkste relevante kenmerken.

\section{a. Bestuurskosten zijn al dan niet het gevolg van overheidsbesturing.}

In de meeste gevalien wordt een duidelijk verband gelegd tussen overheidsbesturing en het bestaan van bestuurskosten. Op die manier wordt bijvoorbeeld de term verborgen beleidskosten gehanteerd (Miljoenennota, 1981; Heroverwegingswerkgroep "Wettelijke voorschritten in verband met de economische ontwikkeling, 1981-1982; De Beer, 1982; werkgroep Herovenweging planprocedures lagere publiekrechtelijke lichamen, 1983). Ook wordt daarbij soms de relatie weergegeven tussen bestuurskosten en de uitvoering van éen bepaalde maatregel. Dit is bijvoorbeeld het geval bij het gebruik van de term plan- of planningskosten (Commissie Vonhoff, 1985; Heij, 1984) en van de term uitvoeringskosten (Onderzoeksbureau 1.G.G., 1985). Er is dan sprake van een enge interpretatie van de bestuurskosten.

In andere gevallen worden de bestuurskosten breder geinterpreteerd. Met name Himmelstein en Woolhandler $(1986 ; 1991)$ en Reinhardt (1991) verbinden overheidsbesturing niet met het door hen gehanteerde begrip "health care administration costs". Zij leggen daarentegen een verband tussen bestuurskosten en het achterwege blijven van overheidsbesturing. 


\section{b. Bestuurskosten zijn verborgen.}

Een van de kenmerken van de definities van bestuurskosten die regelmatig terugkomt, betreft het feit dat bestuurskosten als zodanig niet op begrotingen of rekeningen voorkomen. Dit wordt treffend geillustreerd door het gebruik van de term verborgen beleidskosten (Miljoenennota, 1981; Heroverwegingswerkgroep "Wettelijke voorschriften in verband met de economische ontwikkeling, 1981-1982; Kraan, 1982; Van Duijn, 1982; De Beer, 1982; Werkgroep Heroverweging planprocedures lagere publiekrechtelijke lichamen, 1983).

\section{c. De dragers van bestuurskosten.}

De definities verschillen ten aanzien van de vraag door wie de bestuurskosten worden gedragen. Sommige definities blijven beperkt tot de bestuurskosten bij de overheid. Dit is het geval waar men de termen plankosten (Hey, 1984; Commissie Vonhoff, 1985) en apparaatskosten (Werkgroep Heroverweging planprocedures lagere publiekrechtelijke lichamen, 1983) hanteert. In andere definities wordt de term bestuurskosten gereserveerd voor de bestuurskosten bij particuliere organisaties, zoals in de Miljoenennota (1982) waar men de term verborgen beleidskosten gebruikt. In weer andere definities dragen zowel de overheid als andere organisaties of individuen bestuurskosten. Dit is het geval bij de Commissie Geelhoed (1982-1983), die hiertoe de termen interne en externe beleidslasten gebruikt.

\section{d. De afbakening van bestuurskosten.}

In sommige publicaties hanteert men een dusdanig brede definitie van bestuurskosten dat investeringen en de produktie van voorzieningen ook tot de bestuurskosten worden gerekend. In andere publicaties wordt aan de term bestuurskosten een meer beperkte interpretatie gegeven. Zo rekent men tot de verborgen beleidskosten (Miljoenennota 1982), de aanpassingskosten (Kertzman, 1983) en de kosten van inachtneming (Heroverwegingswerkgroep "Wettelijke voorschriften in verband met de economische ontwikkeling, 1981-1982) de investeringen die het gevolg zijn van het naleven van wettelijke voorschriften. In het geval van plankosten (Werkgroep Heroverweging planprocedures lagere publiekrechtelijke lichamen, 1983) daarentegen blijven de kosten van voorzieningen buiten beschouwing. Datzelfde geldt voor de kosten van beleid, administratie en beheer (Financieel Overzicht) en de kosten van de bestuurlijke infrastructuur (Nationale Raad voor de Volksgezondheid, 1984), waartoe alleen de kosten van administratieve activiteiten gerekend worden.

\section{e. Bestuurskosten en het beleidsproces.}

In bepaalde publicaties gaat men ervan uit dat bestuurskosten zich gedurende het gehele beleidsproces voordoen. In andere publicaties limiteert men bestuurskosten tot de uitvoering van beleid. Volgens de Commissie Geelhoed (1982-1983) doen bestuurskosten zich voor bij de voorbereiding, de uitvoering, de controle, de handhaving en de beslechting van geschillen. In het geval van plan(procedure)kosten (Werkgroep Heroverweging planprocedures lagere publiekrechtelijke lichamen, 1983; Heij, 1984; Commissie Vonhoff, 1985) en van uitvoeringskosten (Kraan, 1982; Kosteninventarisatie Uitvoering Besluit Proefgemeenten, 1985) beperkt men de bestuurskosten uitdrukkelijk tot de kosten die zich voordoen bij de uitvoering van beleid. 


\begin{tabular}{|c|c|c|c|c|c|c|c|c|}
\hline Auteurs: & Gebruikte term: & $\begin{array}{l}\text { Over- } \\
\text { heid: }\end{array}$ & $\begin{array}{l}\text { Verbor- } \\
\text { gen: }\end{array}$ & $\begin{array}{l}\text { Dra- } \\
\text { gers: }\end{array}$ & $\begin{array}{l}\text { Afbake- } \\
\text { ning: }\end{array}$ & $\begin{array}{l}\text { Beleids: } \\
\text { proces: }\end{array}$ & $\begin{array}{l}\text { Ge- } \\
\text { bruik: }\end{array}$ & $\begin{array}{l}\text { Go- } \\
\text { lwan- } \\
\text { titi- } \\
\text { coerd: }\end{array}$ \\
\hline Miljoenennota & $\begin{array}{l}\text { verborgen beleids- } \\
\text { kosten }\end{array}$ & + & + & $p$ & + & n.v.2. & - & - \\
\hline "Wettvoors." & $\begin{array}{l}\text { verborgen beleids- } \\
\text { kosten }\end{array}$ & + & + & $o+p$ & + & + & - & . \\
\hline Kraan/Duljn & $\begin{array}{l}\text { kosten van regule- } \\
\text { ring }\end{array}$ & + & + & $o+p$ & + & + & - & $\cdot$ \\
\hline De Beer & $\begin{array}{l}\text { verborgen beleids- } \\
\text { kosten }\end{array}$ & + & + & 0 & - & n.v.t. & e & - \\
\hline Kerzman & aanpassingskosten & + & - & $\mathbf{p}$ & + & n.v.t. & e & 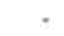 \\
\hline "Binn.Best." & bureaucratiekosten & + & + & 0 & n.v.t. & n.v.t & e & - \\
\hline "Fin Verhoud." & bureaucratiekosten & + & + & o & n.v.t & - & e & - \\
\hline "Planproced." & planprocedurekosten & + & + & $o+p$ & - & n.v.t & $\theta$ & $\cdot$ \\
\hline Cie. Vonhoft & plankosten & + & n.y.t. & $\circ$ & - & - & - & - \\
\hline $\begin{array}{l}\text { Moessen en } \\
\text { Vanneste }\end{array}$ & $\begin{array}{l}\text { buroaucratische } \\
\text { overkosten }\end{array}$ & n.v.t. & - & 0 & n.v.t. & n.v.t. & n & - \\
\hline Bakker & bureaucratiekosten & n.v.t. & - & 0 & n.Y.t. & n.v.t. & $n$ & - \\
\hline Verb. Bedr.v." & buragucratiekosten & n.v.t. & - & $0+p$ & n.v.t. & . & $n$ & - \\
\hline V.d.Bogaard & buraaucratiokosten & n.v.t. & - & 0 & n.v.t. & - & $n$ & - \\
\hline Heij & planningskosten & + & n.v.t. & $0+p$ & n.v.t. & - & e & - \\
\hline I.G.G. & uitvoeringskosten & + & n.v.t. & 0 & + & + & e & + \\
\hline Cir. Geelhoed & beleidslasten & + & n.v.t. & $0+p$ & n.v.e. & + & 6 & - \\
\hline Waaldijk & bestuurlijke lasten & + & n.v.t. & 0 & n.v.t. & + & - & - \\
\hline $\begin{array}{l}\text { Hofland on } \\
\text { Wilms }\end{array}$ & $\begin{array}{l}\text { besluitvormings- } \\
\text { kosten }\end{array}$ & - & n.v.t. & $o+p$ & n.v.t. & n.v.t & - & + \\
\hline $\begin{array}{l}\text { Financieal } \\
\text { Overzicht }\end{array}$ & $\begin{array}{l}\text { kosten van beleid. } \\
\text { administratie en } \\
\text { beheer }\end{array}$ & n.v.t. & n.v.t. & $o+p$ & n.v.t. & n.v.t. & e & + \\
\hline Nationale Faad & $\begin{array}{l}\text { kosten van } \\
\text { administratieve } \\
\text { infrastructuur }\end{array}$ & + & + & $o+p$ & - & + & e & - \\
\hline Rutten & beleidskosten & n.v.t. & n.v.t. & $o+p$ & n.v.t. & n.v.t. & - & - \\
\hline $\begin{array}{l}\text { Himmeistein } \\
\text { e.e. }\end{array}$ & administratiokosten & - & n.v.t. & $o+p$ & n.v.t. & n.v.t. & e & + \\
\hline $\begin{array}{l}\text { overheid: } \\
\text { verborgen: } \\
\text { dragers: } \\
\text { afbakening: } \\
\text { beleidsproces: } \\
\text { gebruik: } \\
\text { gekwantiflceerd: } \\
\text { n.v.t. = hat kenmer }\end{array}$ & \multicolumn{8}{|c|}{ 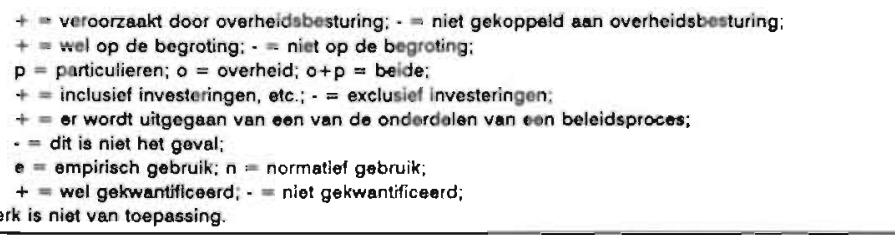 } \\
\hline
\end{tabular}

\section{f. Empirische of normatieve bestuurskosten.}

Tenslotte brengen sommige auteurs een normatief element aan in de definitie van bestuurskosten. Dit is het geval bij het gebruik van de term bureaucratiekosten of bureaucratische overkosten op de manier waarop deze door Moesen en Vanneste (1982), Bakker (1983), de Heroverweging Verbetering van de Bedrijfsvoering bij de 
Overheid (1983) en Uit den Bogaard (1984). Zij leggen een verband tussen bestuurskosten en inefficiëntie respectievelijk verspilling.

Schema 2.1 biedt een systematisch overzicht van de diverse kenmerken en benamingen van bestuurskosten.

Uit het feit dat zoveel verschillende begrippen worden gehanteerd, dat zo weinig consensus bestaat over de betekenis van de term bestuurskosten en dat zo weinig pogingen zijn ondernomen om de bestuurskosten te kwantificeren, kan men concluderen dat bestuurskosten een vaag, breed en moeilijk af te bakenen begrip is. Voor de meting van de bestuurskosten is het echter noodzakelijk een eenduidige afbakening te formuleren.

\section{§2.5 Afbakening en definitie van bestuurskosten}

Zoals gezegd zijn nog nauwelijks pogingen gedaan om bestuurskosten te meten. Veelal blijt het bij beschouwingen. Aangezien het hier wel de bedoeling is de bestuurskosten te meten, zal een eigen definitie worden geformuleerd. Hiertoe zullen de gemeenschappelijke kenmerken van de hiervoor behandelde begrippen het uitgangspunt vormen.

Deze gemeenschappelijke kenmerken waren de volgende. Bestuurskosten zijn al dan niet het gevolg van overheidsbesturing. In deze studie wordt de enge benadering van bestuurskosten gehanteerd. Dit betekent dat bestuurskosten het gevolg zijn van overheidsbesturing. De brede benadering van bestuurskosten houdt in dat ook de kosten van de interne besturing door instellingen en de kosten van besturing die autonoom van overheidsbesturing worden gemaakt.

Bestuurskosten zijn verborgen op begrotingen. Bij de meting van de bestuurskosten zal getracht worden ook inzicht te krijgen in de verborgen beleidskosten.

De dragers van bestuurskosten zijn overheden en particulieren. In deze studie wordt ervan uitgegaan dat bestuurskosten door zowel overheden als particulieren worden gemaakt. In zowel de publiekrechtelijke als particuliere sector worden immers bestuurlijke activiteiten verricht en bestuurlijke maatregelen uitgevoerd en dit brengt bestuurskosten met zich mee. Laat men één van beide kostendragers buiten beschouwing, dan zou sprake zijn van onderschatting van de bestuurskosten.

Investeringen en voorzieningen worden in het algemeen niet tot de bestuurskosten gerekend. In dit onderzoek worden investeringen en voorzieningen uitsluitend tot de bestuurskosten gerekend voor zover zij noodzakelijk zijn voor bestuurlijke activiteiten. De kosten van administratieve voorzieningen, ofwel de bestuurlijke infrastructuur, zoals computers die worden gebruikt bij bestuurlijke activiteiten, worden wel tot de bestuurskosten gerekend. De kosten van voorzieningen die het gevolg zijn van de naleving van bestuurlijke maatregelen, worden echter niet meegerekend. Wanneer bijvoorbeeld in een ziekenhuis als gevolg van een overheidsregeling voorzieningen voor de afvoer van nucleair afval moeten worden gecreëerd, blijven de kosten van deze voorzieningen buiten beschouwing. De grens ligt met andere woorden bij de bestuurlijke activiteiten. Vormen voorzieningen een onderdeel van bestuurlijke activiteiten, dan worden de kosten van deze 
voorzieningen tot de bestuurskosten gerekend. Is geen sprake van bestuurlijke activiteiten, dan blijven de kosten van voorzieningen buiten beschouwing.

Bestuurskosten worden ingedeeld naar onderdelen van een beleidsproces. Is men geinteresseerd in de bestuurskosten die het gevolg zijn van de uitvoering van een bepaalde maatregel, dan ligt onderscheid naar onderdelen in het beleidsproces voor de hand. Uitvoering is immers een onderdeel van het beleidsproces.

Bestuurskosten kunnen empirisch of normatief worden benaderd. Hier wordt het begrip bestuurskosten empirisch ingevuld. Of bepaalde kosten noodzakelijk zijn dan wel duiden op verspilling, blijft buiten beschouwing. Een normatieve invulling van het begrip bestuurskosten zou de complexiteit van de meting van bestuurskosten vergroten, omdat dan criteria nodig zijn om vast te stellen of bepaalde bestuurskosten al dan niet noodzakelijk zijn. Afhankelijk van degene die de criteria opstelt, zal de noodzaak wel of niet aanwezig worden geacht.

Op grond van bovengenoemde overwegingen is gekozen voor de volgende definitie:

bestuurskosten zijn de kosten van de bestuurlijke infrastructuur bij overheden en particulieren die het gevolg zijn van overheidsbesturing in de gezondheidszorg.

Voor zover in deze studie anders vermeld, wordt van de enge benadering uitgegaan.

In schema 2.2 is de enge en brede benadering van bestuurskosten weergegeven.

Schema 2.2 De enge en brede benadering van bestuurskosten

Enge benadering van bestuurskosten:

bestuurskosten zijn de kosten van de bestuurlijke infrastructuur bij overheden en particulieren die het gevolg zijn van overheidsbesturing in de gezondheidszorg.

Brede benadering van bestuurskosten:

bestuurskosten zijn de kosten van de bestuurlijke infrastructuur bij overheden en particulieren die het gevolg zijn van besturing in de gezondheidszorg. Daarnaast behoren zowel de kosten van interne besturing als de kosten die het gevolg zijn van autonome (niet overheids) besturing.

Zoals is gebleken, is afbakening en definiëring van bestuurskosten onmogelijk zonder diverse problemen tegen te komen. Daarom zijn de afwegingen die bij de keuzen zijn gemaakt, weergegeven. Dit wil nog niet zeggen dat de afbakening daarmee probleemloos kan geschieden. Ook hier komt men nog ettelijke problemen tegen.

\section{§2.6 Problemen bij de afbakening}

Een aantal factoren maakt een duidelijke afbakening tussen wat wel en wat niet tot bestuurskosten wordt gerekend, problematisch. Het is vrijwel onmgelijk een scherpe afbakening tot stand te brengen. In de eerste plaats is de begrenzing van de gezondheidszorgsector moeilijk te bepalen. Waar tot voor kort het begrip gezondheidszorg werd gehanteerd, wordt sinds een aantal jaren de term "zorgsector" gebruikt. Dit heeft tot gevolg dat onderscheid tussen de gezondheidszorgsector en de zorgsector, waartoe ook de maatschappelijke dienstverlening wordt 
gerekend, moet worden gemaakt. Soms zijn de grenzen echter niet eenduidig aan te geven.

Ten tweede blijkt uit onderzoek dat bij beleid een zeer groot aantal actoren betrokken is. Bovendien heeft dit aantal de neiging uit te dijen. Ook hier moet men zich afvragen waar men de grens legt. Men zou uit kunnen gaan van de wettekst, maar deze biedt niet altijd uitkomst. Het is niet ongewoon dat de verdere invulling van een procedure aan lagere overheden wordt overgelaten. Deze invulling wordt dan niet vermeld in de wettekst. Het aantal betrokkenen kan ook afhangen van de mate waarin men in een bepaalde regio inspraak en onderling overieg voorstaat. Dan is het aantal actoren plaatsgebonden. Nog ingewikkelder wordt het wanneer bijvoorbeeld banken worden ingeschakeld bij de aanschaf van dure apparatuur. Moet men banken dan rekenen tot de actoren die betrokken zijn bij de beleidsvoering? De enig mogelijke remedie is in deze gevallen duidelijk te expliciteren wie wel en wie niet wordt gerekend tot de direct betrokkenen.

In de derde plaats bestaat geen scherpe grens tussen beleidsvorming en beleidsuitvoering. Beleidsvorming en beleidsuitvoering lopen dikwijls geleidelijk in elkaar over of zelfs door elkaar heen, zodat van een nauwkeurige afbakening geen sprake kan zijn. Een voorbeeld hiervan is de kaderwetgeving. Hierin worden letterlijk kaders vastgelegd, een nadere invulling moet er daarna nog aan gegeven worden. De vraag is of bij deze invulling al sprake is van uitvoering of dat dit nog hoort bij de beleidsvorming. Om dit probleem op te lossen moet men een duidelijk beginpunt aangeven van waaruit men de uitvoering van een bepaalde maatregel en dus ook de meting laat starten.

In de vierde plaats geldt dat het moeilijk is onderscheid te maken tussen activiteiten die het gevolg zijn van de uitvoering van een overheidsmaatregel en activiteiten die kunnen worden toegeschreven aan de interne beleidsvoering of aan autonoom beleid. Enig houvast biedt de wettekst, maar ook deze bevat niet alle maatregelen.

Ten vijfde kan men stellen dat de afbakeningsproblemen in omvang toenemen naarmate het aggregatieniveau waarop de meting plaatsvindt, lager wordt. Indien de meting plaatsvindt op een hoog aggregatieniveau gaat men uit van de kosten van hele instellingen of instanties. Het is dan alleen zaak aan te geven om welke instellingen het gaat. Indien meting plaatsvindt op het niveau van de uitvoering van een maatregel, wordt slechts een deel van de kosten, of van de bestede tijd, van een bepaald personeelslid meegenomen. Van welk deel en van welk personeelslid sprake is, moet dan nader worden bepaald.

Tot slot doen zich toerekeningsproblemen voor wanneer activiteiten niet duidelijk zijn af te bakenen. Dit speelt bijvoorbeeld een rol wanneer een betrokkene niet exact kan aangeven in het kader van welke maatregel hij een bepaalde activiteit heeft ondernomen. Om dit probleem het hoofd te bieden, kan men uitgaan van minimale schatting. Dit houdt in dat men uitsluitend meetelt wat eenduidig kan worden toegerekend aan een bepaalde maatregel. Activiteiten waarbij dit onderscheid niet kan worden gemaakt, blijven buiten beschouwing. Men moet zich dan wel realiseren dat sprake kan zijn van onderschating.

Samenvattend kan men stellen dat het weliswaar mogelijk is onderscheiding aan te brengen, maar dat scherpe grenzen in de praktijk niet of nauwelijks zijn te trekken. Dat zal dan ook wel mede verklaren waarom niemand tot dusver zijn vingers aan de meting van bestuurskosten heeft durven branden. 
Nu afbakening en definiëring hebben plaatsgevonden, wil dat niet zeggen dat daarmee de meetproblemen uit de weg zijn geruimd. De volgende stap is dan ook operationalisering van de bestuurskosten die in de hoofdstukken vijf, zes en zeven zal worden behandeld.

\section{§ 2.7 Samenvatting en conclusies}

Bestuurskosten zijn het gevolg van overheidsbesturing. Om te sturen staan de overheid vier instrumenten ter beschikking, te weten wetgeving, prikkels, voorzieningen en informatie. Het instrument wetgeving lijkt in de gezondheidszorg het meest te worden gebruikt.

Om inzicht in het begrip bestuurskosten te vergroten is gezocht naar aanknopingspunten van de bestuurskosten bij de economie. De Nieuwe Institutionele Economie blijkt de beste ingang te bieden. Een onderdeel hiervan zijn de de transactiekosten. Transactiekosten doen zich voor doordat particulieren contracten afsluiten om "property rights" uit te wisselen.

Inzicht in de afbakening en definiëring van bestuurskosten biedt de economie niet, Hiervoor was de bestudering van voornamelijk rapporten en beleidsnotities noodzakelijk. Dit leverde een veelheid van benamingen en verschillende definities op. Enkele gemeenschappelijke kenmerken zijn de volgende: bestuurskosten zijn al dan niet het gevolg van overheidsbesturing; bestuurskosten zijn verborgen op begrotingen; dragers van bestuurskosten zijn overheden en particulieren; investeringen en andere materiële kosten worden wel of niet meegenomen; in sommige gevallen gaat men uit van de onderdelen van het beleidsproces; de meeste auteurs hanteren een empirische benadering, alleen waar het begrip bureaucratiekosten wordt gebruikt is sprake van een normatieve benadering. Bovendien is geconcludeerd dat kwantificering van de bestuurskosten uitermate zelden heeft plaatsgevonden.

Aangezien het in deze studie wel de bedoeling is dat de bestuurskosten worden gekwantificeerd, zijn de bestuurskosten vervolgens nader gedefinieerd.

Bestuurskosten zijn de kosten van de bestuurlijke infrastructuur bij overheden en particulieren die het gevolg zijn van overheidsbesturing in de gezondheidszorg. In deze studie wordt deze enge benadering van bestuurskosten gehanteerd. In studies waar een brede benadering wordt gehanteerd, worden ook de kosten van de interne besturing en de kosten van autonome (niet-overheids)besturing meegerekend.

Bij de afbakening doet zich een aantal problemen voor. Dit zijn de volgende: de gezondheidszorg is uitgebreid met de maatschappelijke dienstverlening en heet tegenwoordig zorgsector; tussen beleidsvorming en beleidsuitvoering bestaat geen scherp onderscheid; het is niet altijd duidelijk welke actoren wel en welke niet bij de meting moeten worden betrokken; de grens tussen de uitvoering van overheidsbesturing en interne besturing is soms vaag; hoe lager het aggregatieniveau waarop de meting plaatsvindt, des te groter zijn de afbakeningsproblemen; met toerekeningsproblemen moet rekening worden gehouden. 



\section{Hoofdstuk 3}

\section{BESTUURSKOSTEN OP BEGROTINGEN ?}

\section{$\S 3.1$ Inleiding}

In dit hoofdstuk zal worden ingegaan op vraag of de bestuurskosten in de gezondheidszorg zijn terug te vinden op begrotingen. Zoals reeds eerder besproken is "bestuurskosten" geen gangbaar begrip. Naar verwachting zal de post "bestuurskosten" als zodanig dan ook niet gehanteerd worden. Het zal echter wel zo zijn dat volksgezondheid bij overheden een aparte begrotingspost vormt en hiervan maken de bestuurskosten deel uit. De verborgen beleidskosten zullen evenmin als in andere sectoren in de gezondheidszorg op begrotingen voorkomen.

De bestuurskosten die het gevolg zijn van de uitvoering van een bepaalde maatregel zouden van prestatiebegrotingen moeten kunnen worden afgeleid. Prestatiebegrotingen koppelen uitgaven aan een bepaald produkt of prestatie. De uitvoering van een bepaalde maatregel levert immers een prestatie op, zoals een afgegeven vergunning. Met prestatiebegrotingen wordt echter nog slechts sporadisch gewerkt. Toch zijn zelfs de pogingen te komen tot prestatiebegrotingen bruikbaar voor deze studie. Men zal immers op vergelijkbare problemen stuiten als bij de bepaling van de bestuurskosten.

Het in ruimere mate toepassen van de prestatiebegroting kan entoe leiden dat te zijner tijd een provinciaal verpleeghuisplan als prestatie wordt opgevoerd. Aan deze prestatie zou dan moeten zijn gekoppeld hoeveel tijd of geld de totstandbrenging heeft gekost. Tot dusver wordt de prestatiebegroting echter nog slechts op beperkte schaal toegepast en zijn dergelijke gegevens niet voor handen. 
De opbouw van dit hoofdstuk is als volgt. In paragraaf 3.2 wordt onderzocht hoe het komt dat bestuurskosten niet op begrotingen en jaarrekeningen zijn terug te vinden. Paragraaf 3.3 geeft weer waarom de prestatiebegroting ertoe kan bijdragen dat meer bekend wordt over de bestuurskosten van een maatregel. In paragraaf 3.4 worden de conclusies samengevat.

\section{§ 3.2 Bestuurskosten op begrotingen en jaarrekeningen}

Bestuurskosten zijn niet als zodanig op begrotingen of jaarrekeningen terug te vinden. De post "bestuurskosten" bestaat niet. Bovendien wordt een gedeeite van de bestuurskosten door andere organisaties gedragen. Een deel van de bestuurskosten wordt immers niet voor niets de "verborgen beleidskosten" genoemd (zie paragraaf 2.3). Dit betekent echter nog niet dat elke begroting even weinig informatie verschaft over de bestuurskosten. Met name de aard van de gehanteerde begroting is van belang voor het achterhalen van bestuurskosten. Sommige soorten begrotingen kunnen namelijk meer inzicht bieden in de bestuurskosten dan andere.

Eerst zal worden ingegaan op de manier waarop begrotingen kunnen worden opgezet. Hiertoe is het van belang te weten dat bij de totstandkoming van een produkt, analoog aan de systeemtheorie, drie fasen kunnen worden onderscheiden: de input, de throughput en de output (Blommaert en Blommaert, 1988). De input bestaat uit alle middelen die noodzakelijk zijn om een produkt te fabriceren. Hierbij kan men denken aan arbeid, machines, grondstoffen. De throughput is het proces waarmee de middelen worden omgezet in het gewenste eindprodukt. Het gaat hierbij om alle activiteiten die binnen een organisatie of produktieproces verricht worden. De output tenslotte wordt gevormd door de produkten of diensten, die zijn gefabriceerd of geleverd.

Overeenkomstig de drie fasen van het produktieproces wordt ook gesproken over drie soorten begrotingsindelingen. Wanneer de input het uitgangspunt vormt van een begroting, is deze gebaseerd op kostensoorten. Kostensoorten verwijzen naar de aard van de produktiemiddelen. Op de begroting staan in dat geval posten, zoals personeelskosten, afschrijvingskosten, materiële kosten. Ligt het proces ten grondslag aan de begroting, dan zijn de kostenplaatsen terug te vinden op de begroting. Kostenplaatsen zijn de organisatie-eenheden waar de kosten worden gemaakt. Het kan hierbij zowel gaan om afdelingen, zoals personele zaken, de administratie, een beleidsafdeling, als om een projectgroep, zoals een onderzoeksgroep. Tenslotte kan ook de output dienen als uitgangspunt voor de begroting. Men spreekt dan over een begroting gebaseerd op kostendragers. Dit zijn de eindprodukten van de organisatie-eenheden. Kostendragers zijn bijvoorbeeld industriële produkten, een wetenschappelijke publicatie, een ziekenhuisplan. De kosten van de totstandkoming van een ziekenhuisplan zijn de bestuurskosten. Wanneer een organisatie werkt met kostendragers, wil dit zeggen dat bekend is hoeveel kosten ieder produkt heeft veroorzaakt bij diverse afdelingen. Deze kosten worden doorberekend aan het eindprodukt. In het bedrijfsleven is een dergelijke kostprijsberekening noodzakelijk om de kostprijs te kunnen bepalen. Anders zou het ene produkt te duur en het andere te goedkoop op de markt worden gebracht (Blommaent en Blommaert, 1988). Het bovenstaande levert schema 3.1 op. 
Schema 3.1 De relatie tussen de fase in het produktieproces, de begroting en de kostenposten

\begin{tabular}{|c|c|c|c|}
\hline Fase: & $\begin{array}{l}\text { input } \\
\text { middelen }\end{array}$ & $\begin{array}{l}\text { throughput } \\
\text { produktieproces }\end{array}$ & $\begin{array}{l}\text { output } \\
\text { eindprodukt }\end{array}$ \\
\hline $\begin{array}{l}\text { Begroting geba- } \\
\text { seerd op: }\end{array}$ & kostensoorten & kostenplaatsen & kostendragers \\
\hline Kostenposten: & $\begin{array}{l}\text { personele kosten } \\
\text { materiële kosten }\end{array}$ & $\begin{array}{l}\text { personele zaken } \\
\text { administratie }\end{array}$ & $\begin{array}{l}\text { produkt } \\
\text { plan }\end{array}$ \\
\hline $\begin{array}{l}\text { Bijvoorbeeld: zie- } \\
\text { kenhuis }\end{array}$ & $\begin{array}{l}\text { verpleegkundig } \\
\text { personeel } \\
\text { röntgenpersoneel } \\
\text { laboratoriumper- } \\
\text { soneel } \\
\text { enz. }\end{array}$ & $\begin{array}{l}\text { verpleegafdeling } \\
\text { röntgenafdeling } \\
\text { ziekenhuislabora- } \\
\text { torium } \\
\text { enz. }\end{array}$ & $\begin{array}{l}\text { totale kosten be- } \\
\text { steed aan een } \\
\text { patiënt die met } \\
\text { een bepaalde } \\
\text { ziekte in het zie- } \\
\text { kenhuis heeft } \\
\text { gelegen }\end{array}$ \\
\hline
\end{tabular}

In de non-profitsector en met name in de bestuurlijke sector is kostprijsberekening eerder uitzondering dan regel (Van de Kar, 1981; Mol, 1986). Dit komt doordat in de publieke sector gebruikers voor goederen niet of slechts gedeeltelijk hoeven te betalen. De noodzaak om aan de output of de prestaties een prijskaartje te hangen ontbreekt dus. Ook dienen vragers en aanbieders in de marktsector het eens te zijn over de eenheid waarin de output wordt gemeten. Anders vindt geen transactie plaats. Aan deze vereiste is in de publieke sector veelal evenmin voldaan. Een bijkomend gevolg van het ontbreken van een kostprijsberekening is dat het in de publieke sector niet goed mogelijk is het aanbod door middel van de vraag te beïnvloeden wanneer men niet tevreden is over de geleverde diensten. Vaak is de aanbieder monopolist. Dit alles stimuleert niet tot het trachten het inzicht te vergroten in de kosten van de bestuurlijke sector.

De aard van het begrotingsstelsel dat wordt gehanteerd is eveneens van invloed op de mogelijkheid om te komen tot kostprijsberekening van publieke produkten. In de leer der openbare financiën worden vier begrotingsstelsels onderscheiden. Deze stelsels zijn:

a. het verplichtingenstelsel;

Het verplichtingenstelsel houdt in dat op de begroting de bedragen worden opgenomen, waartoe in de begrotingsperiode door de overheid verplichtingen mogen worden aangegaan (contracten mogen worden afgesloten), die op dat moment of later tot werkelijke uitgaven zullen leiden.

b. het stelsel van verkregen rechten;

Het stelsel van verkregen rechten impliceert dat de bedragen op de begroting worden opgevoerd, waartoe crediteuren van de overheid door levering rechten zullen verkrijgen.

c. het kasstelsel;

Het kasstelsel betekent dat op de begroting de bedragen staan die in het begrotingsjaar naar verwachting zullen moeten worden betaald.

d. het stelsel van baten en lasten;

Het stelsel van baten en lasten houdt in dat op de begroting bedragen worden opgenomen die het waardeverbruik (van de goederen) door de overheid in het begrotingsjaar aangeven (Goedhart, 1975; Koopmans en Wellink, 1987). 
Goedhart (1975) geeft het verschil tussen bovengenoemde stelsel weer door middel van het volgende voorbeeld. Stel dat de overheid in jaar 1 goederen bestelt, in jaar 2 die goederen ontvangt, in jaar 3 de goederen betaalt en in jaar 4 de goederen verbruikt. Al naar gelang men stelsel $a, b, c$ of $d$ toepast, worden de betrokken bedragen gebracht ten laste van het dienstjaar (begrotingsjaar) 1, 2, 3 of 4. Welk stelsel gehanteerd wordt, hangt dus af van de vraag welke uitgaven en welke inkomsten aan welke begrotingsperiode worden toegerekend. De kenmerken van de diverse soorten begrotingsstelsels worden weergegeven in schema 3.2 .

\begin{tabular}{l|llll}
\hline Schema 3.2 & Begrotingsstelsels & & \\
\hline Stelsel: & $\begin{array}{l}\text { verplichtingen- } \\
\text { stelsel }\end{array}$ & $\begin{array}{l}\text { stelsel van } \\
\text { verkregen } \\
\text { rechten }\end{array}$ & kasstelsel & $\begin{array}{l}\text { stelsel van } \\
\text { baten en las- } \\
\text { ten }\end{array}$ \\
$\begin{array}{l}\text { Criteri- } \\
\text { um: }\end{array}$ & $\begin{array}{l}\text { tijdstip waarop } \\
\text { contract is afge- }\end{array}$ & $\begin{array}{l}\text { tijdstip waarop } \\
\text { verplichtingen } \\
\text { opeisbaar zijn }\end{array}$ & $\begin{array}{l}\text { voorziene mo- } \\
\text { lijke betaling }\end{array}$ & $\begin{array}{l}\text { waardever- } \\
\text { bruik }\end{array}$ \\
Activiteit: & opdracht & levering & betaling & verbruik \\
\hline
\end{tabular}

In Nederland is de rijksbegroting primair gebaseerd op het kasstelsel. Dit houdt in dat inkomsten en uitgaven worden opgevoerd in het jaar waarin betaling plaatsvindt. Een uitzondering hierop vormt artikel 16, lid 3 van de Comptabiliteitswet (1976). Dit artikel schrijft voor dat van bepaalde begrotingsartikelen vastgelegd dient te worden tot welk maximumbedrag verplichtingen mogen worden aangegaan, die in de toekomst tot uitgaven zullen leiden. Hier is dus sprake van het verplichtingenstelsel (Koopmans en Wellink, 1987).

Het kenmerkende van het kasstelsel is verder dat het bestaat uit de posten "uitgaven" en "inkomsten". Dit houdt in dat op de begroting bijvoorbeeld de aankoop of huur van een produktiemiddel staat vermeld. Indien zou worden gewerkt met "kosten", zou de begroting de afschrijving van het produktiemiddel bevatten.

Kosten in bedrijfseconomische zin hebben betrekking op het feitelijke gebruik van produktiefactoren per periode. Kosten omvatten bijvoorbeeld de afschrijvingen op kapitaalgoederen en de intern doorberekende diensten van andere organisatieonderdelen. Uitgaven daarentegen betreffen de aankoop of de huur van produkten. De consequentie van het hanteren van de begrotingsindeling in uitgaven en inkomsten is dat de overheidsbegroting sterk inputgericht is. Een inputbegroting laat zien dat bepaalde totaalbedragen beschikbaar zijn voor bepaalde zaken, maar geeft geen inzicht in de output ofwel het resultaat. Toch wordt de wenselijkheid van een beter inzicht in de kosten in brede kring onderkend. Door ervan uit te gaan dat overheidsuitgaven bestaan uit het volume van overheidsactiviteiten vermenigvuldigd met de kosten per eenheid overheidsactiviteiten is het verband tussen uitgaven en kosten gelegd. Op basis hiervan heeft het parlement de zogenaamde prestatiebegroting opgenomen in de Comptabiliteitswet, toen deze in 1976 werd gewijzigd. Op de prestatiebegroting zal hierna (in paragraaf 3.3) worden teruggekomen.

De rijksbegroting kent de volgende opbouw. Op grond van de Comptabiliteitswet dient de rijksbegroting te bestaan uit hoofdstukken. leder departement heeft een eigen hoofdstuk. Dit hoofdstuk bevat een inkomsten- en een uitgavendeel. De hoofdstukken bestaan op hun beurt uit afdelingen, paragrafen en artikelen. Deze zijn te beschouwen als kostenplaatsen, omdat daar de kosten daadwerkelijk worden gemaakt. Op de begroting van het ministerie van Welzijn, Volksgezondheid 
en Cultuur komt men bijvoorbeeld tegen: de afdeling volksgezondheid, de onderafdeling gezondheidszorg en het artikel "versterking van de eerste-lijnsverzorging" (Rijksbebegroting 1987, 1986-1987). leder van deze categorieën bevat de kostensoorten "personeel", "materieel" en allerlei subsidies en heffingen.

Door de aard van de rijksbegroting (volgens het kasstelsel en inputgericht) biedt deze weinig inzicht in kosten in het algemeen en in kostendragers, zoals opgestelde plannen of afgegeven vergunningen, in het bijzonder.

Aan het hoofdstuk over het ministerie van Welzijn, Volksgezondheid en Cultuur van de rijksbegroting wordt een bijlage over de zorgsector toegevoegd. Dit is het zogeheten Financieel Overzicht. Het bevat overzichten van de kosten en de produktie van de gezondheidszorg. Deze worden echter niet expliciet aan elkaar gekoppeld. Een afzonderlijk onderdeel in het Financieel Overzicht is het hoofdstuk "kosten van beleid, administratie en beheer". Deze kosten zijn te beschouwen als een onderdeel van de bestuurskosten. In dit hoofdstuk zijn de beheerskosten van de overheid op het gebied van de zorg opgenomen, naast bijvoorbeeld de beheerskosten van verzekeraars. De kosten van beleid, administratie en beheer worden evenmin gekoppeld aan de uitvoering van bepaalde maatregelen. Op de bestuurskosten in het Financieel Overzicht wordt in hoofdstuk 5 ingegaan.

Op grond van de Provinciale comptabiliteitsvoorschriften (1979) krachtens de Provinciewet is de provinciebegroting gebaseerd op het stelsel van baten en lasten. Dit houdt in dat de uitgaven en inkomsten behoren tot het dienstjaar waarop zij betrekking hebben. Het gevolg hiervan is dat bijvoorbeeld de afschrijvingen op duurzame kapitaalgoederen als uitgaven tot uitdrukking worden gebracht.

De provinciebegroting is onderverdeeld in drie diensten: een gewone dienst (met voornamelijk lopende kosten, zoals personeelkosten), een kapitaaldienst (met materiële kosten, zoals investeringen) en een verdeeldienst (met door te sleutelen kosten). De gewone dienst en de kapitaaldienst zijn opgebouwd uit verschillende onderwerpen van provinciale zorg, die zijn ingedeeld in tien hoofdfuncties. Hoofdfuncties zijn bijvoorbeeld: algemeen bestuur, waterhuishouding, economische en agrarische zaken, welzijn. De hoofdfuncties bestaan uit diverse inkomstencategorieën (bijvoorbeeld inkomsten uit het provinciefonds, leges, winsten uit belastingopbrengsten) en uitgavencategorieën (zoals salarissen en sociale lasten). In het hoofdstuk welzijn is de paragraaf volksgezondheid opgenomen, die onder andere bestaat uit de posten "apparaatskosten", "onderzoek", "adviserende organen", "sociaal-medische aangelegenheden", "ziekenhuizen en andere voorzieningen".

Voor de apparaatskosten ("de kosten van het inzetten van personeel, het gebruik van niet direct toerekenbare geïnvesteerde produktiemiddelen en goederen en diensten van derden voor de uitvoering van provinciale taken", Provinciale Comptabiliteitsvoorschriften, 1979, p.95) geldt een aparte bepaling. Deze dienen namelijk via verdeelsleutels toegerekend te worden aan functies. Zo krijgt bijvoorbeeld de afdeling welzijn als het ware een rekening voor de huisvesting, bibliotheekfaciliteiten, drukkerijwerkzaamheden. Hiertoe is een indeling gemaakt naar hulpkostenplaatsen ofwel ondersteunende kostenplaatsen (huisvesting, bibliotheek, reproduktie, enzovoort), hoofdkostenplaatsen (beleidsafdelingen, zoals de afdeling welzijn) en kostendragers (provinciaal bureau welzijnsplanning, bejaardenzorg, diensten voor derden).

Ten opzichte van de rijksbegroting geeft de provinciebegroting aanzienlijk meer informatie inzake kosten en baten. Dit komt onder andere doordat de kostenplaatsen en kostensoorten nader uitgesplitst zijn. Er vindt echter evenmin als in de rijksbegroting toerekening plaats van kosten aan maatregelen

Wanneer men de bestuurskosten voor de gezondheidszorg op provinciaal niveau wil afleiden van de provinciebegroting, kan men hooguit de totale kosten van het 
bureau volksgezondheid bepalen. De bestuurskosten van een maatregel kunnen niet aan de hand van de provinciebegroting worden bepaald.

De gemeentebegroting geeft eenzelfde beeld te zien als de provinciebegroting. De Gemeentelijke comptabiliteitsvoorschriften krachtens de gemeentewet zijn in 1982 gewijzigd en in 1985 in werking getreden. Ook de gemeentebegroting is gebaseerd op het steisel van baten en lasten.

De indeling van de begroting in een gewone, een kapitaal- en een verdeeldienst komt eveneens overeen met die van de provinciebegroting. Verder bestaat de gemeentebegroting uit tien hoofdfuncties, 85 functies en ettelijke subfuncties, categorieën en subcategorieën. Zo bevat de hoofdfunctie volksgezondheid bijvoorbeeld de functie "algemeen beheer" (omschreven als "de kosten van het bestuursapparaat"), de uitgavencategorie "salarissen en sociale lasten" en de inkomstencategorie "overdrachten van het rijk", aldus de Gemeentelijke comptabiliteitsvoorschriften (1982). Verder bevat de post Volksgezondheid de functies "verpleeginrichtingen", "ambulancevervoer".

De bestuurskosten van gemeenten zijn dus af te leiden uit de functie "algemeen

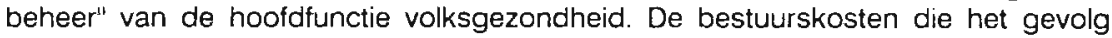
zijn van de uitvoering van een bepaalde maatregel zijn ook hier niet te achterhalen aan de hand van de begroting.

Een bijkomend probleem voor kosten van overheden zijn de dubbeltellingen. Wanneer bijvoorbeeld provincies of gemeenten subsidies of bijdragen ontvangen van het rijk om bepaalde maatregelen uit te voeren, wordt eenzelfde bedrag tweemaal uitgegeven: eenmaal door het rijk aan de provincies of gemeenten en eenmaal door de provincies of gemeenten bij de eigenlijke vitvoering. Wanneer men met andere woorden kosten bij overheden inventariseert aan de hand van begrotingen, dient men met dubbeltellingen rekening te houden.

Bestuurskosten worden niet alleen gedragen door de overheid, maar ook door particulieren. In de gezondheidszorg kan worden gedacht aan instellingen, zoals ziekenhuizen of verpleeghuizen en individuele beroepsbeoefenaren. Dit roept de vraag op in hoeverre de bestuurskosten van deze organisaties zichtbaar worden gemaakt. Op de begroting van overheden ontbreekt de post "verborgen beleidskosten" in ieder geval.

De begrotingen van instellingen bevatten onder andere de kostenpost "algemeen personeel". Hiertoe behoren onder meer de kosten van de directie, de administratie, het organisatiepersoneel. Van deze rekeningen krijgt men enigszins een indruk van de hoogte van de bestuurskosten van individuele gezondheidszorginstellingen. Het Nationaal Ziekenhuisinstituut en het Centraal Bureau voor de Statistiek verzamelen en presenteren de gegevens van de gehele intramurale sector. Hieruit kan men afleiden hoe hoog de bestuurskosten van alle gezondheidszorginstellingen tesamen zijn.

Voor de particuliere verzekeraars verzamelt de Stichting KLOZ Informatiesysteem Gezondheidszorg en voor de ziekenfondsen het Landelijk Informatiesysteem Ziekenfondsen kostenoverzichten voor de gehele sector.

Over de bestuurskosten van individuele beroepsbeoefenaren worden geen statistieken bijgehouden. Hoe groot de omvang daarvan is, blijt dus onbekend (zie hierover verder hoofdstuk 5).

Voor het onderzoek is de aard van de door de overheden gehanteerde begrotingen in zoverre van belang dat deze hierdoor meer of minder informatie bieden inzake de bestuurskosten. Het kasstelsel, het verplichtingenstelsel en het stelsel 
van verkregen rechten werken met inkomsten en uitgaven. Van kostenposten is dus geen sprake.

De rijksbegroting biedt geen inzicht in de bestuurskosten doordat deze is gebaseerd op het kasstelsel. De begroting van het ministerie van Welzijn, Volksgezondheid en Cultuur vormt hierop een gunstige uitzondering door de toevoeging van het Financieel Overzicht. In dit overzicht worden de bestuurskosten van onder meer de overheid en verzekeraars vermeld. Hoe hoog de bestuurskosten per maatregel of per project zijn, kan men echter niet uit het overzicht afleiden.

De provincie- en gemeentebegroting verschaffen dankzij het gehanteerde stelsel van baten en lasten informatie over de directe en de toegerekende kosten van de afdelingen volksgezondheid van provincie en gemeente. Ook hier blijven de verborgen beleidskosten van particulieren buiten beschouwing. Van toerekening van de kosten aan de uitvoering van bepaalde maatregelen is bij provincie- en gemeentebegroting evenmin sprake.

\section{§ 3.3 Bestuurskosten en de prestatiebegroting}

Is men geïnteresseerd in de bestuurskosten per uit te voeren activiteit, zullen deze kosten aan activiteiten toegerekend moeten worden. Indien op ruimere schaal met zogeheten prestatiebegrotingen zou worden gewerkt, zouden de bestuurskosten bekend zijn. In een prestatiebegroting worden "de in fysieke eenheden uitgedrukte prestaties, die in de begrotingsperiode naar verwachting zullen worden gerealiseerd, gekoppeld aan de kosten (of de uitgaven) die met die prestaties zullen zijn gemoeid" (Van de Kar, 1981, p.103). Een beleidsmaatregel is te beschouwen als een prestatie. Dit houdt in dat men bij het bepalen van de kosten van prestaties op vergelijkbare problemen stuit als bij de meting van de bestuurskosten.

Een kostendrager is een eenheid waaraan de voor de produktie gemaakte of te maken kosten worden toegerekend. In de commerciële sector heet dit de kostprijs van een produkt. Aangezien de bestuurskosten de kosten zijn die het gevolg zijn van de uitvoering van bestuurlijke maatregelen, is een maatregel te beschouwen als een kostendrager.

Een aantal redenen pleit voor de invoering van een prestatiebegroting. Enerzijds vergroot deze het inzicht in de omvang en de kosten van de produktie. De relatie tussen de produkten en de kosten worden immers zichtbaar gemaakt. Anderzijds kan de zij de doelmatigheid van het te voeren beleid bevorderen door de expliciete koppeling van kosten aan prestaties.

Met het oog hierop heeft het parlement bij de wijziging van de Comptabiliteitswet in 1976 besloten de prestatiebegroting in te voeren. Dit is gebeurd in artikel 4 lid 4 van deze wet. Hierin staat dat het de bedoeling is dat "bij elk daarvoor in aanmerking komend hoofdstuk van de begroting van uitgaven een bijlage word gevoegd waarin met betrekking tot de uitgaven, waarvoor dit mogelijk en van belang is, gegevens worden verstrekt omtrent de prestaties, die het resultaat zijn van de activiteiten, waarop die uitgaven betrekking hebben en omtrent de met die prestaties verband houdende middelen" (Comptabiliteitswet, 1976, p.7-8). Deze bijlage wordt in de begrotingshoofdstukken steeds "bijlage $V$ " genoemd.

De Comptabiliteitswet geeft aan welke gegevens noodzakelijk zijn, namelijk:

- een korte omschrijving van de taak van het organisatie-onderdeel;

- een omschrijving van de prestaties;

- de aantallen prestaties; 
- de kosten per prestatie-eenheid;

- de uitgaven voorkomende in het betreffende onderdeel van de begroting;

- een toelichting op belangrijke verschillen tussen de kosten en de geraamde uitgaven.

Voordat men prestatie-eenheden kan introduceren, moet eerst duidelijk zijn welke kostendragers als prestatie-eenheden kunnen dienen. Zowel tussenprodukten (activiteiten) als eindprodukten (prestaties) kunnen als kostendrager dienen. Van de $\operatorname{Kar}$ (1981) onderscheidt drie soorten kostendragers, afhankelijk van het soort indicator dat men kiest. Deze kostendragers zijn:

1. de activiteiten in het produktieproces;

Men gaat hierbij uit van de procesindicator. Deze beschrijft bepaalde produktieve handelingen of een bepaald intermediair- of halfprodukt. Toegepast op de be. stuurskosten wordt bijvoorbeeld een onderdeel bij de totstandkoming van een plan gemeten. Hierbij kan men denken aan een inventarisatie van de aanwezige beddencapaciteit in de regio die het plan omvat.

2. de eigenlijke prestaties of geleverde eindprodukten;

De prestatie-indicator is het vitgangspunt. De prestatie wordt gezien als een produkt dat gereed is om op een "markt" te worden aangeboden. Voorbeelden zijn een afgegeven vergunning, een plan, enzovoort. Bestuurskosten, die het gevolg zijn van de totstandkoming van een plan of het verlenen van een vergunning, geven met andere woorden de bestuurskosten van een prestatie weer. Deze soort kostendrager wordt toegepast bij de bepaling van de bestuurskosten van een bepaalde beleidsmaatregel.

3. de uiteindelijke effecten;

Hier gaat men uit van de effectindicator. Gekeken wordt dan niet alleen naar de kwantiteit van het produkt, maar ook naar de effectiviteit. Er wordt een waarde toegekend aan het produkt. Men beoordeelt de invloed die het produkt heeft gehad. Een voorbeeld hiervan is de uiteindelijke gezondheidstoestand van mensen nadat een ziekenhuisplan in werking is getreden.

Heeft men eenmaal de kostendragers bepaald, kan men overgaan tot het vaststellen van prestatie-eenheden. Prestatie-eenheden dienen aan een aantal criteria te voldoen (Handleiding Prestatiebegroting, 1982).

1. prestaties zijn het resultaat van de activiteiten van een organisatie en moeten daarvan een duidelijk beeld geven;

Toegepast op de bestuurskosten zou men kunnen stellen dat de prestatie-eenheid een indruk moet geven van de gevolgen van de uitvoering van een bepaalde maatregel. Het heeft bijvoorbeeld weinig zin de hoeveelheid tijd die nodig is voor de inventarisatie van het aantal aanwezige bedden te beschouwen als zijnde representatief voor het werk van een afdeling die plannen opstelt. Daartoe kan men beter de tijd meten die daadwerkelijk aan de opstelling van een plan is besteed.

\section{2. prestaties moeten kwantificeerbaar zijn;}

Kwantificeerbaar wil zeggen in een eenheid meetbaar. Voor de bestuurskosten betekent dit bijvoorbeeld dat de output op een of andere wijze geteld moet kunnen worden. Dit kan zijn door de bestede tijd te meten. Met name in de dienstverlenende sector is het niet ongebruikelijk dat prestaties geen fysieke belichaming kennen. Dit geldt vooral voor bestuurlijke activiteiten, zoals het verlenen van advies of het geven van voorlichting. Dit probleem doet zich niet voor waar het gaat om bijvoorbeeld stadsreiniging, parkeerwachters. 


\section{3. prestaties moeten in voldoende mate homogeen zijn;}

Homogeen wil zeggen dat de prestaties gelijksoortig moeten zijn. Voor de bestuurskosten is dit van belang wanneer men de bestuurskosten van een maatregel door een aantal instanties zou willen vergelijken. In de dienstverlenende sector worden veelsoortige prestaties geleverd. Daardoor wordt de vergelijkbaarheid bemoeilijkt. Het blijkt lastig te komen tot homogene eenheden. Een voorbeeld van een op het oog homogene, maar in werkelijkheid heterogene eenheid is het aantal kilometers aangelegde weg. Deze eenheid had het ministerie van Verkeer \& Waterstaat als prestatie-eenheid gekozen. De grote verschillen in bodembesteldheid bleken echter het aantal kilometers weg als prestatie-eenheid ongeschikt te maken.

Sinds in 1978 de prestatiebegroting voor het eerst aan de rijksbegroting is toegevoegd wordt bij de meeste departementen nog slechts van een klein gedeelte van de prestaties de kosten geraamd (Hazeu, 1980; Van de Kar, 1980; Boorsma, 1981; Hofland en Van Niekerk, 1985; Schild, 1985; Koopmans en Wellink, 1987). Het toerekenen van de gemaakte kosten aan een prestatie-eenheid blijkt problematisch. Doordat de overheidsbegroting inputgericht is (zie paragraaf 3.2) zijn wel inkomsten- en uitgavengegevens beschikbaar, maar geen gegevens omtrent kosten en baten. Men zoekt dan toevlucht tot de weergave van outputgegevens zonder kostentoerekening. Voorbeelden hiervan zijn aantallen afgestudeerden, verzorgden, patiënten.

Concluderend kan men stellen, dat de prestatiebegroting om twee redenen samenhangt met de bestuurskosten. Wanneer vaker gewerkt zou worden met prestatiebegrotingen zou meer bekend zijn omtrent de geraamde bestuurskosten. Afgegeven vergunningen of opgestelde plannen zijn immers prestaties. Aan de hand van de in de prestatiebegrotingen geraamde kosten zou men de bestuurskosten kunnen bepalen. Aangezien echter nog lang niet op alle terreinen met prestatiebegrotingen wordt gewerkt, is dit vooralsnog niet mogelijk. Bovendien zorgt de overeenkomst tussen prestatiebegroting en bestuurskosten ervoor dat de opstellings- respectievelijk meetproblemen vergelijkbaar zullen zijn. De meest voorkomende problemen zijn: het kwantificeren van onzichtbare prestaties, het vinden van gelijksoortige prestatie-eenheden, het toerekenen van kosten aan prestaties en het vinden van geschikte gegevens.

Enigszins verwant aan artikel 4 is artikel 15 van de Comptabiliteitswet (1976). Dit schrijft voor dat kostenramingen worden toegevoegd aan beleidsmaatregelen die worden voorgesteld. Deze eis geldt voor alle voorgenomen beleidsvoorstellen. Dat wil zeggen dat dit niet alleen van toepassing is op wetsontwerpen, maar ook op nota's. Wanneer beleidsvoornemens kunnen leiden tot hogere of lagere inkomsten of uitgaven voor het rijk dient dit uitdrukkelijk te worden aangegeven. Hiertoe is zelf́s een standaardformulier beschikbaar, geheten "Overzicht van de financiële gevolgen voor de rijksbegroting".

Le Coq (1982) heeft geïnventariseerd in hoeverre artikel 15 wordt nageleefd. Zij kwam tot de conclusie dat slechts twee van de 79 onderzochte stukken voldeden aan de eisen die in de wet worden gesteld omtrent de te verstrekken financiële informatie.

In 1985 werd dan ook expliciet door de Vaste Commissie voor Economische Zaken geconcludeerd dat vaak niet aan artikel 15 werd voldaan. Toen is voorgesteld dat het standaardformlier moest worden gevoegd bij ieder voorstel dat in behandeling is. Zonder formlier zal het voorstel niet worden behandeld. 
Onderzoek van de Algemene Rekenkamer (1987-1988) naar de kwaliteit van de financiële informatie bij 97 aan de Tweede Kamer (tussen 1977 en 1987) aangeboden wetsvoorstellen leverde het volgende op. Van de 97 onderzochte voorstellen ontbrak bij bijna de helft (41) financiële informatie. Van de overige (56) bevatte slechts de helft (19) voldoende informatie. Voor de rest (37) werd de informatie matig geacht.

Er blijkt dus niet genoeg aandacht te worden besteed aan de financiële consequenties van beleidsvoorstellen. Volgens de Rekenkamer is "de kwaliteit van de informatie in de memorie van toelichting bij een wetsvoorstel niet zodanig dat de Tweede Kamer zich daarmee in voldoende mate een oordeel kan vormen over de financiële merites van het desbetreffende wetsvoorstel" (1987-1988, p.33). De reden hiervoor kan zijn dat men geen gegevens beschikbaar heeft of geen schatting kan maken van de financiële gevolgen. Een andere reden zou kunnen zijn dat de financiële conseqenties vanuit politiek oogpunt beter niet bekend kunnen zijn. Welke de reden hiervoor ook mag zijn, ook hier blijkt dat de gehanteerde begrotingsstelsels niet geschikt zijn om de gewenste informatie te leveren.

\section{§3.4 Samenvatting en conclusies}

De bestuurskosten zijn niet terug te vinden op de rijksbegroting. Deze is gebaseerd op het kasstelsel, dat uitgaat van inkomsten en uitgaven en niet van kosten. Het Financieel Overzicht vormt hierop een uitzondering. De provincie- en gemeentebegroting zijn gebaseerd op het stelsel van baten en lasten. Hierdoor vindt toerekening plaats van kosten aan uitvoerende afdelingen, dus ook aan de afdeling volksgezondheid. De gezamenlijke rekeningen van gezondheidszorginstellingen van het Nationaal Ziekenhuisinstituut bevatten onder meer de categorie "algemeen personeel", waartoe onder andere de directie, de administratie en het organisatiepersoneel behoren.

Krachtens de Comptabiliteitswet wordt van de departementen verwacht dat zij, waar mogelijk, prestatiebegrotingen opstellen. Prestatiebegrotingen bevatten een raming van de beoogde prestaties met de daartoe benodigde middelen. Tot op heden wordt de prestatiebegroting door de departementen nog slechts summier toegepast. Wanneer de prestatiebegroting wel al op alle maatregelen zou worden toegepast, zouden de bestuurskosten van afzonderlijke beleidsmaatregelen bekend zijn. Dit is evenwel niet het geval en daarom zal men zelf deze kosten moeten inventariseren. Evaluatie van de uitvoering van artikel 15 van de Comptabiliteitswet laat ook een gebrek aan financiële gegevens zien. Krachtens dit artikel zou aan ieder beleidsvoorstel een toelichting omtrent de verwachte financiële consequenties moeten worden toegevoegd. Dit gebeurt echter slechts bij de helft van alle voorstellen. Dit houdt in dat over de andere helft van de voorstellen wordt beslist zonder kennis van de financiële conseqenties. De eindconclusie luidt dan ook dat de bestuurskosten niet als zodanig zijn terug te vinden op begrotingen en rekeningen. Wie dus geïnteresseerd is in de hoogte van bestuurskosten zal deze zelf moeten meten. 


\section{METING VAN BESTUURSKOSTEN}

\section{$\$ 4.1$ Inleiding}

Bestuurskosten kunnen niet zonder meer worden afgeleid van begrotingen of rekeningen. Zoals hierboven vermeld impliceert dit dat wie is geinteresseerd in de hoogte van de bestuurskosten, genoodzaakt is deze zelf te meten.

Onderzoeken waarin bestuurskosten worden gekwantificeerd, zijn schaars. Slechts in enkele gevallen heeft men hiertoe een poging ondernomen. Een voorbeeld hiervan vormt het onderzoek naar de "uitvoeringskosten van de welzijnsplanning voor gemeenten" door het Onderzoeksbureau I.G.G. (1985; 1986). Helaas heeft dit bureau zich beperkt tot de inventarisatie van de totale kosten van de gehele welzijnsplanning. De kosten van de uitvoering van het Besluit Proefgemeenten heeft het bureau niet bepaald. Als reden hiervan wordt aangegeven dat de werkzaamheden ten behoeve van welzijnsplanning moeilijk te scheiden zijn. Een ander voorbeeld is het rapport van de United States General Accounting Office (1991). In dit rapport worden de "administration costs" gemeten. In het Financieel Overzicht worden de "kosten van beleid, administratie en beheer" weergegeven. Hierin blijven de bestuurskosten van instellingen en individuele beroepsbeoefenaren, de zogeheten verborgen beleidskosten, buiten beschouwing.

In dit hoofdstuk wordt weergegeven hoe de bestuurskosten kunnen worden gemeten. In de volgende hoofstukken komt aan de orde voor welke methoden is gekozen.

De opbouw van dit hoofdstuk is als volgt. In paragraaf 4.2 wordt ingegaan op de methodologische criteria waaraan de meting dient te voldoen. Paragraaf 4.3 
behandelt welke dataverzamelingsmethoden denkbaar zijn om de bestuurskosten te meten. In paragraaf 4.4 komen de aggregatieniveaus en de meeteenheden van de meting van bestuurskosten aan de orde. In paragraaf 4.5 wordt uiteen gezet hoe de meting van de bestuurskosten in de gezondheidszorg zal plaatsvinden. Tot slot wordt in paragraaf 4.6 een samenvatting van dit hoofdstuk gegeven.

\section{§4.2 Methodologische criteria}

Een meting moet aan een aantal methodologische voorwaarden voldoen. In de literatuur omtrent sociaal-wetenschappelijke onderzoeksmethoden (Segers, 1977; Cook en Campbell, 1979; De Groot, 1981; Swanborn, 1982; Van Vught en Van Doorn, 1983 en vele anderen) maakt men doorgaans onderscheid tussen validiteit, betrouwbaarheid en generaliseerbaarheid.

De validiteit, ook wel geldigheid of "internal validity" genoemd, houdt in dat een meetmethode inderdaad meet wat men ermee beoogt te meten. Er bestaan allerlei soorten validiteit, bijvoorbeeld de face-validiteit, de criterium-validiteit en de begripsvaliditeit. Face-validiteit houdt in dat de meetmethode op het eerste gezicht meet wat men beoogt te meten. De criterium-validiteit zegt iets over de voorspellende waarde van een meetmethode (De Groot, 1981). Voor dit onderzoek is met name de begripsvaliditeit of "construct validity" relevant. Begripsvaliditeit houdt in dat de operationalisatie van een theoretisch concept zodanig is dat het gehele begrip zo goed mogelijk wordt gedekt (Yin, 1984). Voor deze studie betekent dit dat de operationalisering van het begrip bestuurskosten zodanig is dat hieronder datgene wordt begrepen dat men ermee beoogt te bevatten. De begripsvaliditeit kan worden bevorderd door hetzelfde begrip op verschillende manieren te meten. Voor het meten van de bestuurskosten betekent dit dat niet slechts wordt volstaan met bijvoorbeeld het meten van de bestede tijd als gevolg van de uitvoering van een bepaalde maatregel. Een beschrijving van het hele proces biedt een nuttige aanvulling op de meting. Het begrip bestuurskosten wordt zodoende op twee manieren benaderd.

Een aparte validiteitskwestie is het probleem van de causale toerekening. Yin (1987) hanteert hiervoor overigens eveneens het begrip interne validiteit. Hij merkt op dat dit alleen geldt voor verklarend of causale onderzoeken en niet voor beschrijvende of verkennende onderzoeken. Voor dit onderzoek gaat het om de vraag of bepaalde bestuurskosten inderdaad aan de uitvoering van een concrete overheidsmaatregel kunnen worden tegeschreven.

Betrouwbaarheid, ook wel objectiviteit of "reliability" genoemd, is de mate waarin een meetmethode bij herhaalde meting een stabiel resultaat oplevert (Segers, 1977; Swanborn, 1991). De betrouwbaarheid van het onderzoek kan worden vergroot wanneer de onderzoeker werkt met een nauwkeurig verslag van alle activiteiten en bevindingen. Bovendien is het van belang een databank aan te leggen, waarin alle gegevens systematisch zijn opgeslagen en terug te vinden voor een buitenstaander (Yin, 1984). Voor dit onderzoek is het van belang de meting systematisch te beschrijven. Een andere onderzoeker moet in staat zijn iedere stap te herhalen, zonder dat dit van invloed is op de resultaten. Dit betekent dat een volledige en duidelijke verslaglegging een voorwaarde is voor een betrouwbaar onderzoek.

Een ander betrouwbaarheidsprobleem betreft het cijfermateriaal waarvan gebruik wordt gemaakt. Indien de cijfers uit verschillende bronnen afkomstig zijn, wanneer de bronnen twijfelachtig zijn, in het geval dat gegevens ontbreken of indien men 
voor de gegevensverzameling afhankelijk is van direct betrokkenen, kan de betrouwbaarheid van het cijfermateriaal worden geschaad.

Generaliseerbaarheid of "external validity" houdt in dat de meetresultaten van een onderzoek van toepassing verklaard kunnen worden op bijvoorbeeld een andere populatie, een andere tijd of een andere omgeving (Van Giessen, 1980). Survey- en ander kwantitatief onderzoek zijn gebaseerd op statistische generalisatie. De resultaten worden op grond van uitgebreid cijfermateriaal statistisch bewerkt en van toepassing verklaard op grotere onderzoekspopulaties (Patton, 1982). Voor dit onderzoek is generalisatie niet relevant. De cases zijn niet onderzocht of geselecteerd op representativiteit. Het gaat in deze studie vooral om de toepassing van alternatieve methoden.

Samengevat zijn de methodologische voorwaarden die relevant zijn voor de meting weergegeven in schema 4.1.

Schema 4.1 Methodologische criteria die relevant zijn voor de meting van bestuurskosten

\begin{tabular}{|c|c|}
\hline Criteria: & Relevantie: \\
\hline validiteit & $\begin{array}{l}\text { bestuurskosten worden daadwerkelijk gemeten } \\
\text { aandacht besteden aan causale toerekening }\end{array}$ \\
\hline betrouwbaarheid & $\begin{array}{l}\text { systematische beschrijving van de meting } \\
\text { betrouwbaar cijfermateriaal }\end{array}$ \\
\hline generaliseerbaarheid & is niet van toepassing \\
\hline
\end{tabular}

In de hoofdstukken 5 tot en met 7 wordt de meting van de bestuurskosten geëvalueerd aan de hand van bovengenoemde criteria.

\section{§4.3 Aggregatieniveaus en meeteenheden}

Het aggregatieniveau is de hoogte waarop de meting plaats vindt. Bij een hoog aggregatieniveau wordt niet gekeken naar de bestuurskosten van afzonderlijke maatregelen, maar naar de bestuurskosten van de hele sector. Bij een laag aggregatieniveau wordt wel gekeken naar de bestuurskosten van een maatregel.

De meeteenheid is de maat die wordt gekozen om datgene dat wordt gemeten in uit te drukken. Bestuurskosten kunnen in geld worden uitgedrukt, maar ook andere eenheden, zoals tijd, zijn denkbaar.

De bepaling van de totale bestuurskosten van de gezondheidszorg vindt op het hoogste aggregatieniveau plaats. Het aggregatieniveau is het geheel van organen in de gezondheidszorgsector. Een voordeel van een dergelijk hoog aggregatieniveau is dat men een overzicht kan geven van de toestand en de ontwikkeling van de totale bestuurskosten van de gehele sector. Een ander voordeel is dat de gegevens reeds gedeeltelijk voor handen zijn. Een nadeel is dat deze bepaling minder gedetailleerd is. Een ander nadeel is dat geen eenduidige verklaring kan worden gegeven voor een bepaalde stijging of daling van de bestuurskosten. Hiervoor vinden teveel ontwikkelingen tegelijkertijd plaats. 
De bestuurskosten die het gevolg zijn van de uitvoering van een bepaalde maatregel worden op een laag aggregatieniveau gemeten. Het niveau is een concrete bestuursmaatregel. Afhankelijk van de gekozen manier van dataverzameling is ook dan nog verschil in aggregatieniveau mogelijk. Ten eerste kan de meting een totale uitkomst over een maatregel opleveren. Dit heeft als voordeel dat deze meting eenvoudiger is uit te voeren dan een gedetailleerde meting. De meting wordt immers niet toegespitst op afzonderlijke actoren, maar op het geheel van actoren. Een nadeel is dat deze manier van meten minder specifieke resultaten oplevert.

Ten tweede kan de meting gegevens opleveren die zijn uitgesplitst naar diverse actoren. Een voordeel van een dergelijk laag aggregatieniveau is dat duidelijk wordt hoeveel bestuurskosten exact gemoeid zijn met de uitvoering van deze betreffende maatregel en deze cijfers kunnen worden meegenomen bij de afweging van de betreffende maatregel. Een ander voordeel is het feit dat naar voren komt welke activiteiten en welke actoren bij de uitvoering van de maatregel komen kijken door de uitgebreide beschrijving hiervan. Een nadeel is dat de meting relatief veel tijd kost, doordat het hele proces gevolgd moet worden. Een ander nadeel is dat de vergelijkbaarheid van de uitkomsten klein is. De omstandigheden kunnen immers dusdanig specifiek zijn, dat de uitkomsten van meting van bijvoorbeeld dezelfde maatregel in andere provincies niet te vergelijken zijn.

De bestuurskosten kan men in diverse eenheden uitdrukken. De volgende eenheden zijn denkbaar.

De bestuurskosten kan men in de eerste plaats uitdrukken in geld. In het Financieel Overzicht is dit het geval. Dit geldt ook voor andere bronnen, zoals het Centraal Bureau voor de Statistiek en het Nationaal Ziekenhuisinstituut. Het voordeel van deze eenheid is de relatieve uniformiteit. In principe zijn alle bronnen waarin bestuurskosten in geld worden uitgedrukt, bruikbaar. Anderzijds is een nadeel dat veelvuldig gebruik van eenzelfde eenheid, zoals geld, ten onrechte de schijn opwerpt van eenduidigheid. Ook al wordt bijvoorbeeld in het Financieel Overzicht veel in geld uitgedrukt, dan wil dit nog niet zeggen dat daardoor alle posten zonder meer bij elkaar opgeteld of vergeleken kunnen worden. Onduidelijk kan zijn welke kosten men wel en welke men niet meerekent, waardoor dubbeltellingen kunnen voorkomen. Verder is niet altijd duidelijk of men rekening houdt met prijs- of volume-indexen, die kunnen voorkomen dat autonome veranderingen in de waarde van geld van invloed zijn op een tijdreeks.

In de tweede plaats is het mogelijk de bestuurskosten uit te drukken in aantallen formatieplaatsen. Het aantal formatieplaatsten geeft immers een indicatie van de bestede kosten. Een voordeel van het gebruik van formatieplaatsen is dat men met name in jaarverslagen vaak aantallen formatieplaatsen tegenkomt als meeteenheid. Een nadeel is dat salarissen in hoogte kunnen verschillen, zodat de vergelijkbaarheid niet optimaal is.

De bestuurskosten kan men verder uitdrukken in aantallen geleverde beleidsprestaties per tjdseenheid. Een nadeel is dat deze eenheid alleen geschikt is in geval van een homogene produktie. Het klassieke voorbeeld hiervan is het aantal gelegde bakstenen. In de dienstverlenende sector is evenwel een homogene produktie zeldzaam. Hierbij kan men denken aan produkten, zoals beoordeelde subsidieaanvragen, verstrekte adviezen. In deze gevallen kan niet gewerkt worden met het aantal produkten per tijdseenheid. Het kan immers zo zijn dat het beoordelen van verschillende aanvragen van eenzelfde subsidie meer of minder tijd en dus geld kost. De beoordeelde aanvragen van eenzelfde subsidie zijn dus geen homogeen produkt. Voor de bestuurskosten in de gezondheidszorg geldt eveneens dat deze 
normaliter geen homogene produkten opleveren. Zo zal de ene provincie zal meer of minder tijd nodig hebben voor het opstellen van een ziekenhuisplan, bijvoorbeeld afhankelijk van het feit dat men bedden mag uitdelen of schrappen.

Verder kan de bestede tijd worden gehanteerd als meeteenheid. Het voordeel van deze eenheid is dat deze gemakkelijker toepasbaar is dan het aantal geleverde produkten. In gevallen van heterogene produktie is de bestede tijd een alternatief voor het aantal geleverde produkten per tijdseenheid. Het uitgangspunt van deze eenheid is de direct bestede tijd aan een bepaalde activiteit. Hierbij dient te worden uitgegaan van de werkelijk bestede tijd en niet van de beschikbare tijd. Indien men de beschikbare tijd hanteert, wordt nog niet duidelijk hoeveel tijd in werkelijkheid aan een bepaalde activiteit wordt besteed. De bestede tijd kan als eenheid worden gebruikt om de bestuurskosten uit te drukken. Deze meeteenheid is vrij moeilijk toe te passen, omdat men afhankelijk is van de medewerking van de betrokken uitvoerders. Een voordeel is echter dat het de meest directe meeteenheid is.

Bovendien kunnen de verrichte activiteiten worden geanalyseerd. Wanneer meting van de bestede tijd niet mogelijk is, kan men de verrichte activiteiten als meeteenheid hanteren. Dit houdt in dat nagegaan wordt welke handelingen voortvloeien uit de uitvoering van bepaalde taken bijvoorbeeld aan de hand van een wettelijk vastgelegde procedure. Een overzicht van deze activiteiten biedt een indicatie van de bestuurskosten. Het voordeel van deze eenheid is dat het eenvoudiger is om deze meting uit te voeren dan het inventariseren van de bestede tijd. Een nadeel is het feit dat de meting globalere gegevens oplevert dan de meting van de bestede tijd. Wanneer beleidsmakers of onderzoekers echter alleen behoefte hebben aan globale gegevens, hoeft dit laatste geen nadeel te zijn.

Daarnaast kan men uitgaan van de doorooptijd als eenheid om de bestuurskosten van een beleidsmaatregel uit te drukken. Door na te gaan hoeveel tijd is verstreken tussen het begin en het einde van een procedure bepaalt men de doorlooptijd. Een voordeel van deze meting is de eenvoud waarmee deze uitgevoerd kan worden. Ook hier geldt dat het nadeel van deze eenheid is dat het meetresultaat globaler is dan bij een meting van de bestede tijd. Hier speelt echter eveneens de behoefte van onderzoekers of beleidsmakers een rol bij de vraag of globalere meetresultaten een voor- of een nadeel betekenen.

Tenslotte kan men de bestuurskosten uitdrukken in het aantal actoren dat bij de uitvoering van een beleidsmaatregel is betrokken. Het voordeel van deze eenheid is dat deze gemakkelijk te meten is. Een nadeel is dat de afbakening van welke actoren men meerekent en welke niet problematisch kan zijn. Een ander nadeel is dat het aantal actoren slechts een indicatie geeft van de bestuurskosten.

In schema 4.2 worden de mogelijke meeteenheden weergegeven. 
Schema 4.2 Mogelijke meeteenheden van bestuurskosten

geld

aantallen formatieplaatsen

aantal produkten per tijdseenheid

bestede tijd

verrichte activiteiten

doorlooptijd

aantal betrokken actoren

\section{\$4.4 Mogelijke dataverzamelingsmethoden}

Bij de bepaling van de bestuurskosten in de gezondheidszorg kan het Financieel Overzicht als uitgangspunt worden gekozen. Aangezien in het Financieel Overzicht echter slechts een deel van de bestuurskosten wordt weergegeven, zijn aanvullingen noodzakelijk. In het Financieel Overzicht wordt namelijk geen rekening gehouden met de zogenoemde verborgen beleidskosten bij instellingen in de gezondheidszorg. Wil men inzicht krijgen in de bestuurskosten, is additioneel cijfermateriaal gewenst.

In het Financieel Overzicht wordt gebruik gemaakt van secundair cijfermateriaal. Bijvoorbeeld het Centraal Bureau voor de Statistiek, het Nationaal Ziekenhuisinstituut, het Kontaktorgaan Landelijke Organisaties van Ziektekostenverzekeraars en vele andere bronnen leveren kostengegevens. Het probleem hierbij is de afstemming en de betrouwbaarheid van de gegevens. Niet iedereen rekent immers steeds hetzelfde tot bepaalde kostenposten. Verder is vaak niet duidelijk hoe de dataverzameling heeft plaatsgevonden. Aanvullingen op de gegevens van het Financieel Overzicht zijn te vinden in publicaties van dezelfde instanties die de gegevens leveren, zoals het Centraal Bureau voor de Statistiek. Bij het zoeken van aanvullingen doen zich overigens weer dezelfde afstemmingsproblemen voor.

In de Verenigde Staten hebben Woolhandler en Himmelstein (1986; 1991) voor gegevens over de "health care administration costs" eveneens gebruik gemaakt van statistisch materiaal van derden. De United States General Accounting Office (1991) heeft voor datzelfde doel materiaal van derden geanalyseerd. Dit heeft men aangevuld met gegevens verkregen door eigen inventarisaties aan de hand van interviews.

In de bovengenoemde Amerikaanse publicaties wordt echter uitgegaan van de brede benadering van bestuurskosten. Hierbij worden ook de kosten van de interne besturing en de kosten van de autonome besturing meegerekend. Bepaling van de enge benadering van de bestuurskosten, zoals in deze studie de bedoeling is, vergt de meting van prestaties van overheden en particulieren. Zoals in hoofdstuk 3 naar voren is gekomen, is inventarisatie van prestaties van de overheid door de overheid zelf niet gebruikelijk. Doorgaans gaat de overheid er vanuit dat de input een indicatie geeft van de output. Als reden hiervoor wordt aangevoerd dat de output in de vorm van abstracte voorzieningen of dienstverlening niet te meten 
valt of dat de gegevens die nodig zijn om de output te meten niet beschikbaar zijn. De input is echter geen nauwkeurige indicator van de output.

Derden die onderzoek verrichten naar prestaties van de overheid richten zich ook wel eens op de productiviteit van de overheid. Productiviteit is het aantal produkten of prestaties, dat per impliciete of expliciete tijdseenheid wordt geleverd. Hierop zijn diverse onderzoeken gericht.

Muckler (1982) geeft aan hoe in het algemeen, dus niet alleen bij de overheid, de productiviteit kan worden gemeten. Hij ziet daartoe drie manieren.

1. rechtstreeks, gebaseerd op de output;

Dit houdt in dat de direct geproduceerde produkten worden geteld. In gevallen waarin sprake is van een duidelijke output levert dit in beginsel weinig problemen op. Het klassieke voorbeeld is dat van de metselaar. Men telt het aantal bakstenen dat hij per uur, of een andere tijdseenheid, legt. Wanneer deze aantallen ook nog automatisch door middel van een of ander instrument geteld zouden kunnen worden, is het eenvoudig grote hoeveelheden relatief objectieve data te verzamelen.

Er rijzen echter volgens Muckler minstens drie problemen. Ten eerste levert het meeste werk niet zulke duidelijk af te bakenen eenheden output op. Dit is bijvoorbeeld het geval bij toezichthoudende en beleidsfuncties. Ten tweede geldt voor het meeste werk dat de output niet zo gemakkelijk te tellen is als gevolg van het feit dat de output niet onmiddellijk zichtbaar is. Kwantitatieve metingen kunnen dan wellicht worden aangevuld met kwalitatieve gegevens. Waar het proces van lange duur is, bijvoorbeeld in het geval van onderzoek en onderwijs, kan het jaren duren voordat een goede beoordeling van de output mogelijk is. Vaak wordt dan maar het tussenprodukt in plaats van het uiteindelijke resultaat gemeten. Dit houdt in dat men bijvoorbeeld het aantal publicaties of het aantal citaten meet en niet de uiteindelijke uitwerking van bepaalde publicaties. Van de Kar (1981) raadt deze werkwijze eveneens aan. Overigens is dit punt van een andere orde dan het vorige. Muckler gaat hier uit van de outcome, ofwel de uitwerking die een bepaald produkt heeft. In het geval van de metselaar zou dit bijvoorbeeld betrekking kunnen hebben op de "levensduur" van het bouwwerk. Ten derde is vaak sprake van weerzin jegens de meting van verrichtingen. In het algemeen is men geneigd prestatiemetingen zoveel mogelijk te vermijden.

\section{2. gebaseerd op verslagen van de werknemers zelf;}

Dit houdt in dat de werknemers zelf bijhouden wat zij doen en hoeveel zij geproduceerd hebben. Het is eenvoudig om een productiviteitsmeting gebaseerd op verslagen van werknemers zelf als meetmethode af te wijzen door te attenderen op het subjectieve en in het voordeel van de werknemers werkende karakter ervan. Onderzoek heeft volgens Muckler uitgewezen dat de mate van accuratesse afhankelijk is van het soort werk dat men verricht en van het soort beoordelingen dat gevraagd wordt. Hij concludeert dat de nauwkeurigheid afneemt naarmate de gevraagde beoordeling kwantitatiever is. In bepaalde sectoren wordt de zogenoemde werkagenda op grote schaal gebruikt. Hierin houden werknemers bij welke activiteiten zij verrichten. Wanneer zou worden bewezen dat deze agenda's redelijk betrouwbaar zijn, lijken zil volgens Muckler een goedkope bron van ruwe productiviteitscijfers.

\section{3. gebaseerd op observaties;}

In dit geval wordt de productiviteit berekend aan de hand van observaties door individuen of teams van observatoren. Deze vorm van productiviteitsmeting heeft een slechte naam. Het is alom bekend, aldus Muckler, dat observaties tijdens het werk van invloed zijn op de verrichtingen. Dit is al waargenomen tijdens de 
onderzoeken in de Hawthorne-fabriek in de Verenigde Staten in de jaren twintig. Het feit dat men meet, blijkt datgene wat men beoogt te meten te beïnvloeden. Het geldt met name voor metingen die bedoeld zijn om standaarden te ontwikkelen. Het is de bedoeling om naderhand de productiviteit van de werknemers aan deze standaarden te toetsen.

Hartley, Brecht, Pagerey en anderen (1977) hebben ten eerste een inventarisatie gemaakt van de onderzoeken die zijn gedaan naar subjectieve schattingen van de tijdsbesteding door kantoorpersoneel. Zij komen tot andere conclusies en aanbevelingen dan Muckler (1982). Uit hun overzicht komt naar voren dat werknemers in het algemeen de tijd overschatten die zij besteden aan "belangrijke activiteiten", terwijl zij "persoonlijke tijd" onderschatten. Verder is gebleken dat de nauwkeurigheid van de schatting van werknemer tot werknemer grote verschillen vertoonde.

Ten tweede hebben zij ook zelf onderzoek verricht naar de tijdsbesteding van werknemers. Hierbij is hen, evenals Muckler (1982), gebleken dat werknemers bijna altijd met grote weerzin de hoeveelheid tijd die zij aan diverse taken besteden, kwantificeren. De werknemers voerden aan dat het werk zo vaak van dag tot dag en van maand tot maand verschilde dat daardoor het antwoord nooit een goede weergave zou zijn. Verder betoogden zij dat zij over hun werk nooit dachten in termen van bestede tijd. Alleen na herhaald aandringen lukte het de onderzoekers de werknemers zover te krijgen dat zij een schatting maakten van de hoeveelheid tijd die zij besteden aan hun belangrijkste activiteiten. Sommige werknemers weigerden dan nog. Toen de onderzoekers zichzelf de vraag van de tijdsbesteding voorlegden, zagen zij de moeilijkheden van de ondervraagden. Kantoorwerk is immers een mengeling van allerlei karweitjes die niet onmiddellijk op elkaar volgen, die door elkaar lopen, die worden onderbroken.

Ten derde hebben Hartley, Brecht, Pagerey en anderen drie methoden op de betrouwbaarheid onderzocht. Deze methoden zijn de volgende.

1. een activiteitencodeer-systeem voor de observatie van werknemers;

Hiermee observeerde een buitenstaander de werknemers en hield voor iedere 30 seconden aan de hand van een lijst bij welke activiteiten zij verrichtten. Om de betrouwbaarheid te waarborgen observeerden vaak twee onderzoekers dezelfde personen.

2. een kaartenbak-systeem;

De kaartenbak bevatte alle mogelijke activiteiten met daarbij een instructie van de tijd die meegerekend moest worden. De werknemers moesten zelf de kaarten invullen.

3. een vragenlijst;

Op de vragenlijst stonden alle mogelijke activiteiten vermeld. De werknemers werd gevraagd een schatting te geven van de relatieve tijd die zij aan iedere activiteit besteedden. De relatieve tijd hield in een bepaald percentage van een dag.

Bij het beoordelen van de betrouwbaarheid hanteerden Hartley, Brecht, Pagerey en anderen de observatie-methode als controle voor de twee andere methodes. Zij gingen er dus, in tegenstelling tot Muckler (1982), vanuit dat observeren een betrouwbare methode is. Na diverse statistische bewerkingen is gebleken dat de relatieve schatting door de werknemers beter overeenkwam met de geobserveerde tijd dan de absolute schatting. Dit kwam volgens de onderzoekers overeen met eerder onderzoek. Bovendien was dit ook eerder gebleken uit interviews. Hartley, Brecht, Pagerey en anderen raden dan ook aan om indien het van belang is zeer nauwkeurig de tijdsbesteding te weten, te werken met observaties.

Hatry (1972) is in zijn onderzoek naar produktiviteitsmeting van lokale dienstverlenende instanties niet veel verder gekomen dan de inventarisatie van concrete en tastbare activiteiten met een duidelijk zichtbare output. Hij heeft bijvoorbeeld de 
produktiviteit van de vuilnisophaaldienst bepaald aan de hand van het aantal tonnen opgehaald huisvuil, van ziekenhuizen aan de hand van het aantal patientendagen, van de politie aan de hand van het aantal uren dat men patrouilleerde, het aantal oproepen dat men kreeg en het aantal misdaden dat men onderzocht. Hij beoogde de produktiviteit van een aantal jaren met elkaar te vergelijken.

In Nederland is de produktie van de dienstverlenende sector en met name van de overheid sedert enkele decennia meer in de belangstelling gekomen. De invoering van de prestatiebegroting in de Comptabiliteitswet van 1976 (zie paragraaf 3.3) heeft ervoor gezorgd dat departementen niet langer kunnen volstaan met informatie over de input via de begroting. In het vervolg moet aan de input ook de output gekoppeld worden. Over de manier waarop de kosten van prestaties moeten worden gemeten, wordt weinig uitsluitsel gegeven. In de Handleiding Prestatiebegroting (1982) wordt alleen vermeld dat "gezien de aard van het produktieproces bij de overheid de kostentoerekening dikwijls zal zijn gebaseerd op de aan de produktie te besteden of bestede tijd" (p.18). Verder wordt geadviseerd een bepaalde vorm van tijdverantwoording toe te passen in verband met de kostentoerekening. De andere kosten, zoals indirecte personeelskosten, overhead, huisvestingskosten, zouden vervolgens gekoppeld kunnen worden aan de directe personeelskosten.

Het Onderzoeksbureau I.G.G. heeft in de rapporten "Kosteninventarisatie uitvoering besluit proefgemeenten" $(1985 ; 1986)$ de kosten geïnventariseerd in het kader van de welzijnsplanning door gemeenten. Doordat kosten van planwerkzaamheden als gevolg van het Besluit Proefgemeenten blijkbaar niet te scheiden waren van de kosten van andere planningswerkzaamheden, heeft men de totale kosten van welzijnsplanning gemeten. Hiertoe is aan alle betrokken ambtenaren en bestuursfunctionarissen gevraagd een vragenlijst in te vullen over de bestede tijd. Deze gegevens zijn aangevuld met de materiaalkosten en reis- en verblijfkosten. Die bleken evenwel slechts 20 procent van de totale kosten uit te maken. In het tussenrapport (1985) wordt een aantal kanttekeningen geplaatst. Zo is geconstateerd dat in sommige gevallen niet de werkelijk bestede tijd, maar de ambtelijke capaciteit is ingevuld. Verder is het onderzoeksbureau ervan uitgegaan dat de ondervraagden enigszins hebben overdreven bij het invullen. Dit is echter moeilijk na te gaan. Bovendien heeft het bureau geconstateerd, dat de antwoorden minder betrouwbaar werden naarmate meer tijd was verstreken sinds de te onderzoeken werkzaamheden waren verricht.

Hermans (1985) heeft in haar onderzoek naar een butgetteringseenheid voor een bacteriologisch ziekenhuislaboratorium de laboratoriummedewerkers laten tijdschrijven. Hiertoe werden zij geacht alle handelingen die zij verrichten te noteren en de benodigde tijd te registreren. Deze resultaten zijn gecombineerd met de geklokte tijden bij het uitvoeren van diverse laboratoriumtests. Ook hier bestond de indruk dat de aanwezigheid van iemand met een stopwatch het arbeidstempo beïnvloedde. Door de resultaten van beide registratiemethoden aan elkaar te koppelen, was het de bedoeling de mogelijke onbetrouwbaarheden te compenseren.

Een andere mogelijke methode om de prestaties van de overheid te bepalen is het meten van de doorlooptijd. De doorlooptijd is de tijd die verstrijkt tussen het begin en het einde van een procedure. Krol en Passchier (1986) hebben de doorlooptijd van de wettelijke planprocedure van de Wet Ziekenhuisvoorzieningen bepaald aan de hand van de wettelijke termijnen. Deze hebben zij vergeleken met de werkelijk benodigde doorlooptijd van de planprocedure. Het verschil tussen formele en werkelijke tijd kan groot zijn. 
De Algemene Rekenkamer (1989-1990) heeft de doorlooptijd bepaald van de afgifte van bouwvergunningen door de staatssecretaris van Welzijn, Volksgezondheid en Cultuur aan gezondheidszorginstellingen. Ook hier werd de wettekst als bron gebruikt om de theoretische doorlooptijd te bepalen.

Baakman (1990) heeft de doorlooptijd geinventariseerd door het proces te reconstrueren van de manier waarop over de besluitvorming omtrent de nieuwbouw van een aantal ziekenhuizen in bepaalde regio's heeft plaatsgevonden. Baakman heeft briefwisselingen, notulen, notities, publicaties, onderzoeksrapporten en officiële stukken, zoals de Handelingen van de Tweede Kamer, de Staatscourant het Staatsblad, circulaires, nota's, verordeningen verslagen als bronnen gebruikt.

Uit het bovenstaande blijkt dat men voor het meten van de totale bestuurskosten van de gehele sector gebruik kan maken van secundaire gegevens. Het voordeel hiervan is dat men niet zelf gegevens hoeft te verzamelen, maar gebruik kan maken van materiaal dat al beschikbaar is. Dit kan onderzoekerstijd sparen. Een ander voordeel is dat men verschillende bronnen met elkaar kan vergelijken. Hierdoor kan men beoordelen of de resultaten overeenstemmen of van elkaar verschillen. Naar aanleiding hiervan kan men nagaan hoe de verschillen zijn te verklaren en men kan nagaan welk cijfer men het best kan hanteren. In deze verschillen schuilt echter een nadeel, namelijk dat de afstemming problemen kan opleveren: er kan sprake zijn van dubbeltelling of er kunnen andere kostenindelingen gebruikt zijn. Dit kan het geval zijn wanneer het materiaal met het oog op verschillende doeleinden is verzameld. Een ander nadeel is dat men afhankelijk is van het aanbod van cijfermateriaal. Wellicht zocht men eigenlijk andere gegevens, maar is men blij met enig aanbod überhaupt. Bovendien is een nadeel dat men wellicht niet precies weet wat wel en niet is meegerekend.

Uit het bovenstaande blijkt verder dat voor het meten van de bestuurskosten van een bepaalde overheidsmaatregel diverse gegevensverzamelingsmethoden mogelijk zijn. Men kan de onderzoekers laten registreren, men kan de betrokkenen zelf laten registreren, men kan de onderzoekers laten interviewen en de betrokkenen laten schatten of men kan uitgaan van de doorlooptijd.

Wanneer men onderzoekers de bestuurskosten laat registreren tijdens het beleidsproces, dienen zij gedurende het hele proces alle uitvoerenden te volgen. Zij moeten beschrijven en bijhouden wat iedereen doet en hoelang. Het voordeel van deze methode is dat de objectiviteit wordt bevorderd, aangezien de onderzoekers normaal gesproken geen belang hebben bij een bepaalde uitslag. Bovendien kan deze registratie steeds door dezelfde persoon of door een panel van personen gebeuren. Daardoor wordt in de hand gewerkt dat dit steeds op dezelfde manier plaatsvindt. Het nadeel van deze methode is dat er veel onderzoekstijd mee is gemoeid. Naast iedere uitvoerende dient immers in principe een onderzoeker te zitten. Verder kan alleen tijdens het verloop van het beleidsproces geregistreerd worden; registratie achteraf is niet mogelijk. Men moet zich dus beperken tot de actualiteit. Het verieden en de toekomst kunnen niet meegenomen worden. Dit brengt met zich mee dat de doorlooptijd van het onderzoek lang is, omdat beleidsprocessen ook vaak lang duren. Anders kunnen immers slechts een beperkt aantal gegevens verzameld worden. Verder moet men rekening houden met weerzin van de kant van degenen bij wie geregistreerd wordt en voelen de uitvoerenden zich bekeken, hetgeen het gedrag kan beïnloeden.

Een tweede mogelijke meetmethode van de bestuurskosten van een bepaalde maatregel is de betrokkenen zelf te laten registreren. Men kan uitvoerenden aan de hand van gestandaardiseerde formulieren en vragenlijsten zelf laten bijhouden wat 
zij precies doen en hoeveel tijd daarmee gemoeid is. Het voordeel van deze methode is dat het geen extra onderzoekerstijd kost. Terwill men werkt, houdt men zelf de registraties bij. Er hoeven geen aparte onderzoekers aangesteld te worden. Het nadeel is dat de schatting te hoog of te laag kan uitvallen door de betrokkenheid van degenen die registreren. Zij kunnen voordeel hebben of denken te hebben bij een bepaald meetresultaat. Onafhankelijke onderzoekers worden geacht objectiever te zijn. Bovendien is gebleken dat werknemers bijna altijd een grote aversie hebben tegen het kwantificeren van de hoeveelheid tijd die zij aan bepaalde activiteiten hebben besteed. Met name wanneer het werk betreft dat uit verschillende bezigheden bestaat. Ondanks deze beperkingen beschouwt Drenth (1989) de direct betrokkenen zelf als een betrouwbare bron, omdat alleen zijzelf weten hoelang zij ergens mee bezig zijn geweest.

Ten derde kan men de bestuurskosten bepalen door onderzoekers interviews te laten afnemen en daarbij de betrokkenen te laten schatten. Bij deze methode moeten de onderzoekers van tevoren zoveel mogelijk informatie verzamelen omtrent het beleidsproces. Aan de hand hiervan kunnen vragen worden opgesteld over activiteiten in het verleden en het heden. Het voordeel hiervan is dat het de objectiviteit bevordert door systematisch dezelfde, vantevoren vastgestelde, vragen te stellen. Een ander voordeel is dat de meting over het heden en het verleden kan gaan en niet beperkt is tot registratie van de actuele situatie. Een nadeel is dat meting van het verleden minder betrouwbaar is, bijvoorbeeld wanneer datgene wat gemeten wordt lang geleden is.

Ten vierde kan men de doorlooptijd van de uitvoering van een maatregel bepalen. Hiertoe kan men gebruik maken van de tijden die zijn voorgeschreven in wettelijke procedures. Deze termijnen kan men aanvullen met de werkelijke benodigdo doorlooptijd. Deze laatste kan men achterhalen aan de hand van schrittelijke bronnen, zoals briefwisselingen, notulen, officiële stukken. Ook de direct betrokken uitvoerende kunnen hiertoe worden geraadpleegd. Een voordeel is dat men meestal veel gegevens kan destilleren uit schriftelijke bronnen, die als betrouwbaar gelden. Een ander voordeel is dat de gegevensverzameling relatief snel kan gebreuren. Een nadeel is het feit dat de gegevens die men verkrijgt globaal. Directe meting van de bestede tijd biedt specifiekere gegevens.

Samengevat zijn de mogelijke dataverzamelingsmethoden om de bestuurskosten te meten, weergegeven in schema 4.3 . 
Schema 4.3 Mogelijke dataverzamelingsmethoden en de voor- en nadelen

\begin{tabular}{|c|c|c|}
\hline Methode: & Voordelen: & Nadelen: \\
\hline $\begin{array}{l}\text { verzameling secundaire } \\
\text { gegevens }\end{array}$ & $\begin{array}{l}\text { weinig onderzoekstijd } \\
\text { verschillende bronnen ver- } \\
\text { gelijken }\end{array}$ & $\begin{array}{l}\text { afstemmingsproblemen } \\
\text { herkomst onbekend } \\
\text { afhankelijk van aanbod }\end{array}$ \\
\hline onderzoeker registreent & $\begin{array}{l}\text { objectief } \\
\text { door een of meer dezelfde } \\
\text { personen } \\
\text { betrouwbaar }\end{array}$ & $\begin{array}{l}\text { veel onderzoekstijd } \\
\text { alleen heden te meten } \\
\text { weerzin bij geregistreer- } \\
\text { den } \\
\text { risico van extra hoge } \\
\text { produktie }\end{array}$ \\
\hline betrokkenen registreren & $\begin{array}{l}\text { geen extra onderzoekers- } \\
\text { tijd } \\
\text { betrouwbaar door directe } \\
\text { bron }\end{array}$ & $\begin{array}{l}\text { te hoge of te lage regis- } \\
\text { tratie } \\
\text { subjectief } \\
\text { aversie tegen registratie }\end{array}$ \\
\hline $\begin{array}{l}\text { onderzoeker interviewt / } \\
\text { betrokkene schat }\end{array}$ & $\begin{array}{l}\text { objectief } \\
\text { meting van heden en verle- } \\
\text { den }\end{array}$ & $\begin{array}{l}\text { minder betrouwbaar } \\
\text { naarmate langer gele- } \\
\text { den }\end{array}$ \\
\hline doorlooptijd & $\begin{array}{l}\text { objectief door schriftelijke } \\
\text { bronnen } \\
\text { relatief weinig onderzoe- } \\
\text { kerstijd }\end{array}$ & globaal \\
\hline
\end{tabular}

\section{§4.5 De meting van de bestuurskosten in de gezondheidszorg}

De bestuurskosten zullen worden geïnventariseerd aan de hand van de volgende cases: het Financieel Overzicht, het aanvragen van vergunningen op grond van artikel 18 van de Wet Ziekenhuisvoorzieningen en de totstandkoming van een provinciaal plan krachtens artikel 4 van de Wet Ziekenhuisvoorzieningen.

\section{Het Financieel Overzicht}

Het Financieel Overzicht is een van de weinige Nederlandse overheidsdocumenten waarin bestuurskosten worden gekwantificeerd. De staatssecretaris brengt ieder jaar als bijlage bij de begroting van volksgezondheid het Financieel Overzicht uit. Dit overzicht bevat beleidsvoornemens, produktiegegevens en kostenoverzichten. Het overzicht is per zorgsector onderverdeeld. Eén hoofdstuk betreft de bestuurskosten, die worden gepresenteerd onder de noemer van de kosten van beleid, administratie en beheer. Uitgaande van de hiervoor geformuleerde definitie, geven de kosten van beleid, administratie en beheer geen compleet beeld van de werkelijke hoogte van de bestuurskosten. De bestuurskosten van instellingen die overheidsbeleid uitvoeren, ontbreken bijvoorbeeld. Bij het hoofdstuk "kosten van beleid, administratie en beheer" zullen aanvullingen worden gezocht.

De dataverzamelingsmethode die hierbij zal worden gehanteerd is gebruikmaking van secundaire gegevens. Het gebied waarop het Financieel Overzicht betrekking heeft, is dermate breed dat het uitvoeren van inventarisaties ondoenlijk is. Bovendien is veel materiaal voor handen, alleen moet het vaak nog op de juiste manier bij elkaar worden gezet. 
De bepaling van de bestuurskosten aan de hand van het Financieel Overzicht vindt plaats op het hoogste aggregatieniveau. Gekeken wordt naar de bestuurskosten van de gehele sector. Er wordt geen onderscheid gemaakt naar individuele instellingen of instanties.

\section{Artikel 18 van de Wet Ziekenhuisvoorzieningen}

Op grond van artikel 18 zijn instellingen momenteel verplicht voor een negental kostbare voorzieningen een vergunning aan te vragen alvorens zij tot aanschaf mogen over gaan. Voorbeelden van dergelijke voorzieningen zijn niertransplantaties, hartchirurgie, in vitro fertilisatie. De afbakening van de maatregel is duidelijk. De procedure om voor een vergunning ex artikel 18 in aanmerking te komen is, hoewel gerelateerd aan andere regelingen, een duidelijk af te bakenen geheel. Ook de output levert geen problemen op: een instelling ontvangt een goedkeurende of een afwijzende reactie op een vergunningaanvraag. De maatregel zelf is formeel nog niet zo lang in werking en in de praktijk nog minder lang.

De dataverzamelingsmethode die is toegepast, is de bepaling van de doorlooptijd. De doorlooptijd is de tijd die verloopt tussen het begin en het einde van een procedure. Deze kan worden vastgesteld aan de hand van de formeel in de wettekst vastgelegde procedure en door het raadplegen van archiefstukken.

De bepaling van de bestuurskosten op grond van de doorlooptijd vindt plaats op een hoog aggregatieniveau. Uitgangspunt is weliswaar de uitvoering van een maatregel, maar de tijd die de afzonderlijke actoren aan de uitvoering hebben besteed, blijt buiten beschouwing. Gekeken wordt immers naar de totale doorlooptijd van de totstandkoming van de planningsbesluiten enerzijds en naar de totale doorlooptijd van de behandeling van de vergunningaanvragen anderzijds.

Artikel 4 van de Wet Ziekenhuisvoorzieningen;

Artikel 4 regelt de planning van ziekenhuisvoorzieningen. ledere regio diende op het moment van meting te beschikken over een plan voor elke categorie van voorzieningen. Zulke categorieën zijn bijvoorbeeld ziekenhuizen of verpleeghuizen. De afbakening levert ook hier geen problemen op. De planningsprocedure is wat dat betreft eenduidig. De output is het afgeleverde plan. Het recente tijdstip vormt in zoverre een probleem dat nog slechts enkele planprocedures geheel zijn afgerond.

De dataverzamelingsmethode is het inventariseren van de hoeveelheid tijd die alle direct betrokkenen hebben besteed aan de uitvoering. Hoewel aan deze meetmethode de nodige haken en ogen kleven, is het de meest directe manier om de bestuurskosten te meten.

De bepaling van de bestuurskosten die het gevolg zijn van de uitvoering van een maatregel vindt plaats op het allerlaagste niveau waar de maatregel wordt toegepast en wordt uitgesplitst naar de uitvoerende personen die de bestuurskosten direct maken.

Samengevat levert dit het onderstaande meetmodel op (zie schema 4.4). 
Schema 4.4 Meetmodel van de meting van de bestuurskosten in de gezondheidszorg

\begin{tabular}{|c|c|c|c|}
\hline Case: & $\begin{array}{l}\text { Aggregatieni- } \\
\text { veau: }\end{array}$ & Meeteenheid: & $\begin{array}{l}\text { Dataverzamelingsme- } \\
\text { thode: }\end{array}$ \\
\hline $\begin{array}{l}\text { Financieel Over- } \\
\text { zicht }\end{array}$ & $\begin{array}{l}\text { gehele sector } \\
\text { algemeen }\end{array}$ & $\begin{array}{l}\text { geld } \\
\text { formatieplaat- } \\
\text { sen }\end{array}$ & secundaire gegevens \\
\hline artikel 18 WZV & $\begin{array}{l}\text { een maatregel } \\
\text { algemeen }\end{array}$ & $\begin{array}{l}\text { verstreken tijd } \\
\text { aantal actoren }\end{array}$ & $\begin{array}{l}\text { doorlooptijd } \\
\text { inventarisatie proce- } \\
\text { dure }\end{array}$ \\
\hline artikel 4 WZV & $\begin{array}{l}\text { een maatregel } \\
\text { specifiek }\end{array}$ & $\begin{array}{l}\text { geïnvesteerde } \\
\text { tijd } \\
\text { aantal actoren }\end{array}$ & $\begin{array}{l}\text { bestede tijd } \\
\text { inventarisatie proce- } \\
\text { dure }\end{array}$ \\
\hline
\end{tabular}

\section{\$4.6 Samenvatting en conclusies}

Bij de meting zijn een aantal methodologische criteria van belang. Dit zijn de validiteit, betrouwbaarheid en generaliseerbaarheid.

Als aggregatieniveau komt voor de totale bestuurskosten de gehele sector in aanmerking. De bestuurskosten die het gevolg zijn van de uitvoering van een bepaalde maatregel registreert men op een lager niveau, al dan niet toegespitst op afzonderlijke actoren.

Als meeteenheid van bestuurskosten kan men geld, formatieplaatsen, het aantal produkten per tijdseenheid, de bestede tijd, verrichte activiteiten, de doorlooptijd of het aantal betrokken actoren hanteren.

Voor de meting van bestuurskosten zijn diverse dataverzamelingsmethoden denkbaar. Bestuurskosten kan men meten door deze af te leiden van secundaire gegevens, door onderzoekers te laten registreren, men kan betrokkenen zelf laten registreren, men kan de onderzoekers laten interviewen en de betrokkenen laten schatten of men kan de doorlooptijd inventariseren.

Het hoofdstuk "kosten van beleid, administratie en beheer" van het Financieel Overzicht zal aangevuld worden met ander secundair materiaal. Van het aanvragen van vergunningen voor kostbare artikel 18-voorzieningen door ziekenhuizen zal de doorlooptijd worden bepaald. Van de totstandkoming van een provinciaal plan ex artikel 4 van de Wet Ziekenhuisvoorzieningen zal de direct bestede tijd worden geïnentariseerd. 


\section{Hoofdstuk 5}

\section{BESTUURSKOSTEN IN HET FINANCIEEL OVERZICHT}

\section{$\S 5.1$ Inleiding}

In het vorige hoofdstuk is aangegeven hoe de bestuurskosten kunnen worden gemeten. Hierbij zijn de drie benaderingswijzen die worden gevolgd, uiteengezet. Het betreft de berekening van de bestuurskosten in de gezondheidszorg als aanvulling op het Financieel Overzicht, de bepaling van de bestuurskosten aan de hand van de doorlooptijd van een procedure en de meting van de bestuurskosten op grond van de tijd besteed aan de uitvoering van een maatregel.

In dit hoofdstuk wordt aandacht besteed aan het Financieel Overzicht. In het hoofdstuk "kosten van beleid, administratie en beheer" van het Financieel Overzicht wordt ingegaan op de bestuurskosten. Dit zijn de kosten van de bestuurlijke infrastructuur bij overheden en particulieren die het gevolg zijn van overheidsbesturing in de gezondheidszorg. In deze studie zal worden getracht de kosten van beleid, administratie en beheer uit het Financieel Overzicht aan te vullen tot bestuurskosten. Dit zal gebeuren door de zogeheten verborgen beleidskosten die zich bij instellingen voordoen, te inventariseren. De aanvulling van de kosten van beleid, administratie en beheer met de verborgen beleidskosten levert een beeld op van de bestuurskosten.

Het hoofdstuk "kosten van beleid, administratie en beheer" staat pas sinds kort in de belangstelling. Voorheen was het eerder een restpost van het Financieel Overzicht. Sinds de kosten van beleid, administratie en beheer echter na de kosten van geneesmiddelen de snelst groeiende kostenpost blijken te zijn, is de belangstelling toegenomen. De aandacht is nog vergroot door de verwachting dat de voorgenomen stelselwijziging de zogenoemde beheerskosten bij verzekeraars en bij instellingen zal doen toenemen. 
De opbouw van dit hoofdstuk is als volgt. Paragraaf 5.2 gaat in op het Financieel Overzicht. Hierin komen het karakter, de status, de totstandkoming en de structuur van het Financieel Overzicht aan de orde. Paragraaf 5.3 handelt over het hoofdstuk "kosten van beleid, administratie en beheer". Dit beschrijft de opbouw en de totstandkoming van het hoofdstuk en de verdeling en de hoogte van de kosten van beleid, administratie en beheer. Vervolgens wordt aangegeven wat ontbreekt in dit hoofdstuk en worden aanvullingen gegeven. Hierna wordt in paragraaf $5.4 \mathrm{de}$ meting geëvalueerd. Paragraaf 5.5 tenslotte bevat een samenvatting en de conclusies.

\section{§.2 De voorlopers van het Financieel Overzicht}

De eerste tekenen van hetgeen later een Financieel Overzicht zal gaan heten, dateren van het einde van de jaren zestig. Vanaf 1968 verschijnen namelijk op verzoek van het Directoraat-Generaal voor de Volksgezondheid de eerste overzichten van het Centraal Bureau voor de Statistiek onder de titel "Kosten en financiering van de gezondheidszorg in Nederland". Deze overzichten geven echter slechts een beeld van de kosten die in het verleden zijn gemaakt. Een raming voor de toekomst ontbreekt. Bestuurlijke informatie kan er dan ook nauwelijks uit geput worden.

Vanaf 1970 brengt de Ziekenfondsraad echter wel iets dergelijks, zij het alleen voor de eigen sector. Het zijn de jaarlijks uitgebrachte adviezen over de premiehoogte voor de Ziekenfondswet en de Algemene Wet Bijzondere Ziektekosten. Deze worden aangevuld met ramingen voor de middellange termijn. Zij hebben betrekking op de ontwikkeling van de kosten van verstrekkingen, de premie-opbrengsten en het benodigde premiepercentage.

Vlak daarvoor onderneemt het ministerie van Volksgezondheid en Milieuhygiëne in de Volksgezondheidsnota (1965-1966) een poging om voor een aantal sectoren van de gezondheidszorg de ontwikkelingen en het beleid voor de toekomst te kwantificeren. Vervolgens geeft de Structuurnota Gezondheidszorg (1973-1974) een aanzet tot enerzijds een raming van de te verwachten kosten en anderzijds een aanduiding van de gewenste beperking van de kosten.

In de periode 1974 tot 1976 verschijnt onder eindverantwoordelijkheid van de Centrale Raad voor de Volksgezondheid in samenwerking met het Centraal Bureau voor de Statistiek (dat de gegevens ter beschikking stelt) en het Centraal Plan Bureau (dat de gegevens analyseert, prognose-modellen ontwerpt en de computerberekeningen uitvoert) het rapport "Benadering van de ontwikkeling van de kosten van de Nederlandse Gezondheidszorg" (Centrale Raad voor de Volksgezondheid, 1974, 1975, 1976). Hierin schetst de Centrale Raad globaal de ontwikkeling van de kosten van de voorafgaande jaren en geeft een prognose voor de ontwikkeling in de nabije toekomst. Er wordt nog geen rekening gehouden met veranderingen als gevolg van beleidsvoornemens.

Onder meer naar aanleiding van het verschijnen van bovengenoemde rapporten, maar ook omdat blijkt dat de kosten van de gezondheidszorg blijven toenemen, signaleert de toenmalige staatssecretaris Hendriks in de nota "Beleidsvoornemens betreffende de kostenbeheersing in de gezondheidszorg" (1975-1976) dat er behoefte is aan kwantificering van de financiële gevolgen van de beleidsvoornemens. Ook ontbreekt het volgens de staatssecretaris aan eenduidige kosten- en 
financieringscijfers met betrekking tot de gezondheidszorg. Hij constateert dat een groot aantal instanties, zoals het Centraal Plan Bureau, het Centraal Bureau voor de Statistiek, de Centrale Raad voor de Volksgezondheid, de Ziekenfondsraad, het ministerie van Volksgezondheid en Milieuhygiëne, het Nationaal ZiekenhuisInstituut, reeds cijfermatige opstellingen van kostenontwikkelingen produceert, maar dat de uitkomsten hiervan nogal uiteenlopen. De oorzaak hiervan is gelegen in het feit dat deze instanties verschillende uitgangspunten hanteren betreffende:

- het effect van voorgenomen maatregelen;

- de loon- en prijsontwikkeling;

- de gehanteerde ramingsmethoden;

- de gehanteerde definities.

Daarnaast is men veelal niet bekend met de voorgenomen beleidsmaatregelen, hetgeen ook weer verschillende uitkomsten oplevert.

Teneinde een zekere harmonisatie en coördinatie tussen de diverse financiële publicaties te bewerkstelligen en de financiële gevolgen van beleidsvoornemens te kunnen aangeven in aanvulling op de Memorie van Toelichting bij de rijksbegroting en om een afweging te kunnen maken omtrent werkgelegenheids- en arbeidsvoorwaardenvraagstukken, kondigt de staatssecretaris het volgende besluit aan: het departement zal periodiek een overzicht opstellen "van de kosten van de gehele gezondheidszorgsector waarin ook een kwantificering is opgenomen van de effecten van het gerealiseerde beleid en van voorgenomen beleidswijzigingen" (Beleidsvoornemens betreffende de kostenbeheersing in de gezondheidszorg, 1975-1976, p.15).

Daarmee zal een integraal inzicht worden geboden in de ontwikkeling van de personeelsvoorziening, de beddencapaciteit, de honoraria, lonen en salarissen, de groei van het aantal vrije beroepsbeoefenaren, het gebruik van het aantal vrije beroepsbeoefenaren, het gebruik van de medische diensten en de uit deze ontwikkeling voortvloeiende kosten en financiering. Dit is noodzakelijk aangezien de rijksbegroting alleen dit beeld niet kan geven. Slechts een gering percentage van de zorgsector, gemiddeld ongeveer tien procent, wordt immers uit rijkssubsidies gefinancierd (zie hierover verder paragraaf 5.2.2). Beschouwt men uitsluitend de gezondheidszorgsector dan wordt de overheidsbijdrage in de financiering nog minder, namelijk vijf procent. Ook naar internationale maatstaven is dit weinig.

In september 1977 verschijnt het eerste "Financieel Overzicht Gezondheidszorg". Het is echter nooit als formeel stuk aan het parlement aangeboden, omdat het door de korte voorbereidingstijd nog te onvolledig werd geacht (Het beleid ter zake van de gezondheidszorg met het oog op de kostenontwikkeling, 1978-1979).

\section{§ 5.2.1 De doeleinden van het Financieel Overzicht}

De doeleinden van het Financieel Overzicht zijn in de loop der jaren aanzienlijk veranderd. Het eerste Financieel Overzicht (1977-1978) beoogde slechts het kwantitatief in beeld brengen van de kosten van de gehele gezondheidszorg door middel van het doorberekenen van autonome en trendmatige ontwikkelingen. Daarnaast werd een aantal beleidsalternatieven doorberekend zonder dat expliciete keuzes werden gemaakt. Het eerste Financieel Overzicht heeft dan ook een "verkennend" karakter (Nationale Raad voor de Volksgezondheid, 1984, p.10). Er is weinig verschil met de eerdere kostenrapporten van de Centrale Raad voor de Volksgezondheid, het Centraal Bureau voor de Statistiek en het Centraal PlanBu- 
reau. De kwalificatie "Statistisch Zakboek" van Van Montfort (1990) is hier dan ook op zijn plaats.

Met het verschijnen van het tweede Financieel Overzicht (1978-1979) komt in de doeleinden reeds enige verandering. Dit Financieel Overzicht mikt op een meer beleidsmatige benadering, zoals blijkt uit de volgende passage: "de vermelde prognose van de totale kosten in de gezondheidszorg dient niet alleen te worden beschouwd als een projectie van de financiële gevolgen van een aantal historische, ten dele autonome ontwikkelingen en bewuste beleidsvoering, maar ook als een aanduiding van de begrenzing van de financiële mogelijkheden, waarbinnen de ontwikkelingen zich in de komende jaren zullen voltrekken" (p.4). In Bestek '81 (1977-1978), waarin het regeringsbeleid van het kabinet Van Agt I wordt uiteengezet, komt dit tot uitdrukking. Bovendien biedt het tweede Financieel Overzicht ook inzicht in de wijze van financiering van de gezondheidszorg.

Kennelijk acht de Tweede Kamer de toezegging in het Financieel Overzicht nog te vrijblijvend. Dit kan tenminste worden afgeleid uit het feit dat tijdens de behandeling van het wetsontwerp Tarieven Gezondheidszorg de kamerleden Lansink en De Korte een motie (1979-1980) indienen om het Financieel Overzicht om te vormen tot een "meerjarenraming met een taakstellend macro-budgettair karakter". Het is de bedoeling dat voor een aantal jaren maximum-bedragen worden vastgesteld, die de financiële kaders aangeven waarbinnen de ontwikkelingen in de gezondheidszorg zich dienen te voltrekken. Zowel de toenmalige Centrale Raad voor de Volksgezondheid als de Ziekenfondsraad adviseren positief over dit voorstel.

in de "Nota inzake het Financieel Overzicht van de gezondheidszorg" (1980-1981) neemt staatssecretaris Veder-Smit enigszins afstand van deze aanbevelingen. Zij ziet de meerjarenraming vooral als een verkenning van te verwachten toekomstige ontwikkelingen. Hierdoor wordt het voor besluitvormers mogelijk zich bij hun beslissingen rekenschap te geven van de financiële gevolgen van deze beslissingen en van alternatieve beslissingen. De meerjarenramingen kunnen in een vroeg stadium ongewenste ontwikkelingen signaleren. Het beleid kan daardoor tijdig worden bijgestuurd. De staatssecretaris geeft dan ook de voorkeur aan de kwalificatie "leidend" voor het karakter van het Financieel Overzicht. Dit blijt van toepassing van 1980 tot omstreeks 1983

Vanaf het verschijnen van het zesde Financieel Overzicht (1983-1984) krijgt het Financieel Overzicht een normatief karakter. Het wordt expliciet "taakstellend" (p.3) genoemd. Dit houdt in dat "de Regering de grenzen aangeeft van de voor de gezondheidszorg beschikbare middelen. Dit betekent dat overschrijdingen in beginsel dienen te worden gecompenseerd" (p.3). Het taakstellende deel geldt alleen voor het eerstvolgende jaar. De meerjarenraming, die een indicatief karakter blijft behouden, geldt voor vier jaren.

Het begrip "taakstellend" zou naar de mening van de Nationale Raad (1984) zelfs nog kunnen worden aangescherpt tot een ontwikkeling en uitbreiding van de toetsingsfunctie van het Financieel Overzicht. De Nationale Raad is er voorstander van dat in het Financieel Overzicht tevens wordt nagegaan of en in hoeverre in het verleden gestelde beleidsprioriteiten zijn verwezenlijkt. De Raad acht het niet voldoende wanneer alleen een vergelijking wordt gemaakt tussen de beoogde en gerealiseerde kostenontwikkelingen. Er dienen ook consequenties aan te worden verbonden.

De Ziekenfondsraad (1984) is aanvankelijk niet zo gecharmeerd van dit voorstel van de Nationale Raad. De Ziekenfondsraad voert aan dat de uitgaven in de gezondheidszorg door de overheid niet bindend kunnen worden voorschreven. In de eerste plaats laten de wettelijke aanspraken van de verzekerden, op basis van 
de in de sociale verzekeringen vastgelegde rechten, een dergelijke stringente macro-budgettering niet toe. In de tweede plaats maakt de financieringsstructuur een zodanig bindende taakstelling niet uitvoerbaar. De budgettering wordt immers nog maar beperkt toegepast (wel de ziekenhuizen, niet de specialisten). Daar komt bij dat de overheid niet over het wettelijke instrumentarium beschikt om ten aanzien van alle factoren die de kosten van de gezondheidszorg beinvloeden, regelend op te treden. Vandaar dat de Ziekenfondsraad van mening is dat het Financieel Overzicht niet zo zeer een bindend als wel een leidend budget zou moeten blijven.

In 1985 kwalificeert de Ziekenfondsraad het destijds verschenen Financieel Overzicht als richtinggevend, vanwege de "aanzienlijke tussentijdse bijstellingen" die vanaf die tijd regelmatig plaatshebben, zoals de kortingen op de beheersbudgetten van de ziekenfondsen.

In zijn advies van 1987 neemt de Nationale Raad dit standpunt van de Ziekenfondsraad over. De Nationale Raad geeft aan dat de taakstelling in het Financieel Overzicht slechts een kabinetsafspraak betreft die alleen bindend is voor de overheid. Het veld is er niet aan gebonden. Desalniettemin heeft het veld zich er tot dan toe meestal wel aan geconfirmeerd. Deze consensus dreigt echter verloren te gaan door te omvangrijke bezuinigingen die steeds meer en vaker door de overheid aan de gezondheidszorg worden opgelegd (Nationale Raad voor de Volksgezondheid, 1987).

$\mathrm{Na}$ de taakstelling zou toetsing van de realisering en van de beleidsdoelstellingen de volgende logische stap zijn. Naar aanleiding van deze toetsing kan het beleid geheel of op onderdelen worden bijgesteld, dan wel worden aangescherpt. Doordat de (kosten)cijfers pas na twee jaar definitief zijn, is snelle evaluatie moeilijk. Op dit moment worden kosten uit een bepaald jaar dan ook in feite driemaal geëvalueerd:

1. Het (gecorrigeerde) taakstellende kader voor het jaar waarin het Financieel Overzicht verschijnt, wordt vergeleken met de (door het veld) verwachte feitelijke ontwikkeling van de kosten. Hier is dus sprake van een zeer globale toetsing.

2. In het volgende Financiële Overzicht wordt de wederom bijgestelde taakstelling vergeleken met de "voorlopig vastgestelde" getallen. De eerste evaluatie wordt dan dus bijgesteld.

3. Weer een jaar later worden de kosten, na een nieuwe correctie, definitief vastgesteld. Dan pas blijkt ook duidelijk de over- of onderschrijding van de feitelijke kosten ten opzichte van de oorspronkelijke en de bijgestelde taakstelling (Nationale Raad voor de Volksgezondheid, 1988).

Deze evaluatie betekent in de praktijk echter steeds bijstelling naar boven van tevoren gestelde grenzen. De Kam (1990) illustreert deze ontwikkeling aan de hand van het volgende voorbeeld. "Het blijkt dat de in 1983 door het eerste kabinetLubbers voor 1986 geformuleerde financiële ruimte uiteindelijk met negen procent is bijgesteld en overschreden. De voor 1990 voorziene uitkomsten liggen al weer vijf procent hoger dan in 1986 bij het aantreden van het tweede kabinet-Lubbers werd voorzien" (p.641). Men zou dan ook niet moeten spreken over taakstelling, maar eerder over signalering van overschrijding, waarna bijstelling automatisch volgt.

Daar komt nog bij dat de gepresenteerde cijfers van voorafgaande jaren veelvuldig worden gewijzigd (Meulmeester, 1986). Deze aanpassingen bestaan uit statistische correcties, externe factoren (verhuizingen), wijzingen in eerdere kaders, loon- en prijsbijstellingen. Op zich zou toetsing nog wel mogelijk zijn als duidelijk was waar correcties zijn uitgevoerd, hoe deze zijn bepaald en wat de consequenties hiervan zijn. Het Financieel Overzicht verschaft echter nauwelijks duidelijkheid over de 
Concluderend kan men stellen dat het doel van het Financieel Overzicht aanvankelijk slechts bestaat uit het getalsmatig weergeven van ontwikkelingen in de gezondheidszorg. Daarna worden de actuele ontwikkelingen uitgebreid met ramingen van toekomstige ontwikkelingen. Vervolgens veranderen de ramingen in taakstellend voorgeschreven maximale kosten.

\section{§.2.2 Het bereik van het Financieel Overzicht}

Het bereik van het Financieel Overzicht is in de loop der jaren steeds breder geworden. Aanvankelijk betreft het Financieel Overzicht uitsluitend de gezondheidszorg. De naamgeving is het Financieel Overzicht Gezondheidszorg.

Met ingang van 1984 is ook de welzijnssector in het Financieel Overzicht opgenomen. De naam wordt dan Financieel Overzicht Gezondheidszorg en Maatschappelijke Dienstveriening, daarna Financieel Overzicht Gezondheidszorg en Maatschappelijk Welzijn genoemd. Overwegingen om dit te doen waren de volgende:

- een samenhangend beleid tot stand te brengen voor de volksgezondheid en de maatschappelijke dienstverlening:

- de vorming van het ministerie van Welzijn, Volksgezondheid en Cultuur;

- de Wet Gezondheidszorg en Maatschappelijke Dienstverlening zou het wettelijke fundament voor het Financieel Overzicht gaan bieden. Het Financieel Overzicht zou als financieel referentiekader gaan dienen bij het opstellen van Regionale Financiële Overzichten. Op basis hiervan zouden zogenoemde Marginale Financiële Kaders worden geformuleerd. Doordat beide genoemde wetsvoorstellen echter weer zijn ingetrokken zijn de regionale kaders ook nooit ontwikkeld. Hierop vooruitlopend is echter wel alvast de maatschappelijke dienstverlening in het Financieel Overzicht geintegreerd.

(Financieel Overzicht Gezondheidszorg en Maatschappelijke Dienstverlening 1985, 1984-1985).

Het maatschappelijk welzijn-deel van het Financieel Overzicht en Maatschappelijke Dienstverlening bevat de hoofdstukken betreffende voorzieningen voor bejaarden, gezinsverzorging, voorzieningen voor jeugd- en drughulpverlening, algemeen maatschappelijke dienstverlening en voorzieningen voor gehandicapten.

Met name de Nationale Raad heeft ervoor gepleit (onder andere Nationale Raad voor de Volksgezondheid, 1983) bij de hoofdstukindeling van het Financieel Overzicht uit te gaan van de verschillende voorzieningencategorieën, ook wel zorgsectoren genoemd. Door deze zorgsectoren als geheel te presenteren worden bijvoorbeeld de voorzieningen van de geestelijke gezondheidszorg niet langer over twee hoofdstukken (intramuraal en extramuraal) en twee delen (gezondheidszorg en welzijn) verspreid zijn, maar in eén hoofdstuk bij elkaar gebracht. Een nadeel is wel dat bijvoorbeeld de Psychiatrische Afdelingen van Algemene Ziekenhuizen in deze nieuwe situatie toch nog onderdeel uitmaken van het hoofdstuk ziekenhuizen, terwijl sprake is van een voorziening voor geestelijke gezondheidszorg.

Met ingang van het in 1988 verschenen Financieel Overzicht, het Financieel Overzicht Zorg, wordt de suggestie van de Nationale Raad overgenomen. Bovendien zijn de gezondheidszorg- en het maatschappelijk welzijn-delen geintegreerd, waardoor de sector als geheel is uitgebreid. Dit heeft nadelige gevolgen voor de vergelijkbaarheid van het cijfermateriaal door de jaren heen. Verder neemt het 
aandeel van de overheidsfinanciering toe. De gezinsverzorging, het maatschappelijk werk, de verslaafdenzorg en de bejaardenoorden worden immers voor een groot deel met belastingmiddelen gefinancierd. De verdeling van de financiering geeft echter een vertekend beeld, doordat per saldo de overheidsuitgaven niet stijgen. De zorgsector is alleen uitgebreid.

Het nieuwe Financieel Overzicht weerspiegelt tevens de nieuwe organisatiestructuur van het ministerie van Welzijn, Volksgezondheid en Cultuur.

Het bereik van het Financieel Overzicht is dus is de loop der jaren aanzienlijk uitgebreid. Het Financieel Overzicht betreft niet langer uitsluitend de gezondheidszorg, maar behelst tevens de gehele welzijnssector.

\section{$\S$ 5.2.3 De staatsrechtelijke status van het Financieel Overzicht}

De staatsrechtelijke status van het Financieel Overzicht is van meet aan onduidelijk geweest. De kamerleden Lansink en De Korte hebben zelfs een motie (1979-1980) ingediend om aan staatssecretaris Veder-Smit hierover duidelijkheid te vragen. De achterliggende bedoeling was te pleiten voor een wettelijke status van het Financieel Overzicht. In 1980 heeft de staatssecretaris aan de toenmalige Centrale Raad voor de Volksgezondheid verzocht te adviseren over de status en de positie van het Financieel Overzicht. De Centrale Raad heeft dit verzoek ingewilligd en aan dit onderwerp een advies gewijd (Centrale Raad voor de Volksgezondheid, 1980). De Ziekenfondsraad is in diverse adviezen (onder andere in 1982 en 1983) hierop ingegaan. De Vaste Commissie voor de Volksgezondheid heeft er eveneens over gediscussieerd (1980-1981).

Op grond van al deze adviezen stelde de staatssecretaris in 1981 de "Nota inzake het Financieel Overzicht van de Gezondheidszorg" (1980-1981) op. Hierin zegde zij toe in te zullen gaan op de status-kwestie. In deze nota erkent de staatssecretaris dat het Financieel Overzicht formeel niet meer is dan een beleidsnota die, aanvankelijk als bijlage maar tegenwoordig als zelfstandig document, wordt toegevoegd aan de rijksbegroting van Volksgezondheid. Het Financieel Overzicht geeft inzicht in de financiële gevolgen van de in de Memorie van Toelichting op de rijksbegroting uiteengezette beleidsvoornemens.

In tegenstelling tot de rijksbegroting heeft het Financieel Overzicht geen wettelijke status. Het Financieel Overzicht kan ook moeilijk een wet worden die iets afdwingt. Immers, de financiering in de gezondheidszorg vormt een eigen systeem, dat in hoge mate berust op de rechten van verzekerden en dat verankerd is in het sociale zekerheidsstelsel. De mate waarin die rechten worden gebruikt, onttrekt zich grotendeels aan beinvloeding door de overheid.

Het Financieel Overzicht heeft echter wel degelijk een zekere staatsrechtelijke status, zoals iedere andere beleidsnota die de voornemens van de regering bevat. Het parlement kan hierover bijvoorbeeld zijn oordeel geven en via een motie wijzigingsvoorstellen indienen. Daar staat evenwel tegenover dat het parlement het Financieel Overzicht niet amenderen (Leenen en Roscam Abbing. 1986). Staatssecretaris Veder-Smit heeft echter tijdens het overleg van de Vaste Commissie voor Volksgezondheid inzake het Financieel Overzicht (1980-1981) toegezegd dat wijzigingsvoorstellen van het parlement over het Financieel Overzicht door de regering zoveel mogelijk zullen worden verwerkt, mits de regering de wijzigingen aanvaardt. Het Financieel Overzicht bestaat echter voor een deel uit prognoses die zich nu eenmaal naar hun aard niet lenen voor wijziging. 
Toch wordt het Financieel Overzicht alom beschouwd als een belangrijk document voor het bepalen en beoordelen van de financiële ontwikkelingen in de gezondheidszorg. Het probleem is evenwel dat wanneer het parlement de Rijksbegroting goedkeurt, dit formeel niet geldt voor het Financieel Overzicht aangezien dit een bijlage is. De praktijk is echter dat de regering het Financieel Overzicht materieel behandelt alsof het de Rijksbegroting betreft.

Hier komt nog bij dat de overheid strikt genomen geen zeggenschap heeft over de financiële middelen in de gezondheidszorgsector. Het betreft hier immers nauwelijks begrotingsgelden, maar hoofdzakelijk verzekeringsgelden, waarop verzekerden aanspraak kunnen maken. Echter, de overheid stelt wel het inkomensafhankelijke deel van de premies voor de Ziekenfondswet en de Algemene Wet Bijzondere Ziektekosten vast, dus heeft als zodanig ook een zekere zeggenschap.

De verdeling van de financieringsgelden van de zorgsector is in de jaren tachtig als volgt: 60 tot 65 procent wordt gefinancierd krachtens de Ziekenfondswet en de Algemene Wet Bijzondere Ziektekosten, 25 tot 30 procent uit particuliere betalingen en ongeveer 10 procent middels overheidssubsidies.

In de jaren zeventig, toen echter werd uitgegaan van de gezondheidszorgsector en niet van de zorgsector, was de verhouding respectievelijk 70 procent, 25 procent en 5 procent. Dit houdt in dat de overheid momenteel over slechts 10 procent van de uitgaven voor gezondheidszorg directe zeggenschap heeft. Over de resterende 90 procent kan zij wel met kracht nastreven dat dit deel binnen de ramingen van het Financieel Overzicht blijft. Zij kan dit formeel echter niet afdwingen. Hier moet echter opgemerkt worden dat de verdeling tussen overheids- en particuliere gelden ook een kwestie van definitie is. Wanneer men uitgaat van het collectief gefinancierde deel, namelijk inclusief de gelden van de Ziekenfondswet en de Algemene Wet Bijzondere Ziektekosten, wordt het aandeel van de overheid ineens veel groter.

Daar staat tegenover dat de overheid op basis van de planningswetgeving en de budgettering wel de omvang van de capaciteit van bijvoorbeeld intramurale voorzieningen kan begrenzen. Het bindende element voor de gezondheidszorg ligt dan ook niet zozeer in het Financieel Overzicht, als wel in de hantering van het beleidsinstrumentarium van de overheid dat wel bij wet is vastgelegd. Hierbij valt te denken aan planning (Wet Ziekenhuis Voorzieningen), tarifiëring en budgettering (Wet Tarieven Gezondheidszorg) en financiering en premievaststelling (Ziekenfondswet en Algemene Wet Bijzondere Ziektekosten). Door het bezigen van deze instrumenten kan de overheid proberen te bereiken dat de kosten van de gezondheidszorg binnen de gestelde kaders blijven.

\section{§ 5.2.4 De totstandkoming van het Financieel Overzicht}

Bij de totstandkoming van het Financieel Overzicht is sprake van een vaste cyclus. Onmiddellijk nadat een Financieel Overzicht in september is gepubliceerd, starten de Nationale Raad en de Ziekenfondsraad hun activiteiten. Deze monden in het voorjaar van het volgende jaar uit in twee afzonderlijke adviezen omtrent het komende Financieel Overzicht.

De Nationale Raad houdt zich met name bezig met de algemene aspecten, de prioriteitenstellingen en de kostenontwikkeling (Visscher, 1988). De Raad baseert zijn advies enerzijds op het voorafgaande Financieel Overzicht en wat hierover tijdens de behandeling in het parlement naar voren is gebracht en anderzijds op de adviezen van de overkoepelende organisaties, zoals de Nationale Ziekenhuisraad 
(thans Zorgfederatie), de Nederlandse Vereniging voor Ambulante Geestelijke Gezondheidszorg, de Nationale Kruisvereniging (thans samen met de gezinsverzorging de Landelijke Vereniging voor Thuiszorg), de Koninklijke Nederlandse Maatschappij ter bevordering der Geneeskunst, het Interprovinciaal Overleg, de Vereniging van Nederlandse Gemeenten, de Vereniging van Nederlandse Ziekenfondsen (thans: Zorgverzekeraars), het Kontaktorgaan Landelijke Organisaties van Ziektekostenverzekeraars, patiëntenorganisaties. leder van deze organisaties wordt verzocht zijn wensen en prioriteiten te inventariseren, kenbaar te maken en te trachten de financiële consequenties ervan aan te geven. De afgelopen jaren zijn de adviezen van deze organisaties overigens vaak integraal als bijlage toegevoegd aan de adviezen van de Nationale Raad. Een speciale commissie, de Commissie Voorbereiding Advies Financieel Overzicht, stelt uiteindelijk het advies op.

De Ziekenfondsraad spitst zijn advies toe op de financiering van de gezondheidszorg, de Ziekenfondswet en de Algemene Wet Bijzondere Ziektekosten. Binnen de Ziekenfondsraad is een Commissie Financiële Zaken aktief die het advies voorbereidt, waarna de Raad het vaststelt.

Naast de vooral inhoudelijke adviezen van de Nationale Raad en de Ziekenfondsraad laat het Centraal Planbureau zijn licht schijnen over de financieel-technische aspecten op macro-niveau. Het Centraal Planbureau schetst de verwachte ontwikkelingen van de economie in de komende jaren.

Over de manier waarop het ministerie van Welzijn, Volksgezondheid en Cultuur het Financieel Overzicht opstelt is voor het eerst in het twaalfde Financieel Overzicht (1988-1989) inzicht geboden. Wanneer bovengenoemde adviezen in het voorjaar zijn afgerond, wordt het departement bijgestaan door vijf zogenaamde rekengroepen (en vijf sub-rekengroepen). Deze rekengroepen bestaan uit technische (van het Centraal Planbureau, het Centraal Bureau voor de Statistiek en de Nationale Raad voor de Volksgezondheid) en inhoudelijke (namens de betrokken instellingen of personen) deskundigen enerzijds en medewerkers van het ministerie van Welzijn, Volksgezondheid en Cultuur van ondersteunende afdelingen (Financieel Beleid Gezondheidszorg) en beleidsafdelingen (eerstelijn, intramuraal) anderzijds. De meeste leden van de rekengroepen hebben hun hoofdfunctie buiten het ministerie van Welzijn, Volksgezondheid en Cultuur. Het doel hiervan is een veelzijdige deskundigheid en de acceptatie te bevorderen en in brede kring inzicht te bieden in de gebruikte methodieken.

De rekengroepen nemen elk één sector van de gezondheidszorg, zoals de intramurale gezondheidszorg of de extramurale gezondheidszorg, voor hun rekening. Zij geven overigens slechts technische bijstand en dragen geen verantwoordelijkheid voor de uiteindelijke inhoud. Zij beoordelen de bovengenoemde adviezen van de koepelorganisaties, stemmen ze op elkaar af, bekijken het cijfermateriaal en bundelen dit. De meestvoorkomende problemen waarmee de rekengroepen te kampen hebben zijn: het bereiken van gelijkheid in de gehanteerde begrippen en definities, de keuze van de (beleidsmatig) meest relevante en haalbare indeling in (sub)sectoren, het voorkomen van lacunes en dubbeltellingen, het vergelijkbaar houden van de informatie over de jaren heen en de uitsplitsing van de kostenontwikkeling in de volume-ontwikkeling, de algemene prijsontwikkeling en de prijsontwikkeling die het gevolg van het gevoerde beleid ten aanzien van de zorgsector is geweest. Tenslotte blijt het een probleem om de kosten die op transactiebasis (daarbij wordt rekening gehouden met het verbruik en de waardevermindering ofwel afschrijving, $\mathrm{MH}$ ) worden weergegeven en de financiering die op kasbasis (de inkomsten en uitgaven worden opgevoerd in het jaar waarin 
betaling plaats vindt ofwel investeringen, $\mathrm{MH}$ ) plaatsheeft, op elkaar af te stemmen (Nationale Raad voor de Volksgezondheid, 1989).

Nadat de rekengroepen hun werk hebben voltooid, worden vervolgens de prognoses opgesteld door het beleid te vertalen in cijfers voor de toekomst. Dit geschiedt niet in de rekengroepen, maar op het departement. Bij het opstellen van de kostenraming werkt het Centraal Planbureau mee. De interdepartementale werkgroep Coördinatie Financiële Berichtgeving stemt tenslotte de diverse hoofdstukken af met andere ministeries, zoals Sociale Zaken en Economische Zaken. De werkgroep zorgt er tevens voor dat rekening wordt gehouden met andere financiele regeringsdocumenten, zoals de Miljoenennota en de Financiële Nota Sociale Zekerheid (Financieel Overzicht Zorg 1989, 1988-1989).

Uiteindelijk resulteert dit in een Financieel Overzicht, dat in september aan het parlement wordt aangeboden en daarna in oktober en november tijdens de behandeling van de begroting aan de orde komt. Hierna begint de cyclus weer opnieuw. Schematisch ziet de totstandkoming van het Financieel Overzicht er als weergegeven in schema 5.1.

\begin{tabular}{|c|c|}
\hline \multicolumn{2}{|c|}{ Schema 5.1 De totstandkoming van het Financieel Overzicht } \\
\hline $\begin{array}{l}\text { december } \\
\text { januari } \\
\text { februari } \\
\text { maart }\end{array}$ & $\begin{array}{l}\text { voorbereiding adviezen door Nationale Raad en overkoepelende } \\
\text { organisaties), Ziekenfondsraad en Centraal Planbureau }\end{array}$ \\
\hline april & $\begin{array}{l}\text { advies van Nationale Raad, Ziekenfondsraad, Centraal Plan- } \\
\text { bureau }\end{array}$ \\
\hline $\begin{array}{l}\text { mei } \\
\text { juni } \\
\text { juli } \\
\text { augustus }\end{array}$ & $\begin{array}{l}\text { voorbereiding Financieel Overzicht in rekengroepen van ministe- } \\
\text { rie en afronding door werkgroep Coördinatie Financiële Bericht- } \\
\text { geving }\end{array}$ \\
\hline september & aanbieden Financieel Overzicht aan Tweede Kamer \\
\hline $\begin{array}{l}\text { oktober } \\
\text { november }\end{array}$ & $\begin{array}{l}\text { behandeling Financieel Overzicht bij begroting van ministerie van } \\
\text { WVC }\end{array}$ \\
\hline \multicolumn{2}{|c|}{ Gebaseerd op: } \\
\hline
\end{tabular}

In de loop der jaren is dus een vaste systematiek ontstaan met betrekking tot de totstandkoming van het Financieel Overzicht. Er is sprake van een cyclus die ieder jaar opnieuw wordt doorlopen.

\section{§ 5.2.5 De opbouw van het Financieel Overzicht}

De structuur van het Financieel Overzicht is van 1977 tot 1989 niet of nauwelijks gewijzigd. Het Financieel Overzicht Gezondheidszorg bestond aanvankelijk uit een inleidend algemeen hoofdstuk, dat gewijd was aan de gehele sector van de gezondheidszorg en zes hoofdstukken die ieder één sector behelsden. 
Het inleidende hoofdstuk van de Financiële Overzichten bevatten veelal de volgende onderdelen. Allereerst worden de beleidsvoornemens uiteengezet en een prioriteitenstelling gepresenteerd, al dan niet op grond van eerder gepubliceerde nota's, regeerakkoorden of andere afspraken. Genoemd worden in de loop van de twaalf jaren Financiële Overzichten onder andere de Structuurnota (1974), de nota "Het beleid terzake van de gezondheidszorg met het oog op de kostenontwikkeling", de nota "Volksgezondheid bij beperkte middelen" (1984). Bestek '81, de zogenaamde "package deal" gesloten tussen de staatssecretaris enerzijds en de Nationale Ziekenhuisraad, de Vereniging van Nederlandse Ziekenfondsen en het Kontaktorgaan Landelijke Organisaties van Ziektekostenverzekeraars anderzijds (over het overhevelen van $f 5$ miljoen van de intramurale naar de collectief-preventieve sector, nieuwe richtlijnen voor de aanschaf van medische apparatuur, beddenreductie). Uit deze nota's en andere documenten zijn onder meer de volgende prioriteitenstellingen te destilleren: versterking van de eerstelijn ten koste van de tweedelijn, beddenreductie, beperking van personeel (bijvoorbeeld fysiotherapeuten), verlaging van het bouwplafond, salarismatiging. Deze beleidsvoornemens worden in de inleiding van een Financieel Overzicht naar voren gebracht.

Dan volgt een algemene indruk van hetgeen het voorafgaande jaar is bereikt door de resultaten af te zetten tegen de beleidsvoornemens van het jaar ervoor. Hierbij wordt bijvoorbeeld nagegaan of de intramurale sector inderdaad middelen heeft ingeleverd ten gunste van de extramurale sector.

Tenslotte worden de algemene ontwikkelingen in de gezondheidszorg weergegeven. Daarbij wordt bijvoorbeeld geconstateerd dat het aantal beroepsbeoefenaren in de loop van bepaalde jaren is toegenomen.

De hoofdstukindeling die hierna volgt is overgenomen van de systematiek die het Centraal Bureau voor de Statistiek hanteert voor de statistiek "Kosten en financiering van de gezondheidszorg in Nederland". Op enkele marginale aanpassingen na heeft de hoofdstukindeling van de zorgsector tot 1989 als volgt uitgezien.

\section{De gehele gezondheidszorg;}

De totale kosten en de financiering van de gehele gezondheidssector komen hierin aan bod.

2. De intramurale gezondheidszorg;

Tot de intramurale gezondheidszorg behoren alle instellingen in de gezondheidszorg (ziekenhuizen, verpleeghuizen, tehuizen, dagverblijven). Daarnaast worden ook de kosten van poliklinische behandelingen, dagverpleging en deeltijdbehandeling tot de intramurale gezondheidszorg gerekend. Uitgesloten worden (de kosten van) de honorering van zelfstandig declarerende specialisten (zie III).

3. De specialistische hulp;

De specialistische hulp omvat de bruto-honorering van zelfstandig declarerende specialisten, inclusief tandheelkundige specialisten (kaakchirurgen, orthodontisten) van zowel poliklinische als klinische behandelingen. De kosten die het gevolg zijn van de behandeling door zelfstandig werkende specialisten (bijvoorbeeld het gebruik van ziekenhuisfaciliteiten) worden gerekend tot de kosten van de intramurale gezondheidszorg. Dit geldt eveneens voor de loonkosten van specialisten die in loondienst zijn.

\section{De geneesmiddelen en kunst- en hulpmiddelen;}

De geneesmiddelen en kunst- en hulpmiddelen betreffen de extramuraal door apothekers en apotheekhoudende huisartsen verstrekte geneesmiddelen op recept en de zelfmedicatie (niet op recept) en de verbandmiddelen. Geneesmiddelenverbruik door intramurale patiënten wordt gerekend tot de kosten van de intramurale sector. Het geneesmiddelengebruik van particulier verzekerden wordt berekend aan de hand van het gebruik van ziekenfondsverzekerden. 


\section{De extramurale gezondheidszorg;}

Tot de extramurale gezondheidszorg behoort de hulp van huisartsen, tandartsen, kruiswerk, kraamzorg en verloskundige hulp, ambulante geestelijke gezondheidszorg en uitwendige geneeskunde (fysiotherapie, oefentherapie, logopedie).

6. De collectieve preventieve zorg;

Het hoofdstuk "collectieve preventieve zorg" heeft betrekking op de gezondheidsbescherming (keuring van waren), basisgezondheidszorg (bevolkingsonderzoek, bestrijding van besmettelijke ziekten, schoolgezondheidszorg, basisgezondheidszorg) en bedrijfsgezondheidszorg. De collectief preventieve taak van het kruiswerk kan niet tot de collectief preventieve zorg worden gerekend, omdat de kosten die hiermee gepaard gaan niet uit te splitsen zijn. Zij vallen dus onder de extramurale gezondheidszorg.

7. Beleid, administratie, beheer, ambulancediensten en overige gezondheidszorg; Tot de kosten van beleid, administratie en beheer behoren de kosten van de zogenaamde "papieren sector", zoals die van ziekenfondsen, de Ziekenfondsraad, particuliere verzekeraars, het ministerie van Welzijn, Volksgezondheid en Cultuur en het Centraal Bureau voor de Statistiek, de Provinciale Raden voor de Volksgezondheid (zie voor een uitgebreidere uiteenzetting hierover later in dit hoofdstuk). Onder "overige gezondheidszorg" wordt verstaan: het zogenaamde zittende ziekenvervoer, laboratoria, medische verzorging van militairen, trombosediensten, medische zorg voor studenten en medische sportkeuring.

Met ingang van het in 1988 verschenen Financieel Overzicht, het zogenaamde Financieel Overzicht Zorg, wordt een nieuwe hoofdstukindeling gehanteerd. De afzonderlijke hoofdstukken representateren zorgsectoren. De indeling ven het Financieel Overzicht Zorg is als volgt.

I Ziekenhuizen en vrijgevestigde specialisten;

Tot de sector "ziekenhuizen" rekent het Financieel Overzicht Zorg algemene, categorale en academische ziekenhuizen.

Tot de "vrijgevestigde specialisten" horen alle zelfstandig werkende medisch specialisten. De loon- en andere kosten van specialisten, die bij ziekenhuizen in dienstverband zijn, zijn begrepen bij de sector "ziekenhuizen".

II Voorzieningen voor geestelijke gezondheidszorg;

De geestelijke gezondheidszorg wordt opgesplitst in drie clusters, namelijk intramurale, semimurale en extramurale voorzieningen. Voorbeelden van de intramurale geestelijke gezondheidszorg zijn de algemene psychiatrische ziekenhuizen, inclusief deeltijd- en poliklinische behandelingen. Semimurale voorzieningen zijn onder meer de Regionale Instellingen voor Beschermd Wonen. Extramurale voorzieningen omvatten Regionale Instellingen voor Ambulante Geestelijke Gezondheidszorg en de Consultatiebureaus voor Alcohol en andere Drugs.

III Voorzieningen voor gehandicapten;

Tot de sector gehandicaptenzorg behoren onder andere tehuizen, dagverblijven en gezinsvervangende tehuizen voor lichamelijk, geestelijk en zintuiglijk gehandicapten.

N Voorzieningen voor ouderen;

Voorzieningen voor ouderen bestaan uit bejaardenoorden en verpleeghuizen.

V Extramurale voorzieningen;

Tot de extramurale voorzieningen behoren de huisarts, het algemeen maatschappelijk werk, de gezinsverzorging, het kruiswerk, de kraamzorg, de verloskundige hulp, de paramedische hulp en de tandarts.

VI Farmaceutische hulp en kunst- en hulpmiddelen;

De categorie "farmaceutische hulp en hulpmiddelen" bevat de extramurale farmaceutische hulp die wordt verstrekt op recept, met inbegrip van verbandmiddelen. 
Collectieve preventieve zorg;

Tot de collectief preventieve zorg wordt gerekend: de gezondheidsbescherming, de basisgezondheidszorg, de bedrijfsgezondheidszorg en het milieubeheer voor zover sprake is van een directe relatie tussen gezondheid en milieu.

\section{Beheer, ziekenvervoer en overig;}

De kosten van beheer zijn de kosten van beleid, beheer en administratie zoals die door overheid, ziekenfondsen, publiekrechtelijke ziektekostenverzekeraars en particuliere verzekeraars worden gemaakt. De categorie "ziekenvervoer" bestaat uit ambulancevervoer, de centrale posten ambulancevervoer, helicoptervervoer en overig ziekenvervoer, inclusief taxivervoer. Tot de post "diversen" behoren tal van (kleine) activiteiten in de zorg, zoals medische zorg voor militairen en studenten, medisch sportkeuring, saneringskosten ziekenhuisvoorzieningen en het preventiefonds.

Een overzicht van de verschillende hoofdstukindelingen in de loop der jaren wordt gegeven in schema 5.2 .

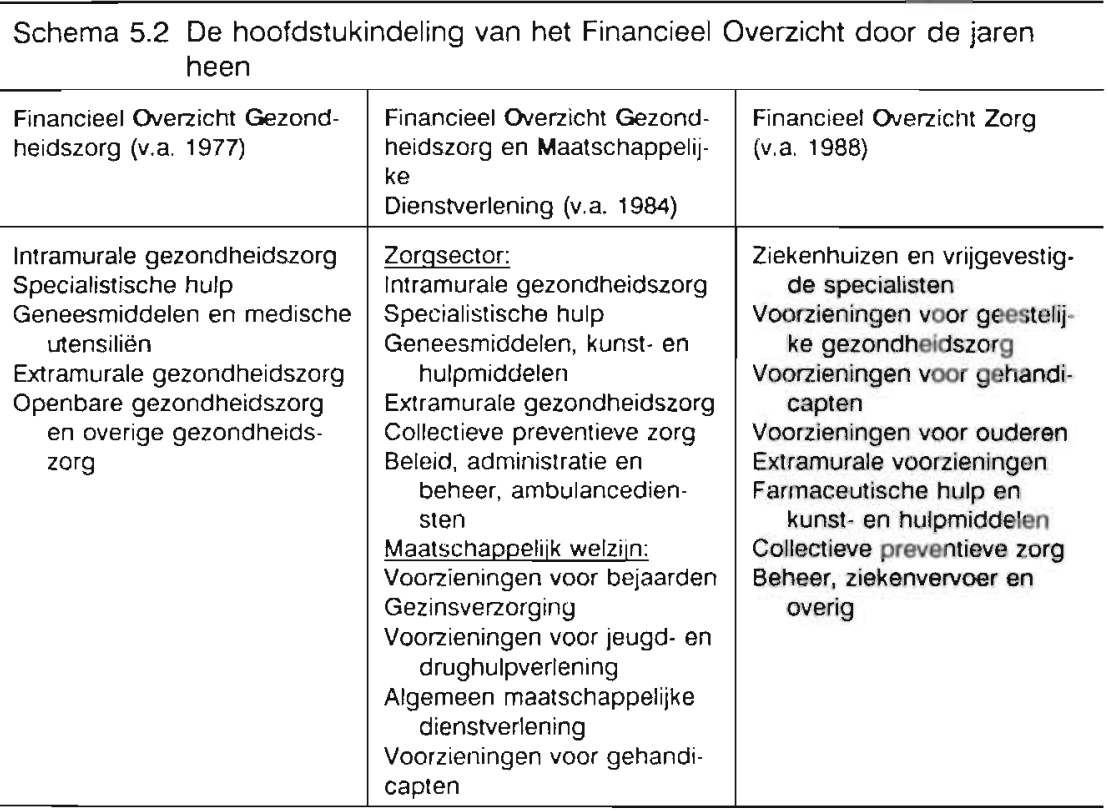

leder van de bovengenoemde hoofdstukken is als volgt opgebouwd. Allereerst komen de kosten aan bod die niet meer te beinvloeden zijn (dat wil zeggen van de afgelopen vijf jaren). Deze zijn onderverdeeld in:

- de definitieve uitkomsten over voorgaande jaren;

- de voorlopige uitkomsten over het jaar, dat vooraf gaat aan het jaar waarin het Financieel Overzicht wordt uitgebracht:

- de raming over het jaar waarin het Financieel Overzicht wordt uitgebracht.

Vervolgens worden de kosten die wel nog te beinvloeden zijn (dat wil zeggen voor de komende vier of vijf jaren) gepresenteerd, uitgesplitst in:

- het financiële kader voor het begrotingsjaar;

- de verkennende raming voor de latere jaren. 
Dit houdt in dat bijvoorbeeld in het Financieel Overzicht van 1990 de definitieve uitkomsten tot en met 1988 zijn opgenomen. Voor 1989 zijn voorlopige uitkomsten gepresenteerd. De cijfers over 1990 betreffen ramingen. Het financieel kader geldt voor 1991 en over 1992 is een verkenning opgenomen.

Schematisch weergegeven levert dit tabel 5.1 op.

Tabel 5.1 Het tijdpad van het Financieel Overzicht

\begin{tabular}{|c|c|c|c|c|c|c|}
\hline Jaar van verschijnen: & 1985 & 1986 & 1987 & 1988 & 1989 & 1990 \\
\hline definitieve uitkomsten $\mathrm{t} / \mathrm{m}$ : & '83 & '84 & '85 & '86 & '87 & '88 \\
\hline voorlopige uitkomsten over: & ' 84 & '85 & '86 & '87 & 88 & '89 \\
\hline raming over: & '85 & '86 & '87 & '88 & '89 & '90 \\
\hline financieel kader voor: & ' 86 & ' 87 & '88 & ' 89 & '90 & '91 \\
\hline verkenning vanaf: & '87 & 88 & '89 & '90 & '91 & '92 \\
\hline
\end{tabular}

Gebaseerd op: Ziekenfondsraad

Advies inzake het $6 e$ financieel overzicht

Amstelveen, 1982

Behalve van een vaste structuur is in de hoofdstukken eveneens sprake van vaste onderwerpen, waarbij steeds wordt uitgegaan van eenzelfde opbouw. Allereerst komt de ontwikkeling van de kosten aan de orde door een overzicht te geven van de input en de output. Input wil hier zeggen het aanbod ofwel de hoeveelheid personeel, het aantal bedden, de apparatuur en andere middelen. Output is het gebruik ofwel het aantal verrichtingen en verpleegdagen, de voorgeschreven geneesmiddelen. Dit vindt plaats door een overzicht te geven van:

- de nominale kosten (de totale exploitatiekosten, uitgesplitst naar categorie van instelling)

- de volume-/capaciteitsontwikkeling (aantal personeelsleden, aantal bedden, personeelsbezetting):

- de loon- en prijsontwikkeling/tariefsontwikkeling (honoraria, vergoeding praktijkkosten, particuliere tarieven, investeringen, afschrijving en interest, personeelskosten);

- het gebruik van voorzieningen (aantal verrichtingen, verpleegdagen, klinisch en poliklinisch gebruik).

Daarna volgt een schets van de financiering van de gezondheidszorg, uitgesplitst naar ziekenfondsverzekering, algemeen fonds bijzondere ziektekosten, particuliere bijdragen en gelden van rijk, provincie en gemeente.

Tenslotte wordt ingegaan op de verwachte toekomstige ontwikkeling met daaraan gekoppeld een raming van de kosten en de financiering.

In het Financieel Overzicht Zorg (vanaf 1988-1989) is de opbouw nauwelijks gewijzigd. Het gaat slechts om een verandering van de kopjes. "Ontwikkeling van de kosten" is bijvoorbeeld "kostenoverzicht" geworden.

\section{\$.2.6 Het Financieel Overzicht en de stelselwijziging}

In aprit 1986 werd de zogeheten "kleine stelselwijziging" ingevoerd. De vrijwillige ziekenfondsverzekering en de bejaardenverzekering werden opgeheven. Dit hield in dat het grootste gedeelte van degenen die vrijwillig bij een ziekenfonds verzekerd 
waren en bejaarden, werden ondergebracht bij de verplichte ziekenfondsverzekering. Het resterende deel van de verzekerden moest zich verzekeren in de particuliere sector. Dit werd geregeld in de Wet op de Toegang tot de Ziektekostenverzekering. Tevens moesten particuliere verzekeraars in het kader van de "kleine stelselwijziging" een bijdrage leveren aan de ziekenfondskas en vond lastenverevening plaats (Knapen, 1992).

De route naar de "grote stelselwijziging" werd ingezet door de Commissie-Dekker, de Commissie Structuur en Financiering Gezondheidszorg. De Commissie Dekker kwam in haar rapport "Bereidheid tot verandering" (1987) met nog verdergaande voorstellen. Zij adviseerde onder meer te komen tot een basisverzekering. Deze basisverzekering zou moeten bestaan uit voorzieningen die op dat moment voor het grootste deel reeds het ziekenfonds- en AWBZ-pakket omvatten. In totaal zou de basisverzekering 85 procent van alle verstrekkingen en voorzieningen in de gezondheidszorg en de maatschappelijke dienstverlening inhouden. Voor het overige deel, waaronder genees-, kunst- en hulpmiddelen, paramedische hulp en tandheelkundige hulp, zouden de verzekerden zich geheel of gedeeltelijk moeten bijverzekeren. De premie van de basisverzekering zou deels naar draagkracht en deels nominaal worden vastgesteld. Binnen het nominale deel zou de mogelijkheid bestaan te kiezen voor een eigen risico. Bovendien zouden voor bepaalde voorzieningen eigen bijdragen worden gevraagd. De centraal geïnde premies zouden terecht komen in een centrale kas. Vandaaruit zouden ze weer worden verdeeld over de verzekeraars met behulp van een verdeelsysteem op basis van objectieve criteria, waardoor risicoselectie door verzekeraars zou worden uitgesloten. Vooruitlopend op het nieuwe stelsel zijn in de loop van de afgelopen jaren de psychiatrie, de gezinszorg en recentelijk de geneesmiddelen alvast onder de AWBZ-financiering gebracht.

In de nota "Werken aan Zorgvernieuwing "(1989-1990) stelt staatssecretaris Simons voor de bestaande verzekeringswetten, te weten de Ziekenfondswet, de Algemene Wet Bijzondere Ziektekosten, de Wet op de Toegang tot de Ziektekostenverzekering, de Wet op de Bejaardenoorden, de ambtelijke ziektekostenregelingen, de Wet Medefinanciering Oververtegenwoordiging Oudere Ziekenfondsverzekerden, de Wet Interne Lastenverevening Particuliere Ziektekostenverzekering. Het nieuwe verzekeringsstelsel zou bestaan uit een verplichte basis- en een vrijwillige aanvullende verzekering. Het basispakket zou bestaan uit een verplichte basis- en een vrijwillige aanvullende verzekering. Het basispakket zou eveneens ongeveer 85 procent van de kosten van de zorgsector, dat wil zeggen gezondheidszorg en maatschappelijke dienstverlening, omvatten. De inning van de premie zou plaatsvinden door de belastingdienst, die deze zou doorsluizen naar een centrale kas. Vanhieruit zou het geld via normuitkeringen, die afhankelijk zouden zijn van het risico van de verzekerde, worden verdeeld over de verzekeraars. Daarnaast zou de verzekerde een inkomensonafhankelijk deel betalen aan de verzekeraar. De verzekeraar bepaalt hiervan zelf de hoogte, hetgeen de onderlinge concurrentie tussen verzekeraars zou moeten verhogen (De Bruin en Schut, 1990). Hierop vooruitlopend zou de vergoeding voor geneesmiddelenverbruik en de huisartsenhulp alvast onder de Algemene Wet Bijzondere Ziektekosten worden gebracht. Dit is echter voorlopig uitgesteld.

Voor het Financieel Overzicht betekent de "kleine stelselwijziging" dat de betekenis van het Financieel Overzicht is afgenomen, aangezien meer verzekerden in de particuliere verzekeringssector terecht zijn gekomen. Hierdoor is formeel het aandeel van het collectief gefinancierde deel (volgens de Ziekenfondswet en de Algemene Wet Bijzondere Ziektekosten) afgenomen en daarmee ook het deel 
heeft.

De "grote stelselwijziging" die een grotere marktwerking beoogt, zou de betekenis van het Financieel Overzicht als taakstellend macro-budget eveneens doen afnemen. Het is echter nog maar de vraag of de overheid na de invoering van de stelselwijziging niet toch de uitgaven voor de zorgsector wil blijven sturen.

\section{$\S 5.3$ De bepaling van de bestuurskosten}

Hiervoor is beschreven welke de doeleinden, het bereik, de status, de totstandkoming en de structuur van het Financieel Overzicht zijn. Hierna komt het hoofdstuk "kosten van beleid, administratie en beheer" van het Financieel Overzicht aan de orde. Daarbij zullen de bestuurskosten worden bepaald. De bestuurskosten zijn gedefinieerd als de kosten van de bestuurlijke infrastructuur bij overheden en particulieren die het gevolg zijn van overheidsbesturing in de gezondheidszorg. $\mathrm{De}$ bestuurskosten, zoals deze worden gepresenteerd in het Financieel Overzicht zijn de kosten van beleid, administratie en beheer. Hiertoe behoren de bestuurskosten van overheden, verzekeraars en adviesorganen. Hier ontbreken de zogeheten verborgen beleidskosten die door instellingen worden gemaakt als gevolg van overheidsbeleid.

Voor de gegevensverzameling zal in eerste instantie het cijfermateriaal uit het hoofdstuk "kosten van beleid, administratie en beheer" worden gebruikt. Daarna zullen aanvullingen worden geput uit begrotingen, jaarverslagen, statistieken en dergelijke van overkoepelende organisaties en het Centraal Bureau voor de Statistiek. Een mogelijk probleem hierbij is de afstemming tussen de diverse bronnen, doordat niet iedereen hetzelfde verstaat onder bestuurskosten.

\section{$\S 5.3 .1$ Het hoofdstuk "kosten van beleid, administratie en beheer"}

De volledige titel van dit hoofdstuk van het Financieel Overzicht luidde tot 1987: "beleid, administratie, ambulancediensten en overige gezondheidszorg". In 1987 werd de titel gewijzigd in "de overige gezondheidszorg" (1987-1988) en in 1988 in "beleid, ziekenvervoer en diversen" (1988-1989). Hier zal echter uitsluitend het gedeelte over de kosten van beleid, administratie en beheer aan de orde komen. De kosten van "ambulancevervoer en overige gezondheidszorg" blijen buiten beschouwing.

Aan het hoofdstuk "kosten van beleid,administratie en beheer" wordt in de eerste Financiële Overzichten weinig aandacht besteed. Het hoofdstuk bestaat aanvankelijk uit slechts een klein aantal onvolledige overzichten met ieder jaar nagenoeg dezelfde bijbehorende tekst. De belangstelling neemt pas toe wanneer vanaf het begin van de jaren tachtig duidelijk wordt dat de kosten van beleid, administratie en beheer een explosieve groei doormaken. Deze interesse wordt groter naarmate de regulering toeneemt, de noodzaak tot bezuinigen duidelijker wordt en de twijfel omtrent de effecten sterker wordt. 

beheer"

De kostenpost "beleid, administratie en beheer" omvat aanvankelijk alleen de kosten van ziekenfondsen, de Ziekenfondsraad, de ziektekostenverzekeraars, het gedeelte van het Ministerie van Volksgezondheid en Milieuhygiëne (later Welzijn, Volksgezondheid en Cultuur) en het Centraal Bureau voor de Statistiek dat aan de gezondheidszorg kan worden toegerekend en de Provinciale Raden voor de Volksgezondheid.

De Ziekenfondsraad onderscheidt in zijn advies van 1982 over het Financieel Overzicht in de post "beleid, administratie en beheer" reeds de categorieën "beheerskosten ziekenfondsen", "kosten heffing en inning premie" en de "kosten van de Ziekenfondsraad en het secretariaat" voor de gelden krachtens de Ziekenfondswet en de categorieën "beheerskosten" en "kosten College voor Ziekenhuisvoorzieningen" voor de uitgaven krachtens de Algemene Wet Bijzondere Ziektekosten. Het Financieel Overzicht geeft deze cijfers dan nog niet afzonderlijk weer.

In het Financieel Overzicht is de post "beleid, administratie en beheer" pas vanaf 1985 enigszins gespecificeerd, namelijk naar "beheerskosten van de ziekenfondsen inclusief de kosten van het secretariaatsbureau van de Ziekenfondsraad" (p. 131). Dit is, volgens het Financieel Overzicht, mogelijk geworden doordat per 1 januari 1984 de budgettering van de beheerskosten van ziekenfondsen is ingevoerd (1985-1986). Met ingang van 1986 zijn ook de kosten van het Centraal Administratie Kantoor AWBZ bij de post "beheerskosten van de ziekenfondsen" gerekend (1986-1987). In het Financieel Overzicht dat in 1987 verschijnt (1987-1988) wordt de post "beleid, administratie en beheer" wat vollediger uitgesplitst. De opgevoerde kostencijfers gaan terug tot 1982.

De opbouw van de post "beleid, administratie en beheer" is als volgt.

- Beheerskosten ziekenfondsen;

Hiertoe rekent men de kosten van gebouwen, de personeelskosten en dergelijke van de ziekenfondsen.

- Kosten Ziekenfondsraad en secretariaat;

Hiertoe behoren alle kosten van de Ziekenfondsraad en het secretariaat van de Ziekenfondsraad.

- Beheerskosten uitvoerende organen Algemene Wet Bijzondere Zektekosten;

Dit zijn de kosten die de ziekenfondsen en particuliere ziektekostenverzekeraars maken bij het uitvoeren van de Algemene Wet Bijzondere Ziektekosten.

- Kosten premie-inning Algemene Wet Bijzondere Ziektekosten en Ziekenfondswet:

Dit is het bedrag dat de Ziekenfondsraad aan de belastingdienst uitkeert voor het innen van de premie.

- College voor Ziekenhuisvoorzieningen;

Hiertoe behoren alle kosten van het College voor Ziekenhuisvoorzieningen, inclusief die van het secretariaat van het College.

- Centraal Orgaan Tarieven Gezondheidszorg;

Hiertoe worden alle kosten van het Centraal Orgaan Tarieven Gezondheidszorg en zijn secretariaat gerekend.

- Beheerskosten overheid;

Dit betreft de kosten van de Provinciale Raden voor de Volksgezondheid, de Inspectie voor de Volksgezondheid en van die delen van het departement van Welzijn, Volksgezondheid en Cultuur en het Rijksinstituut voor Volksgezondheid en Milieuhygiëne die aan de gezondheidszorg kunnen worden toegerekend 
- Beheerskosten particulier;

Dit zijn de beheerskosten van particuliere en publiekrechtelijke ziektekostenverzekeraars, exclusief de kosten van provisies van tussenpersonen.

Uit deze opsomming blijkt hoe breed het begrip bestuurskosten in de gezondheidszorg is, namelijk van de echte uitvoeringskosten van diverse organen (bijvoorbeeld in het geval van de ziekenfondsen en de particuliere verzekeraars) tot de kosten van hele adviesorganen (bijvoorbeeld de Ziekenfondsraad).

In het hoofdstuk "kosten van beleid, administratie en beheer" van het Financieel Overzicht van 1988 blijken verder ook de kosten van de Nationale Raad voor de Volksgezondheid te zijn opgenomen (1988-1989). De hoogte van deze kosten van de Raad zijn voordien echter niet nader gespecificeerd. Dit is op zich vreemd, wanneer men bedenkt dat de kosten van de Nationale Raad en voorheen ook al de Centrale Raad als afzonderlijke post voorkwam op de begroting van het ministerie van Welzijn, Volksgezondheid en Cultuur. Uitsplitsing zou dus best mogelijk zijn geweest, zoals ook gebeurt met de kosten van het College voor Ziekenhuisvoorzieningen en het Centraal Orgaan Tarieven Gezondheidszorg.

\section{§ 5.3.1.2 De totstandkoming van het hoofdstuk "kosten van beleid, administratie en beheer"}

De manier waarop het hoofdstuk "kosten van beleid, administratie en beheer" tot stand komt wordt niet nader verduidelijkt in het Financieel Overzicht. Tot voor kort was er geen aparte rekengroep die zich bezig hield met het hoofdstuk "kosten van beleid, administratie en beheer". Toen was het namelijk de rekengroep "collectieve preventieve zorg" die het hoofdstuk "kosten van beleid, administratie en beheer" erbij deed. Met ingang van het Financieel Overzicht van 1989-1990 is een aparte rekengroep werkzaam op het gebied van de "kosten van beleid, administratie en beheer" en de overige zaken die tot dit hoofdstuk worden gerekend.

In deze rekengroep hebben vertegenwoordigers van de volgende organisaties zitting: het Centraal Bureau voor de Statistiek, de Ziekenfondsraad, het Kontaktorgaan Landelijke Organisaties van Ziektekostenverzekeraars, de Kontaktkommissie Publiekrechtelijke Ziektekostenregelingen voor ambtenaren, de Vereniging van Nederlandse Gemeenten, de Nationale Raad voor de Volksgezondheid, het Centraal Planbureau, het Rijksinstituut voor Volksgezondheid en Milieubeheer, het Centraal Orgaan Tarieven Gezondheidszorg, het Ministerie van Welzijn, Volksgezondheid en Cultuur en van Financiën.

De rekengroep houdt zich bezig met het "beoordelen, afstemmen en verklaren van cijfermatige ontwikkelingen" inzake de kosten van beleid, administratie en beheer (Financieel Overzicht, 1988-1989, p.149). De Ziekenfondsraad, het KLOZ-Informatie Systeem Gezondheidszorg en het Centraal Bureau voor de Statistiek zijn de belangrijkste leveranciers van het cijfermateriaal. Hoe men aan dit materiaal komt, wordt in het Financieel Overzicht niet verantwoord. Navraag heeft geleerd dat dit materiaal is gebaseerd op enquêtes en begrotingen.

Voordat de rekengroep was ingesteld, bleek dat over de bij de verzameling en berekening van de gegevens over de kosten van beleid, administratie en beheer gehanteerde methodieken grote onduidelijkheid heerste. Dit kwam naar voren tijdens een aantal gesprekken met medewerkers van het ministerie, het Centraal Bureau voor de Statistiek, het Centraal Planbureau en het Kontaktorgaan van Landelijke Organisaties van Ziektekostenverzekeraars. 
Ten eerste wist men van elkaar niet hoe de gegevensverzameling (steekproeven, jaarverslagen,) plaatsvond. Systematische uitwisseling van dergelijke informatie ontbrak. Ten tweede bestond weinig inzicht in de gebruikte berekeningsmethodieken. ledere instantie had haar eigen methoden, maar verantwoordde deze niet. Ten derde waren de gehanteerde definities onbekend. Dit betekende dat eenzelfde kostencategorie van verschillende organisaties (bijvoorbeeld de beheerskosten van ziekenfondsen en particuliere ziektekostenverzekeraars) niet vergelijkbaar waren, terwijl dit met enig voorbehoud (bijvoorbeeld rekening houdend met de verschillen in pakketkeuze en in verantwoordelijkheid ten opzichte van ziekenfondsen), tot op zekere hoogte wel mogelijk zou kunnen zijn.

Natuurlijk betekent dit dat men wel vraagtekens kan plaatsen bij de betrouwbaarheid en de validiteit van het cijfermateriaal uit met name de eerste Financiële Overzichten.

Sinds de oprichting van de aparte rekengroep blijken met name de afstemming, de duidelijkheid en de eenheid met betrekking tot de gehanteerde begrippen aanzienlijk te zijn verbeterd, aldus enkele leden van de rekengroep.

Navraag heeft geleerd dat de gegevensverzameling per kostencategorie als volgt geschiedt:

\section{- Beheerskosten ziekentondsen;}

Door alle beheersbudgetten van alle ziekenfondsen bij elkaar op te tellen ontstaat het totaaloverzicht van alle beheerskosten van de ziekenfondsen. Aangezien deze kosten met ingang van 1 januari 1984 zijn gebudgetteerd, is de omvang hiervan bekend.

\section{- Ziekenfondsraad;}

De Ziekenfondsraad verstrekt deze gegevens zelf. Zij zijn terug te vinden in de jaarverslagen van de Raad.

- Uitvoerende organen Algemene Wet Bijzondere Ziektekosten;

De ziekenfondsen en de particuliere ziektekostenverzekeraars krijgen voor de uitvoering van de Algemene Wet Bijzondere Ziektekosten een vergceding van het Centraal Administratie Kantoor AWBZ. Al deze vergoedingen worden gelijk gesteld aan de kosten, bij elkaar opgeteld en leveren tezamen de post "uitvoerende organen Algemene Wet Bijzondere Ziektekosten".

- Premie-inning Algemene Wet Bijzondere Ziektekosten en Ziekenfondswet;

De vergoeding die de Ziekenfondsraad betaalt aan de belastingdienst voor het innen van de premie vormt deze post.

- College voor Ziekenhuisvoorzieningen;

Hiertoe behoort de hele jaarrekening van dit College. De totale kosten zijn geboekt op de begroting van het Ministerie van Welzijn. Volksgezondheid en Cultuur. Deze post is dus op de rijksbegroting terug te vinden.

\section{- Centraal Orgaan Tarieven Gezondheidszorg;}

Hiervoor geldt hetzelfde als voor de post "College voor Ziekenhuisvoorzieningen".

- Overheid;

Het Centraal Bureau voor de Statistiek verzamelt en levert de gegevens voor de categorie "overheid". Deze categorie wordt gedestilleerd uit de begroting van het ministerie van Welzijn, Volksgezondheid en Cultuur. De uitgaven van de provincies en de gemeenten voor "volksgezondheid" worden gedeeltelijk meegenomen. Informatie omtrent wat wel en wat niet wordt meegerekend ontbreekt.

\section{- Particulier:}

Tot voor kort berekende het Centraal Bureau voor de Statistiek deze kosten door van alle particuliere verzekeraars (dus ook van schadeverzekeraars en dergelijke) de zogenaamde produktiekosten (dat wil zeggen alle kosten behalve de uitgekeerde of uit te keren vergoedingen en de winst) te bepalen. Dit vond plaats aan de hand van de rekeningen. Vervolgens bepaalde het Centraal Bureau voor de 
Statistiek welk deel hiervan voor de gezondheidszorg bestemd was. Op basis hiervan berekende men de beheerskosten van de particuliere verzekeraars. Het betrof dus een schatting. Sinds kort levert het KLOZ-Informatie Systeem Gezondheidszorg de gegevens. Deze zijn ontleend aan marktenquêtes van het Centrum voor Verzekeringsstatistiek.

Nadat de gegevens zijn verzameld, stemt de rekengroep de definities op elkaar af en brengt het geleverde cijfermateriaal op éen lijn. Het zou meer voor de hand liggen om eerst de definities op elkaar af te stemmen. Maar door de vele verschillende bronnen gebeurt dit achteraf pas. Daarna schrijft het ministerie de bijbehorende teksten en het beleidsmatige gedeelte. De teksten komen voor verantwoording van het ministerie. De rekengroep staat hierbuiten.

Wanneer men de hoofdstukken "kosten van beleid, administratie en beheer" van de Financiële Overzichten bekijkt, valt op dat veelvuldig statistische (bijvoorbeeld 1982 1983; 1983-1984; 1984-1985) en andere correcties (zoals 1987-1988) worden doorgevoerd. Niet altijd blijkt wat deze correcties inhouden en tot welke veranderingen in de kosten zij hebben geleid.

Concluderend kan men echter wel stellen dat tegenwoordig meer aandacht wordt besteed aan de gegevensverzameling en het cijfermateriaal. Hierdoor lijkt de betrouwbaarheid te zijn toegenomen.

\section{§5.3.1.3 De hoogte van de kosten van beleid, administratie en beheer}

Zoals ook al in hoofdstuk 1 is opgemerkt zijn de kosten van beleid, administratie en beheer vanaf het begin van de jaren zeventig explosief gestegen. Dit geldt niet alleen voor de absolute getallen, maar ook relatief als percentage van de totale kosten van de gezondheidszorg en ten opzichte van 1985 (zie tabel 5.2). De gegevens uit tabel 5.2 zijn afkomstig van het Centraal Bureau voor de Statistiek en niet van het Financieel Overzicht, aangezien in het Financieel Overzicht in de loop der jaren de hoofdstukindeling veelvuldig is gewijzigd. Het uitgangspunt is het prijspeil van 1985; alle andere kosten zijn hieraan gerelateerd. Hierdoor is vergelijking over een twintigtal jaren onmogelijk. Overigens is gebruik gemaakt van cijfermateriaal van het Centraal Bureau voor de Statistiek aangezien in het Financieel Overzicht de hoofdstukindelingen zo vaak veranderen dat vergelijking over een aantal jaren nauwelijks mogelijk is. 
Tabel 5.2 De procentuele stijging van de kosten van beleid, administratie en beheer in verhouding tot de andere sectoren (in constante prijzen; prijspeil 1985, ten opzicht van 1985)

\begin{tabular}{|c|c|c|c|c|c|c|c|c|c|c|c|}
\hline & 1972 & 1974 & 1976 & 1978 & 1980 & 1982 & 1984 & 1985 & 1986 & 1988 & $1990^{\prime \prime}$ \\
\hline intramuraal & 86 & 90 & 94 & 96 & 98 & 98 & 99 & 100 & 103 & 107 & 117 \\
\hline extramuraal & 68 & 73 & 75 & 82 & 90 & 94 & 97 & 100 & 104 & 109 & 115 \\
\hline geneesmidd. & 66 & 71 & 75 & 80 & 83 & 91 & 95 & 100 & 109 & 125 & 146 \\
\hline $\begin{array}{l}\text { boloid, admi- } \\
\text { nistratie en } \\
\text { boheer }\end{array}$ & 54 & 60 & 65 & 68 & 79 & 87 & 90 & 100 & 110 & 111 & 127 \\
\hline overig & 92 & 96 & 99 & 106 & 110 & 110 & 111 & 100 & 98 & 108 & 109 \\
\hline total & 78 & 82 & 85 & 89 & 93 & 96 & 98 & 100 & 104 & 110 & 122 \\
\hline
\end{tabular}

-... schatting

Bron: Kosten en financiering van de gezondheidszorg 1972-1968, 1990 Centraal Bureau voor de Statistiek Voorburg, 1991, 1992

De algemene trend in tabel 5.2 is dat alle posten stijgen. De post geneesmiddelen is het meest gestegen, op de voet gevolgd door de kosten van beleid, administratie en beheer. De stijging is het grootst geweest voor 1985; hierna heeft een afvlakking van de groei plaatsgevonden.

Met name de Nationale Raad voor de Volksgezondheid laat vanaf 1983 ieder jaar opnieuw zijn bezorgdheid blijken over de sterke stijging van de kosten van beleid, administratie en beheer.

In diverse publikaties worden verschillende oorzaken aangevoerd voor de sterke stijging (en vaak ook verschuiving) van de kosten van beleid, administratie en beheer. Daarbij is een onderscheid mogelijk tussen beleidsmatige oorzaken enerzijds en methodisch-technische oorzaken anderzijds.

Beleidsmatige oorzaken zijn de volgende.

- Het overheidsbeleid, in gang gezet met het verschijnen van de Structuurnota;

Dit beleid was bedoeld om van de gezondheidszorg een geïntegreerd, samenhangend, doelmatig, overzichtelijk en voor een ieder toegankelijk stelsel van gezondheidszorgvoorzieningen te maken. Daartoe diende onder meer een instrumentarium te worden gecreeerd met behulp waarvan de voorzieningen beter op elkaar konden worden afgestemd, de aanwas en veranderingen in het systeem beter gepland en de kosten van de zorgverlening beheerst en bewaakt. Om dit te bereiken is onder meer de Wet Voorzieningen Gezondheidszorg afgekondigd. Herhaaldelijk wordt aangevoerd dat de gestegen kosten van beleid, administratie en beheer een gevolg zijn van een omvangrijke taakverzwaring. Deze taakverzwaring is "een gevolg van het streven naar grotere beheersing van de kostenontwikkeling in de sektor van de gezondheidszorg" (Financiële Overzichten, 1984-1985; 1985-1986; 1986-1987; 1987-1988). In plaats van kostenbeheersing betekende zelfs gedeeltelijke invoering van beide wetten echter al een aanzienlijke toename van de kosten bij gemeenten en provincies. In diverse Financiële Overzichten wordt gesproken over een "beperkte" groei van de kosten met circa $f 6$ miljoen als gevolg van de invoering van de Wet Ziekenhuisvoorzieningen en de Wet Voorzieningen Gezondheidszorg (onder andere Financieel Overzicht, 1987-1988).

Bovendien zijn, als gevolg van de invoering van de Wet Tarieven Gezondheidszorg en de daarop gebaseerde budgettering, eveneens de beheerskosten toegenomen (Financieel Overzicht, 1988-1989). 
Bovengenoemde wetten noodzaken, met andere woorden, lagere overheden, verzekeraars, instellingen, tot het maken van extra bestuurskosten.

- De verschillende wijzen van financiering en van administratieve verwerking;

$\mathrm{Er}_{\mathrm{r}}$ is een aanzienlijk verschil in betalingssystematiek volgens het regime van de Algemene Wet Bijzondere Ziektekosten, de Ziekenfondswet en de particuliere ziektekostenverzekeraars. Als gevoig hiervan verschillen eveneens de te voeren administratieve handelingen door de instellingen van gezondheidszorg, het verbindingskantoor respectievelijk het ziekenfonds en de particuliere ziektekostenverzekeraars (Nationale Raad voor de Volksgezondheid, 1986). Krachtens de Algemene Wet Bijzondere Ziektekosten worden instellingen in hun geheel gefinancierd. Dit in tegenstelling tot de werkwijze volgens de Ziekenfondswet en in de particuliere sector, waarbij per ziekenfonds casu quo per particuliere verzekeraar voor iedere afzonderlijke patiënt en iedere afzonderlijke behandelingen apart betaald moet worden. Overigens is rekening gehouden met een incidentele uitgave van $f 11$ miljoen aan beheerskosten bij de ziekenfondsen ter compensatie van de administratiekosten, voortvloeiend uit de invoering van de eigen bijdrage-regeling voor ziekenfondsverzekerden wanneer zij aanspraak maken op specialistische hulp (Financieel Overzicht, 1988-1989).

\section{- De taakverzwaring voor de ziekenfondsen en de particuliere ziektekostenver- zekeraars;}

Vanaf het begin van de jaren tachtig doet zich een taakverzwaring voor bij de financiers. Sedent 1982 zijn deze namelijk betrokken bij het overleg omtrent de vaststelling van de tarieven. Dit is het directe gevolg van de invoering van de Wet Tarieven Gezondheidszorg, die overigens eveneens bedoeld is om "een beheersing van de kostenontwikkeling in de gezondheidszorg te bereiken", aldus een toelichting in het Financieel Overzicht (1983-1984, p.96).

\section{- AWBZ-financiering gezinszorg;}

Per 1 januari 1989 komt de gezinszorg niet meer voor rekening van Welzijn, Volksgezondheid en Cultuur. Financiering vindt vanaf dat tijdstip plaats uit de Algemene Wet Bijzondere Ziektekosten. Hierdoor doet zich een verschuiving voor van de beheerskosten van de overheid naar de Algemene Wet Bijzondere Ziektekosten (Financieel Overzicht, 1988-1989).

Methodisch-technische oorzaken die worden aangevoerd zijn de volgende.

- Incidenteel door de aankoop van gebouwen en verhuizing;

In 1986 heeft de overheid gebouwen aangekocht voor de Keuringsdienst van Waren en is het Directoraat-Generaal voor de Volksgezondheid verhuisd. De hiermee gemoeide kosten zijn incidenteel opgevoerd in het Financieel Overzicht (1987-1988).

- "Nieuwe inzichten" bij het berekenen van de kosten;

Met name bij de post "overheid" wordt een toename van de kosten van beleid, administratie en beheer regelmatig toegeschreven aan nieuwe berekeningsmethodieken (zie bij voorbeeld Financieel Overzicht, 1987-1988). Dit geldt overigens eveneens voor de post "particulier" (zie onder andere Financieel Overzicht, 19821983).

\section{- De toevoeging van begrotingsartikelen;}

In het Financieel Overzicht van 1988 (1987-1988) blijkt een aantal begrotingsartikelen te zijn toegevoegd aan de post "overheid", hetgeen statistische correcties tot gevolg heeft, waardoor de kosten van beleid, administratie en beheer stijgen. 
Behalve een aanzienlijke stijging in de kosten van beleid, administratie en beheer, valt ook een drastische toename van het aantal bezette arbeidsplaatsen te constateren (zie tabel 5.3). Ook dit geldt zowel in absolute aantallen als relatief ten opzichte van 1979. De stijging is de afgelopen jaren echter wat afgevlakt.

Tabel 5.3 Het aantal bezette arbeidsplaatsen in de sector "beleid, administratie en beheer" (absoluut en met 1979 als index)

\begin{tabular}{l|lllllllll}
\hline & 1979 & 1980 & 1981 & 1982 & 1983 & 1984 & 1985 & 1986 & $1987^{*}$ \\
\hline abs. & 10.629 & 11.167 & 12.115 & 12.804 & 13.404 & 14.069 & 14.386 & 14.716 & 14.775 \\
rel. & 100 & 105 & 114 & 120 & 126 & 132 & 135 & 138 & 139 \\
\hline
\end{tabular}

* = raming van 1988

Gebaseerd op: Financiéle Overzichten 1986 Vm 1991

Zie verder paragraaf 5.3.2.3 omtrent het aantal arbeidsplaatsen in de bestuurlijke sector van de gezondheidszorg.

Volgens de Nationale Raad gaf de sector beleid, administratie en beheer in de periode 1979 tot 1984 een stijging te zien van 32,4 procent in termen van arbeidsplaatsen. Hiertegenover staat een stijgingspercentage van 10,4 procent voor de totale gezondheidszorg. Binnen de beleidssector was de stijging van het aantal arbeidsplaatsen bij de ziekenfondsen het grootst, namelijk 37,3 procent (Nationale Raad voor de Volksgezondheid, 1987).

Hiermee is het argument uit het Financieel Overzicht weerlegd dat de stijging van de kosten van beleid, administratie en beheer het gevolg zou zijn van allerlei bijstellingen, correcties, incidentele investeringen en andere meer en minder gerechtvaardigde oorzaken. Immers, wanneer men de tabellen 5.3 (het aantal bezette arbeidsplaatsen in de bestuurlijke sector) en 5.2 (de kosten van beleid, administratie en beheer) met elkaar vergelijkt, dan blijkt het volgende: het aantal bezette arbeidsplaatsen stijgt weliswaar minder snel dan de kosten, maar deze stijging is toch nog aanzienlijk. Hierdoor lijkt de conclusie gerechtvaardigd dat in ieder geval een groot deel van de stijging van de kosten van beleid, administratie en beheer is toe te schrijven aan een stijging van het aantal arbeidsplaatsen in deze sector (zie verder paragraaf 5.3.2.3).

Om de toename van de kosten van beleid, administratie en beheer een halt toe te roepen is een aantal maatregelen getroffen.

- Bureaucratiekorting;

Parallel aan het ambtenarenbeleid van de regering geldt voor de periode van 1988 tot 1990 een bureaucratiekorting van $f 2,6$ miljoen per jaar. Deze ontbureaucratiseringskorting geldt voor de kosten van de adviesorganen in de gezondheidszorg (Financieel Overzichten, 1987-1988; 1988-1989).

\section{- Budgettering beheerskosten ziekenfondsen.}

Toen bleek dat de beheerskosten van de ziekenfondsen bleven stijgen heeft de regering daaraan een einde willen maken door deze kosten met ingang van 1 januari 1984 te budgetteren. Dit budget is vastgesteld op basis van de gemaakte kosten op 31 december 1983 en met een eenmalig gecreëerde ruimte ter dekking van in 1983 aangegane verplichtingen die in 1984 en latere jaren tot kosten zullen leiden. Voor 1984 is rekening gehouden met gestegen lonen en prijzen; voor 1985 bovendien met inschalings- (of anciëniteits-) effecten, huur en huisvestingskosten. 
Daarbovenop is ieder jaar een structurele korting doorgevoerd (Nationale Raad voor de Volksgezondheid, 1987).

Een en ander heeft overigens niet onmiddellijk geleid tot een reductie van de beheerskosten van de ziekenfondsen. Een aanzienlijk lager groeitempo kan wel worden geconstateerd. Naijlingseffecten worden hievan als oorzaak genoemd.

Concluderend kan men stellen dat de bestuurskosten in de loop der jaren als maar zijn gestegen. Hoewel dit door beleidsmakers is onderkend, zijn de getrofien maatregelen niet afdoende gebleken. De bestuurskosten bleven stijgen.

\section{§ 5.3.1.4 De verdeling van de kosten van beleid, administratie en beheer}

Over de verdeling van de kosten van beleid, administratie en beheer over overheden, instellingen en financiers bestaat reeds lang onduidelijkheid. De specificatie van dit hoofdstuk van het Financieel Overzicht is altijd gering geweest. Het heeft tot 1985 (Financieel Overzicht, 1985-1986) geduurd voordat deze kosten enigszins werden uitgesplitst. Deze specificatie betrof de beheerskosten van de ziekenfondsen. Pas sedert het Financieel Overzicht van 1987 (Financieel Overzicht, 1987-1988) vindt onderverdeling naar acht kostenposten plaats. Deze cijfers gaan terug tot 1982. De Ziekenfondsraad verschaft reeds vanaf 1984 een overzicht van de kosten van beleid, administratie en beheer, zij het dat het hier vanzelfsprekend uitsluitend om de beheerskosten gaat die gemaakt worden krachtens de Ziekenfondswet en de Algemene Wet Bijzondere Ziektekosten. Beide bronnen combinerend geeft dit het volgende beeld te zien van de verdeling van de kosten van beleid, administratie en beheer naar kostenmaker (zie tabel 5.4). 
Tabel 5.4 De verdeling van de kosten van beleid, administratie en beheer naar kostenmaker (in miljoenen guldens)

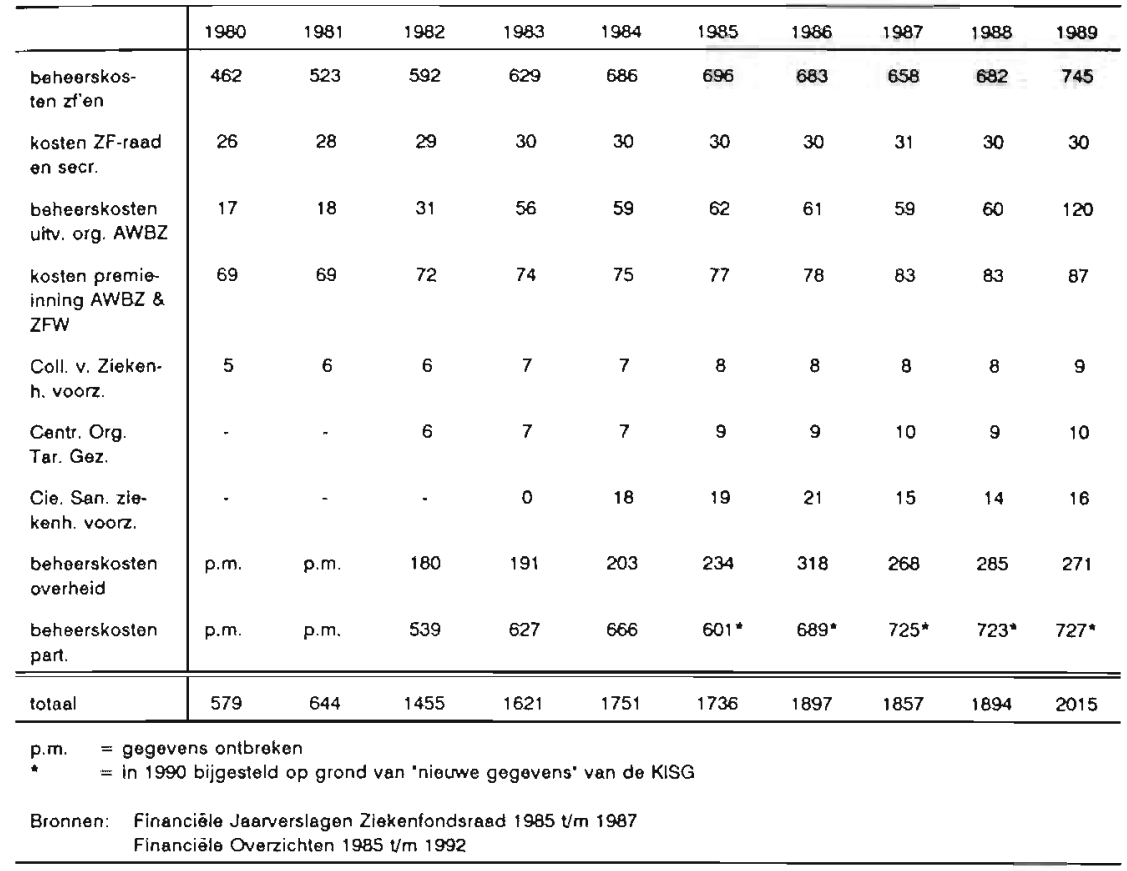

Uit tabel 5.4 blijkt dat verreweg het grootste deel van de kosten van beleid, administratie en beheer bestaat uit de beheerskosten van de ziekenfondsen en van de particuliere ziektekostenverzekeraars. Hierna volgen de beheerskosten van de overheid. Een sterke stijging heeft zich eveneens voorgedaan bij de beheerskosten van de beide verzekeraars. Ditzelfde kan worden gezegd over de beheerskosten van de overheid.

Gespecificeerd naar financieringsbron levert de verdeling van de kosten van beleid, administratie en beheer naar de financieringsbron dan levert dit figuur 5.1 op. 
Figuur 5.1 De verdeling van de kosten van beleid, administratie en beheer naar financieringsbron

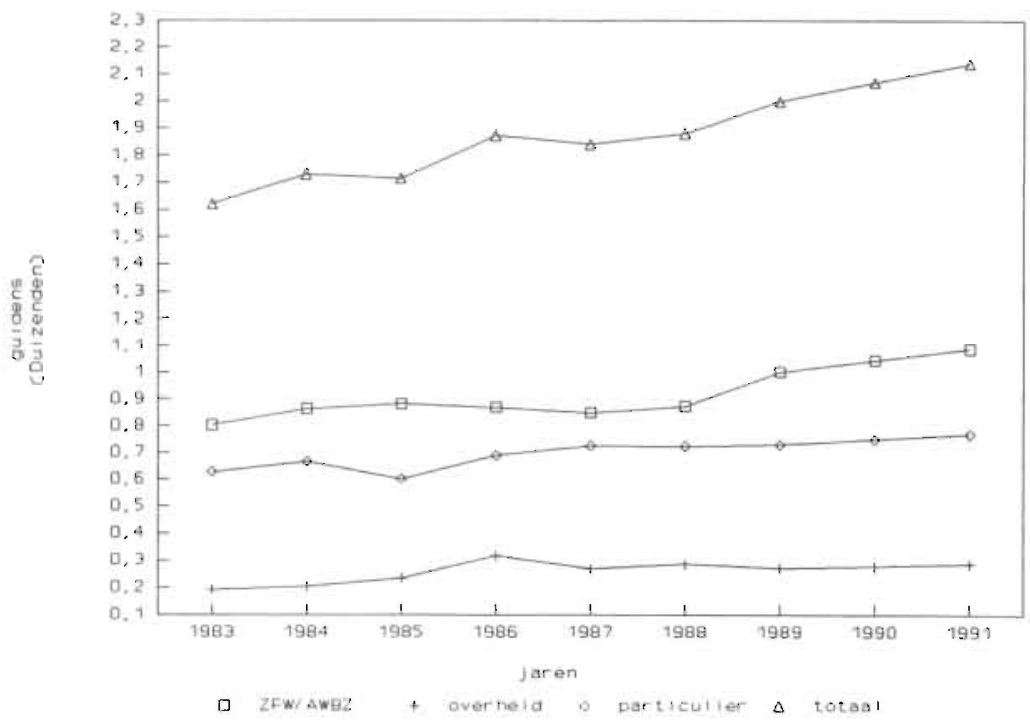

Opvallend is dat de ziekenfondsen en de particuliere verzekeraars samen het grootste deel (namelijk 85 tot 90 procent) van de financiering van de kosten van beleid, administratie en beheer voor hun rekening nemen. De beheerskosten bij de overheid zijn echter eveneens aanzienlijk. Zoals reeds eerder opgemerkt worden onder andere de taakverzwaring en de financieringswijze aangemerkt als oorzaken voor de hoogte van de beheerskosten bij de verzekeraars. Een bijkomend probleem lijkt de schaalvergroting door fusies van de verzekeraars. Want hoewel schaalvergroting vaak wordt beschouwd als een kostenbesparende maatregel, is het ook een feit dat grotere organisaties bureaucratische kenmerken vertonen en hogere transactiekosten (zie paragraaf 3.2) genereren.

Interessant is voorts een overzicht van het aandeel van de beheerskosten in de kosten van verstrekkingen per ziekenfondsverzekerde en per particulier verzekerde (zie tabel 5.5). Hieruit blijkt namelijk dat de beheerskosten per particulier verzekerde bijna twee maal zo hoog zijn als de beheerskosten per ziekenfondsverzekerde. 
Tabel 5.5 De beheerskosten per ziekenfonds- en per particulier verzekerde (in guldens)

\begin{tabular}{l|lllllllllll}
\hline & 1980 & 1981 & 1982 & 1983 & 1984 & 1985 & 1986 & 1987 & 1988 & 1989 & 1990 \\
\hline zf & 47,7 & 53,8 & 61,1 & 65,1 & 71,3 & 72,2 & 76,5 & 73,1 & 75,7 & 83,4 & 81,9 \\
p & p.m. & p.m. & 114,7 & 130,9 & 137,6 & 123,2 & 125,5 & 130,6 & 132,4 & 152,8 & 152,5 \\
\hline
\end{tabular}

p.m. = gegevens ontbreken

Gebaseerd op: Financièle Overzichten $1985 \mathrm{t} / \mathrm{m} 1991$

Financiële Jaarverslagen Ziekenfondsraad $1981 \mathrm{t} / \mathrm{m} 1991$

KLOZ Informatiesysteem Gezondheidszorg, Houten 1988 en 1989

Enkele kanttekeningen ten aanzien van de vergelijkbaarheid van de gegevens moeten wel worden gemaakt. In de eerste plaats is in de particuliere sector, in tegenstelling tot de ziekenfondssector, sprake van provisie voor tussempersonen. Bovendien kennen de particuliere verzekeraars een grotere produktdifferentiatie dan de ziekenfondsen. In de tweede plaats is men in de private sector terughoudender om de exacte beheerskosten bekend te maken, gezien de concurrentieverhoudingen.

Feit is dat de de beheerskosten per verzekerde blijven stijgen. De beheerskosten per ziekenfondsverzekerde zijn in de loop van tien jaren zelfs bijna verdubbeld.

Over de beheerskosten van de overheid, tenslotte, is weinig concreets te zeggen. Deze kosten stijgen weliswaar steeds, maar het is niet duidelijk door welke factoren deze stijging wordt verklaard. Ten eerste worden veelvuldig "statistische correcties" doorgevoerd (waartoe is niet duidelijk). Ten tweede wordt in de Financiële Overzichten niet duidelijk gemaakt welke kosten wel en welke niet worden meegerekend. Men kan dus alleen maar concluderen dat de beheerskosten bij de overheid blijven stijgen (het niveau van de kosten voor 1989 is weliswaar lager dan voor 1988, maar dit zal nog wel worden bijgesteld).

\section{§5.3.2 Aanvullingen op het hoofdstuk "kosten van beleid, administratie en beheer" in guldens}

Men kan het Financieel Overzicht bekritiseren ten aanzien van onderschatting van de kostenpost "beleid, administratie en beheer". De post beperkt zich tot de bestuurskosten van de sector van de verzekeraars, adviesorganen en overheden. In de intramurale, extramurale en preventieve sector doen zich echter ook bostuurskosten voor, alleen blijkt dat niet uit de Financiële Overzichten. Immers, de bestuurskosten van bijvoorbeeld de intramurale sector zijn opgenomen ("verborgen", zou men kunnen zeggen) in het hoofdstuk "kosten van de intramurale gezondheidszorg". Een deel van deze kosten is echter eveneens het gevolg van besturing. Wanneer men echter de kosten van algemeen personeel zonder meer beschouwt als de bestuurskosten in de intramurale zorg, is sprake van vervuiling van het begrip bestuurskosten. Het validiteitsprobleem betreft hier een overschatting van de bestuurskosten. Voor de interne beheer van instellingen is immers ook een zekere hoeveelheid kosten noodzakelijk. Dit gedeelte zou in principe buiten beschouwing moeten blijven. Maar aangezien het onmogelijk is na te gaan om welke bedragen het hier exact gaat, zal dit in deze studie niet gebeuren. 
De bestuurskosten in de gezondheidszorg zijn overigens lang niet allemaal te wijten aan regelingen die uitsluitend binnen deze sector gelden. Wettten, zoals de Kernenergiewet, de Arbeidsomstandighedenwet en de Wet op de Ondernemingsraden, zijn eveneens van toepassing op gezondheidszorginstellingen.

De Nationale Raad heeft het probleem van de onvolledigheid van het hoofdstuk "kosten van beleid, administratie en beheer" herhaaldelijk gesignaleerd in zijn adviezen (voor het eerst in 1983). Er werd toen echter aan toe gevoegd dat verbijzondering van deze kosten niet mogelijk zou zijn in verband met de gehanteerde registratiemethoden. Dit argument is evenwel achterhaald, aangezien het, althans voor een aantal categorieën, wel mogelijk is de bestuurskosten af te leiden. Dit is met name het geval bij de intramurale gezondheidszorg en het kruiswerk. Voor de provincie en de gemeente zou het ook mogelijk moeten zijn. Echter, de gegevens die het Centraal Bureau voor de Statistiek hieromtrent verzamelt, blijken niet betrouwbaar te zijn. Niet alle provincies en gemeenten verstaan blijkbaar hetzelfde onder "gezondheidszorg" en onder "beheer". Het lijkt alleszins de moeite waard hierin verbetering aan te brengen. Voor de overige sectoren is het helaas niet mogelijk om met het op dit moment beschikbare cijfermateriaal aanvullingen aan te brengen, aangezien de gegevens hieromtrent ontbreken. Inzicht in hetgeen bijvoorbeeld in de rest van de extramurale sector aan bestuurskosten wordt besteed, blijft dus afwezig. In de extramurale sector werken immers voornamelijk individuele hulpverleners, zoals huisartsen, tandartsen en fysiotherapeuten. Gegevens over de bestuurskosten die zij maken, zijn niet beschikbaar

Op grond van pragmatische overwegingen, namelijk het beschikbaar zijn van gegevens, is gekozen voor de intramurale gezondheidszorg en het kruiswerk om van deze segmenten van de gezondheidszorg de bestuurskosten te achterhalen. Aangezien echter alleen al de intramurale gezondheidszorg 60 procent van de kosten van de totale gezondheidszorg vormt, wordt daarmee toch al een aanzienlijke correctie aangebracht in het hoofdstuk "kosten van beleid, administratie en beheer" en worden de bestuurskosten benaderd.

Aan de hand van de "Financiële Statistiek in de instellingen van intramurale gezondheidszorg" van het Nationaal Ziekenhuisinstituut en de uitgave "Intramurale gezondheidszorg in Nederland" van het Centraal Bureau voor de Statistiek kan worden afgeleid hoe hoog de bestuurskosten in de gehele intramurale sector zijn. Beide instanties hanteren immers binnen de personeelskosten de categorie "algemeen personeel". Hieronder zijn de volgende subcategorieën begrepen: "directie; administratief en automatiseringspersoneel; civiel, technisch en agrarisch personeel; personeel geestelijke verzorging; opleidingspersoneel; organisatiepersoneel en het resterend overig algemeen personeel". Het probleem dat zich voordoet bij de bepaling van de bestuurskosten is het feit dat niet alle kosten van deze categorieën zijn toe te schrijven aan bestuur. Bepaalde kosten zijn toe te schrijven aan interne beleidsvoering, de administratie en registratie van medische handelingen. Dit is niet geheel te herleiden tot bestuur. Dit soort vervuiling van de bestuurskosten is echter met de beschikbare statistieken niet of nauwelijks te corrigeren. Daarom worden hier voor een deel de bestuurskosten weergegeven, die wel de kosten die het gevolg zijn van besturing in het algemeen en ook de kosten van het interne beheer omvatten.

De getallen van 1980 tot 1988 (recentere gegevens zijn nog niet voorhanden) zijn bijeengebracht in tabel 5.6 . 
Tabel 5.6 Bestuurskosten in instellingen van intramurale gezondheidszorg (in miljoenen guldens)

\begin{tabular}{l|lllllllll}
\hline & 1980 & 1981 & 1982 & 1983 & 1984 & 1985 & 1986 & 1987 & 1988 \\
\hline $\begin{array}{l}\text { Alg. } \\
\text { pers. }\end{array}$ & 1.905 & 2.029 & 2.169 & 2.191 & 2.122 & 2.212 & 2.449 & 2.474 & 2.500 \\
\hline
\end{tabular}

Bronnen: Nationaal Ziekenhuisinstituut

Financiële statistiek in de instellingen van intramurale gezondheidszorg

De intramurale gezondheidszorg in cijfers

Utrecht, $1980 \mathrm{t} / \mathrm{m} 1990$

Uit tabel 5.6 blijkt dat de bestuurskosten ook in de intramurale sector stijgen ook a! is deze stijging niet zo sterk als de stijging van de beheerskosten van de verzekeraars. Mogelijke oorzaken van de toename van de bestuurskosten in intramurale instellingen zijn de eisen die aan de instellingen worden gesteld in verband met budgettering, gegevensverwerking, automatisering, fusies, inventarisaties, adviezen, enquêtes en dergelijke. Ook op de intern beheer moet in dit verband worden gewezen. Al deze zaken nopen de instellingen tot het opzetten van een steeds zwaardere bestuurlijke en administratieve infrastructuur. Voor de toenmalige Centrale Raad was deze ontwikkeling in 1982 reeds aanleiding om te waarschuwen voor een situatie "waarbij achter elke direct-patiënt-gebonden-werker een administratief werker komt te functioneren" (1982, p.59). Zo dramatisch is de situatie nog niet. Tussen 1980 en 1988 schommelt het percentage "indirecte" werkers tussen 30 en 28 procent (in full time equivalents) van het totale aantal bezette arbeidsplaatsen in de intramurale gezondheidszorg.

De conclusie luidt dat het, zij het met enige kanttekeningen, mogelijk is in het hoofdstuk "kosten van beleid, administratie en beheer" van het Financieel Overzicht ook de bestuurskosten van de intramurale sector op te nemen.

Aan de hand van de jaarverslagen van de Nationale Kruisvereniging kan men afleiden hoe hoog de kosten van de zogenaamde "indirecte zorg" zijn. Binnen de indirecte zorg wordt onderscheid gemaakt tussen "directie en staf", "administratieve functies" en "beheer". Tot de "directie en staf" behoren eveneens de districtsverpleegkundigen, de verpleegkundigen in algemene dienst en de artsen voor de sociaal-medische dienst. Tot de "directe functies" behoren: hoofdwijkverpleegkundigen, wijkverpleegkundigen, wijkziekenverzorgenden, diëtisten en consultatiebureauartsen. De gegevens die in de jaarverslagen vermeld worden zijn echter niet compleet. Met het oog hierop zijn de benodigde getallen afgeleid uit de statistieken van het Centraal Bureau voor de Statistiek. In tabel 5.7 wordt een overzicht gegeven van de indirecte personeelskosten in het Kruiswerk.

Tabel 5.7 De indirecte personeelskosten in het Kruiswerk (in miljoenen guldens)

\begin{tabular}{l|ccccccccc}
\hline & 1980 & 1981 & 1982 & 1983 & 1984 & 1985 & 1986 & 1987 & 1988 \\
\hline Dir. en staf & 11 & 12 & 13 & 14 & 15 & 18 & 22 & 25 & 26 \\
$\begin{array}{l}\text { Tot. pers. } \\
\text { kost. }\end{array}$ & 407 & 441 & 494 & 526 & 538 & 576 & 615 & 633 & 655 \\
\hline
\end{tabular}

Gebaseerd op: Centraal Bureau voor de Statistiek

Kosten en financiering van de gezondheidszorg 1972-1988, 1991 
Ook tabel 5.7 geeft aan dat de indirecte personeelskosten in het Kruiswerk zijn gestegen.

In de Meerjarenraming van 1989 geeft de Nationale Kruisvereniging aan dat, uitgaande van het totale aantal formatieplaatsen werkzaam binnen de kruisorganisaties, de verhouding tussen de direct-verzorgenden en indirect 82,9 procent en 17,1 procent is (dit zijn cijfers over 1986 en 1987). De Nationale Kruisvereniging vindt dat deze verhouding gunstig afsteekt bij die van een groot aantal andere sectoren in de gezondheidszorg. Dit wordt verder niet gespecificeerd of met cijfermateriaal onderbouwd. De Nationale Raad schrijtt de relatief sterke stijging van niet-direct patiëntgebonden personeel toe aan "het feit dat de administratieve infrastructuur van het Kruiswerk, ten tijde van de invoering van de AWBZ-financiering in 1980, onvoldoende was toegerust om adequaat te kunnen inspelen op de verzwaring van administratieve regelgeving als gevolg van de gewijzigde financiering..." (Nationale Raad voor de Volksgezondheid, 1986, p.94).

Voor het Kruiswerk geldt, evenals voor de intramurale sector, de conclusie dat het beeld dat het Financieel Overzicht van de werkelijkheid pretendeert te bieden vollediger zou zijn wanneer deze kosten deel uitmaken van het hoofdstuk "kosten van beleid, administratie en beheer".

De (zij het "vervuilde") aanvullingen van de intramurale sector en het Kruiswerk op de kosten van beleid, administratie en beheer uit het Financieel Overzicht zijn weergegeven in tabel 5.8 .

Tabel 5.8 Aanvullingen op de kosten van beleid, administratie en beheer volgens het Financieel Overzicht (in miljoenen guldens)

\begin{tabular}{|c|c|c|c|c|c|c|c|c|c|}
\hline & 1980 & 1981 & 1982 & 1983 & 1984 & 1925 & 1986 & 1987 & 1988 \\
\hline $\begin{array}{l}\text { alg. pors. } \\
\text { intramuraal }\end{array}$ & 1.905 & 2.029 & 2.169 & 2.191 & 2.122 & 2.212 & 2.449 & 2.474 & 2.500 \\
\hline $\begin{array}{l}\text { dir. on staf } \\
\text { kruiswerk }\end{array}$ & 11 & 12 & 13 & 14 & 15 & 18 & 22 & 25 & 26 \\
\hline Totanal & 1.916 & 2.041 & 2.182 & 2.205 & 2.137 & 2.231 & 2.471 & 2.499 & 2.526 \\
\hline b.a.b. volgens F.O. & 1.152 & 1.248 & 1.392 & 1.559 & 1.639 & 1.699 & 1.860 & 1.826 & 1.863 \\
\hline $\begin{array}{l}\text { Totaal b.a.b. } \\
\text { incl. aanv. }\end{array}$ & 3.068 & 3.289 & 3.574 & 3.764 & 3.776 & 3.930 & 4.331 & 4.325 & 4.389 \\
\hline
\end{tabular}

b.a.b. = beleid, administratie on behoer

F.O. - Financleol Overzicht

Gebaseerd op: Tabellen 5.6 en 5.7

Het resultaat van deze inventarisatie is dat in het Financieel Overzicht de kosten van beleid, administratie en beheer bijna vijf procent uitmaken van de totale kosten in de zorgsector. Het percentage van de bestuurskosten, zoals hier berekend, bedraagt bijna twaalf procent (zie tabel 5.9). Overigens is geen recenter cijfermateriaal opgenomen omdat dit nog ontbreekt. Men moet zich echter wel realiseren dat deze twaalf procent een maximum weergeven, aangezien door vervuiling van de gegevens overschatting is opgetreden. Men zou kunnen zeggen dat de werkelijke bestuurskosten in de gezondheidszorg zeker geen vijf procent bedragen, maar ook niet helemaal twaalf. 
Tabel 5.9 Het percentage kosten van beleid, administratie en beheer en bestuurskosten van de totale kosten in de gezondheidszorg

\begin{tabular}{l|ccccccccc}
\hline & 1980 & 1981 & 1982 & 1983 & 1984 & 1985 & 1986 & 1987 & 1988 \\
\hline \% kosten van b.a.b. & 4,2 & 4,2 & 4,4 & 4,8 & 4,9 & 5,0 & 5,2 & 5,0 & 4,9 \\
\% bestuurskosten & 11,1 & 11,1 & 11,3 & 11,5 & 11,3 & 11,4 & 12,1 & 11,8 & 11,6 \\
\hline
\end{tabular}

Gebaseerd op: tabel 5.8

Wanneer de registratie van de bestuurskosten in de overige sectoren systematisch zou gebeuren zou het percentage van de bestuurskosten nog toenemen.

Concluderend kan worden gesteld dat het hoofdstuk "kosten van beleid, administratie en beheer" kan worden uitgebreid. Over zowel de sector "intramurale gezondheidszorg" als over het Kruiswerk is voldoende informatie beschikbaar. Uitbreiding is echter niet alleen aan te bevelen, omdat dit methodisch-technisch mogelijk is, maar cok omdat het een vollediger beeld biedt van de werkelijke omvang van de bestuurskosten in de gezondheidszorg.

\section{$\S$ 5.3.3 De bestuurskosten en de stelselwijziging}

De invoering van de "kleine stelselwijziging" had de beheerskosten van verzekeraars moeten beperken of op z'n minst gelijk houden. Diverse malen echter wordt in de Financiële Overzichten (1987-1988; 1988-1989) vermeld dat de beheerskosten bij de particuliere verzekeraars zijn gestegen als gevolg van de "kleine stelselwijziging". En dat terwijl het de bedoeling was dat de particuliere verzekeraars extra geld zouden krijgen voor het overnemen van voormalig vrijwillig ziekenfondsverzekerden. Dit extra bedrag zou worden ingehouden op de beheerskostenbudgetten van de ziekenfondsen, aangezien bij de ziekenfondsen een vereenvoudiging optreedt van de administratie door het opheffen van twee verzekeringsvormen. Kennelijk is de verwachte kostenbesparing uitgebleven.

De gevolgen van de "grote stelselwijziging" zijn niet duidelijk. De Wet op de Zorgverlening zou per 1 januari 1995 in haar geheel moeten zijn ingevoerd. De politieke tegenstand en praktische problemen bij verzekeraars hebben ervoor gezorgd dat de plannen nog niet zijn uitgevoerd. Afgezien hiervan kan men speculeren welke gevolgen de "grote stelselwijziging" zou hebben gehad op de hoogte van de bestuurskosten. De verwachting is dat de bestuurskosten zouden zijn gestegen, doordat:

- de verbindingskantoren die de Algemene Wet Bijzondere Ziektekosten uitvoeren, zijn opgeheven. De individuele verzekeraars nemen de taken van deze kantoren over. Doordat veel individuele verzekeraars deze taak overnemen veroorzaakt dit veel meer beheerskosten dan wanneer enkele instanties de uitvoering verzorgen. het natura-systeem waarbij de zorgverstrekkers rechtstreeks door de ziekenfondsen betaald werden, zou worden vervangen door het restitutie-systeem. Dit houdt in dat de patiënten eerst alle handelingen en medicamenten zelf dienen te betalen en vervolgens declareren bij de verzekeraars. Deze moeten de declaraties daarna weer vergoeden aan de verzekerden. Hoewel de consumptie van zorg wellicht zal dalen, zal deze constructie veel meer administratieve rompslomp en dus beheerskosten met zich brengen dan rechtstreekse vergoeding door verzekeraars aan de verstrekkers van zorg. 
- de contracteerplicht van de verzekeraars zou vervallen. Alle verzekeraars zouden met alle individuele zorgverstrekkers moeten onderhandelen over produktie en tarieven. Tot nu toe gold voor bijvoorbeeld huisartsen een contracteerplicht, zodat alle huisartsen automatisch gecontracteerd waren en onderhandelingen achterwege konden blijven. Door opheffing van de contracteerplicht zullen de bestuurskosten dus eveneens stijgen.

De Ziekenfondsraad heeft in haar rapport "Nader advies tweede fase stelselwijziging" (1991) geinventariseerd welke de mogelijke gevolgen zullen zijn van het wegvallen van de AWBZ-verbindingskantoren. Deze zijn:

- versnippering van de activiteiten over alle afzonderlijke uitvoeringsorganen;

- verveelvoudiging van contacten rond tariefonderhandelingen, produktie-afspraken, kwaliteitsbeoordeling en dergelijke;

- toenemende administratieve belasting en registratie bij instellingen en verzekeringsinstanties;

- toename van het betalingsverkeer;

- toename van de registratie door de crediteuren.

De Ziekenfondsraad schat dat na de invoering van de stelselwijziging de kosten voor de uitvoeringsorganen van de Algemene Wet Bijzondere Ziektekosten in 1991 met $f 120$ miljoen en in de volgende jaren met $f 250$ miljoen zullen stijgen (1991, p.21). Daar staat evenwel tegenover dat zich wellicht besparingen zullen voordoen bij het ministerie van Welzijn, Volksgezondheid en Cultuur, provincies, gemeenten en het Centraal Orgaan Tarieven Gezondheidszorg door de deregulering die het gevolg is van de beoogde stelselwijziging.

Ontwikkelingen in de Verenigde Staten bevestigen de veronderstelde kostenstijging. De United States General Accounting Office (1991) heeft deze veronderstelling met cijfermateriaal onderbouwd. Berekeningen hebben aangetoond dat in het geval van een uniform systeem waarbij de verzekeraar tevens de aan de instellingen uitkerende instantie is, de administratiekosten aanzienlijk lager zijn. Dit geldt zowel voor de "health care administration costs" bij verzekeraars als bij gezondheidszorginstellingen. Woolhandler en Himmelstein (1986; 1991) spreken in deze context over "administrative waste". Reinhardt (1991) heeft hiervoor de term "medical B-factor" bedacht. Deze factor geeft de verhouding weer tussen het aantal directe en het aantal indirecte (bureau-)werkers in de gezondheidszorg (zie verder paragraaf 5.3.4).

Overigens wordt hun visie niet algemeen onderschreven. Opponenten (Danzon, 1992; Thorpe, 1992) gaan in op de zorginhoudelijke gevolgen. Zij betogen dat een uniform financieringssysteem door de monopoliepositie van enkele verzekeraars negatieve bijwerkingen zal hebben. Zo verwachten zij dat de wachttijden voor cliënten zullen toenemen, waardoor deze mensen langer zullen verzuimen op hun werk en hun produktiviteit afneemt; dat de gezondheidstoestand van patiënten zal verslechteren, doordat de wachtlijsten langer zullen zijn en het dus ook langer duurt voordat men wordt geholpen; dat de geboden zorg slechter zal zijn, wanneer artsen in dienstverband gaan werken. Danzon en Thorpe geven geen commentaar op de hoogte van de bestuurskosten, zoals deze in voornoemde publicaties worden geschat.

Of dit alles in Nederland ook staat te gebeuren, is nog maar de vraag. Vooralsnog is de stelselwijziging in de ijskast gezet. 
artsen in dienstverband gaan werken. Danzon en Thorpe geven geen commentaar op de hoogte van de bestuurskosten, zoals deze in voornoemde publicaties worden geschat.

Of dit alles in Nederland ook staat te gebeuren, is nog maar de vraag. Vooralsnog is de stelselwijziging in de ijskast gezet.

\section{§ 5.3.4 Aanvullingen op het hoofdstuk "kosten van beleid, administratie en beheer" in aantallen formatieplaatsen}

De omvang van een bepaalde sector kan behalve door middel van kosten ook met behulp van het aantal formatieplaatsen tot uitdrukking worden gebracht. Het Financieel Overzicht geeft het aantal bezette arbeidsplaatsen in de bestuurlijke sector weer (zie tabel 5.3). Welke plaatsen hiertoe precies worden gerekend, is onduidelijk.

Ook op dit overzicht zijn aanvullingen of verduidelijkingen mogelijk. Een overzicht hiervan geeft tabel 5.10. Bij de intramurale gezondheidszorg, de ziekenfondsen en de kruisverenigingen is uitgegaan van de indirecte medewerkers (zie paragraaf 5.3.2.1). De medewerkers van de overige instanties, zoals de Ziekenfondsraad, de Nationale Raad, worden allemaal als indirect beschouwd. Zij hebben immers geen van allen rechtstreeks te maken met gebruikers van de gezondheidszorg.

Overigens geldt dezelfde kanttekening als hiervoor (in paragraaf 5.3.2). In het weergegeven aantal arbeidsplaatsen in de bestuurlijke sector van de intramurale gezondheidszorg is eveneens sprake van vervuiling. Ook hier geeft de aanvulling op de bestaande getallen een maximum weer. De arbeidsplaatsen die nodig zijn voor beheersmatige activiteiten zijn immers meegerekend.Tabel 5.10 laat een stijging zien van het aantal arbeidsplaatsen in de bestuurlijke sector van de gezondheidszorg.

Vergelijking met tabel 5.3 leert dat ook hier de aantallen uit het Financieel Overzicht onvolledig zijn. Volgens tabel 5.3 is het aantal bezette arbeidsplaatsen in de bestuurlijke sector aan het eind van de jaren tachtig 15 duizend. Hierbij is onduidelijk welke werkers tot deze categorie worden gerekend. Betreft dit bijvoorbeeld de medewerkers bij ziekenfondsen, particuliere ziektekostenverzekeraars en het directoraat-Generaal van de Volksgezondheid of worden hiermee andere categorieën bedoeld? Volgens tabel 5.10 wordt het, zoals gezegd vervuilde, aantal bijna 80 duizend. 
Tabel 5.10 Aanvullingen op het arbeidsplaatsenoverzicht voor de bestuurlijke sector van het Financieel Overzicht (in aantallen formatieplaatsen*)

\begin{tabular}{|c|c|c|c|c|c|c|c|c|c|}
\hline & 1980 & 1981 & 1982 & 1983 & 1984 & 1985 & 1986 & 1987 & 1988 \\
\hline intramurasal & 68.830 & 69.832 & 70.429 & 69.958 & 69.310 & 69.532 & 69.863 & 70.164 & 69.656 \\
\hline ziekenfondsen & p.m. & 7.077 & 7.487 & 7.817 & 8.357 & 8.842 & 8.346 & 0.398 & 8.160 \\
\hline kruisverenigingen & 199 & 208 & 220 & 2299 & 249 & 305 & 358 & 402 & 413 \\
\hline ziekenfondsraad & 299 & 318 & 326 & 338 & 346 & 346 & 349 & 339 & 322 \\
\hline nationale raad & o.m. & p. m. & p.m. & 42 & 52 & 54 & 66 & 70 & p.m. \\
\hline gezondheldsrasd & o.m. & p.m. & p.m. & 39 & 41 & 44 & 36 & 37 & 34 \\
\hline $\begin{array}{l}\text { coll. v. ziekenh. } \\
\text { voor. }\end{array}$ & 60 & 63 & p.m. & 76 & 78 & 81 & 83 & 90 & 90 \\
\hline $\mathrm{COZ} / \mathrm{COTG}$ & 38 & 40 & 50 & 55 & 62 & 69 & 74 & 74 & 70 \\
\hline VNZ & 150 & 173 & 198 & 218 & 222 & 200 & 195 & 174 & 151 \\
\hline NZR & 134 & p.m. & p.m. & 147 & 150 & 155 & 164 & 157 & 159 \\
\hline NZI & p.m. & p.m. & p.m. & 112 & 123 & 121 & 125 & 127 & 150 \\
\hline totaal & 69.710 & 77.711 & 78.710 & 79.031 & 78.990 & 79.749 & 79.659 & 80.032 & 79.205 \\
\hline
\end{tabular}

- = deekijdfuncties zijn omgerekend en afgerond

p.m. = gegevens ontbreken

Bronnen: jaarverslagen van Ziekenfondsraad, Nationale Kruisverenlging. Nationale Raad voor de Volksgezondheld, Gezondheidsraad, College voor Ziekenhulsvoorzienlngen, Centraal Orgaan Zlekenhulstarieven / Centraal

Orgaan Tarieven Gezondheidszorg, Vereniging van Nederlandse Ziekentondsen. Nationale Zlekenhuisraed Nationaal Ziekenhuisinstituut

Ook bij het directoraat-generaal van de Volksgezondheid van het ministerie is de personeelssterkte in de loop der jaren aanzienlijk toegenomen. Inzicht hierin biedt figuur 5.2. 
Figuur 5.2 Ontwikkeling van het aantal arbeidsplaatsen in de gezondheidszorg 1978-1984 $(1978=100)$

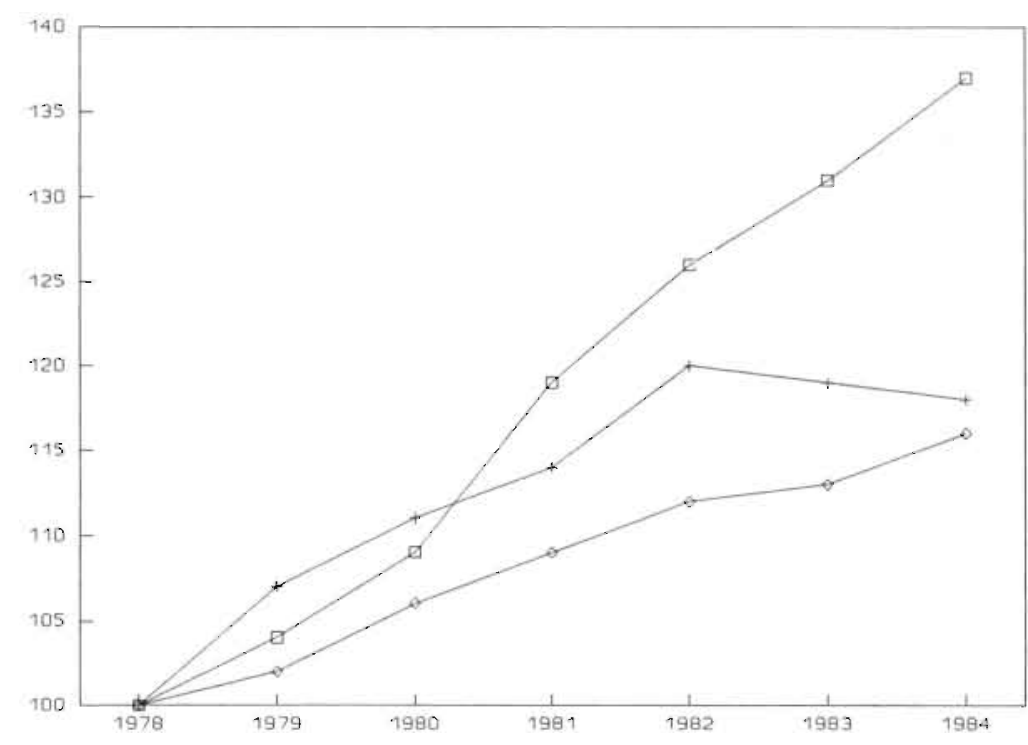

$\square-\square=$ arbeidsplaatsen beleid, administratie en beheer

$+--+=$ werkelijke personeelssterkte bij het directoraat-generaal van de Volksgezondheid (inclusief inspecties) van het ministerie van WVC casu quo VoMil

$\diamond-\diamond \quad=$ arbeidsplaatsten gezondheidszorg

Bron: J. Hofland en N.C.M. van Niekerk

Bedrijvige overheid; naar een betere informatievoorziening van de overheid Instituut voor Onderzoek naar Overheidsuitgaven, 1985, p.39

Interessant is voorts berekening van de "medical B-factor" volgens Reinhardt (1991). Deze berekening levert het volgende op. De "medical B-factor" in de gezondheidszorg is ongeveer 0,3. Dit houdt in dat op drie directe werkers éen indirecte werker in de gezondheidszorg is aangesteld.

Uit het voorgaande blijkt dat ook het aantal arbeidsplaatsen in de bestuurlijke sector gedurende de afgelopen jaren als mar is blijven stijgen. Oorzaak hiervan zou kunnen zijn het toegenomen aantal maatregelen en regelingen waar zo ongeveer iedere organisatie in de gezondheidszorg mee te maken heeft. Daarbij komt dat de complexiteit van de sector is toegenomen. Anderzijds zou men ook kunnen stellen dat pogingen, althans op papier, om de gezondheidszorg te ontbureaucratiseren, voorals nog weinig resultaat hebben geboekt. 


\section{\$5.4 Evaluatie van de bepaling van de bestuurskosten als aanvulling op het}

Financieel Overzicht

In deze paragraaf komen de methodologische voorwaarden, zoals deze in hoofdstuk 4 zijn gesteld, aan de orde.

De validiteit betreft de vraag of men meet wat men wil meten. In het geval van de kosten van beleid, administratie en beheer in het Financieel Overzicht is daar geen sprake van. Deze zjjn willekeurig afgebakend, want de bestuurskosten bij bijvoorbeeld instellingen ontbreken. Daarom is in deze studie naar aanvullingen op de kosten van beleid, administratie en beheer gezocht. Dit betreft de verborgen beleidskosten die zich bij instellingen voordoen. Deze poging is echter slechts gedeeltelijk gelukt aangezien de verborgen beleidskosten bij instellingen deels het gevolg zijn van het voeren van intern beleid en beheer. Hierdoor hanteert men de brede benadering van bestuurskosten. De kosten die directies en stafafdelingen voor het interne beheer maken zouden voor een deel ook zonder overheidsbesturing worden gemaakt en zouden dus eigenlijk buiten beschouwing moeten blijven. Volgens de in deze studie gehanteerde enge benadering van bestuurskosten.

De betrouwbaarheid betreft het cijfermateriaal. Met name op het cijfermateriaal dat in de eerste Financiële Overzichten is gebruikt, is het nodige aan te merken. Inmiddels lijkt hierin echter verbetering te zijn gekomen. Bovendien veranderen in het Financieel Overzicht regelmatig de hoofdstukindeling en de sectorgrootte en worden veel verschillende bronnen gebruikt. Dit bemoeilijkt de vergelijkbaarheid en veroorzaakt wellicht dubbeltellingen. De betrouwbaarheid van de eigen meting is zoveel mogelijk benaderd doordat een systematische beschrijving is geboden van de herkomst van het gepresenteerde cijfermateriaal en van de meting zelf.

Het probleem van de generaliseerbaarheid is hier niet aan de orde. Het is niet de bedoeling en ook niet mogelijk de resultaten te generaliseren.

\section{$\S 5.5$ Samenvatting en conclusies}

In dit hoofdstuk zijn aanvullingen gezocht op de kostenpost "beleid, administratie en beheer" van het Financieel Overzicht om zo een vollediger beeld te geven van de bestuurskosten in de gezondheidszorg.

Het Financieel Overzicht is een bijlage bij de rijksbegroting, die gegevens bevat omtrent de kosten en het volume van de zorgsector. Het Financieel Overzicht is zodanig ingedeeld dat ieder hoofdstuk een soort voorziening dekt.

Het doel van het Financieel Overzicht is enerzijds om de stand van zaken weer te geven betreffende de kosten en de produktie en anderzijds om de grenzen aan de geven voor de kosten van de komende jaren.

Het bereik van het Financieel Overzicht is toegenomen van alleen de gezondheidszorgsector tot de gezondheidszorg met daaraan toegevoegd de maatschappelijke dienstverlening. Tegenwoordig spreekt men over de zorgsector. De naamgeving van het Financieel Overzicht is steeds navenant geweest.

Een wettelijke status heeft het Financieel Overzicht nooit gekregen. Middels de ontwerp-Wet Gezondheidszorg en Maatschappelijke dienstverlening was dit wel de bedoeling, maar aangezien de regering het ontwerp weer heeft ingetrokken, is de wettelijke status voor het Financieel Overzicht ook uitgebleven. Daarmee is de status van het Financieel Overzicht niet meer en niet minder dan die van een kwantitatieve vertaling van het in de Memorie van Toelichting op de Rijksbegroting aangegeven beleid voor de gezondheidszorg. 
Het Financiee| Overzicht komt tot stand door middel van een vaste jaarlijkse cyclus. Voorbereiding vindt plaats door middel van adviezen van diverse adviesorganen. Vervolgens werken rekengroepen van het ministerie ieder éen hoofdstuk uit. Het Financieel Overzicht wordt bij de begroting aan de Tweede Kamer aangeboden en daar tenslotte behandeld.

Het Financieel Overzicht bevat beleidsvoornemens en prioriteitenstellingen. Verder worden de algemene ontwikkelingen van de gehele sector geschetst. Daarna wordt in ieder hoofdstuk apart aandacht geschonken aan een soort voorzieningen.

Het hoofdstuk "kosten van beleid, administratie en beheer" geeft inzicht in de kosten van de "papieren sector" van de gezondheidszorg. Hiertoe behoren de kosten van de overheden, verzekeraars en de adviesorganen. De posten in het hoofdstuk zijn: beheerskosten ziekenfondsen, kosten Ziekenfondsraad en secretariaat, beheerskosten uitvoerende organen Algemene Wet Bijzondere Ziektekosten, kosten premie-inning Algemene Wet Bijzondere Ziektekosten en Ziekenfondswet, College voor Ziekenhuisvoorzieningen, Centraal Orgaan Tarieven Gezondheidszorg, beheerskosten overheid, beheerskosten particulier.

Aanvankelijk bestond geen aparte rekengroep, die het hoofdstuk "kosten van beleid, administratie en beheer" tot stand bracht. Onlangs is echter wel een aparte rekengroep in het leven geroepen. Deze bestaat uit vertegenwoordigers van het Centraal Bureau voor de Statistiek, de Ziekenfondsraad, het Kontaktorgaan Landelijke Organisaties van Ziektekostenverzekeraars, de Kontaktkommissie Publiekrechtelijke Ziektekostenregelingen voor ambtenaren, de Vereniging van Nederlandse Gemeenten, de Nationale Raad voor de Volksgezondheid, het Centraal Planbureau, het Rijksinstituut voor Volksgezondheid en Milieuhygiëne, het Centraal Orgaan Tarieven Gezondheidszorg, het Ministerie van Welzijn, Volksgezondheid en Cultuur en van Financiën. De rekengroep beoordeeit het cijfermateriaal, stemt het op elkaar af en verklaart de cijfermatige ontwikkelingen.

Het hoofdstuk "kosten van beleid, administratie en beheer" geeft slechts een indruk van de bestuurskosten. De bestuurskosten die instellingen en individuele werkers in de gezondheidszorg maken, ontbreken.

Aan de hand van de statistieken van het Centraal Bureau voor de Statistiek en het Nationaal Ziekenhuisinstituut is het mogelijk de bestuurskosten voor de instellingen te benaderen. De bestuurskosten van het Kruiswerk zijn af te leiden uit gegevens van het Centraal Bureau voor de Statistiek.

De kosten van beleid, administratie en beheer nemen momenteel volgens gegevens uit het Financieel Overzicht bijna vijf procent van de totale kosten van de zorgsector voor hun rekening. De bestuurskosten in brede zin nemen maximaal bijna twaalf procent van de totale kosten in de gezondheidszorg in beslag. Aangezien deze laatste berekening van een maximum uitgaat, zal het werkelijke aantal wel iets minder zijn dan twaalf procent

Aanvullingen op het aantal formatieplaatsen in de bestuurlijke sector levert een aantal op van bijna 80 duizend in plaats van 15 duizend uit het Financieel Overzicht. De zogeheten "medical B-factor" bedraagt in de Nederlandse gezondheidszorg 0,3. Hetgeen betekent dat per drie directe medewerkers één indirecte werker is aangesteld in de gezondheidszorg.

Evaluatie van de bepaling van de bestuurskosten betreffen met name de validiteit. Noodgedwongen is immers bij het verzamelen van aanvullingen "vervuiling" van de bestuurskosten opgetreden. De brede benadering is onbedoeld gehanteerd, omdat een bepaald gedeelte van de kosten van bijvoorbeeld directies van instellingen ook zonder overheidsregelingen zouden zijn gemaakt.

De betrouwbaarheid is een probleem gezien de verschillende bronnen waaruit het cijfermateriaal is geput. Bovendien is in het Financieel Overzicht veelvuldig de hoofdstukindeling en de sectorgrootte veranderd waardoor vergelijking door de jaren heen vrijwel onmogelijk wordt. 
Generaliseerbaarheid is voor de bepaling van de bestuurskosten in het Financieel Overzicht niet aan de orde. 


\section{Hoofdstuk 6}

\section{BESTUURSKOSTEN IN DOORLOOPTIJD}

\section{§6.1 Inleiding}

In het vorige hoofdstuk is de ontwikkeling van de bestuurskosten in de gezondheidszorg geanalyseerd. Hierbij werd vooral gebruik gemaakt van gegevens uit de Financiële Overzichten. Deze gegevens betroffen het totale niveau van de bestuurskosten bij instanties, zoals overheden, verzekeraars, adviesorganen.

In dit hoofdstuk zal de bepaling worden toegespitst op de bestuurskosten die het gevolg zijn van de uitvoering van een bepaalde beleidsmaatregel. Zoals in hoofdstuk 4 is uiteengezet, kunnen deze kosten op verschillende manieren worden gemeten. Eén van deze manieren betreft het meten van de doorlooptijd van uitvoeringsprocessen. Onder de doorlooptijd wordt daarbij verstaan de tijd die verstrijkt tussen het begin en het einde van een procedure. Een belangrijk pluspunt van deze meting is dat het iets zegt over het tempo van de besluitvorming. Dit is een belangrijk politiek gegeven.

De meting van de bestuurskosten aan de hand van de doorlooptijd is niet nieuw. Zo constateerde Baakman in zijn studie naar de besluitvorming over de ziekenhuisbouw, dat het aantal besluitvormingsdagen voor de bouw van een nieuw ziekenhuis in Zutphen tussen 1959 en 1972 ongeveer 4.688 dagen bedroeg en voor de bouw van een nieuw ziekenhuis in Nijmegen tussen 1970 en 1985 zelfs 11.505 dagen (Baakman, 1990). Hierbij moet overigens wel worden opgemerkt, dat de bestuurlijke voorbereiding van de nieuwbouw zowel in Zutphen als in Nijmegen werd beïnvloed door een fusie van de betrokken ziekenhuizen. Deze fusie vergde uiteraard ook veel tijd. 
De Algemene Rekenkamer (1989-1990) heeft de doorlooptijd bepaald van de verlening van bouwvergunningen voor ziekenhuisvoorzieningen. Zij kwam tot de conclusie dat de maximale doorlooptijd volgens de wettekst zes jaar bedraagt. De werkelijke doorlooptijd varieerde van vier tot meer dan tien jaar.

Eerder zijn Krol en Passchier in hun evaluatie van de ziekenhuisplanning tot de slotsom gekomen, dat de totstandkoming van de provinciale ziekenhuisplanning zeer moeizaam verliep en in ieder geval veel meer tijd zou kosten dan de periodes die in de wettekst worden genoemd. Zo zijn de onderzoekers uitgekomen op gemiddeld 52 maanden, terwijl de wettelijke termijn 21 maanden bedroeg (Krol en Passchier, 1986).

In dit hoofdstuk zal de doorlooptijd van de planningsbesluiten en de besluitvorming over de vergunningen in het kader van de zogeheten artikel 18 voorzieningen ex Wet Voorzieningen Gezondheidszorg worden gemeten. De meting van de doorlooptijden van de planningsbesluiten geschiedt daarbij op landelijk niveau. De meting van de doorlooptijden van de besluitvorming over de vergunningen betreft alleen de aanvragen die zijn ingediend door de ziekenhuizen in de provincie Limburg.

De opbouw van dit hoofdstuk is verder als volgt. Paragraaf 6.2 gaat in op de achtergrond van artikel 18. Paragraaf 6.3 is gewijd aan de meting van bestuurskosten aan de hand van de doorlooptijden. In paragraaf 6.4 volgt een nabeschouwing over de meting van bestuurskosten aan de hand van de doorlooptijden aan de hand van het validiteits-, betrouwbaarheids- en toepasbaarheidscriterium. Het hoofdstuk wordt tenslotte afgesloten met een beknopte samenvatting van de onderzoeksresultaten.

\section{$\$ 6.2$ Achtergrond: artikel 18 Wet Zekenhuisvoorzieningen}

Artikel 18 van de Wet Ziekenhuisvoorzieningen stelt de staatssecretaris in staat zowel het personeel als de apparatuur ten behoeve van superspecialismen aan een vergunningenstelsel te binden. Krachtens de wettekst is het verboden om zonder vergunning verrichtingen uit te voeren of topklinische apparatuur aan te schaffen. De staatssecretaris bepaalt de behoefte aan superspecialistische voorzieningen en de manier waarop in die behoefte zal worden voorzien. De doelstellingen van artikel 18 zijn: een goede spreiding van superspecialistische voorzieningen, optimale benutting van deze kostbare voorzieningen en handhaving van de kwaliteit van de topklinische zorg (Wet Ziekenhuisvoorzieningen, 1986).

De werkingssfeer van artikel 18 omvat "diagnostische en therapeutische verrichtingen, die specifieke deskundigheid en/of belangrijke investeringen in apparatuur en eventuele andere middelen, waaronder personeel vergen" (Wet Ziekenhuisvoorzieningen, 1986, p.96). Dit houdt in dat uitbreiding van bestaande topklinische voorzieningen en vestiging van nieuwe voorzieningen verboden zijn, tenzij men in het bezit is van een vergunning. Aanvankelijk was artikel 18 niet van toepassing op academische en militaire ziekenhuizen. Met ingang van 1 januari 1988 is dit wel het geval (1988-1989).

Artikel 18 heeft diverse raakvlakken met andere regelingen. In de eerste plaats bestaat een verband met de Wet Tarieven Gezondheidszorg. De hoogte van een instellingsbudget krachtens de Wet Tarieven Gezondheidszorg wordt mede bepaald door de aanwezigheid van artikel 18-voorzieningen. Deze artikel 18- 
voorzieningen verhogen het budget van een instelling (Topklinische zorg 19911994, 1990-1991). Een onbedoelde bijwerking van deze koppeling is een stroom van vergunningaanvragen door instellingen met het oog op budgetverhoging (College voor Ziekenhuisvoorzieningen, 1987).

Daarnaast kent artikel 17 van de Wet Tarieven Gezondheidszorg een soortgelijke werking als artikel 18 van de Wet Ziekenhuisvoorzieningen. Het eerstgenoemde artikel beoogt immers eveneens het aangaan van financiele verplichtingen door gezondheidszorginstellingen te beheersen (Wet Tarieven Gezondheidszorg, 1986). Tot nu toe is alleen in 1984 de kernspintomograaf, de zogeheten Nuclear Magnetic Resonance-apparatuur, onder de werking van artikel 17 van de Wet Tarieven Gezondheidszorg gebracht. De reden warom artikel 17 van de Wet Tarieven Gezondheidszorg en niet artikel 18 van de Wet Ziekenhuisvoorzieningen is toegepast, is dat op deze wijze de tijdrovende adviesprocedures konden worden ontweken (Wet Tarieven Gezondheidszorg, 1986). Overigens kan artikel 17 alleen de financiering van apparatuur en niet de aanschaf tegenhouden. Planning van de spreiding van voorzieningen is onmogelijk op grond van artikel 17 van de Wet Tarieven Gezondheidszorg (College voor Ziekenhuisvoorzieningen, 1985).

De relatie tussen artikel 18 enerzijds en de financiering van gezondheidszorgvoorzieningen anderzijds is als volgt. Aanspraken van ziekenfondsverzekerden liggen vast in het Verstrekkingenbesluit Ziekenfondsverzekering. Dit besluit geeft aan dat verzekerden recht hebben op vergoeding van zorg die als gebruikelijk wordt beschouwd. Aangezien deze omschrijving geen scherpe afbakening biedt voor de zorg die gefinancierd wordt, is het onduidelijk of nieuwe technieken tot de "gebruikelijke zorg" behoren. Het Besluit tijdelijke regeling in vitro fertilisatie (Wet Ziekenhuisvoorzieningen, 1986) geeft in ieder geval aan dat wanneer een instelling een vergunning voor de toepassing van in vitro fertilisatie bezit, dit nog geen garantie betekent voor financiering volgens de Ziekenfondswet of de Algemene Wet Bijzondere Ziektekosten.

Hoewel in de wettekst en in de later uitgebrachte Besluiten niet expliciet melding wordt gemaakt van een relatie tussen artikel 18 en het Financieel Overzicht, bestaat deze wel. In het Financieel Overzicht wordt in feite het financiële kader aangegeven waarbinnen de groei van de uitgaven ten behoeve van artikel 18-voorzieningen dient te blijven. Overigens is hiervan pas sedert enkele jaren expliciet sprake. In het Financieel Overzicht van 1984 werd voor het eerst melding gemaakt van een financieel kader voor superspecialistische voorzieningen. Voor de jaren 1984 tot 1986 mocht de groei $f 30$ miljoen bedragen. In het Financieel Overzicht van 1988 werd voor 1987 een groei van $f 15$ miljoen toegestaan en voor 1988 van $f 40$ miljoen. In het Financieel Overzicht van 1989 is voor 1989 een groei van $f 25$ miljoen en in het Overzicht van 1990 voor 1990 van $f 21$ miljoen uitgetrokken. Kort weergegeven levert dit tabel 6.1 op.

Tabel 6.1 Toegestane groei van de uitgaven voor artikel 18-voorzieningen (in miljoenen guldens)

\begin{tabular}{lllllllll}
\hline & 1984 & 1985 & 1986 & 1987 & 1988 & 1989 & 1990 & 1991 \\
\hline $\begin{array}{l}\text { toegestane groei } \\
\text { topklinisch budget }\end{array}$ & 30 & 30 & 30 & 15 & 40 & 25 & 21 & 23 \\
\hline
\end{tabular}

Bron: Financiële Overzichten 1984 t/m 1992

Een expliciet verband tussen de planningsbesluiten en het toegestane budget voor topklinische zorg wordt in de Financiële Overzichten echter niet gelegd. Inkrinmping van het aantal planningsbesluiten leidt niet tot verlaging van de post 
"topklinische zorg" in het Financieel Overzicht. Zo is in november 1988 een tweetal voorzieningen buiten artikel 18 geplaatst. Het budget voor 1988 was met $f 40$ miljoen echter groter dan ooit.

Tenslotte bestaat een relatie tussen artikel 18 en de zogeheten ontwikkelingsgeneeskunde. Aanvankelijk betekende ontwikkelingsgeneeskunde nieuw ontwikkelde diagnostiek en behandeling. Tegenwoordig houdt ontwikkelingsgeneeskunde in de beoordeling van bepaalde medische technologieën aan de hand van onderzoek en patiëntenzorg. In de wettekst wordt ontwikkelingsgeneeskunde omschreven als "de op wetenschappelijk inzicht gebaseerde ontwikkeling en evaluatie van methoden en technieken binnen de praktijkomstandigheden van een ziekenhuisvoorziening, waarvan de uiteindelijke toepassing ingrijpende kwalitatieve, maatschappelijke, ethische, juridische, financiële of organisatorische gevolgen in de gezondheidszorg kan hebben" (Wet van 4 oktober 1990, houdende wijziging van de Wet op het Wetenschappelijk onderwijs en de Wet Ziekenhuisvoorzieningen met betrekking tot de academische ziekenhuizen, 1990, p.13). Het betreft nieuwe zorgsoorten waarvoor al dan niet kostbare apparatuur en bouwkundige voorzieningen nodig zijn. Hierbij wordt onder meer bekeken of nieuwe behandelvormen in het verstrekkingenpakket moeten worden opgenomen en verouderde eventueel vervangen. Deze nieuwe behandelvormen worden gedurende twee jaar gefinancierd uit een speciaal fonds. Daarna wordt bezien of andere financiering zinvol of wenselijk is. De staatssecretaris kan gelijktijdig met de start van een ontwikkelingsgeneeskundig project een tijdelijke regeling ex artikel 18 in werking stellen (Mandena, Den Otter, Van Peperzeel, Schweitzer, 1990).

In schema 6.1 worden de raakvlakken van artikel 18 met andere regelingen weergegeven.

Schema 6.1 De raakvlakken van artikel 18 Wet Ziekenhuisvoorzieningen met andere regelingen

\begin{tabular}{|c|c|}
\hline Regeling: & Raakvlak: \\
\hline $\begin{array}{l}\text { budgettering ex Wet Ta- } \\
\text { rieven Gezondheidszorg }\end{array}$ & $\begin{array}{l}\text { artikel } 18 \text { beinvloedt de hoogte van het } \\
\text { instellingsbudget }\end{array}$ \\
\hline $\begin{array}{l}\text { artikel } 17 \text { Wet Tarieven } \\
\text { Gezondheidszorg }\end{array}$ & $\begin{array}{l}\text { heeft dezelfde werking als artikel 18; geldt uitslui- } \\
\text { tend voor de financiering }\end{array}$ \\
\hline financiering & $\begin{array}{l}\text { aanspraken van verzekerden op artikel 18- } \\
\text { voorzieningen liggen in feite vast in het } \\
\text { Verstrekkingenbesluit Ziekenfondswet }\end{array}$ \\
\hline Financieel Overzicht & $\begin{array}{l}\text { bevat een financieel kader voor artikel } 18 \text { - } \\
\text { voorzieningen }\end{array}$ \\
\hline ontwikkelingsgeneeskunde & $\begin{array}{l}\text { nieuwe, dure zorgsoorten worden eventueel tijde- } \\
\text { lijk onder artikel } 18 \text { gebracht }\end{array}$ \\
\hline
\end{tabular}

\section{§6.2.2 De artikel 18-voorzieningen}

Op basis van de dan nog ongewijzigde Wet Ziekenhuisvoorzieningen wordt in 1974 het "Besluit bijzondere ziekenhuisvoorzieningen" afgekondigd. Dit Besluit is van toepassing op een tweetal voorzieningen, te weten chronisch intermitterende haemodialyse en niertransplantatie. 
In het Besluit van 11 december 1978 wordt het Besluit van 1974 gewijzigd en wordt de megavolt-therapie onder de werking van antikel 18 gebracht.

Als gevolg van wijzigingen in de Wet Ziekenhuisvoorzieningen in 1978 (de Wet tot wijziging van de Wet Ziekenhuisvoorzieningen treedt op 1 september 1979 in werking) is het noodzakelijk dat ook het "Besluit bijzondere ziekenhuisvoorzieningen" wordt vervangen. Dit geschiedt in 1983 door middel van bekendmaking van het "Besluit bijzondere functies Wet ziekenhuisvoorzieningen". Van deze gelegenheid wordt gebruik gemaakt om de werkingssfeer van artikel 18 aanzienlijk uit te breiden. De invloed van de overheid met als doel beheersing van de kosten wordt erdoor vergroot. Vanaf dat moment is voor het uitvoeren van de volgende functies (of de aanschaf van apparatuur ten behoeve van deze uitvoering) een vergunning vereist:

\section{- diahyse:}

kunstmatige bloedzuivering ter vervanging van de nierfunctie zowel met behulp van een dialyse-apparaat als bloedzuivering via het buikvlies. Dit betekent een verruiming van de eerdergenoemde functie "chronisch intermitterende haemodialyse". Chronisch intermitterende haemodialyse vindt immers uitsluitend plaats buiten het lichaam, terwijl de zogeheten peritoneale dialyse plaatsvindt via spoelvloeistof in de buikholte (Planningsbesluit dialyse, 1987);

\section{- niertransplantatie:}

vervanging van één of beide nieren (Planningsbesluit niertransplantatie, 1986);

\section{- radiotherapie:}

behandeling van kankerpatiënten door middel van ioniserende straling. Dit betekent een verruiming van de functie "megavolt-therapie". Megavoltherapie heeft immers alleen betrekking op uitwendige bestraling, terwijl bij de zogeheten branchytherapie een ingekapselde radio-actieve bron in het lichaam wordt gebracht (Planningsbesluit radiotherapie, 1987);

\section{- neurochirurgie:}

chirurgische behandeling van het zenuwstelsel en van omringende lichaamsdelen, zoals hersenen en ruggemerg (Planningsbesluit neurochirurgie, 1987);

\section{- hartchirurgie:}

de chirurgische behandeling van aandoeningen aan het hart en de kransslagaderen, het pericard (hartzakje) en de uit het hart ontspringende of daarin uitmondende grote vaten. Voorbeelden van ingrepen zijn bypass-operaties of operaties wegens klepgebreken (Planningsbesluit hartchirurgie, 1989);

\section{- nucleaire geneeskunde:}

diagnostische en therapeutische handelingen met gebruikmaking van radio-actieve stoffen (concept-Planningsbesluit, 1985; dit voorlopig besluit vervalt in 1988);

- postnataal chromosoomonderzoek en prenatale diagnostiek:

onderzoek voor of na de geboorte naar aangeboren en/of erfelijke afwijkingen (Planningsbesluit postnataal chromosoomonderzoek en prenatale diagnostiek, 1987);

\section{- hartcatheterisatie:}

cardiodiagnostische onderzoeken door middel van contrastvloeistof en cardiotherapeutische ingrepen, bijvoorbeeld dotteren, met behulp van (hart)catheters 
- computertomografie:

diagnostiek die een combinatie vormt van computers en röntgenapparatuur. Door middel van een smalle bundel röntgenstralen die in een halve cirkel om het te onderzoeken lichaamsdeel draait en met behulp van een computer twee-dimensionale beelden oplevert (Planningsbesluit Computertomografie, 1986; besluit vervalt in 1988 ;

\section{- intensieve zorg voor zieke pasgeborenen:}

het verlenen van gespecialiseerde medische en verpleegkundige zorg in couveuses aan zieke pasgeborenen bij wie vitale functies, zoals de temperatuurregulatie of de immuniteit, op een accuut levensbedreigende manier gestoord danwel labiel zijn (Planningsbesluit intensieve zorg voor zieke pasgeborenen, 1987).

In 1985 wordt ingevolge het "Besluit tijdelijke regeling in vitro fertilisatie" bepaald, dat in de toekomst ook in vitro fertilisatie (buiten-lichamelijke bevruchting) onder het artikel 18-regime zal vallen. Het betreft een ijdelijk besluit, omdat de algemene maatregel van bestuur en het Planningsbesluit nog in voorbereiding zijn. De staatssecretaris wil hiermee versnippering en een ongebreidelde groei van het aantal plaatsen waar in vitro fertilisatie wordt aangeboden, voorkomen. Deze regeling geldt voor een periode van twee jaar en wordt in 1987 met één jaar verlengd.

Bij Besluit van 11 augustus 1988 wordt het voorlopige besluit definitief. Dit houdt in dat het Besluit bijzondere functies Wet Ziekenhuisvoorzieningen wordt uitgebreid met de functie "het buiten het lichaam tot stand brengen van menselijke embryo's als onderdeel van een in vitro fertilisatiebehandeling".

Tevens neemt de staatssecretaris bij die gelegenheid een aantal andere maatregelen. Zo is per 17 februari 1989 niet langer een vergunning voor "kleine aanschaffingen" en voor vervangingsaanschaffingen noodzakelijk. Tot "kleine aanschaffingen" behoren aanschaffingen van apparatuur met een afzonderlijke aanschafwaarde van minder dan $f 600.000,-$. Dat houdt bijvoorbeeld de volgende aanschaffingen in: onderdelen van apparatuur, hulp- of reserve-apparatuur en apparatuur die behalve voor de desbetreffende artikel 18-functie ook voor andere functies kan worden gebruikt. Vervangingsaanschaffingen die verder geen capaciteitsuitbreiding inhouden, kunnen eveneens zonder (nieuwe) vergunning worden gedaan. Ditzelfde geldt voor aanschaffingen uit kwalitatieve overwegingen, die geen capaciteitsuitbreiding met zich brengen. Voor al deze gevallen waarin voorheen wel een vergunning was vereist, geldt dat de vergunningeis "geen toegevoegde waarde meer heeft die opweegt tegen de administratieve inspanningen bij overheid, adviesorganen èn de ziekenhuizen", aldus een brief namens de staatssecretaris aan de Nationale Ziekenhuisraad (aug. 1988).

Daarnaast is een tweetal functies uit de werkingssfeer van artikel 18 verwijderd. Het gaat hierbij om computertomografie en nucleaire geneeskunde. De overwegingen hierbij waren de volgende. Computertomografie is inmiddels een routinematig toegepaste vorm van diagnostiek geworden, waarvan de doelmatigheid en de kosteneffectiviteit voldoende zijn aangetoond. Verder is de aanschafprijs per Computer Tomograaf inmiddels substantieel aan het dalen (1988). Voor nucleaire geneeskunde zijn de investeringen in apparatuur niet groter dan de investeringen voor moderne röntgenapparatuur die niet onder artikel 18 valt. Daarnaast zijn veelal ingrijpende bouwkundige aanpassingen noodzakelijk. Beheersing via de planningsen bouwartikelen van de Wet Ziekenhuisvoorzieningen blijt dan toch mogelijk. De 
kwaliteit wordt ook al gewaarborgd door middel van de Kernenergiewet. Bovendien geldt ook hier dat de kosten niet langer buitensporig hoog zijn (1988) (zie hierover verder paragraaf 6.3.1 omtrent de verwikkelingen rond artikel 18).

Tabel 6.2 bevat een overzicht van de voorzieningen die anno 1990 onder artikel 18 van de Wet Ziekenhuisvoorzieningen vallen en van het aantal ziekenhuizen dat een artikel 18-voorziening in huis heeft. In ongeveer de helft van de 182 ziekenhuizen in Nederland is een of meer artikel 18-voorzieningen aanwezig.

Tabel 6.2 Overzicht van alle huidige artikel 18-voorzieningen en een indicatie van het aantal ziekenhuizen met minimaal én artikel 18-voorziening (3112-1990)

\begin{tabular}{ll}
\hline Artikel 18-voorzieningen: & Aantal ziekenhuizen*: \\
\hline dialyse & 48 \\
niertransplantatie & 8 \\
radiotherapie & 21 \\
neurochirurgie (hoofdcentra) & 16 \\
hartchirurgie & 14 \\
postnataal chromosoomonderzoek en prenatale & 9 \\
diagnostiek & 50 \\
hartcatheterisatie, diagnostisch & 12 \\
$\quad$ therapeutisch & 11 \\
intensieve zorg voor zieke pasgeborenen & 12 \\
in vitro fertilisatie & 244 \\
\hline \hline & \\
\hline & Totaal: \\
* = algemene, categorale, academische en militaire ziekenhuizen, alsmede \\
$\quad$ dialysecentra (diatel)
\end{tabular}

Omtrent de kosten van topklinische functies is de informatie steeds schaars geweest. Het ministerie beschikt namelijk niet over een registratie van de totale geregistreerde exploitatiekostenstijgingen op het gebied van artikel 18-voorzieningen (Algemene Rekenkamer, 1990-1991). Een uitzondering hierop vormt een publicatie van Vos (1986), die getracht heeft de invloeden van artikel 18-voorzieningen op de kostenstructuur van algemene ziekenhuizen weer te geven. Ondanks het feit dat het onderzoek vanwege de kleine aantallen voorzieningen statistisch beter kon zijn gefundeerd, geeft is het een zekere indicatie. Vos concludeert dat slechts een beperkt aantal voorzieningen kostenverhogend werkt. Met name de therapeutische voorzieningen, zoals haemodialyse, radiotherapie en hartchirurgie werken kostenverhogend. Diagnostische voorzieningen daarentegen, zoals computertomografie, hartcatheterisatie en nucleaire geneeskunde, lijken minder kostenverhogend te werken.

Pas onlangs heeft het ministerie (1990-1991) gegevens bekend gemaakt omtrent kosten van artikel 18-voorzieningen. Deze zijn weergegeven in tabel 6.3. 
Tabel 6.3 Kosten van artikel 18-functies (1987-1989)

\begin{tabular}{|c|c|c|c|c|}
\hline \multirow[t]{2}{*}{ Artikel 18-functies: } & \multirow[t]{2}{*}{ Gemiddelde kosten: } & \multicolumn{3}{|c|}{$\begin{array}{l}\text { Kosten in miljoenen } \\
\text { guldens*: }\end{array}$} \\
\hline & & 1987 & 1988 & 1989 \\
\hline diatyse & $f 70.000,=$ per patiënt & 145 & 151 & 157 \\
\hline niertransplantatie & $f 75.000,=$ per transplantatio & 34 & 31 & 30 \\
\hline radiotherapie & $f \quad 200,=$ per zitting & 110 & 113 & 119 \\
\hline neurochirurgie & $f 14.000,=$ per operatie & 55 & 63 & 64 \\
\hline $\begin{array}{l}\text { hartchirurgie } \\
\text { - feitelijk } \\
\text { - afgesproken }\end{array}$ & $f_{\text {tie }} 14.900,=$ per open hart opera- & 145 & 161 & 166 \\
\hline $\begin{array}{l}\text { klinisch genetisch onderzoek } \\
\text { (postnataal chromosoom- } \\
\text { onderzoek en prenatale } \\
\text { diagnostiek) }\end{array}$ & $f 1.200,=$ per onderzoek & 19 & 22 & 22 \\
\hline $\begin{array}{l}\text { PTCA (hartcatheterisatie) } \\
\text { - leitelijk } \\
\text { - afgesproken }\end{array}$ & $f 7.800,=$ per behandeling & 36 & 39 & 46 \\
\hline $\begin{array}{l}\text { imtensieve zorg voor zieke pasge- } \\
\text { borenen }\end{array}$ & $\begin{array}{l}f 500.000=\text { per plaats } \\
f 40.000=\text { per patient }\end{array}$ & 62 & 68 & 83 \\
\hline in vitro fertilisatie & f $2.500_{1}=$ per behandeling & 4 & 6 & 10 \\
\hline \multicolumn{2}{|l|}{ Totaal: } & 610 & 654 & 697 \\
\hline \multicolumn{5}{|c|}{$\begin{array}{l}\text { * de kosten zijn berekend op basis van jaargegevens van ziekenhuizen over het aantal } \\
\text { verrichtingen (exclusief prijssijgingen en honoraria van specialisten); prijsniveau } 1989\end{array}$} \\
\hline \multicolumn{5}{|c|}{$\begin{array}{l}\text { Bron: Topklinische zorg 1991-1994 } \\
\text { Tweede Kamer 1990-1991, } 21 \text { 944, nr.1, p.12 }\end{array}$} \\
\hline
\end{tabular}

Uit tabel 6.3 blijkt dat de gemiddelde kosten per patiënt of per behandeling nogal uiteenlopen. Deze variëren namelijk van $f 1.200,=$ voor een klinisch genetisch onderzoek tot $f 75.000,=$ voor een niertransplantatie. Men moet zich echter wel goed realiseren dat de specialistenhonoraria niet meegerekend zijn en dat de werkelijke kosten dus hoger zijn.

\section{\$6.2.3 De procedure voor vergunningaanvragen}

Het "Besluit procedures voor bijzondere functies Wet Ziekenhuisvoorzieningen" (Wet Ziekenhuisvoorzieningen, 1986) regelt de totstandkoming van plannen voor bijzondere functies, de eisen waaraan vergunningsaanvragen moeten voldoen, hoe en door welke instanties deze worden beoordeeld en de gronden waarop een vergunning kan worden beperkt of geweigerd. De reden waarom hiervoor een apart besluit is opgesteld is het feit, dat deze procedure afwijkt van de planningsartikelen van de Wet Ziekenhuisvoorzieningen. De planningsartikelen gaan immers uit van het regio-niveau, terwijl de planning krachtens artikel $18 \mathrm{op} \mathrm{landelijk} \mathrm{niveau}$ plaatsvindt.

De eerste fase in de procedure voor bijzondere functies is de opstelling van plannen voor bijzondere functies. Dit gebeurt als volgt: 
1. de staatssecretaris bepaalt in een ontwerp-plan de omvang van de behoefte aan een categorie van bijzondere functies en de manier waarop in die behoefte kan worden voorzien;

2. voor advies wordt het ontwerp-plan gezonden naar:
a. de Gezondheidsraad of de Nationale Raad voor de Volksgezondheid (over de voorgestelde omvang van de behoefte);
b. de colleges van Gedeputeerde Staten (met betrekking tot de wijze waarop in de behoefte kan worden voorzien) en
c. het College voor Ziekenhuisvoorzieningen (eveneens omtrent de omvang en omtrent de invulling van de behoefte);

Overigens kan hetgeen vermeld is onder a., b. en c. gelijktijdig worden afgewerkt, wanneer het om eenvoudige zaken gaat. Betreft het echter ingewikkelde aangelegenheden, dan kan worden besloten om als eerste a. en c. (alleen met betrekking tot de omvang) te doorlopen en daarna pas b. en c. (over de invulling). Deze gang van zaken is toegevoegd bij de wijziging van 1984 .

In de praktijk gebeurt het gelijktijdig raadplegen van adviesorganen echter nauwelijks (College voor Ziekenhuisvoorzieningen, 1987).

3. de staatssecretaris stelt het plan vast. In artikel 18-jargon heet een plan een "planningsbesluit". Hierna wordt het planningsbesluit bekend gemaakt in de Staatscourant. Het blift in principe vier jaar van kracht.

Een planningsbesluit bevat de volgende onderdelen:

- een aanduiding van het maximale aantal plaatsen, centra of apparaten waaraan (volgens de Staatssecretaris, op advies van de Gezondheidsraad of de Nationale Raad, het College voor Ziekenhuisvoorzieningen en Gedeputeerde Staten) behoefte bestaat;

- het tijdstip van inwerkingtreding;

- een bijlage, die bestaat uit:

* de behoefte aan de betreffende functie;

* de wijze waarop in de behoefte kan worden voorzien;

* de beëindiging van de betreffende functie;

- een toelichting bij besluit en bijlage.

De tweede fase in de artikel 18-procedure bestaat uit het aanvragen van een vergunning door de instellingen. Dit verzoek dient te zijn opgesteld op de manier die wordt voorgeschreven in de bijlage ("bijlage gegevensverstrekking bil de aanvraag om een vergunning voor een bijzondere functie"). behorende bij het "Besluit procedures voor bijzondere functies Wet Ziekenhuisvoorzieningen" (Wet Ziekenhuisvoorzieningen, 1986). Deze bijlage vraagt een groot aantal gegevens, te weten: algemene gegevens over de betrokken instelling, specifieke gegevens omtrent de aanvraag, een schets van de huidige en de toekomstige situatie van de voorziening, een cijfermatige onderbouwing hiervan. Welke gegevens moeten worden verstrekt, verschilt per voorziening.

Wanneer ten behoeve van de betreffende functie tevens bouwwerkzaamheden noodzakelijk zijn, dient dit te worden aangegeven. Hiertoe moet verder de procedure worden gevolgd die voor de bouw van voorzieningen gebruikelijk is.

Overigens moet een instelling tegenwoordig in één brief gelijktijdig een verklaring en een vergunning en een verklaring voor de benodigde bouw voor de betreffende bijzondere functie aanvragen. Een verklaring wordt afgegeven wanneer een functie past binnen een plan of, indien er nog geen plan is, dat er behoefte bestaat aan de functie. Een vergunning wordt verleend wanneer vanuit doelmatigheids- en kostenoogpunt geen bezwaar bestaat tegen realisering van een bepaalde functie (Wet Ziekenhuisvoorzieningen, 1986). Eerder waren hiervoor drie afzonderlijke verzoeken nodig. 
De derde fase behelst de beoordeling van de ingediende vergunningaanvragen. Allereerst wint de staatssecretaris binnen één maand na ontvangst van een aanvraag advies in bij het College voor Ziekenhuisvoorzieningen en bij Gedeputeerde Staten van de provincie waarin de betrokken functie zich bevindt en eventueel van andere provincies. Vervolgens brengen zowel het College voor Ziekenhuisvoorzieningen als Gedeputeerde Staten in principe binnen zes maanden na ontvangst van het verzoek om advies (deze termijn kan in bijzondere gevallen verkort of verlengd worden) advies uit. Hierna beslist de staatssecretaris binnen drie maanden na ontvangst van de adviezen (of drie maanden nadat de adviestermijn is verstreken) over de honorering dan wel afwijzing van de vergunningaanvraag. Deze fase neemt dus formeel maximaal tien maanden in beslag.

De vierde fase tenslotte omvat de bekendmaking van het besluit aan de aanvrager. Zowel in geval van een afwijzing als wanneer het een toewijzing betreft dient het besluit met redenen te zijn omkleed en vergezeld van de uitgebrachte adviezen. Een besluit wordt bekend gemaakt in de Nederlandse Staatscourant en toegestuurd aan de organen die erover hebben geadviseerd.

De hierboven beschreven procedure is weergegeven in schema 6.2 .

Schema 6.2 Vergunningverstrekking volgens de wettekst van de Wet Ziekenhuisvoorzieningen

\begin{tabular}{|c|c|c|c|}
\hline Fasen: & Activiteiten: & Actoren: & \\
\hline 1 & $\begin{array}{l}\text { opstelling plannings- } \\
\text { besluit voor bijzondere } \\
\text { functies }\end{array}$ & staatssecretaris & $\begin{array}{l}\rightarrow \text { Gezondheidsraad / Nati- } \\
\text { onale Raad } \\
\rightarrow \text { Gedeputeerde Staten } \\
\rightarrow \text { College voor Ziekenhuis- } \\
\text { voorzieningen }\end{array}$ \\
\hline 2 & aanvragen vergunning & instellingen & \\
\hline 3 & $\begin{array}{l}\text { beoordeling vergun- } \\
\text { ningaanvraag }\end{array}$ & staatssecretaris & $\begin{array}{l}\rightarrow \text { College voor Ziekenhuis- } \\
\text { voorzieningen } \\
\rightarrow \text { Gedeputeerde Staten }\end{array}$ \\
\hline 4 & $\begin{array}{l}\text { bekendmaking besluit } \\
\text { aanvragen }\end{array}$ & staatssecretaris & \\
\hline
\end{tabular}

Deze procedure brengt met zich dat instellingen volgens de wettekst, in theorie dus, minimaal tien maanden en maximaal veertien maanden, nadat zij een aanvraag hebben ingediend, een toewijzing danwel een afwijzing van hun vergunningaanvraag kunnen verwachten.

\section{§6.2.4 Kritiek op de werking van artikel 18}

Kritiek op de werking van artikel 18 bestaat in feite al sinds de inwerkingtreding van deze regeling en is niet gering. De meest genoemde punten van kritiek zijn de volgende: 
- De procedure is te lang, te traag en daardoor te tijdrovend;

Door de lange adviesprocedure en de lange tijd die gemoeid is met de totstandkoming van de planningsbesluiten, in een aantal gevallen ontbreekt een planningsbesluit zelfs, is de maatregel traag. Daardoor is achterstand ontstaan in de afwikkeling. Er zijn zelfs voorzieningen die vier jaar onder artikel 18 hebben geressorteerd en er weer uit zijn verwijderd zonder dat ooit vergunningen zijn verleend. De besluitvorming bij het ministerie blijkt het traagst en niet zozeer de advisering door externe organen (College voor Ziekenhuisvoorzieningen, 1979, 1987 en 1989; Algemene Rekenkamer, 1986-1987 en 1990-1991; Commissie Dekker, 1987; Nationale Ziekenhuisraad, 1988), zoals vaak wordt gesuggereerd (Topklinische zorg 1991-1994, 1990-1991).

Academische ziekenhuizen zijn lange tijd buiten het artikel 18-regime gebleven; Academische ziekenhuizen zijn bij uitstek instellingen waar topklinische zorg wordt verstrekt. Het had dus voor de hand gelegen artikel 18 ook daarop van toepassing te verklaren. Tien jaar na de inwerkingtreding is dit dan per 1 januari 1988 toch gebeurd (College voor Ziekenhuisvoorzieningen, 1976 en 1986; Algemene Rekenkamer, 1986-1987).

- Het "voor de bui binnen willen zijn";

Instellingen schaffen in een versneld tempo bijzondere voorzieningen aan met de verbodsbepaling in het vooruitzicht (College voor Ziekenhuisvoorzieningen, 1976 en 1979).

- "Eens 18 altijd 18";

Een aanwijzing als artikel 18-voorziening blijkt vrij definitief van karakter. Wanneer een voorziening eenmaal onder het artikel 18-regime terecht is gekomen, is de kans niet zo groot dat deze voorziening er nog onderuit komt. In de praktijk is gebleken dat het predikaat "bijzonder" voor een voorziening meestal blijvend is (College voor Ziekenhuisvoorzieningen, 1987 en 1989; Memorie van toelichting bij wetsvoorstel tot wijziging van de Wet op het Wetenschappelijk Onderwijs en de Wet Ziekenhuisvoorzieningen, 1988-1989). Tot dusver zijn nog slechts twee voorzieningen van de dertien geschrapt in de vijftien jaren dat de regeling van kracht is.

- Onduidelijke samenhang tussen artikel 18 en andere wettelijke regelingen;

De relatie tussen artikel 18 en de erkenning ex artikel 8 a van de Ziekenfondswet en artikel 8 van de Algemene Wet Bijzondere Ziektekosten is onduidelijk. Ziekenhuizen kunnen voor een bijzondere voorziening een erkenning bezitten krachtens de Ziekenfondswet of de Algemene Wet Bijzondere Ziektekosten, zonder te beschikken over een vergunning ex artikel 18. Ook de verhouding tot de budgettering krachtens de Wet Tarieven Gezondheidszorg is niet helder (College voor Ziekenhuisvoorzieningen, 1987 en 1989; Algemene Rekenkamer, 1990-1991).

- Gebrek aan informatie over kosten en effecten;

Informatie omtrent de kosten en baten van voorzieningen ontbrak tot nu toe en is pas sinds kort beschikbaar (College voor Ziekenhuisvoorzieningen, 1987; Algemene Rekenkamer, 1990-1991; Topklinische zorg in de jaren '91-'94, 1990; Topklinische zorg 1991-1994, 1990-1991).

- Uniform en duidelijk vastgelegde criteria voor het in- en uittredebeleid ontbreken nog;

De wettekst bepaalt dat "gewichtige belangen" aanleiding kunnen geven tot toepassing van artikel 18 op een voorziening. Kosten en kwaliteit worden als 
argumenten genoemd. Naderhand worden tijdens de behandeling in de Tweede Karner ook "schaarse deskundigheid", "zeldzaamheid" en "grootschaligheid" genoemd (College voor Ziekenhuisvoorzieningen, 1987). Deze criteria zijn echter nooit uitgewerkt. Een voorbeeld is de niersteenvergruizer, die volgens deze criteria eveneens onder artikel 18 gebracht had moeten worden. Maar dit niet is gebeurd. In de praktijk is steeds van geval tot geval bekeken of een bepaalde voorziening het predikaat artikel 18 moest krijgen (Nationale Ziekenhuisraad, 1988; Algemene Rekenkamer, 1990-1991).

\section{- De informatievoorziening is niet adequaat;}

De informatie via de advisering is veelal verouderd als gevolg van de lange tijd die de procedure in beslag neemt (College voor Ziekenhuisvoorzieningen, 1987; Algemene Rekenkamer, 1990-1991).

- De spreiding in planningsbesluiten sluit doorgaans aan bij de bestaande situatie; Ziekenhuizen die een topklinische voorziening al toepasten voor de inwerkingtreding van een planningsbesluit konden meestal rekenen op toestemming om dit te continueren (Algemene Rekenkamer, 1990-1991).

\section{- Sturing op exploitatiekosten is niet goed mogelijk;}

De financiering is een zaak van de zorgverzekeraars en de ziekenhuizen die gezamenlijk produktie-afspraken maken (Algemene Rekenkamer, 1990-1991).

- De uitvoering van het artikel 18 beleid wordt nauwelijks gecontroleerd;

Bij de afgifte van een artikel 18-vergunning controleert het ministerie wel of een instelling aan de eisen van het planningsbesluit voldoet. Daarna vindt geen controle meer plaats. Evenmin worden instellingen gecontroleerd waarvan een vergunningaanvraag is geweigerd (Algemene Rekenkamer, 1990-1991).

Ondanks deze kritiek, die reeds dateert uit de beginjaren van artikel 18, duurde het tot 1989 voordat de wetgeving werd aangepast (zie hierover de paragrafen 6.2.3 en 6.3.1).

\section{§6.3 De meting van de bestuurskosten van artikel 18}

Hiervoor is de procedure beschreven die moet worden gevolgd om in aanmerking te komen voor een vergunning voor bijzondere voorzieningen. Nu zal weergegeven worden, hoeveel tijd in de praktijk is verstreken tijdens het aanvragen van een vergunning voor een artikel 18-voorziening. Hierbij wordt onderscheid gemaakt tussen de doorlooptijd van de totstandkoming van de planningsbesluiten en de doorlooptijd van de aanvragen voor artikel 18-vergunningen. In het eerste geval zal worden nagegaan hoeveel tijd verstrijkt voordat een planningsbesluit in werking kan treden. In het laatste geval zal worden geïnventariseerd hoeveel tijd verstrijkt voordat instellingen bericht krijgen omtrent hun vergunningaanvragen.

De bestuurskosten zijn in hoofdstuk 2 gedefinieerd als de kosten van de bestuurlij$k e$ infrastructuur bij overheden en particulieren die het gevolg zijn van overheidsbesturing. Hiertoe behoren de kosten die zowel overheden, als instellingen als ook verzekeraars en adviesorganen maken als gevolg van de uitvoering van een bepaalde beleidsmaatregel. Toegepast op artikel 18 van de Wet Ziekenhuisvoorzieningen bestaat een deel van de bestuurskosten die overheden maken uit kosten van de totstandkoming van regels en van de uitvoering hiervan. Tot de totstandko- 
ming van regels kan men rekenen de opstelling van de planningsbesluiter. Tot de uitvoering van regels kan men rekenen het beoordelen van vergunningaanyagen. Bij instellingen maken de kosten van de behnvloeding van de overheid bij de beoordeling van vergunningaanvragen deel uit van de bestuurskosten.

Een extra indicatie van de bestuurskosten is de zogeheten bostuurlike drukte. ofwel het aantal instanties dat betrokken is bij de vitvoering van artikel 18. Dit is een aanzienlijk aantal, zoals blijkt uit schema 6.3.

Schema 6.3 Instanties die zijn betrokken bij de uitvoering van artikel 18 door de Limburgse ziekenhuizen

\begin{tabular}{ll}
\hline Buiten de provincie: & Binnen de provincie: \\
\hline staatssecretaris & ziekenhuizen: \\
Raad van State & - specialisten \\
College voor Ziekenhuisvoorzieningen & - bestuur \\
Gezondheidsraad & - directie \\
Nationale Raad voor de Volksgezond. & - stafafdeling \\
heid & Provinciale Raad voor de Volksgezond- \\
colleges van Gedeputeerde Staten van & heid \\
andere provincies & samenwerkingsverbanden van zieken- \\
& huizen \\
& financiers \\
\hline
\end{tabular}

Allang voordat instellingen daadwerkelijk te maken krijgen met het aanvragen van vergunningen hebben de staatssecretaris, de adviesorganen en alle Gedeputeerde Staten zich gedurende ettelijke jaren bezig gehouden met artikel 18. Dit brengt een aanzienlijke tijdsinvestering en een grote hoeveelheid bestuurskosten met zich.

Wanneer instellingen eenmaal met artikel 18 te maken krijgen, kost dit weer een dosis tijd. Met het aanvragen van een vergunning dient een instelling legio gegevens te verschaffen omtrent capaciteit, personeel, patiëntenstromen en investeringen. Daarna begint het wachten op antwoord en alle activiteiten die daarmee gepaard gaan. Hoe langer men moet wachten, des te meer (lobby)activiteiten worden ondernomen.

Een lange doorlooptijd betekent dus zowel voor degenen die de planningsbesluiten en wat daaraan vooraf gaat opstellen als voor de instellingen zeker meer tijd en bestuurskosten, dan een korte doorlooptijd. Bovendien is de kans groot dat ziekenhuizen of "onafhankelijke" organisaties, zoals een patiëntenvereniging, toch alvast apparatuur aanschaffen, wanneer de vergunning lang op zich laat wachten. Dit impliceert dat de doorlooptijd in ieder geval een aanduiding geeft van de hoogte van de bestuurskosten.

Voordat meting kan plaatsvinden, moeten eerst een aantal expliciete keuzen gemaakt worden. In het onderstaande wordt hierop ingegaan.

De afbakening van de doorlooptijd van artikel 18 van de Wet Ziekenhuisvoorzieningen is als volgt gebeurd. Als beginpunt voor de doorlooptijd van de totstandkoming van de planningsbesluiten is uitgegaan van het "Besluit Bijzondere Ziekenhuisvoorzieningen" (1974). Als beginpunt van de doorlooptijd voor aanvragen door instellingen is gekozen voor de datum waarop de betreffende instelling de vergunningaanvraag indient bij de staatssecretaris. Dit is een praktische keuze: de datum wordt vermeld op de vergunningaanvraag en is dus eenduidig vast te stellen en na te gaan. Het eigenlijke proces van het aanvragen van een vergunning begint in de instellingen natuurlijk al eerder. Veelal komt bij de directies een 
verzoek terecht van de kant van specialisten. Zij doen een voorstel omtrent aan te schaffen apparatuur en verzoeken de directie zich voor de aanschaf van deze apparatuur in te zetten. De directies van hun kant hebben de specialisten nodig in verband met de informatie die nodig is voor het aanvragen van een vergunning. Zodra deze activiteiten op gang komen, worden in feite reeds bestuurskosten gemaakt. Echter, het betreft vaak in eerste instantie mondeling overleg over en weer, alvorens een formeel verzoek wordt ingediend. Hierdoor wordt het moeilijk het exacte beginpunt te bepalen. Een toerekeningsprobleem betreft verder het feit dat overleg tussen directie en medische staf omtrent de aanschaf van apparatuur ook zou hebben plaatsgevonden zonder het bestaan van artikel 18. Vandaar dat gekozen is voor het formele begin. Als eindpunt is gekozen voor het moment waarop de instelling bericht, positief dan wel negatief, krijgt van de staatssecretaris. Dit is weergegeven in schema 6.4 .

Schema 6.4 Bepaling van de doorlooptijd van artikel 18

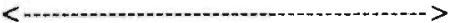

$<--\cdot-\cdot-\cdot-\cdot$

totstandkoming planningsbesluit afhandeling vergunningaanvraag

Bij de gegevensverzameling zijn alle artikel 18-voorzieningen betrokken.

Benadrukt moet worden dat het hier slechts gaat om een benadering van de bestuurskosten door de doorlooptijd te bepalen. Nauwkeurige meting van bestuurskosten is onmogelijk. In deze studie is in het geval van de bepaling van de bestuurskosten van de afhandeling van de vergunningaanvragen dan ook sprake van een minimale schatting van de bestuurskosten. Aangezien alleen de formele tijd wordt meegerekend en niet de informele (voordat de eigenlijke aanvraag is ingediend) is automatisch sprake van onderschatting.

Ten aanzien van de dataverzameling moeten eveneens een aantal aspecten verduidelijkt worden. Het gaat hier om de manier waarop de gegevens zijn verzameld.

Bij het inventariseren was de werkwijze als volgt. Eerst is in het archief van de Provinciale Raad voor de Volksgezondheid nagegaan welke Limburgse ziekenhuizen over welke artikel 18-voorzieningen beschikken. Voor zover mogelijk is ook toen reeds achterhaald wanneer deze vergunningen zijn aangevraagd en verstrekt. Vervolgens zijn de directiesecretariaten telefonisch benaderd om de bedoeling van het onderzoek uit te leggen. Hierop hebben zij een schriftelijke lijst gekregen met het verzoek de reeds gevonden data te controleren en de overige aan te vullen. In het algemeen werd de informatie vrij snel na het verzoek verstrekt. Was dit niet het geval, dan werd opnieuw contact opgenomen. Dit had tot resultaat dat van alle ziekenhuizen gegevens zijn binnen gekomen. Desalniettemin is niet de doorlooptijd van alle aanwezige artikel 18-voorzieningen bekend. Van een aantal aanvragen bleek de doorlooptijd helaas niet te achterhalen, omdat de gegevens onvindbaar waren of ontbraken.

Eén ziekenhuis gaf er de voorkeur aan de dataverzameling te laten plaatsvinden door de onderzoeker, zodat deze zelf het archief kon raadplegen. Toen werd overigens pas goed duidelijk dat het geen eenvoudig karwei is, omdat de gevoerde correspondentie veelal niet in één dossier zit, maar in diverse. Zo waren de mogelijke trefwoorden: de artikel 18-voorziening, het specialisme waartoe de voorziening behoort, vergunningaanvragen. Bovendien nam de afhandeling van de meeste vergunningaanvragen ettelijke jaren in beslag. Dit maakte de gegevensverzameling ook niet eenvoudiger. 
Bij de berekening van de doorlooptijd van de vergunningaanvragen is per categorie artikel 18-voorzieningen de gemiddeld benodigde tijd bepaald. Dit houdt het volgende in: wanneer de vergunningaanvraag voor bijvoorbeeld dialyse in het ene ziekenhuis éen jaar in beslag nam in een ander ziekenhuis drie jaar dan werd de gemiddelde doorlooptijd bepaald op anderhalf jaar.

\section{§6.3.1 De doorlooptijd van de totstandkoming van planningsbesluiten}

In 1974 werd artikel 18 in de uitvoeringsmaatregel het "Besluit bijzondere ziekenhuisvoorzieningen" van toepassing verklaard op niertransplantaties en chronisch intermitterende haemodialyse. Het besluit werd in het Staatsblad gepubliceerd, maar kon niet in werking treden. Dit kwam doordat de planningsbesluiten nog tot stand moesten komen. Daarom werd in 1976 een wijzigingsbesluit ingesteld, waardoor het besluit wel in werking kon treden. Dit gebeurde overigens nog voordat de Wet Ziekenhuisvoorzieningen was gewijzigd.

Op 19 april 1984 trad het Besluit bijzondere functies Wet Ziekenhuisvoorzieningen in werking. Vanaf dat moment ressorteren tien voorzieningen onder artikel 18 gebracht. Voor al deze voorzieningen is vanaf dat moment een vergunning vereist.

Op 14 november 1984 ontvingen de ziekenhuizen een circulaire van de staatssecretaris. Hierin kondigde deze aan dat de afzonderlijke ministeriële planningsbesluiten in voorbereiding waren. Verder gaf hij aan dat, zolang de planningsbesluiten nog niet gereed waren, de aanvragen zouden worden getoetst aan de toetsingscriteria van de (formeel inmiddels vervallen) besluiten, danwel aan adviezen van de Gezondheidsraad en het College voor Ziekenhuisvoorzieningen omtrent de afzonderlijke voorzieningen.

De ziekenhuizen werden verzocht binnen drie maanden na het verschijnen van de brief continueringsaanvragen in te dienen voor de artikel 18-voorzieningen die men toen reeds in huis had. Wanneer men al in het bezit was van een vergunning voor chronisch intermitterende haemodialyse, niertransplantatie, en megavolttherapie en/of computertomografie toepaste, behoefde hiervoor geen nieuwe vergunning aangevraagd te worden (Wet Ziekenhuisvoorzieningen, 1986)

Veel ziekenhuizen hebben aan deze oproep gehoor gegeven (zie hierna). De staatssecretaris heeft deze aanvragen ter advisering aan het College voor Ziekenhuisvoorzieningen voorgelegd. Het College heeft de staatssecretaris er vervolgens op gewezen dat het behandelen van deze aanvragen door het College "nagenoeg onmogelijk is vanwege het feit dat de aanwijzing van de tien bijzondere functies niet vergezeld is gegaan van de vereiste planningsbesluiten, waaraan de aanvragen zouden kunnen worden getoetst" (brief 16-2-1987).

De staatssecretaris heeft het College daarop verzocht, in afwachting van het gereedkomen van de toegezegde planningsbesluiten, de voor 14 november 1984 ingediende aanvragen af te doen op de wijze zoals aangegeven in het "bij die brief gevoegde schema". Dit laatste wil zeggen: te toetsen aan de vervallen besiuiten casu quo adviezen.

Verder vroeg de staatssecretaris het College voor Ziekenhuisvoorzieningen de na 14 november 1984 ingediende aanvragen niet in behandeling te nemen. Afdoening hiervan zou pas dienen plaats te vinden binnen de daartoe in het Besluit procedures voor bijzondere functies Wet Ziekenhuisvoorzieningen gestelde termijn van drie 
maanden. Met uitzondering van de niertransplantatie en de computertomografie zijn op dat moment echter nog geen planningsbesluiten vastgesteld.

Het College voor Ziekenhuisvoorzieningen was intussen de mening toegedaan, dat door de vertraagde besluitvorming het bij het College inmiddels gecumuleerde aanvragenbestand qua gegevensmateriaal was verouderd. Dit betrof gegevens die ziekenhuizen bij hun aanvragen moesten voegen. Zij dateerden al van voor februari 1985. Daarom was het College van oordeel dat "het op bestuurlijke gronden niet verantwoord is om de advisering over de voorliggende continueringsaanvragen (maar liefst 210 in getal!; College voor Ziekenhuisvoorzieningen, 1988) ex artikel 18 Wet Ziekenhuisvoorzieningen langer aan te houden en de instellingen verder in het ongewisse te laten over de verdere afhandeling van hun aanvragen" (brief 16-21987). In deze constatering betrok het College mede het feit dat in een niet gering aantal gevallen noodzakelijke vervanging van apparatuur moet plaatsvinden.

Het College was voorts van mening dat er onvoldoende gronden waren om de aanvragen af te wijzen. Het stelde daarom voor om voorwaardelijke goedkeuring te verlenen indien de functie al voor het Besluit aantoonbaar aanwezig was en de functie voldeed aan de begripsomschrijving uit het betreffende concept-planningsbesluit. Ten aanzien van de vervangingsaanvragen deed het College het voorstel om deze in te willigen voor zover voor die bijzondere functies een vergunning aanwezig is en het een noodzakelijke vervanging zonder capaciteitsuitbreiding betreft. Overigens merkte het College wel op dat het hier om een eenmalige oplossing ging (College voor Ziekenhuisvoorzieningen, 1988).

De staatssecretaris ging hiermee akkoord (zie hierna).

Tabel 6.4 biedt een overzicht van het aantal vergunningaanvragen die in de loop der jaren door het College voor Ziekenhuisvoorzieningen en het ministerie waren af te handelen.

Tabel 6.4 Af te handelen vergunningaanvragen bij het College voor Ziekenhuisvoorzieningen en de directie Ziekenhuiszorg en Topzorg van het ministerie van Welzijn, Volksgezondheid en Cultuur

\begin{tabular}{|c|c|c|c|}
\hline Jaar: & College: & Jaar: & Ministerie: \\
\hline $31-12-1984$ & $11(1)$ & $. .-1-1985$ & gegevens niet meer beschikbaar \\
\hline $31-12-1985$ & $229(174)$ & $. .-1-1986$ & gegevens niet meer beschikbaar \\
\hline $31-12-1986$ & $250(183)$ & $. .-1-1987$ & $456 \quad(334)$ \\
\hline $31-12-1987$ & $70(2)$ & $. .-1-1988$ & $(309)$ \\
\hline $31-12-1988$ & $15(6)$ & $. .-1-1989$ & $(16)$ \\
\hline $31-12-1989$ & $3(0)$ & $. .-1-1990$ & (19) \\
\hline Totaal: & $578 \quad(366)$ & & $1018 \quad(678)$ \\
\hline
\end{tabular}

( ) = waarvan continueringsaanvragen

Bron: Algemene Rekenkamer

Regulering van topklinische zorg

Tweede Kamer 1990-1991, 22 056, nrs.1-2, p.29 
In de nota "Werken aan zorgvernieuwing" (1989-1990) spreekt de staatssecretaris het voornemen uit artikel 18 te herformuleren. Het is de bedoeling dat een "slagvaardiger beleid" (p.30) mogelijk wordt, waardoor tijdig op nieuwe ontwikkelingen, zoals orgaantransplantaties, kan worden ingespeeld. De staatssecretaris is van plan topklinische zorg te concentreren. Bovendien zullen functies buiten artikel 18 worden gebracht wanneer de kosten niet meer buitensporig hoog zijn en de kwaliteit is bewezen.

Waarschijnlijk mede gezien de kritiek van de adviserende instanties heeft de regering een wetsvoorstel ingediend om artikel 18 aan te passen (1988-1989). De belangrijkste wijzigingsvoorstellen zijn de volgende:

- de vergunningplicht eindigt na ten hoogste vier jaar;

- de aanwijzing van functies geschiedt niet langer bij algemene maatregel van bestuur, maar op basis van een ministerieel besluit;

- de huidige artikel 18-functies worden heroverwogen;

- de procedures worden vereenvoudigd en gedereguleerd;

- in het Financieel Overzicht wordt expliciet aangegeven welke financiële ruimte beschikbaar is voor de planning en intensivering van de top-klinische zorg. inclusief die in academische ziekenhuizen.

De doorlooptijd die veroorzaakt wordt door de verwikkelingen rondom de totstandkoming van de planningsbesluiten ex artikel 18 is weergegeven in tabel 6.5.

\begin{tabular}{|c|c|c|c|c|c|}
\hline Voorzieningen: & $\begin{array}{l}\text { Besluit Bijzon- } \\
\text { dere Zieken- } \\
\text { huiswoorzienin- } \\
\text { gen: }\end{array}$ & $\begin{array}{l}\text { Tijdelijke Rege- } \\
\text { ling: }\end{array}$ & $\begin{array}{l}\text { Concept- } \\
\text { planningsbesluit: }\end{array}$ & $\begin{array}{l}\text { Plannings- } \\
\text { besluit: }\end{array}$ & $\begin{array}{l}\text { Totale door- } \\
\text { looptijd pro- } \\
\text { cedure: }\end{array}$ \\
\hline dialyso & 19 juli 1974 & 14 mei 1976 & 24 dec. 1986 & 4 sept. 1987 & 158 mnd. \\
\hline niertransplentatle & 19 juli 1974 & n.v.t. & 25 okt. 1985 & 3 okt 1986 & 147 mnd. \\
\hline radiotherapio & $\begin{array}{l}11 \text { dec. } 1978 \\
24 \text { nov. } 1983\end{array}$ & n.v.t. & 13 tobr. 1986 & 22 juli 1987 & 104 mnd. \\
\hline neurochirurgie & 24 nov. 1983 & n.v.t. & 10 dec. 1985 & 4 sept. 1987 & 46 mind. \\
\hline hartchirurgie & 24 nov. 1983 & n.v.t. & 19 sug. 1987 & 9 jan. 1989 & 62 mnd. \\
\hline $\begin{array}{l}\text { postnataal chromosoom- } \\
\text { onderoek en prenatale } \\
\text { diagnastiok }\end{array}$ & 24 nov. 1983 & n.v.t. & 25 tobr. 1986 & 22 juli 1987 & 44 mnd. \\
\hline hartcathetorisatie & 24 nov. 1983 & 15 juni 1983 & 30 jan. 1986 & 22 juli 1987 & 44 mnd. \\
\hline intensieve neonatologie & 24 nov. 1983 & n.v.t. & $14 \mathrm{mrt} .1986$ & 29 sept. 1987 & 46 mnd. \\
\hline in vitro fertilisatie & n.v.t. & 18 juli 1985 & 16 dec. 1988 & 20 juli 1989 & 48 mnd. \\
\hline \multicolumn{6}{|c|}{ Per 9 nov. 1988 buiten artikel 18 : } \\
\hline computer tomografie & 24 nov. 1983 & $\begin{array}{l}1 \text { apr. } 1981 \\
1 \text { apr. } 1983\end{array}$ & 24 sept. 1984 & $\uparrow 1$ juli 1986 & $32 \mathrm{mnd}$ \\
\hline nucleaire geneeskunde & 24 nov. 1983 & n.v.t & 10 dec. 1985 & $\begin{array}{l}\text { is er niet } \\
\text { gekomen }\end{array}$ & $25 \mathrm{mnd}$. \\
\hline
\end{tabular}

Gemiddeld:

69 mnd.

n.v.t. = beslutt of rageling is er niet gekomen

De gemiddelde doorlooptijd van de totstandkoming van de planningsbesluiten bedraagt 69 maanden ofwel vijf jaar en 9 maanden. 


\section{§6.3.2 De doorlooptijd van de afhandeling van vergunningaanvragen}

Voor alle algemene ziekenhuizen in de provincie Limburg is, voor zover zij in het bezit zijn van artikel 18-voorzieningen, nagegaan hoeveel tijd telkens is verstreken tussen het aanvragen van een vergunning en het krijgen van antwoord op deze aanvraag.

De meeste aanvragen voor dialyse dateren logischerwijs van eind jaren zeventig. Het planningsbesluit dateert immers van 1974. De afhandeling van de aanvragen nam nooit meer dan anderhalf jaar in beslag. De continueringsaanvragen uit de jaren tachtig kostten twee of drie jaren.

De betreffende vergunning voor niertransplantatie was al voor 14 november 1984 afgegeven en behoefde niet opnieuw te worden aangevraagd.

De gegevens betreffende de functie radiotherapie zijn zo onvolledig dat hierover nauwelijks een uitspraak gedaan kan worden. Dit gebrek is terug te voeren op het feit dat radiotherapie al sinds 1974 een bijzondere voorziening is en gegevens uit die tijd moeilijk te achterhalen zijn.

Van alle aanvragen voor neurochirurgie heeft alleen het hoofdcentrum bericht gehad dat de continueringsaanvraag is goedgekeurd. De subcentra wachten reeds sedert 1985 of 1988 op afhandeling van hun verzoek om continuering of oprichting.

Hartchirurgie is in Limburg voorbehouden aan het academisch ziekenhuis. De besluitvorming over de aanvraag nam twee tot vier jaar in beslag. Deze twee tijden voor eenzelfde voorziening zijn te verklaren doordat op twee verschillende tijdstippen een aanvraag is ingediend voor eenzelfde voorziening.

Op de aanvraag voor postnataal chromosoomonderzoek en prenatale diagnostiek kwam twee jaar na de indiening bericht van de staatssecretaris.

Voor de aanvragen voor hartcatheterisatie duurde het vijf jaar voordat continuering werd verleend. In twee gevallen werden, nadat de aanvraag was geweigerd, gedurende vijf jaar verzoeken ingediend of werd in beroep gegaan tegen de weigering.

Intensieve neonatologie is een verhaal apart, aangezien onenigheid bestond over wat men onder "intensief" moest verstaan. In afwachting van een oplossing hiervoor zijn de verzoeken aangehouden gedurende minimaal vijf jaar.

Aan de goedkeuring van in vitro fertilisatie is uitgebreid onderzoek voorafgegaan. Eerst moest de effectiviteit van deze behandelmethode worden aangetoond, alvorens de behandeling zou worden vergoed door de ziekenfondsen. Aan de resultaten hiervan is ook het al dan niet toekennen van een vergunning ex artikel 18 gekoppeld.

De berichten naar aanleiding van de aanvragen voor computer tomografie zijn één tot drie jaar na indiening van de aanvraag binnengekomen.

Voor nucleaire geneeskunde is nooit een Planningsbesiuit afgekondigd. Sinds 1985 lopen wel zes aanvragen voor continuering. Hierop is echter nooit ingegaan. Door intrekking van nucleaire geneeskunde als artikel 18-voorziening per 8 november 
1988 zijn de aanvragen overbodig geworden. Desondanks waren de berichten in december 1990 nog niet binnen.

Een overzicht van de gevonden doorlooptijden wordt weergegeven in tabel 6.6. In de tweede kolom wordt weergegeven hoeveel artikel 18-plaatsen genoemd worden in de betreffende planningsbesluiten. Zo wordt in het planningsbesluit niertransplantatie slechts één ziekenhuis genoemd waar niertransplantaties mogen worden uitgevoerd en dat is het Academisch Ziekenhuis in Maastricht. Niet in alle planningsbesluiten worden alle instellingen genoemd die voor een vergunning in aanmerking komen. In de planningsbesluiten hartcatheterisatie, radiotherapie en in vitro fertilisatie wordt dit achterwege gelaten. In de derde kolom staat het resultaat van de inventarisatie van de gegevens van de Provinciale Raad voor de Volksgezondheid. Hieruit komt naar voren in hoeveel instellingen de artikel 18-voorzieningen aanwezig zijn of een vergunningaanvraag is ingediend. Kolom vier geeft aan hoeveel aanvragen de begin- en eindtijd voorhanden is. En in kolom vijf is de geînventariseerde doorlooptijd weergegeven. 
Tabel 6.6 De doorlooptijd van vergunningaanvragen

\begin{tabular}{|c|c|c|c|c|c|}
\hline $\begin{array}{l}\text { Voorzienin- } \\
\text { gen: }\end{array}$ & $\begin{array}{l}\text { Genoemd } \\
\text { in plan- } \\
\text { nings- } \\
\text { besluiten: }\end{array}$ & $\begin{array}{l}\text { Aantal arti- } \\
\text { kel 18-voor- } \\
\text { zieningen } \\
\text { aanwezig of } \\
\text { aange- } \\
\text { vraagd: }\end{array}$ & $\begin{array}{l}\text { Aantal artikel } \\
18 \text {-voorzienin- } \\
\text { gen waarover } \\
\text { gegevens } \\
\text { voor handen }\end{array}$ & $\begin{array}{l}\text { Doorlooptijd } \\
\text { ziekenhui- } \\
\text { zen: }\end{array}$ & $\begin{array}{l}\text { Bijzonder- } \\
\text { heden: }\end{array}$ \\
\hline dialyse & 4 & 5 & 4 & 1 tot 3 jaar & \\
\hline $\begin{array}{l}\text { niertransplan- } \\
\text { tatie }\end{array}$ & 1 & 1 & 1 & n.v.t. & $\begin{array}{l}\text { was reeds } \\
\text { aanwezig }\end{array}$ \\
\hline neurochirurgie & $\begin{array}{l}1 \text { (hoofd- } \\
\text { centrum) }\end{array}$ & 6 & 6 & $\begin{array}{l}\text { hoofdcentrum } \\
\text { jaar } \\
\text { subcentra: sir } \\
\text { gehoord }\end{array}$ & $\begin{array}{l}\text { meer dan } 3 \\
\text { ds } 1985 \text { niets }\end{array}$ \\
\hline hartchirurgie & 1 & 1 & $\begin{array}{l}0 \\
1 \text { niet volledig }\end{array}$ & $\begin{array}{l}\text { meer dan } 2 \\
\text { jaar }\end{array}$ & \\
\hline $\begin{array}{l}\text { postnataal } \\
\text { chromosoom- } \\
\text { onderzoek en } \\
\text { prenatale dia- } \\
\text { gnostiek }\end{array}$ & 1 & 1 & 1 & 2 jaar & \\
\hline $\begin{array}{l}\text { hartcatheteri- } \\
\text { satie }\end{array}$ & - & 6 & $\begin{array}{l}1 \\
4 \text { niet volledig }\end{array}$ & $\begin{array}{l}3 \text { jaar of } \\
\text { meer }\end{array}$ & $\begin{array}{l}\text { geweigerde } \\
\text { aanvragen }\end{array}$ \\
\hline $\begin{array}{l}\text { intensieve } \\
\text { neonatologie }\end{array}$ & 1 & 4 & $\begin{array}{l}2 \\
2 \text { niet volledig }\end{array}$ & $\begin{array}{l}3 \text { jaar of } \\
\text { aanvragen } \\
\text { lopen nog }\end{array}$ & $\begin{array}{l}\text { onduidelijk } \\
\text { wat "intensief" } \\
\text { is }\end{array}$ \\
\hline $\begin{array}{l}\text { in vitro fertili- } \\
\text { satie }\end{array}$ & - & 2 & 2 & 1 of 5 jaar & \\
\hline Per 9 nov. 198 & buiten artike & & & & \\
\hline $\begin{array}{l}\text { computer to- } \\
\text { mografie }\end{array}$ & 3 & 4 & 4 & 1 tot 3 jaar & \\
\hline $\begin{array}{l}\text { nucleaire ge- } \\
\text { neeskunde }\end{array}$ & n.v.t. & 6 & 6 & \multicolumn{2}{|c|}{$\begin{array}{l}6 \text { aanvragen voor continue- } \\
\text { ring lopen sinds } 1985\end{array}$} \\
\hline
\end{tabular}

- = wordt niet vermeld in planningsbesluit

n.v.t. = planningsbesluit is er niet gekomen

De tijd die verstrijkt tussen het indienen van een vergunningaanvraag en de goedkeuring danwel weigering door de staatssecretaris loopt uiteen van één tot vijf jaar. Tussen het afkondigen van een Besluit en het inwerkingtreden van een planningsbesluit ligt minimaal drie jaar en maximaal dertien jaar (zie tabel 6.5). In de tussenliggende periode worden dan soms wel alvast vergunningaanvragen behandeld. Het is dus niet zonder meer mogelijk beide periodes bij elkaar op te tellen. Toch kan men stellen dat de totale doorlooptijd kan oplopen van vijf tot tien jaar of nog meer.

Naar aanleiding hiervan kan men de volgende vragen stellen. Wanneer de procedures zoveel tijd in beslag nemen, is de uitvoering van de maatregel dan nog wel de moeite waard? Gegevens zijn vaak al verouderd, omstandigheden veranderd en niet te vergeten technieken verbeterd. Bovendien is een voorziening waarschijnlijk allang in huis tegen de tijd dat, jaren later een vergunning wordt afgegeven. 
Verder blijkt de doorlooptijd duidelijk samen te hangen met het al dan niet voorhanden zijn van planningsbesluiten en met name door de trage besluitvorming op het ministerie (Algemene Rekenkamer, 1990-1991). Dit ligt voor de hand wanneer men de hiervoor geschetste discussie tussen het ministerie enerzijds en het College voor Ziekenhuisvoorzieningen anderzijds beziet.

Een duidelijke verklaring voor de verschillen tussen de behandeling van een aanvraag van eenzelfde soort voorziening door diverse instellingen, ontbreekt. Het heeft waarschijnlijk iets te maken met het al dan niet opgenomen zijn in het planningsbesluit van de aanwezigheid van die voorziening in een bepaalde instelling.

De verschillen die bestaan tussen de diverse snelheden waarmee anderssoortige voorzieningen onder artikel 18 worden gebracht, is wellicht te verklaren uit het feit dat artikel 18-voorzieningen zeer verschillend van aard zijn. Het gaat zowel om specialismen (neurochirurgie, hartchirurgie) als om faciliteiten (dialyse) als om functies (hartcatheterisatie) als om verrichtingen (postnataal chromosoomonderzoek) als ook om apparatuur (Computer Tomograaf). Bepaalde voorzieningen zijn goedkoper in de aanschaf of kosten minder extra investeringen of brengen minder ingrijpende veranderingen met zich mee. Wellicht is daaromtrent de besluitvorming sneller dan in geval van duurdere, veelomvattende voorzieningen.

Een gevolg van het feit dat vaak veel tijd verstrijkt tussen het indienen van een aanvraag en het antwoord dat men hierop ontvangt, is dat de instellingen in de gaten moeten blijven houden hoe het met de aanvragen gesteld is. De staven en directies van ziekenhuizen zijn hierdoor genoodzaakt brieven te schrijven, contacten te leggen en te lobbyen. Deze activiteiten leveren allemaal bestuurskosten op.

Er blijken ook andere manieren te zijn om bijzondere voorzieningen in huis te krijgen. Via sluiproutes, zoais aanschaf door een patiëntenvereniging en exploitatie door de instelling, doet de instelling de aanschaf alvast in de overtuiging dat eenmaal geplaatste apparatuur toch niet snel weer verwijderd zal behoeven te worden (Maarse, 1990; De Roo en Maarse, 1990; Maarse en Moen, 1991).

Al met al is het voor de ziekenhuizen misschien niet eens zo ongunstig dat de doorlooptijd zo lang is. Het vergroot namelijk de mogelijkheden om zelf naar een oplossing te zoeken. Bovendien is het voor de overheid moeilijk reeds aangeschafte apparatuur uit een ziekenhuis verwijderd te krijgen.

\section{§6.4 Evaluatie van de meting van de bestuurskosten van artikel 18}

In dit hoofdstuk wordt onderscheid gemaakt tussen de formele en de informele doorlooptijd. De informele doorlooptijd is langer dan de formele doorlooptijd. Men kan er immers van uit gaan dat al voordat een vergunningaanvraag wordt ingediend overleg heeft plaatsgehad. Het exacte beginpunt van dat overleg is echter onbekend. Daarom wordt hier de formele doorlooptijd gehanteerd.

Als mogelijke meetmethode is de doorlooptijd in zoverre geschikt dat de bepaling ervan eenvoudiger is en minder tijd kost dan bepaling van de direct bestede tijd. Bovendien biedt de doorlooptijd inzicht in het tempo van de besluitvorming.

Een validiteitsprobleem is het volgende. Het lijkt plausibel om aan te nemen dat een lange doorlooptijd hoge bestuurskosten impliceert. Dit hoeft echter niet zo te zijn, aangezien een aanvraag jarenlang in een la kan liggen, zonder dat er daad- 
werkelijk iets mee gebeurt. De doorlooptijd geeft dus een indicatie van de bestuurskosten, maar biedt geen exacte weergave.

Verder is het waarschijnlijk dat ook overleg over de aanschaf van apparatuur zou zijn gevoerd zonder het bestaan van artikel 18 .

De betrouwbaarheid van de meting van de doorlooptijd is groter dan de betrouwbaarheid van de meting van de directe uitvoering van een maatregel. Dit komt doordat de uitwerking van de hele artikel 18-procedure op papier vast ligt. Er is dus sprake van formele meetpunten. Toch ontbreekt een aantal gegevens en bestaan hier en daar nog onduidelijkheden. Met het oog op de betrouwbaarheid is gekozen voor een systematische beschrijving van de meting en de verzameling van de gegevens.

Generalisatieproblemen zijn niet direct aan de orde. De doorlooptijd van de totstandkoming van de planningsbesluiten is een landelijk gegeven. De doorlooptijd van de vergunningaanvragen is voor wat de provincie Limburg betreft volledig. Hierbij moet worden opgemerkt dat veel artikel 18-voorzieningen uitsluitend in het Academisch Ziekenhuis aanwezig zijn. Generalisatie voor heel Nederland is hier evenmin van toepassing, aangezien het slechts gaat om een indicatie van de doorlooptijd en niet om generalisatie naar alle vergunningaanvragen in het hele land.

\section{\$6.5 Samenvatting en conclusies}

In dit hoofdstuk is getracht de bestuurskosten te meten aan de hand van de doorlooptijd van antikel is van de Wet Ziekenhuisvoorzieningen.

De wettekst van de Wet Ziekenhuisvoorzieningen schrijft voor dat de staatssecretaris, na advies te hebben ingewonnen van de Gezondheidsraad of de Nationale Raad voor de Volksgezondheid, de colleges van Gedeputeerde Staten en het College voor Ziekenhuisvoorzieningen, een planningsbesluit over een bijzondere voorziening instelt. Dit planningsbesluit geeft aan aan hoeveel plaatsen, centra of apparaten van de betreffende voorziening behoefte bestaat. Hierna dienen instellingen aanvragen voor vergunningen voor de bijzondere voorziening die zij in huis wensen te krijgen. Vervolgens worden de vergunningaanvragen beoordeeld door het College voor Ziekenhuisvoorzieningen en de betreffende Gedeputeerde Staten. Aan de hand hiervan gaat de staatssecretaris over tot afgifte danwel weigering van de vergunning. Dit besluit wordt tenslotte bekend gemaakt in de Staatscourant.

In de praktijk verloopt de procedure aanzienlijk stroever. Op het moment dat de Wet Ziekenhuisvoorzieningen in werking trad, in 1979, waren nog slechts drie voorzieningen onder artikel 18 gebracht. Het zou tot 1984 duren voordat dit aantal werd uitgebreid tot tien. Intussen liep echter al een aanzienlijk aantal vergunningaanvragen. Deze aanvragen konden echter niet door het College voor Ziekenhuisvoorzieningen worden getoetst, zolang de planningsbesluiten nog niet van kracht waren. Toen de wachttijden uit de hand dreigden te lopen, heeft de staatssecretaris een soort "generaal pardon" afgekondigd. Vervolgens ontvingen alle ziekenhuizen zonder meer een continueringsvergunning.

De bestuurskosten van artikel 18 zijn bepaald aan de hand van de doorlooptijd. Dit is de tijd die verstrijkt tussen het begin en het einde van een bepaalde procedure.

De inventarisatie van de doorlooptijden heeft het volgende opgeleverd. De doorlooptijd van de planningsbesluiten bedroeg in de snelst verlopen procedure twee jaar en één maand en in de traagst verlopen procedure dertien jaar en twee 
maanden. De doorlooptijd van de vergunningaanvragen varieerde van één jaar tot viff jaar.

Men zou kanttekeningen kunnen maken tegen de doorlooptijd als indicatie van de hoogte van bestuurskosten. Bestuurskosten worden namelijk niet alleen gemaakt tijdens de formele uitvoering van de vergunningaanvragen. Tijdens de fase die hieraan voorafgaat, wanneer bijvoorbeeld specialisten beginnen met directieleden te benaderen omtrent een gewenste aanschaf, worden ook reeds bestuurskosten gemaakt. Deze tijd is echter in dit onderzoek niet meegenomen. Het is immers nauwelijks te achterhalen wanneer exact de eerste stappen zijn gezet in de richting van een vergunningaanvraag. Desalniettemin geeft de hier gehanteerde doorlooptijd wel enig inzicht in het tempo van de totstandkoming en in de bestuurskosten van artikel 18 . 



\section{BESTUURSKOSTEN IN BESTEDE TIJD}

\section{\$7.1 Inleiding}

In het vorige hoofdstuk is de doorlooptijd van een maatregel bepaald. Bij deze bepaling is enerzijds uitgegaan van landelijk afgekondigde maatregelen, zoals planningsbesluiten. Anderzijds is bij ziekenhuizen geïnventariseerd hoelang de doorlooptijd in de praktijk was.

Ook in dit hoofdstuk worden de bestuurskosten bepaald. Deze zijn gedefinieerd als de kosten van de bestuurlijke infrastructuur bij overheden en particulieren die het gevolg zijn van overheidsbesturing in de gezondheidszorg. In hoofdstuk 4 is verduidelijkt hoe deze kunnen worden gemeten. Eén van de mogelijke meetmethoden is de bepaling van de bestede tijd van een bepaalde maatregel. Onder de bestede tijd wordt daarbij verstaan de tijd die direct wordt besteed aan de uitvoering van een maatregel.

De bepaling van de bestede tijd heeft bijvoorbeeld plaatsgevonden in het onderzoek naar de uitvoeringskosten van welzijnsplanning door gemeenten. Hiertoe heeft het Onderzoeksbureau I.G.G. $(1985 ; 1986)$ aan alle betrokken ambtenaren en bestuurderen gevraagd een schatting te maken van de bestede tijd.

In dit hoofdstuk zal de tijd worden gemeten die direct betrokkenen hebben besteed aan de planning volgens artikel 4 van de Wet Ziekenhuisvoorzieningen. De meting vindt plaats bij iedereen die direct is betrokken bij de totstandkoming van het verpleeghuisplan in de provincie Limburg.

De opbouw van dit hoofdstuk is als volgt. In paragraaf 7.2 de planning volgens de Wet Ziekenhuisvoorzieningen beschreven. Verder wordt de te volgen procedure 
uiteengezet. In paragraaf 7.3 wordt eerst afgebakend welke activiteiten en betrokkenen wel en welke niet worden meegerekend. Hierna volgt de meting van de tijd die in de provincie Limburg is besteed aan de totstandkoming van het verpleeghuisplan. In paragraaf 7.4 wordt de meting van de bestuurskosten van een maatregel geëvalueerd. Tenslotte bevat paragraaf 7.5 de samenvatting en conclusies.

\section{§ 7.2.1 Achtergrond: artikel 4 Wet Ziekenhuisvoorzieningen}

De geschiedenis van de Wet Ziekenhuisvoorzieningen is als volgt. Sinds de Tweede Wereldoorlog werd de bouw van gezondheidszorginstellingen geregeld via de Wederopbouwwet. Toen deze werd ingetrokken moest daarvoor een andere regeling in de plaats komen. Dit werd via het wetsvoorstel Ziekenhuisbouw de Wet Ziekenhuisvoorzieningen. De oorspronkelijke Wet Ziekenhuisvoorzieningen uit 1971 berustte op een bouwverbod. Het was verboden om zonder vergunning van de minister een ziekenhuisvoorziening te bouwen, te verbouwen, uit te breiden of in gebruik te nemen. Men zou alleen in aanmerking komen voor een vergunning, wanneer de bouwaanvraag paste in het landelijke plan voor ziekenhuisvoorzieningen (Roscam Abbing, 1983). Door middel van de Wet Ziekenhuisvoorzieningen beoogde de regering een doelmatige en evenwichtige spreiding van voorzieningen tot stand te brengen en de kosten van de gezondheidszorg te beheersen. Behalve de bouw en de planning regelde de oorspronkelijke Wet Ziekenhuisvoorzieningen de instelling van het College voor Ziekenhuisvoorzieningen als adviesorgaan voor de regering.

Eén landelijk plan voor alle categorieën van ziekenhuisvoorzieningen bleek te star en de opstelling ervan te ingewikkeld en te tijdrovend. Het plan zou alweer achterhaald zijn, voordat het was vastgesteld (Wet Ziekenhuisvoorzieningen, 1986). Bovendien bleek een volgens de opgelegde normen een overschot aan bedden te bestaan. Dit overschot werd door de instellingen niet vrijwillig weggewerkt, hetgeen echter wel de bedoeling was (Roscam Abbing, 1986). Om deze reden werd de Wet Ziekenhuisvoorzieningen gewijzigd en trad in 1979 integraal in werking.

Nog later had de Wet Ziekenhuisvoorzieningen moeten opgaan in de Wet Voorzieningen Gezondheidszorg. Het Financieel Overzicht had de financiële begrenzing moeten vormen. Ook dit zou worden vastgelegd in de Wet Voorzieningen Gezondheidszorg. De Wet Voorzieningen Gezondheidszorg is echter nooit integraal ingevoerd en intussen zelfs alweer ingetrokken.

De positie van de Wet Ziekenhuisvoorzieningen in de loop der jaren weergegeven in schema 7.1. 
Schema 7.1 De positie van de Wet Ziekenhuisvoorzieningen door de jaren heen

$\begin{array}{lll}\text { Capaciteit } & \text { X Prijs } & =\text { Kosten } \\ \text { Wederopbouwwet (1950) } & \begin{array}{l}\text { Prijsopdrijvings- en Ham- } \\ \text { sterwet (1939) }\end{array} & \begin{array}{l}\text { Bouwvolume gezond- } \\ \text { heidszorg }\end{array}\end{array}$

Wet Ziekenhuisvoorzie- Wet Ziekenhuistarieven ningen (1979)

Wet Voorzieningen Ge(1965)

Bouwplafond ziekenhuisvoorzieningen (1975)

Wet Tarieven GezondFinancieel Overzicht Gezondheidszorg (1982) heidszorg (1982) zondheidszorg en Maatschappelijke Dienstverlening (1984)

Bron: J.M. Boot en M.H.J.M. Knapen

De Nederlandse gezondheidszorg

Utrecht, 1986

De planning volgens de Wet Ziekenhuisvoorzieningen kent de nodige raakviakken met andere gezondheidszorgregelingen.

Allereerst heeft de planning ex Wet Ziekenhuisvoorzieningen een duidelijke relatie met artikel 22 van de Grondwet, waarin staat dat "de overheid maatregelen treft ter bevordering van de volksgezondheid" (Grondwet, 1987). Krachtens dit artikel heeft de overheid een inspanningsverplichting tegenover de burgers om te zorgen voor de bereikbaarheid en toegankelijkheid van gezondheidszorgvoorzieningen. Dit recht van de burgers komt in het geding wanneer bijvoorbeeld niet genoeg bedden zijn gepland in verhouding tot het aanbod van patiënten die over een indicatie beschikken voor opname in een verpleeghuis (Roscam Abbing, 1990).

Het Financieel Overzicht geldt als leidraad voor de planning. In het Financieel Overzicht zijn de maximaal toegestane functie-eenheden voor de gehele gezondheidszorg weergegeven. Hierop worden de financiële kaders voor de regio's gebaseerd.

Ook de wetten die de financiële toegankelijkheid regelen, namelijk de Ziekenfondswet en de Algemene Wet Bijzondere Ziektekosten, kennen een relatie met de Wet Ziekenhuisvoorzieningen. Een instelling die functioneert in het kader van de Wet Ziekenhuisvoorzieningen moet, om in aanmerking te komen voor een overeenkomst en dus financiering krachtens de Ziekenfondswet en de Algemene Wet Bijzondere Ziektekosten, erkend zijn volgens deze beide wetten (artikel 8). Verder leidt een vergunning voor een bijzondere voorziening volgens de Wet Ziekenhuisvoorzieningen niet automatisch tot financiering (Leenen en Roscam Abbing, 1986).

Anderzijds stelt artikel $8 \mathrm{c}$ van de Ziekenfondswet en de Algemene Wet Bijzondere Ziektekosten onder meer dat een erkenning wordt geweigerd, indien een instelling niet voldoet aan de eisen die de Wet Ziekenhuisvoorzieningen stelt. Echter, op grond van artikel 47 is een ziekenfonds verplicht ook specialisten, die deels binnen een bepaalde instelling en deels daarbuiten werkzaam zijn, te contracteren. Zolang artikel 47 niet is aangepast, doorkruist de Ziekenfondswet de instroombeperking die wordt beoogd met het Financieel Overzicht (Foscam Abbing, 1984A).

Sinds 1976 is in de erkenning volgens de Ziekenfondswet en de Algemene Wet Bijzondere Ziektekosten tevens het limitatieve aantal en het soort functies, die de betreffende instelling mag uitoefenen, opgenomen (Roscam Abbing, 1984A). Deze erkenning vormde de voorloper van de planning krachtens de Wet Ziekenhuisvoorzieningen (Roscam Abbing, 1984B).

Tenslotte speelt de Wet Ziekenhuisvoorzieningen een rol bij de verdeling van de ziekenhuisbudgetten op grond van de Wet Tarieven Gezondheidszorg. In de 
huidige budgetsystematiek is de hoogte van het budget, dat een instelling krijgt toegewezen, afhankelijk van een aantal factoren. Onder meer het aantal erkende bedden en het aantal en het soort functie-eenheden ofwel specialistenplaatsen is bepalend voor de hoogte van het budget. Deze twee factoren worden bepaald aan de hand van de erkenning die een instelling bezit op basis van de Wet Ziekenhuisvoorzieningen. Bovendien levert de aanwezigheid van een artikel 18-voorziening een ziekenhuis een groter budget op (Centraal Orgaan Tarieven Gezondheidszorg, 1989).

Schema 7.2 geeft de raakvlakken van de planning volgens de Wet Ziekenhuisvoorzieningen met andere regelingen in de gezondheidszorg weer.

Schema 7.2 De raakvlakken van artikel 4 Wet Ziekenhuisvoorzieningen met andere regelingen

\begin{tabular}{ll}
\hline Regelingen: & Raakvlakken: \\
\hline Financieel Overzicht & leidraad voor de planning \\
artikel 8 Ziekenfondswet & instellingen behoeven erkenning \\
artikel 47 Ziekenfondswet & $\begin{array}{l}\text { contracteerplicht voor ziekenfondsen } \\
\text { van specialisten die (gedeeltelijk) in } \\
\text { een instelling werkzaam zijn }\end{array}$ \\
artikel 22 Grondwet & $\begin{array}{l}\text { bereikbaarheid en toegankelijkheid van } \\
\text { gezondheidszorgvoorzieningen gega- } \\
\text { randeerd } \\
\text { hudgettering volgens Wet Tarieven } \\
\text { hezondheidszorg }\end{array}$ \\
& $\begin{array}{l}\text { kelijk van de krachtens de Wet Zieken- } \\
\text { huisvoorzieningen erkende bedden en } \\
\text { functie-eenheden }\end{array}$ \\
\hline
\end{tabular}

De kritiek op de werking van de planning krachtens de Wet Ziekenhuisvoorzieningen is aanzienlijk. De financiële kaders waarop de planning zou moeten worden gobaseerd, ontbreken nog steeds (Krol en Passchier, 1986). De planning is te gedetailleerd (Krol en Passchier, 1986; Algemene Rekenkamer, 1986-1987 en 19891990; College voor Ziekenhuisvoorzieningen, 1987; Commissie-Dekker, 1987) en zou beperkt moeten blijven tot grootschalige instellingen (Commissie-Dekker, 1987). Er is een betere afstemming nodig tussen de planning en andere beleidsmaatregelen.

Deze kritiek is niet verwonderlijk wanneer men bedenkt dat Nederland, krachtens de Wet Ziekenhuisvoorzieningen, is onderverdeeld in 27 gezondheidsregio's. Voor al deze regio's dienen de betrokken provincies één ziekenhuisplan, één psychiatrieplan en één verpleeghuisplan te produceren. Voor de sector zwakzinnigenzorg moet er één landelijk plan komen. In totaal zijn dit 81 regio-plannen. Sedert de eerste aanwijzingen, die in januari 1983 zijn afgegeven, zijn per 1 januari 1989 vier ziekenhuisplannen, vier psychiatrieplannen en twaalf verpleeghuisplannen vastgesteld (College voor Ziekenhuisvoorzieningen, 1989). Aan de overige plannen wordt al sinds 1983 gewerkt, voorzover de betreffende aanwijzingen door de staatssecretaris tenminste al zijn afgegeven. In tabel 7.1 is de stand van zaken per 1 januari 1989 weergegeven. 
Tabel 7.1 Aantallen aanwijzingen, ontwerpplannen, adviesaanvragen, adviezen van vastgestelde plannen per sector van voorzieningen (per 1 jan. 1989)

\begin{tabular}{l|rrrrr}
\hline & $\begin{array}{l}\text { aanwij- } \\
\text { zingen }\end{array}$ & $\begin{array}{l}\text { ontwerp- } \\
\text { plannen }\end{array}$ & $\begin{array}{l}\text { adviesaan- } \\
\text { vragen }\end{array}$ & adviezen & $\begin{array}{l}\text { vastge- } \\
\text { stelde } \\
\text { plannen }\end{array}$ \\
\hline ziekenhuizen & 26 & 2 & 1 & 1 & $1^{*}$ \\
verpleeghuizen & 20 & 10 & 9 & 9 & 6 \\
psychiatrie & 24 & 12 & 12 & 8 & 4 \\
\hline \hline Totaal: & 70 & 24 & 22 & 18 & 11 \\
\hline
\end{tabular}

* = 12, volgens het College voor Ziekenhuisvoorzieningen (Jaarverslag 1988, Utrecht 1989)

Bron: Algemene Rekenkamer

Planning en bouw van ziekenhuisvoorzieningen

Tweede Kamer 1989-1990, 21674 , nrs.1-2, P.11

Uit tabel 7.1 blijkt dat de provincies een enorme planningsactiviteit moeten leveren om al deze regio- en sectorplannen op te stellen.

\section{§ 7.2.2 De planprocedure conform de Wet Ziekenhuisvoorzieningen}

Formeel start de procedure door de aanwijzingen die de staatssecretaris aan de azzonderlijke provinciebesturen per regio en voor iedere vorm van voorziening verstrekt. Door middel van een aanwijzing geeft de staatssecretaris aan het bestuur van een bepaalde provincie de opdracht een ontwerp-plan te maken voor een bepaalde hoofdgroep van voorzieningen. Deze hoofdgroepen betreffen ziekenhuizen, verpleeghuizen en psychiatrische ziekenhuizen. Met het geven van de aanwijzing start de staatssecretaris de formele procedure voor het ontwerpen van een plan. In de praktijk begint de planprocedure bij het ambtelijke vooroverleg tussen het departement, de betrokken provincie(s) en het College voor Ziekenhuisvoorzieningen.

Behalve een planopdracht bevat een aanwijzing een aantal bepalingen met betrekking tot:

- de hoofdgroep waar het om gaat, zoals verpleeghuizen;

- de gezondheidsregio waarop het plan betrekking heeft, bijvoorbeeld de regio's Noord- en Zuid-Limburg;

- de termijn waarbinnen een ontwerp-plan dient te worden voltooid. Doorgaans is deze termijn 18 maanden met een mogelijke verlenging tot 24 maanden;

- informatie die meer is toegesneden op de specifieke omstandigheden in de desbetreffende regio. Deze informatie kan betrekking hebben op de aanwezigheid van boven-regionale voorzieningen, waarmee rekening moet worden gehouden of van grensoverschrijdende patiëntenstromen;

- de financiële aspecten van het ontwerpen van een plan. De staatssecretaris geeft aan binnen welke financiële begrenzingen het ontwerpplan dient te blijven (Wet Ziekenhuisvoorzieningen, 1986). 
In de praktijk is gebleken dat deze financiële kaders meestal ontbreken. In de derde gewijzigde versie van de richtlijnen is dit voorschrift dan ook afgezwakt. De formulering luidt nu als volgt: "Tenslotte kunnen eventueel afspraken worden opgenomen die gemaakt zijn over de berekening van een financieel kader na afronding van de inventarisatie" (Wet Ziekenhuisvoorzieningen, 1988, p.598).

$\mathrm{Na}$ het verschijnen van de richtlijnen en de aanwijzingen start met de volgende stap de eigenlijke planprocedure. Deze verloopt formeel als volgt: nadat Provinciale Staten de aanwijzing van de staatssecretaris hebben ontvangen, stellen Gedeputeerde Staten aan de hand van de richtijnen een voorontwerp van een plan op. Hierin dient "de behoefte aan de in de aanwijzing aangegeven ziekenhuisvoorzieningen in het aangegeven gebied" te zijn neergelegd en omschreven te worden "welke aanvullingen of veranderingen in het reeds aanwezige bestel naar hun oordeel nodig zijn om op een doelmatige wijze in die behoefte te voorzien", aldus artikel 4 lid 2 van de Wet Ziekenhuisvoorzieningen (Wet Ziekenhuisvoorzieningen, 1986, p.27). Indien nodig, bijvoorbeeld bij grensoverschrijdende voorzieningen, gebeurt dit in overleg met naburige provincies.

Het voorontwerp dient 30 dagen ter inzage te liggen bij de provinciale griffie. Deze tervisielegging moet bekend gemaakt worden in de Staatscourant en in regionale bladen. Belanghebbenden kunnen dan binnen twee maanden bezwaren indienen bij Provinciale Staten. Hierna krijgen de indieners de gelegenheid hun bezwaren toe te lichten op een hoorzitting.

Tenslotte stellen Provinciale Staten het door Gedeputeerde Staten voorgestelde voorontwerpplan, al dan niet gewijzigd, vast.

Het ontwerp-plan wordt, met een verslag van de bezwaren, de hoorzitting en de antwoorden hierop, toegestuurd aan de staatssecretaris en aan het College voor Ziekenhuisvoorzieningen, dat de staatssecretaris hieromtrent adviseent. Het ontwerp-plan wordt getoetst aan de richtlijnen en de aanwijzing. Na de ontvangst van dat advies stelt de staatssecretaris het plan vast (conform artikel 5).

Schema 7.3 geeft het formele planproces weer.

Schema 7.3 Planprocedure volgens de wettekst van de Wet Ziekenhuisvoorzieningen

\begin{tabular}{lll}
\hline Fasen: & Activiteiten: & Actoren: \\
\hline 1 & aanwijzing + richtlinen & staatssecretaris \\
2 & voorontwerp & provincie(s) \\
3 & inspraakronde & bezwaarden \\
4 & ontwerpplan & provincie \\
5 & advies & College voor Ziekenhuisvoorzieningen \\
6 & vaststelling plan & staatssecretaris \\
\hline
\end{tabular}

Bovenstaand is de procedure omschreven die moet worden gevolgd bij het opstellen van een plan ex Wet Ziekenhuisvoorzieningen. Omtrent de procedure in de fase waarin de provincie het voorontwerp moet opstellen wordt de provincie vrijgelaten (Algemene Rekenkamer, 1989-1990). In de tweede druk van de toelichting bij de richtlijnen staat wel dat "het aanbeveling verdient dat de inrichtingen reeds in een vroeg stadium hun inbreng kunnen leveren bij het ontwerpen van een plan. Verwacht mag worden dat de bereidheid tot medewerking aan de realisering 
van het ontwerpplan zal toenemen wanneer de desbetreffende inrichting bij de voorbereiding daarvan zoveel mogelijk betrokken is geweest" (Krol en Passchier, 1986, p.62). Het staat de provincies vrij de procedure in de ontwerpfase nader in te vullen. Het blijkt dan ook dat de provincies dit op zeer verschillende wijzen doen. Van de zes regio's, waarvan Krol en Passchier (1986) het planproces hebben gevolgd, is geen enkele gelijk aan enige andere.

\section{§ 7.2.3 De planprocedure volgens de Wet Ziekenhuisvoorzieningen en de Wet Voorzieningen Gezondheidszorg in de provincie Limburg}

In december 1983 werd aan de provincie Limburg de aanwijzing verstrekt voor de opstelling van een verpleeghuisplan. Op dat moment was de provincie Limburg bezig met de (experimentele) integrale invoering van de Wet Voorzieningen Gezondheidszorg. Oorspronkelijk was het de bedoeling dat de Wet Ziekenhuisvoorzieningen te zijner tijd zou opgaan in de Wet Voorzieningen Gezondheidszorg. Hierop anticiperend heeft de provincie Limburg de planprocedure aanvankelijk gebaseerd op zowel de Wet Ziekenhuisvoorzieningen als de Wet Voorzieningen Gezondheidszorg. Dit had de volgende consequenties. In de eerste plaats heeft dit ertoe geleid dat de instellingen door middel van de Samenwerkingsverbanden, de gemeenten via de Streekgewesten en de ziekenfondsen bij de planning zijn betrokken. Dit is een uitvloeisel van het feit dat de Wet Voorzieningen Gezondheidszorg een zo groot mogelijke betrokkenheid bepleit voor het veld en de gebruikers. Overigens bleek het veld ook in regio's waar men niet met Wet Voorzieningen Gezondheidszorg experimenteerde te worden betrokken bij de totstandkoming van het plan (Krol en Passchier, 1986; College voor Ziekenhuisvoorzieningen, 1987).

In de tweede plaats betekende afstemming van de planprocedure van de Wet Ziekenhuisvoorzieningen op die van de Wet Voorzieningen Gezondheidszorg dat een plan dat normaliter uitsluitend de verpleeghuissector zou behelzen zich nu zou uitstrekken over de gehele langerdurende gezondheidszorg. Ook dit was een gevolg van de Wet Voorzieningen Gezondheidszorg, die zich voor wat de planning betreft niet beperkte tot sectoren van zorg (bijvoorbeeld de verpleeghuissector), maar de gehele eerste- en tweedelijn beoogde te omvatten.

Dit alles heeft ertoe geleid dat Provinciale Staten de volgende procedure hebben vastgesteld:

1. Eerst diende een planmatige, bouwkundige en financieel-economische inventarisatie plaats te vinden. Zowel de Provinciale Raad voor de Volksgezondheid als andere instanties kunnen deze inventarisatie uitvoeren, met de provincie als coördinator.

2. Vervolgens stellen Gedeputeerde Staten een ontwerp-beleidsvisie op, die door de Provinciale Raad, de Samenwerkingsverbanden van instellingen, de ziekenfondsen (in een "consultatief overleg") en de gemeenten (die worden "gehoord") van advies wordt voorzien. Hierna stellen Provinciale Staten de ontwerp-beleidsvisie vast.

3. Dan krijgt de Provinciale Raad de opdracht tot het voorontwerpen van planonderdelen die betrekking hebben op de verdeling en de spreiding van voorzieningen. Hiertoe dienden plangroepen ingesteld te worden, die functioneren onder de verantwoordelijkheid van de Raad. Voordat de Raad het voorontwerp vaststelt, moet ("pré-")advies worden ingewonnen van de samenwerkingsverbanden van instellingen. 
4. Daarna plegen Gedeputeerde Staten "consultatief overleg" met de ziekenfondsen over de financiële consequenties van het voorontwerpplan, waarna Gedeputeerde Staten het ontwerp-plan vaststellen. Dit wordt vervolgens ter visie gelegd met de gebruikelijke openbaarmakingen. Daarbij wordt gewezen op de mogelijkheid tot het indienen van bezwaren. Deze bezwaarschriften behandelt de Commissie voor Algemene Zaken uit Provinciale Staten. Provinciale Staten beslissen tenslotte over de ingediende bezwaren en stellen het ontwerp vast.

Bovenstaande procedure is weergegeven in schema 7.4 .

Schema 7.4 Planprocedure volgens de Wet Ziekenhuisvoorzieningen en de Wet Voorzieningen Gezondheidszorg in de provincie Limburg

\begin{tabular}{|c|c|c|}
\hline Fase: & Activiteiten: & Actoren: \\
\hline 1 & inventarisatie & $\begin{array}{l}\text { Provinciale Raad voor de Volks- } \\
\text { gezondheid }\end{array}$ \\
\hline 2 & $\begin{array}{l}\text { opstellen ontwerp-beleidsvisie } \\
\text { advies ontwerp-beleidsvisie } \\
\text { consultatie ontwerp-beleidsvisie } \\
\text { gehoord ontwerp-beleidsvisie } \\
\text { vaststelling }\end{array}$ & $\begin{array}{l}\text { Gedeputeerde Staten } \\
\text { Provinciale Raad voor de Volks- } \\
\text { gezondheid } \\
\text { samenwerkingsverbanden } \\
\text { ziekenfondsen } \\
\text { gemeenten } \\
\text { Provinciale Staten }\end{array}$ \\
\hline 3 & $\begin{array}{l}\text { opstellen voorontwerp } \\
\text { pré-advies voorontwerp } \\
\text { consultatief overleg voorontwerp }\end{array}$ & $\begin{array}{l}\text { Provinciale Raad voor de Volks- } \\
\text { gezondheid } \\
\text { plangroepen } \\
\text { samenwerkingsverbanden } \\
\text { ziekenfondsen }\end{array}$ \\
\hline 4 & $\begin{array}{l}\text { vaststelling ontwerp-plan } \\
\text { tervisielegging ontwerp-plan } \\
\text { indienen bezwaarschriften } \\
\text { behandeling bezwaarschriften } \\
\text { beslissing bezwaren } \\
\text { vaststelling ontwerp-plan }\end{array}$ & $\begin{array}{l}\text { Gedeputeerde Staten } \\
\text { belanghebbenden } \\
\text { Provinciale Staten } \\
\text { Provinciale Staten } \\
\text { Provinciale Staten }\end{array}$ \\
\hline
\end{tabular}

Zoals opgemerkt was de in Limburg gevolgde procedure geënt op de planprocedure volgens de Wet Voorzieningen Gezondheidszorg. De consequenties hiervan waren een uitgebreide inspraakronde en een breed bereik van het plan. Dit lijkt een uitzonderlijke situatie. De situatie is echter analoog aan die in de regio's Zeeland, Utrecht en West-Brabant, waar eveneens verpleeghuisplannen zijn opgesteld. Vergelijkt men de in Limburg gevolgde procedure met de in deze drie regio's gevolgde, dan valt op dat met name in Utrecht en West-Brabant de procedure minstens zo uitgebreid is geweest. Ook hier zijn bijvoorbeeld aparte plancommissies in het leven geroepen en worden tussentijds adviezen ingewonnen bij externe instanties (Krol en Passchier, 1986).

Toen in 1986 de Commissie-Dekker werd geïnstalleerd, beval zij in haar rapport "Bereidheid tot verandering" (maart 1987) onder meer "een sterk vereenvoudigde WZV inzake bouw en spreiding van grootschalige intramurale instellingen en landelijke voorzieningen, waaronder die voor bejaarden" (p.22) aan. De Commissie was van mening dat kon worden volstaan met "een instrument tot beheersing van 
spreiding en capaciteit van grote infrastructurele functies, alsmede met een instrument om de totstandkoming van een beperkt aantal landelijke voorzieningen zonodig te bevorderen" (p.94). Hiertoe zou een relatief eenvoudig wettelijk instrumentarium toereikend zijn. De Commissie vond dat de planning beperkt moest blijven tot het vaststellen van maxima waarbinnen de capaciteit van grote voorzieningen dient te blijven. De uitvoering zou worden gefiatteerd door middel van verklaringen van geen bezwaar. Wie deze afgeslankte planning ter hand zou moeten nemen, liet de Commissie in het midden. Verder beval de Commissie aan de Wet Voorzieningen Gezondheidszorg in te trekken.

Het kabinet nam de voorstellen van de Commissie-Dekker voor wat de grootschalige intramurale voorzieningen (algemene en psychiatrische ziekenhuizen, inrichtingen voor geestelijk gehandicapten, verpleeghuizen en bejaardenhuizen) betreft over. De Wet Ziekenhuisvoorzieningen zou voor het regelen van het toezicht hierop worden aangepast. Daarnaast zou bezien worden of alle voorzieningen die nu onder het regime van de Wet Ziekenhuisvoorzieningen valten ook in de toekomst onder deze wet moesten blijven ressorteren.

De uitvoering van de Wet Ziekenhuisvoorzieningen zal zoveel mogelijk door de provincies plaatshebben. De rijksoverheid zal hiertoe de financiële kaders en eventuele landelijke planningsnormen aangeven, waarbinnen die uitvoering gestalte dient te krijgen. Het is echter niet langer verplicht dat de provincies te allen tijde een geldend plan hebben, waaruit het aanbod en de capaciteit blijkt. Het is verder de bedoeling dat de aanbieders van zorg en de financiers (of "zorgverzekeraars") een grotere inbreng krijgen bij de planning. Zij moeten door middel van onderhandelingen tot afspraken komen, zonder inmenging van de overheid. Bovendien komt in de nota "Verandering verzekerd" naar voren dat de Wet Voorzieningen Gezondheidszorg niet verder ingevoerd zal worden en op termijn zal worden ingetrokken. In maart 1988 gebeurde dit daadwerkelijk.

\section{$\S 7.2 .4$ De invulling van de planprocedure door de provincie Limburg}

Het gevolg van deze politieke ontwikkeling was enerzijds dat de wettelijke basis ontbrak voor de planning van de gehele langerdurende gezondheidszorg, aangezien de Wet Voorzieningen Gezondheidszorg werd ingetrokken; anderzijds diende het provinciaal plan, zoals hierboven reeds beschreven, globaler te zijn en meer over te laten aan de onderhandelingen tussen de aanbieders van zorg en de zorgverzekeraars.

Over de gewijzigde rol van de provincies in het kader van de gezondheidszorgplanning bestond begin 1988 bij de provincie Limburg nog onduidelijkheid. Bij wet of besluit was nog niets geregeld. Blijkens het ontwerpplan van de provincie Limburg kon alleen uit een schrijven van de staatssecretaris aan het interprovinciaal Overleg van Welzijn, Volksgezondheid en Cultuur (van 11 nov. 1988) hierover iets worden afgeleid. De taak van de provincie zou dan namelijk bestaan uit het "uitvoeren van een gedereguleerde en vereenvoudigde Wet Ziekenhuisvoorzieningen alsmede uit het ontwikkelen van hoofdlinen voor de zorgstruktuur" (Provincie Limburg, Bureau Volksgezondheid, 1989, p.1).

Onder invloed van de hierboven beschreven ontwikkelingen en in afwachting van wetgeving waarin de nieuwe rol voor de provincies zou worden vastgelegd, heeft het bureau Volksgezondheid van de provincie in overleg met Gedeputeerde Staten besloten om de reeds in gang gezette methode van planning te verlaten. Dit 
ondanks het feit dat de op dat moment reeds een concept-voorontwerpplan gereed was (zie paragraaf 7.2.2). Deze methode behelsde het gedetailleerd beschrijven van geplande voorzieningen, aangevuld met een overzicht van de financiële consequenties. De nieuwe methode hield in dat volstaan zou worden met een globale omschrijving van het gewenste voorzieningenniveau.

Aangezien, zoals gezegd, een omschrijving van hetgeen in een plan diende te staan ontbrak, heeft de provincie voor het vervolg van de totstandbrenging van de verpleeghuisplannen besloten de volgende weg te bewandelen. Het Bureau Volksgezondheid heeft een algemene beleidsvisie opgesteld. Aan deze beleidsvisie is een overzicht toegevoegd, waarin is aangegeven welke totale capaciteit men wenselijk achtte. Op grond hiervan is een kader geschapen waaraan de provincie aanvragen kan toetsen. Overigens heeft men bij de opstelling hiervan, waar mogelijk, rekening gehouden met de reeds in de concept-voorontwerpplannen naar voren gebrachte aanbevelingen.

De randvoorwaarden voor dit kader vormden de planningsrichtlijnen ex Wet Ziekenhuisvoorzieningen voor de verpleeghuissector. Deze richtlijnen bevatten immers de behoeftenormen voor verpleeghuisbedden en dagbehandelingsplaatsen. Verder heeft de provincie rekening gehouden met het financiële kader, dat de staatssecretaris in 1987 heeft verstrekt bij de aanwijzing.

Hierna was de procedure als volgt:

- de aanbevelingen van het inmiddels reeds gereed zijnde concept-voorontwerpplan heeft men, voor zover deze te gebruiken waren, meegenomen;

- volgens de hierboven beschreven nieuwe methode heeft de griffie opnieuw een concept-voorontwerpplan opgesteld;

- de Provinciale Raad voor de Volksgezondheid en de Algemene Samenwerkingsverbanden Gezondheidszorg zijn verzocht advies te geven;

- de financiers zijn "gehoord" in verband met de door hen reeds gemaakte produktie-afspraken.

Vervolgens startte de inspraakprocedure krachtens de Wet Ziekenhuisvoorzieningen, die ongewijzigd is gebleven (30 dagen tervisielegging, twee maanden voor het indienen van bezwaarschriften); waarna vaststelling door Provinciale Staten volgde.

De aangepaste planprocedure is weergegeven in schema 7.5.

Schema 7.5 De aangepaste planprocedure na "Dekker"

\begin{tabular}{lll}
\hline Fasen: & Activiteiten: & Actoren: \\
\hline 1 & $\begin{array}{l}\text { richtlijnen } \\
\text { behoeftenormen } \\
\text { financieel kader }\end{array}$ & staatssecretaris \\
2 & algemene beleidsvisie & provinciale griffie \\
3 & voorontwerp & $\begin{array}{l}\text { provinciale griffie } \\
4\end{array}$ \\
& advisering & $\begin{array}{l}\text { Provinciale Raad voor de Volksgezondheid } \\
\text { samenwerkingsverbanden } \\
\text { financiers }\end{array}$ \\
5 & inspraakprocedure & bezwaarden \\
\hline
\end{tabular}


Vergelijkt men deze procedure met die van "vò̀r Dekker", dan valt op dat de inbreng van de Provinciale Raad, de Samenwerkingsverbanden en de financiers naar een later tijdstip is verschoven. "Vòdr Dekker" mochten zij participeren in of zelfs het initiatief nemen tot de planopstelling. In de procedure die de provincie nà Dekker heeft vastgesteld, vond advisering pas plaats nadat het voorontwerp door het bureau Volksgezondheid was opgesteld. Dit is niet in overeenstemming met de voorstellen van het rijk in de nota "Verandering verzekerd" (1987-1988) (zie paragraaf 7.2.3).

\section{\$ 7.3 De meting van de bestuurskosten van artikel 4}

Hiervoor zijn de procedures beschreven die volgens de wettekst en volgens de regeringsvoorstellen gebaseerd op de Commissie-Dekker dienen te worden gevolgd. Hierna komt de in de praktijk gevolgde procedure aan de orde. Daarbij is geinventariseerd hoeveel tijd het uitvoeren van artikel 4 van de Wet Ziekenhuisvoorzieningen heeft gekost.

De bestuurskosten zijn in hoofdstuk 2 gedefinieerd als de kosten van de bestuuriijke infrastructuur bij overheden en particulieren die het gevolg zijn van overheidsbesturing. Toegepast op artikel 4 van de Wet Ziekenhuisvoorzieningen bestaan de bestuurskosten die overheden maken uit kosten van de totstandkoming van artikel 4 en van de uitvoering hiervan. Tot de totstandkoming van regels kan men rekenen de afgifte van planningsaanwijzingen. Tot de uitvoering van regels kan men rekenen het beoordelen van ontwerpplannen. Bij instellingen maken de kosten van de beinvloeding bij de opstelling van de plannen deel uit van de bestuurskosten.

Een extra indicatie van de bestuurskosten is de bestuurlijke drukte. Om een indruk te geven van de bestuurlijke drukte die gepaard gaat met de uitvoering van artikel 4 is in schema 7.6 weergegeven wie betrokken zijn geweest bij die uitvoering. 
Schema 7.6 instanties die zijn betrokken bij de uitvoering van artikel 4

\begin{tabular}{l|l}
\hline Buiten de provincie Limburg: & In de provincie Limburg: \\
\hline staatssecretaris & bureau Volksgezondheid van de pro- \\
departement van Welzijn, Volksge- & vinciale griffie \\
zondheid en Cultuur & Gedeputeerde Staten \\
College voor Ziekenhuisvoorzieningen & Provinciale Staten \\
Interprovinciaal Overleg Welzijn, Volks- & bureau van de Provinciale Raad voor \\
gezondheid en Cultuur & de Volksgezondheid \\
provincie Noord-Brabant & Dagelijks Bestuur van de Provinciale \\
& Raad voor de Volksgezondheid \\
& Algemeen Bestuur van de Provinciale \\
& Raad voor de Volksgezondheid \\
& samenwerkingsverbanden van instel- \\
& lingen \\
& streekgewesten van gemeenten \\
& ziekenfondsen \\
& plangroep, bestaande uit vertegenwoo- \\
& rdigers van: \\
& - Provinciale Raad \\
& - provinciale griffie \\
& - instellingen \\
& - eerstelijn \\
& - ziekenfondsen \\
& - inspectie \\
\hline
\end{tabular}

Voordat meting kan plaatsvinden moet eerst een aantal keuzen worden gemaakt. Deze keuzen hebben betrekking op het volgende. Duidelijk moet ten eerste zijn welke tijdstippen het beginpunt en het eindpunt van de meting vormen. Als beginpunt is gekozen de formele start van de procedure. Op het moment waarop de staatssecretaris aan Provinciale Staten van Limburg de aanwijzing verstrekte om een verpleeghuisplan op te stellen voor Noord- en Zuid-Limburg (december 1983) is de procedure in gang gezet. In verband met het gelijktijdig van kracht zijn van de Wet Voorzieningen Gezondheidszorg was men al bezig met het opstellen van zogenaamde bestuursorganisatorische maatregelen. Deze maatregelen moesten de bestuurlijke structuur voor de uitvoering van de Wet Voorzieningen Gezondheidszorg regelen. Aangezien de tijd die hiermee gemoeid was een direct gevolg was van de experimentele invoering van de Wet Voorzieningen Gezondheidszorg en niet van de uitvoering van de Wet Ziekenhuisvoorzieningen is deze tijd buiten beschouwing gelaten. Dit geldt ook voor de afgifte van de planningsaanwijzing.

Het eindpunt van de meting is de vaststelling van het ontwerpplan door Gedeputeerde Staten. Hierna volgt nog de inspraakronde en de politieke besluitvorming door Provinciale Staten. De gehele afronding zou echter nog zo lang duren (het werd uiteindelijk februari 1991 voordat het verpleeghuisplan door de staatssecretaris werd goedgekeurd) dat deze fase buiten beschouwing is gelaten.

Ten tweede moet duidelijk zijn welke uitvoerenden wel en welke niet bij de meting betrokken zijn. Hiervoor geldt dat iedereen, die direct bij de totstandkoming van het plan betrokken was, benaderd is. Indirecte medewerkers, zoals administratieve, archief-, drukkerij- en andere ondersteunende medewerkers zijn buiten beschouwing gelaten. Dit zou namelijk teveel problemen opleveren bij de toerekening van de bestede tijd aan de uitvoering van een bepaalde maatregel. Als directe medewerkers zijn beschouwd de betrokken bureaumedewerkers van de provinciale 
griffie en van de Provinciale Raad voor de Volksgezondheid, de beleidsmedewerkers van de samenwerkingsverbanden van instellingen, van de streekgewesten van gemeenten en van verzekeraars en de leden van de Plangroep (zie hierna). Degenen die de achterban of superieuren van de direct betrokkenen vormden, zoals het bureauhoofd van de provinciale griffie, de gedeputeerde, het Dagelijks en Algemeen Bestuur van de Provinciale Raad, bestuurderen van de samenwerkingsverbanden en de streekgewesten zijn eveneens buiten beschouwing gelaten. De reden hiervoor is het feit dat de scheiding tussen directe en indirecte betrokkenheid dusdanig vaag wordt dat hier onmogelijk een zinnige uitspraak over kan worden gedaan. De vraag die rijst is dan namelijk welk overleg met welke superieur of welke achterban wel meetelt en welke niet. Het gevolg van deze afbakening is wel dat de meting de minimaal bestede tijd oplevert.

In schema 7.7 wordt een overzicht gegeven van degenen die wel en niet bij de meting zijn betrokken.

Schema 7.7 Direct en indirect betrokkenen bij de meting van de totstandkoming van het verpleeghuisplan

\begin{tabular}{l|l}
\hline Direct betrokken: & Indirect betrokken: \\
\hline bureaumedewerkers provinciale griffie & $\begin{array}{l}\text { bureauhoofd provinciale griffie } \\
\text { gedeputeerde }\end{array}$ \\
bureaumedewerkers Provinciale Raad & $\begin{array}{l}\text { leden Dagelijks Bestuur Provinciale } \\
\text { Raad voor de Volksgezondheid } \\
\text { voor de Volksgezondheid }\end{array}$ \\
$\begin{array}{l}\text { leden Algemeen Bestuur Provinciale } \\
\text { Raad voor de Volksgezondheid } \\
\text { bestuursleden van samenwerkingsver- } \\
\text { banden van instellingen } \\
\text { beleidsmedewerkers samenwerkings- } \\
\text { verbanden van instellingen } \\
\text { beleidsmedewerkers streekgewesten } \\
\text { van gemeenten } \\
\text { betrokken financiers }\end{array}$ & $\begin{array}{l}\text { gemeenten } \\
\text { achterban financiers } \\
\text { administratieve, archief-, drukkerij- en } \\
\text { andere } \\
\text { ondersteunende medewerkers }\end{array}$ \\
\hline
\end{tabular}

Ten derde moet duidelijk zijn welke activiteiten van de uitvoerenden zijn meegerekend en welke niet. Hiervoor geldt hetzelfde als voor de afbakening van de betrokkenen: uitsluitend de directe planwerkzaamheden zijn gemeten. In de praktijk betekende dit dat de planwerkzaamheden van de bureaumedewerkers in hun geheel zijn meegerekend, aangezien zij gedurende bepaalde perioden permanent met de planning zijn bezig geweest.

De volgende werzaamheden van de leden van de Plangroep Langerdurende Gezondheidszorg zijn bij de inventarisatie inbegrepen:

- de voorbereiding van de vergadering (het doorlezen van vergaderstukken, het voeren van vooroverleg met de achterban);

- de duur van de vergadering zelf;

- de nabespreking met de achterban (dat wil zeggen binnen bureaus, directies, met andere verpleeghuizen, binnen samenwerkingsverbanden).

Voor wat de andere ondervraagden betreft zijn uitsluitend werkzaamheden meegerekend die direct gerelateerd konden worden aan planactiviteiten. Voorbeelden van dergelijke werkzaamheden zijn het opstellen van adviezen, het bijwonen van vergaderingen van de plangroep en de voorbereiding daarvan. Buiten beschouwing zijn gebleven het plegen van overleg met superieuren of de achterban. 
reistijd en dergelijke. Evenmin zijn vergaderingen, waarvan de planning slechts één onderdeel op de agenda was, meegerekend. Het is namelijk praktisch onmogelijk achteraf aan te geven hoeveel tijd dat ene agendapunt gekost heeft (zie hoofdstuk 4). $\mathrm{Er}$ is naar gestreefd de meting zoveel mogelijk te beperken tot duidelijk af te bakenen, eenduidig te onderscheiden en afzonderlijke planactiviteiten. Dit voorkomt onoplosbare toerekeningsvraagstukken. Het gevolg is wel dat sprake is van een minimale schatting.

Ten aanzien van de dataverzameling dient eveneens een aantal zaken te worden geëxpliciteerd. Dit betreft de manier waarop de gegevens zijn verzameld.

Bij het inventariseren was de werkwijze als volgt. Eerst is met degenen die sleutelposities innamen in de procedure van de totstandbrenging van het verpleeghuisplan een aantal open interviews gehouden. Deze sleutelpersonen waren beleidsmedewerkers van het bureau Volksgezondheid van de provinciale griffie en van het bureau van de Provinciale Raad voor de Volksgezondheid. Zij zijn nagenoeg permanent bezig geweest met de totstandbrenging van het verpleeghuisplan. Zij hebben geschetst hoe de procedure in de praktijk is verlopen en wie "tijdelijk" bij de uitvoering betrokken zijn geweest. "Tijdelijk uitvoerenden" zijn beleidsmedewerkers of commissieleden van adviserende instanties. Aan de hand van deze opgave zijn de "tijdelijke" uitvoerenden telefonisch benaderd. Zij zijn geinterviewd met behulp van gestructureerde vragen (zie bijlage 4). Aan personen die bij dezelfde soort organisaties werkten, bijvoorbeeld alle betrokken beleidsmedewerkers van de samenwerkingsverbanden of alle betrokken beleidsmedewerkers van de Streekgewesten, werden identieke vragen voorgelegd.

ledereen die direct bij de uitvoering betrokken was, is op deze wijze geïnterviewd. Aan de geïnterviewden is gevraagd de tijd te schatten die zij, als direct betrokkenen, hadden besteed aan de totstandbrenging van het plan. Zij werden verzocht alle directe werkzaamheden, zoals het schrijven en het aanpassen van nota's, adviezen bij de schatting te betrekken.

De tijd die de leden van het Dagelijks Bestuur en het Algemeen Bestuur van de Provinciale Raad voor de Volksgezondheid hebben besteed aan de totstandkoming van het verpleeghuisplan is niet meegerekend, aangezien het steeds slechts losse agendapunten van uitgebreidere vergaderingen betrof. Dat neemt nie: weg dat de totaal bestede tijd aanzienlijk zal zijn geweest. Het Dagelijks Bestuur van de Provinciale Raad bestond aanvankelijk, bij het begin van de planprocedure, immers uit vijf personen en na oktober 1987 uit zeven personen. Het Algemeen Bestuur bestond aanvankelijk uit veertien en later uit 28 leden. Omdat het over een dergelijk grote groep personen gaat, zal wel steeds worden vermeld wanneer en hoe vaak deze besturen over het plan of onderdelen daarvan vergaderd hebben.

Deze afbakeningen impliceren dat sprake is van een conservatieve schatting. Slechts de minimaal bestede tijd is bepaald. De reden hiervoor is ten eerste dat een bepaalde hoeveelheid tijd niet toe te rekenen is. Het is onduidelijk aan welke activiteit de tijd toegerekend moet worden. Ten tweede wordt in bepaalde gevallen verdere toedeling onbetrouwbaar. Er moeten dan keuzen gemaakt worden die slechts een schijnbetrouwbaarheid teweeg brengen. Duidelijk is wel dat de tijd die is besteed aan de uitvoering van artikel 4 in ieder geval niet minder is geweest dan de tijd die hier is bepaald.

Bovendien moet worden vermeld dat de gegevensverzameling heeft plaatsgevonden tussen januari 1988 en januari 1989. De inventarisatie kon niet in één aaneengesloten periode aangezien men nog met de planning bezig was. Verder dient te worden opgemerkt dat uitsluitend is gekeken naar de procedures en de bestede tijd en niet naar de inhoud van de plannen. 
Aan alle leden van de plangroep (uitgezonderd degenen die slechts één of twee vergaderingen hadden bijgewoond of inmiddels een andere betrekking hadden aanvaard) is gevraagd te schatten hoeveel tijd zij aan bovengenoemde activiteiten hebben besteed. Volledigheidshalve moet hieraan worden toegevoegd dat de tijd die de leden van de plangroep in het kader van deze planning hebben besteed aan het reizen van en naar bijeenkomsten, het bijhouden van vakliteratuur, het volgen van cursussen niet is meegerekend. Het betreft hier immers geen directe plan-activiteiten.

In het geval het historische schattingen betrof zijn deze gemaakt door één leidinggevencie persoon voor alle betrokkenen van het desbetreffende bureau of afdeling. In het geval het actuele metingen betrof zijn alle direct uitvoerenden individueel gevraagd. Hierdoor bestaat enige twijfel omtrent de betrouwbaarheid van de meting.

Bij de berekening van de bestede tijd zijn de volgende uitgangspunten gehanteerd:

- één full time dag bestaat uit acht uren;

- éen full time week bestaat uit viff dagen;

- één fuli time maand bestaat uit 22,5 dagen $(4,5 \times 5)$;

\section{§ 7.3.1 De in de praktijk gevolgde planprocedure vòòr Dekker en de tijd die deze} in beslag heeft genomen

In december 1983 ontvangen Provinciale Staten van Limburg de aanwijzing ex artikel 4 Wet Ziekenhuisvoorzieningen tot het maken van een ontwerpplan verpleeghuizen voor de gezondheidsregio's Noord- en Zuid-Limburg. Het is de bedoeling dat de hele procedure (inclusief de inspraakronde, het overleg met naburige provincies) binnen 18 maanden wordt afgerond. Het College voor Ziekenhuisvoorzieningen is inmiddels verzocht een bouwkundige en een planmatige inventarisatie te maken van het aanbod en het gebruik van verpleeghuisvoorzieningen in de provincie Limburg.

In de aanwijzing stelt de staatssecretaris dat de planningsactiviteiten met betrekking tot de verpleeghuizen moeten worden ingepast in de meer integrale planning volgens de Wet Voorzieningen Gezondheidszorg. Dit doen Gedeputeerde Staten ertoe besluiten behalve de verpleeghuizen ook de daarmee samenhangende voorzieningen, zoals geriatrische en observatie-afdelingen en poliklinieken van zowel algemene als psychiatrische ziekenhuizen, bij de planning te betrekken. Bovendien leidt afstemming van de planning volgens de Wet Ziekenhuisvoorzieningen op de Wet Voorzieningen Gezondheidszorg ertoe dat ook de instellingen en de gebruikers bij de planvoorbereiding betrokken dienen te worden.

In de provincie Limburg is men vanaf 1982 bezig met het voorbereiden van de invoering van de Wet Voorzieningen Gezondheidszorg. In het kader daarvan houdt het provinciaal bestuur zich van september 1982 tot juli 1984 onder andere bezig met het ontwikkelen en opzetten van een planningsstructuur waarin zowel de Wet Ziekenhuisvoorzieningen als de Wet Voorzieningen Gezondheidszorg tot hun recht komen. Dit resulteert in de nota "Bestuursorganisatorische maatregelen ten behoeve van de invoering van de Wet Voorzieningen Gezondheidszorg in de provincie Limburg" (1984). Hierin is onder meer opgenomen de "Planprocedure en provinciale adviesstructuur op het terrein van de gezondheidszorg", waarin de te 
volgen planprocedure uiteengezet wordt. Deze procedure voorziet in de mogelijkheid het veld van de gezondheidszorg (via de Samenwerkingsverbanden), de gemeenten (door middel van de Streekgewesten) en de financiers (in dit verband verstaat men hieronder: de ziekenfondsen) bij de planvoorbereiding te betrekken. Zoals eerder vermeld, zijn de bestuurskosten van deze activiteiten niet meegerekend.

Vervolgens werkt men bij de provinciale griffie in de periode van juni 1985 tot juni 1986 volgens de schatting van de betrokken beleidsmedewerker ongeveer vier maanden full time (= 90 dagen) aan de opstelling van een concept-beleidsvisie. De conceptbeleidsvisie bevat de uitgangspunten van het provinciaal bestuur ten aanzien van de ontwikkeling van de gezondheidszorg in de provincie, toegespitst op de langerdurende gezondheidszorg.

De weg die dit concept dient af te leggen alvorens voorlopig te worden vastgesteld verloopt als volgt. Het concept wordt eerst "ambtelijk" besproken binnen het bureau volksgezondheid, dan binnen de hoofdgroep welzijn en vervolgens met de verantwoordelijke gedeputeerde. Tenslotte stellen Gedeputeerde Staten de concept-beleidsvisie, nadat deze is bijgesteld aan de hand van het intern gevoerde overleg, voorlopig vast. Dit concept wordt ter kennisname aan de vaste commissie voor Maatschappelijk Werk en Volksgezondheid gezonden. Hierna krijgen de Provinciale Raad voor de Volksgezondheid, de Algemene Samenwerkingsverbanden Gezondheidszorg, de ziekenfondsen en de Streekgewesten de gelegenheid te adviseren over het concept.

Op 17 juni 1986 ontvangt de Provinciale Raad voor de Volksgezondheid de adviesaanvraag van Gedeputeerde Staten aangaande de concept-beleidsvisie met betrekking tot de langerdurende gezondheidszorg. Dit advies dient voor 1 oktober 1986 gereed te zijn. Behalve het voorlopige standpunt van Gedeputeerde Staten bevat het concept tevens een aankondiging van de op handen zijnde geclausuleerde planopdracht. Op respectievelijk 14 en 28 augustus 1986 bespreken het Dagelijks Bestuur en het Algemeen Bestuur van de Provinciale Raad deze adviesaanvraag.

Het bureau van de Raad krijgt dan de opdracht een advies te vervaardigen, dat eerst aan de directeur wordt voorgelegd. Tenslotte dienen het Dagelijks Bestuur en het Algemeen Bestuur het advies goed te keuren (zie 25 september 1986), alvorens dit wordt verstuurd aan Gedeputeerde Staten. Een dergelijke adviesaanvraag kost het bureau van de Raad ongeveer drie weken full time (= 15 dagen).

De gemeenten ontvangen eind juni 1986 via de Streekgewesten een uitnodiging tot het bijwonen van een hoorzitting omtrent de concept-beleidsvisie. Drie gewesten gaan hierop in. Twee gewesten brengen schriftelijk advies uit. Aan de beleidsmedewerkers van de Streekgewesten is gevraagd een schatting te maken van de tijd die zij hebben besteed aan de opstelling van het advies. Een dergelijke procedure houdt het volgende in:

- het voorbespreken van de inhoud van het advies door het bureau van het streekgewest met een ambtelijke werkgroep;

- het opstellen van een concept door het bureau;

- het bespreken van het concept in een ambtelijk en in een bestuurlijk overleg; en tenslotte eventueel

- het aanpassen van het concept door het bureau.

Gemiddeld hebben de bureaumedewerkers van de Streekgewesten naar eigen schatting elk negen dagen full time besteed aan het adviseren omtrent de concept- 
beleidsvisie. In totaal hebben de Streekgewesten dus $\mathbf{4 5}$ dagen full time nodig gehad.

De ziekenfondsen worden op 5 september 1986 voor een "consultatief overleg" uitgenodigd. De concept-beleidsvisie komt hier aan de orde naast een aantal andere onderwerpen.

Ook de Algemene Samenwerkingsverbanden Gezondheidszorg en Maatschappelijke Dienstverlening ontvangen in september 1987 een adviesaanvraag met betrekking tot de concept-beleidsvisie. Elk van de vijf Samenwerkingsverbanden brengt een advies uit.

Aan de hand van het hierboven genoemde overleg en de schriftelijke adviezen stelt de provinciale griffie vanaf oktober 1986 de concept-beleidsvisie bij. In januari 1987 volgt weer een interne overlegronde (binnen het bureau, de hoofdgroep en met de geduteerde), waarna in februari 1987 de definitieve beleidsvisie wordt vastgesteld door Gedeputeerde Staten. Naar schatting van de beleidsmedewerker bedragen de bestuurskosten voor de provinciale griffie ruim éen maand full time $(=\mathbf{2 2 , 5}$ dagen) vanaf het moment waarop de concept-beleidsvisie voorlopig is goedgekeurd tot het moment van de definitieve vaststelling van de beleidsvisie.

Op 26 augustus 1986 verzoekt Gedeputeerde Staten de Provinciale Raad voor de Volksgezondheid commentaar te geven op de notitie "Dependancevorming door verpleeghuizen bij bejaardenoorden" (voor 1 november 1986). Op 23 oktober wordt dit verstrekt door de Raad.

Inmiddels ontvangt de Provinciale Raad voor de Volksgezondheid van Gedeputeerde Staten op 16 september 1986 (dus nog voordat de beleidsvisie definitief is) de opdracht alvast te beginnen met het in concept opstellen van de voorontwerpplannen voor de langerdurende gezondheidszorg in de gezondheidsregio's Noord- en Zuid-Limburg. Deze opdracht dient binnen acht maanden voltooid te zijn en bevat de volgende onderdelen:

- het opstellen van het deelplan voor de hoofdgroep verpleeghuizen ex Wet Ziekenhuisvoorzieningen;

- het opstellen van een deelplan GAAZ'en/observatie-afdelingen in Algemene Ziekenhuizen en Algemeen Psychiatrische Ziekenhuizen ex Wet Voorzieningen Gezondheidszorg;

- het instellen van een plangroep en de samenstelling ervan doorgeven aan Gedeputeerde Staten;

- het periodiek informeren van Gedeputeerde Staten over de voortgang van de planning.

Bij de opdracht is tevens een blauwdruk gevoegd, volgens welk stramien de concept-voorontwerpplannen op het terrein van de langerdurende gezondheidszorg dienen te worden opgesteld.

Op 25 september 1986 bespreekt het Algemeen Bestuur van de Provinciale Raad de concept-beleidsvisie en op 23 oktober 1986 de planopdracht van Gedeputeerde Staten.

In november 1986 wordt gewerkt aan het instellen van de Plangroep Langerdurende Gezondheidszorg. Over de samenstelling van de plangroep hebben Gedeputeerde Staten de volgende richtlijnen gegeven. Er dienen zitting te hebben deskundigen op het gebied van de langerdurende gezondheidszorg en op het gebied van het ouderenbeleid, ambtenaren van het bureau volksgezondheid en het 
bureau ouderenbeleid der provinciale griffie en vertegenwoordigers van de Algemene Samenwerkingsverbanden Gezondheidszorg in Limburg.

De Provinciale Raad is vrij in het kiezen van de aantallen, de personen en het eventueel uitbreiden van de categorieën. Het Dagelijks Bestuur van de Provinciale Raad besluit dat per Samenwerkingsverband één persoon en van de overige categorieën maximaal twee personen zitting zullen hebben in de plangroep. Verder zal het bureau van de Provinciale Raad drie leden leveren. Voorzitter is de voorzitter van de Raad. De categorie "financiering" wordt toegevoegd en de Inspecties voor de Volksgezondheid en voor de Geestelijke Volksgezondheid worden gevraagd ieder éen adviseur te leveren. Later is het Algemeen Bestuur van de Raad van mening dat ook de eerstelijn vertegenwoordigd moet zijn. Dit heeft als resultaat dat de plangroep uiteindelijk bestaat uit 18 leden en twee adviseurs.

Verder besluit het Dagelijks Bestuur van de Provinciale Raad dat de plangroep alleen bijeen zal worden geroepen wanneer naar het oordeel van de voorzitter een voldoende substantiële agenda voor een dergelijke bijeenkomst voor handen is (het zwaartepunt van de planvoorbereiding ex Wet Ziekenhuisvoorzieningen / Wet Voorzieningen Gezondheidszorg dient immers bij de Provinciale Raad zelf te liggen, aldus het Statenbesluit van 20 september 1984). Hierna besteedt het Algemeen Bestuur nog tweemaal in één agendapunt en het Dagelijks Bestuur eenmaal aandacht aan diverse notities van de plangroep. Op 11 december $1986 \mathrm{komt}$ de plangroep voor het eerst bij elkaar.

Intussen beginnen de bureaumedewerkers van de Provinciale Raad te werken aan de verschillende planonderdelen, zoals de planmatige en bouwkundige inventarisatie (de inventarisatie van het College voor Ziekenhuisvoorzieningen dateert weliswaar uit 1986, maar bevat gegevens van 1982 en behoeft daarom bijstelling). het deelplan GAAZ'en, een voorlopige opzet en indeling van de concept-voorontwerpplannen.

Op 17 februari 1987 ontvangt de Provinciale Raad van Gedeputeerde Staten de definitieve beleidsvisie. Het financieel kader ontbreekt nog steeds, want pas op 16 april 1987 maakt de staatssecretaris dit bekend aan Provinciale Staten van Limburg.

In juni 1987 rondt het bureau van de Provinciale Raad de inleiding en de eerste twee hoofdstukken van de concept-voorontwerpplannen voor de beide regio's af. Hierna komt de plangroep op 11 juni 1987 voor de tweede maal bijeen ter bespreking van bovengenoemde stukken.

Op 30 juni 1987 sturen Gedeputeerde Staten aan de Provinciale Raad het op Limburg afgestemde financieel kader, waarbinnen de planning van de verpleeghuissector in de gezondheidsregio's Noord-en Zuid-Limburg dient plaats te vinden.

Op 7 juli 1987 vraagt de Provinciale Raad aan de Algemene Samenwerkingsverbanden Gezondheidszorg in Limburg advies over:

- de verdeling van de verpleeghuiscapaciteit in 1992 en 1996;

- de (on)mogelijkheid van overplaatsing van psycho-geriatrische patiënten.

Elk van de vijf Samenwerkingsverbanden reageert schriftelijk op dit verzoek.

Op 26 oktober 1987 voltooit de Provinciale Raad het deelplan GAAZ'en/observatieafdelingen voor ouderen in algemene ziekenhuizen en algemene psychiatrische ziekenhuizen. Hiertoe is overigens een adhoc-werkgroep bestaande uit drie leden en bureaumedewerkers van de Raad ingesteld, die één keer heeft vergaderd. Dit 
deelplan heeft het bureau en de leden van de werkgroep twee weken full time (= 10 dagen) gekost. De Algemene Samenwerkingsverbanden worden ook over dit deelplan geraadpleegd. Drie Samenwerkingsverbanden gaan hierop in.

Kort daarop, begin november 1987, rondt het bureau van de Provinciale Raad ook hoofdstuk III van de concept-voorontwerpplannen af.

Hierna vindt op 4 en 11 november 1987 de derde vergadering (in twee delen) van de plangroep Langerdurende Gezondheidszorg plaats. De vierde en tevens laatste bijeenkomst is op 9 december 1987 . Tijdens deze bijeenkomst komen de viteindelijke concept-voorontwerpplannen Langerdurende Gezondheidszorg 1988-1996 voor de regio's Noord- en Zuid-Limburg aan de orde.

In totaal is de plangroep vijfmaal bijeen geweest, waarvan éen vergadering twee bijeenkomsten besloeg. Gemiddeld zijn bij deze vergaderingen 16 personen aanwezig (inclusief de bureaumedewerkers van de Raad). Met deze vergaderingen zijn in totaal 64 full time dagen gemoeid.

Tenslotte biedt de Provinciale Raad op 24 december 1987 de Concept-voorontwerpplannen Langerdurende Gezondheidszorg 1988-1992 voor de gezondheidsregio's Noord- en Zuid-Limburg aan Gedeputeerde Staten aan. Overigens besluit de Provinciale Raad op het allerlaatste moment om de plannen de status van "adviezen" en niet van "concept-voorontwerpplannen" te geven. Als redenen worden hiervoor gegeven dat de concepten niet stroken met de door Gedeputeerde Staten geuite wensen ten aanzien van dependancevorming en het vooruitlopen op aanstaande wetswijzigingen (Provinciale Raad, februari 1988). Hier wordt gedoeld op de verwachte wijzigingen naar aanleiding van de adviezen van de Commissie-Dekker.

De bureaumedewerkers van de Provinciale Raad schatten dat het opstellen van de concept-voorontwerpplannen in totaal aan de Raad ongeveer één jaar full time (= 270 dagen) heeft gekost.

Gedurende de tijd dat de Provinciale Raad voor de Volksgezondheid zich hiermee bezighoudt, onderneemt de provinciale griffie de volgende activiteiten:

- het bijwonen van de bijeenkomsten van de plangroep langerdurende gezondheidszorg (behalve participatie hierin vindt ook intern overleg omtrent de voortgang en het besprokene plaats):

- het voeren van overleg over dependancevorming (dit houdt in dat de uitgangspunten worden geformuleerd ten aanzien van het te volgen beleid van de provincie op het gebied van de dependancevorming van verpleeghuizen bij bejaardenoorden, alsmede dat een standpunt wordt bepaald ten aanzien van de te ondersteunen projecten. Eigenlijk zou dit vraagstuk pas na afloop van de planprocedure aan de orde moeten komen, maar de ontwikkelingen in het veld gaan sneller dan het maken van plannen ...);

- het plegen van overleg met het ministerie van Welzijn, Volksgezondheid en Cultuur over de berekeningsmethodiek en de vaststelling van financiële kaders;

- schriftelijk overleg met de provincie Noord-Brabant over patiëntenstromen tussen de provincies.

Dit alles, vanaf het moment waarop de beleidsvisie wordt vastgesteld tot het ogenblik waarop de concept-voorontwerpplannen door de Provinciale Raad voor de Volksgezondheid worden aangeboden, vergt voor de beleidsmedewerkers bij de provinciale griffie naar schatting ongeveer één maand full time (= 22,5 dagen). 


\begin{tabular}{|c|c|c|c|}
\hline Tijdstippen: & Activiteiten: & Actoren: & $\begin{array}{l}\text { Benodigde } \\
\text { tijd (in full } \\
\text { time dagen): }\end{array}$ \\
\hline juni ' 85 tot juni ' 86 & $\begin{array}{l}\text { opstellen concept- } \\
\text { beleidsvisie }\end{array}$ & provinciale griffie & 90 dagen \\
\hline juni ' 86 & $\begin{array}{l}\text { adviseren over con- } \\
\text { cept-beleidsvisie }\end{array}$ & $\begin{array}{l}\text { Provinciale Raad voor de } \\
\text { Volksgezondheid }\end{array}$ & 15 dagen \\
\hline juni ' 86 & $\begin{array}{l}\text { adviseren over con- } \\
\text { cept-beleidsvisie }\end{array}$ & streekgewesten & 45 dagen \\
\hline juli '86 & $\begin{array}{l}\text { adviseren over con- } \\
\text { cept-beleidsvisie }\end{array}$ & $\begin{array}{l}\text { Algemene Samenwerkings- } \\
\text { verbanden Gezondheidszorg } \\
\text { en Maatschappelijke Dienst- } \\
\text { verlening }\end{array}$ & $\#$ \\
\hline okt. ' 86 tot febr. ' 87 & opstellen beleidsvisie & provinciale griffie & 22,5 dagen \\
\hline okt. ' 86 tot okt. ' 87 & $\begin{array}{l}\text { opstellen deelplan } \\
\text { GAAZ'en }\end{array}$ & $\begin{array}{l}\text { Provinciale Raad voor de } \\
\text { Volksgezondheid }\end{array}$ & 10 dagen \\
\hline juli '87 & $\begin{array}{l}\text { adviseren over verde- } \\
\text { ling en plaatsing psy- } \\
\text { cho-geriatrische pati- } \\
\text { enten }\end{array}$ & $\begin{array}{l}\text { Algemene Samenwerkings- } \\
\text { verbanden Gezondheidszorg } \\
\text { en Maatschappelijke Dienst- } \\
\text { verlening }\end{array}$ & $\#$ \\
\hline dec. '86 tot dec. ' 87 & $\begin{array}{l}\text { adviseren over con- } \\
\text { cept-voorontwerp- } \\
\text { plannen }\end{array}$ & $\begin{array}{l}\text { plangroep langerdurende ge- } \\
\text { zondheidszorg }\end{array}$ & 64 dagen \\
\hline sept. ' 86 tol dec. ' 87 & $\begin{array}{l}\text { diverse overlegsitua- } \\
\text { ties met betrekking } \\
\text { tot de planning }\end{array}$ & provinciale griffie & 22,5 dagen \\
\hline \multirow[t]{2}{*}{ sept. '86 tot dec. ' 87} & $\begin{array}{l}\text { opstellen concept- } \\
\text { voorontwerpplannen }\end{array}$ & $\begin{array}{l}\text { Provinciale Raad voor de } \\
\text { Volksgezondheid }\end{array}$ & 270 dagen \\
\hline & & $\#=$ in totaal: & 71,5 dagen \\
\hline Totaal: & & & 610,5 dagen \\
\hline
\end{tabular}

Tot dan toe heeft de provinciale griffie dus in totaal ongeveer zes maanden full time aan de totstandkoming van de planning van de langer durende gezondheidszorg gewerkt. In tabel 7.2 is een overzicht gegeven van de tijd die gemiddeld is besteed aan de diverse activiteiten die deel uitmaakten van het planproces in het kader van de Wet Ziekenhuisvoorzieningen voor het plan-Dekker.

\section{§ 7.3.2 De in de praktijk gevolgde planprocedure nà Dekker en de tijd die deze in beslag heeft genomen}

Op 28 januari 1988 vindt alsnog bespreking plaats van het advies (conceptvoorontwerpplan) in het Algemeen Bestuur van de Provinciale Raad. Naar aanleiding hiervan acht men bijstelling overigens niet noodzakelijk. Hierna volgt toezending van het definitieve advies aan alle leden van het Algemeen Bestuur, alle plangroepleden, de Samenwerkingsverbanden, de verpleeghuizen en, op verzoek, aan derden. 
Terwijl het advies van de Provinciale Raad gereed ligt, is intussen de provinciale griffie gedurende de maanden januari en februari 1988 in afwachting van een nieuwe aanwijzing van de staatssecretaris, gezien de ontwikkelingen rondom de aanbevelingen van de commissie Dekker. Deze aangepaste aanwijzing blijt echter uit. Wel maakt het ministerie van Welzijn, Volksgezondheid en Cultuur op 4 maart 1988 bekend dat de integrale planning conform de Wet Voorzieningen Gezondheidszorg niet gecontinueerd zal worden. In maart en april 1988 houdt de provinciale griffie zich bezig met het voeren van overleg, binnen het bureau Volksgezondheid en tussen het bureau en het ministerie van Welzijn, Volksgezondheid en Cultuur, omtrent de manier waarop een plan er dan dient uit te zien. Duidelijk is geworden dat de plannen globaler moeten zijn. Hoe globaal is onbekend, ze moeten immers wel te toetsen zijn aan het financieel kader en aan het bouwplafond.

Nadat hierover overeenstemming is bereikt, houden gedurende de maanden mei en juni 1988 een beleidsmedewerker en het bureauhoofd van de provinciale griffie zich bezig met het schrijven van de aangepaste concept-voorontwerpplannen. Dit heeft hun samen naar schatting één maand full time (= 22,5 dagen) gekost. Wanneer het concept gereed is volgt de gebruikelijke overlegronde binnen de hoofdgroep Welzijn en met de verantwoordelijke gedeputeerde.

Op 30 augustus 1988 worden de herziene concept-voorontwerpplannen vastgesteld door Gedeputeerde Staten.

Eind augustus 1988 wordt dit concept toegezonden aan de Provinciale Raad voor de Volksgezondheid, aan de Algemene Samenwerkingsverbanden Gezondheidszorg en aan de verzekeraars. Tot deze laatste groep behoren de vier ziekenfondsen, het Instituut Ziektekostenverzekering Ambtenaren-Limburg en het Kontaktorgaan Landelijke Organisaties van Ziektekostenverzekeraars / Kontaktkommissie Publiekrechtelijke Ziektekostenregelingen voor ambtenaren namens de particuliere verzekeraars. Hen wordt verzocht voor 15 oktober 1988 advies uit te brengen.

Op 6 september 1988 ontvangt de Provinciale Raad deze adviesaanvraag. Het bureau van de Raad stelt hiertoe een notitie op. Aan de opstelling van deze notitie is overleg met de Samenwerkingsverbanden in verband met regionale kwesties en incidenteel met plangroepleden vooraf gegaan. Dit heeft het bureau, naar schatting, ongeveer drie weken full time (= 15 dagen) gekost. Voordat deze notitie op respectievelijk 13 en 27 oktober 1988 in het Dagelijks en Algemeen Bestuur aan de orde komt, heeft een ad hoc-werkgroep verpleeghuisplanning, bestaande uit het Dagelijks Bestuur aangevuld met vijf leden van het Algemeen Bestuur, zich er reeds over gebogen. Op 19 oktober 1988 wordt het advies verstuurd onder voorbehoud van goedkeuring door het Algemeen Bestuur.

De vijf Algemene Samenwerkingsverbanden krijgen eveneens anderhalve maand om te adviseren. De procedure binnen deze Samenwerkingsverbanden is veelal als volgt. Door de respectievelijke bureaus worden concept-adviezen opgesteld. Hierover brengen vooraf of achteraf de verpleeghuizen uit de desbetreffende regio, verenigd in een Cluster, een Subcluster of de Werkgroep Verpleeghuizen, (pré)advies uit. Vervolgens bespreken de Samenwerkingsverbanden de concepten, waarna de besturen deze vaststellen. In de loop van oktober 1988 worden de adviezen naar Gedeputeerde Staten gestuurd. Aan de bureaus van de vijf Samenwerkingsverbanden heeft dit in totaal naar schatting ongeveer $\mathbf{2 0}$ dagen full time gekost. 
De verzekeraars brengen een gezamenlijk advies uit. De vertegenwoordigers van de vier ziekenfondsen stellen het advies op en dit wordt mede-ondertekend door de regiovertegenwoordigers van de particuliere verzekeraars. Op 11 oktober 1989 wordt dit advies verstrekt aan Gedeputeerde Staten. In totaal heeft dit de verzekeraars naar schatting $\mathbf{5 0}$ dagen full time gekost.

In oktober 1988 voert de provinciale griffie overleg met het ministerie van Welzijn, Volksgezondheid en Cultuur over het concept. Het ministerie geeft dan te kennen dat het concept op een aantal onderdelen concreter en van meer financiële cijfers voorzien dient te zijn. Daarnaast krijgt de griffie (ongevraagd) advies van de Provinciale Ziekenhuisraad.

In januari 1989 wordt het concept herschreven. Dit kost de griffie naar schatting twee à drie weken full time (= 13 dagen). Hierop volgt opnieuw overleg met de gedeputeerde. Eind januari 1989 is het ontwerpplan gereed, waarna het in februari 1989 wordt gepubliceerd.

Op 14 februari 1989 wordt het vastgesteld door Gedeputeerde Staten. Met ingang van 1 maart 1989 start de inspraakprocedure. Tot 1 mei 1989 is het mogelijk om bezwaren in te dienen. In mei 1989 volgt de hoorzitting omtrent de ingediende bezwaren. Hierna kan het concept in juni of september 1989 aan Provinciale Staten ter goedkeuring worden voorgelegd, waarna het aan de staatssecrelaris kan worden aangeboden. Op 11 februari 1991 wordt in de Staatscourant bekend gemaakt dat het verpleeghuisplan voor Limburg is vastgesteld. De tijd die deze politieke besluitvorming heeft gekost, is niet meer meegenomen.

In tabel 7.3 is een overzicht gegeven van de tijd die sedert de voorstellen van de Commissie-Dekker gemiddeld is besteed aan diverse activiteiten in het kader van de totslandkoming van het verpleeghuisplan van de provincie Limburg.

\begin{tabular}{|c|c|c|c|}
\hline Tijdstippen: & Activiteiten: & Actoren: & $\begin{array}{l}\text { Benodigde } \\
\text { tijd (in full } \\
\text { time dagen): }\end{array}$ \\
\hline mei ' 88 tot juni ' 88 & $\begin{array}{l}\text { opstellen concept-vooront- } \\
\text { werpplannen }\end{array}$ & provinciale griffie & 22,5 dagen \\
\hline sept. ' 88 tot okt. ' 88 & $\begin{array}{l}\text { adviseren over concept- } \\
\text { voorontwerpplannen }\end{array}$ & $\begin{array}{l}\text { Provinciale Raad voor de } \\
\text { Volksgezondheid }\end{array}$ & 15 dagen \\
\hline sept. ' 88 tot okt. ' 88 & $\begin{array}{l}\text { adviseren over concept- } \\
\text { voorontwerpplannen }\end{array}$ & $\begin{array}{l}\text { Algemene Samenwerkings- } \\
\text { verbanden Gezondheidszorg } \\
\text { en Maatschappelijke Dienst- } \\
\text { verlening }\end{array}$ & 20 dagen \\
\hline sept. ' 88 tot okt. ' 88 & $\begin{array}{l}\text { adviseren over concept- } \\
\text { voorontwerpplannen }\end{array}$ & verzekeraars & 50 dagen \\
\hline jan. '89 & $\begin{array}{l}\text { herschrijven concept- } \\
\text { voorontwerpplannen }\end{array}$ & provinciale griffie & 13 dagen \\
\hline Totaal: & & & 120,5 dagen \\
\hline
\end{tabular}

Wanneer men de aan de totstandkoming van het verpleeghuisplan bestede tijd van "vòòr en nà Dekker" bij elkaar optelt dan levert dit het volgende op (zie tabel 7.4). 
Tabel 7.4 De totaal bestede tijd aan de totstandkoming van het verpleeghuisplan (in full time dagen)

\begin{tabular}{ll}
\hline "Vòòr Dekker" & 610,5 dagen \\
"Nà Dekker" & 120,5 dagen \\
\hline \hline Totaal: & 731 dagen \\
\hline
\end{tabular}

Overigens mag men uit tabel 7.4 niet de conclusie trekken dat de opstelling van de plannen "vòòr Dekker" vijł maal zveel tijd kost als de planning "nà Dekker". Men is immers niet helemaal opnieuw begonnen met de opstelling van de plannen. Gegevens en adviezen waren immers reeds verzameld.

In totaal is van juni 1985 tot januari 1989 (maar eigenlijk tussen december 1983 en februari 1991) naar schatting ruim 700 full time dagen besteed aan directe activiteiten aangaande de opstelling van de concept-verpleeghuisplannen van de regio's Noord- en Zuid-Limburg in de provincie Limburg. Dit is omgerekend ruim drie mensjaren. Het gevolg van een dergelijk lange doorlooptijd is dat de plannen al verouderd zijn, voordat ze ten uitvoer zijn gebracht. Aanpassing van de verouderde plannen kost vervolgens opnieuw de nodige tijd.

Wanneer men de verdeling beschouwd van de tijd die door de verschillende actoren is besteed aan de opstelling van het verpleeghuisplan (zie figuur 7.1) dan valt op dat de Provinciale Raad voor de Volksgezondheid hieraan verreweg de meeste tijd heeft besteed, gevolgd door de provinciale griffie. Dit ligt echter nogal voor de hand, aangezien de provincie de voornaamste uitvoerder is van de planning ex Wet Ziekenhuisvoorzieningen. De overige betrokkenen nemen echter gezamenlijk maar liefst één derde deel van de totaal bestede tijd voor hun rekening, terwijl zij in feite slechts zijdelings bij de uitvoering betrokken zijn. 
Figuur 7.1 De verdeling van de actoren van de bestede tijd aan de opstelling van het verpleeghuisplan in de provincie Limburg

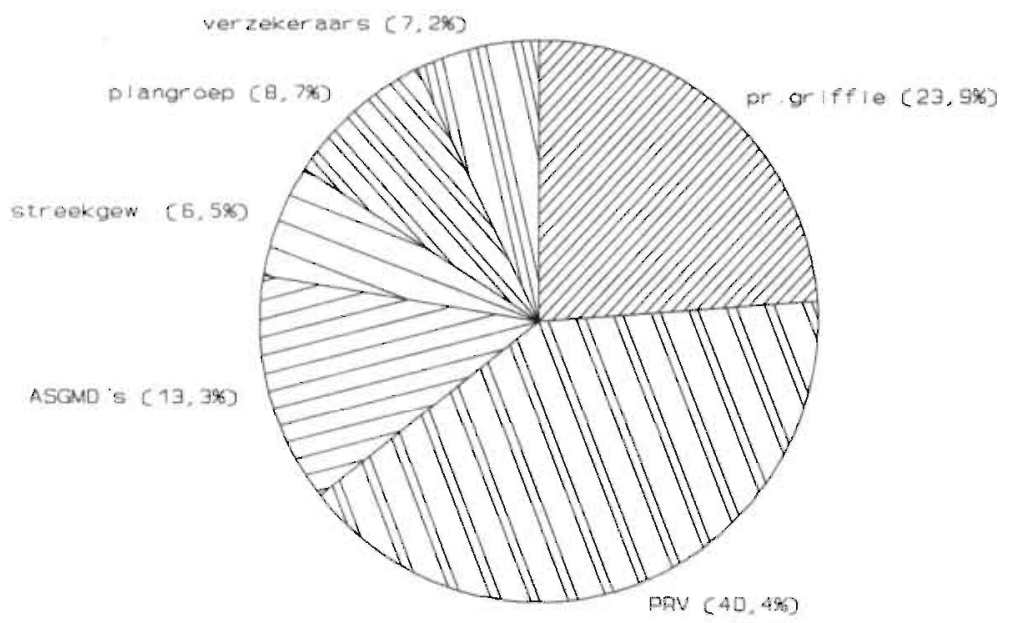

\section{§ 7.4 Evaluatie van de meting van de bestuurskosten van artikel 4}

In deze paragraaf zal worden ingegaan op de methodologische voorwaarden, zoals deze in hoofdstuk 4 zijn gesteld.

De validiteit betreft de vraag of men meet wat men wil meten. Dit betekent dat de meting van de bestede tijd inderdaad de bestuurskosten weergeeft. Hierover kan worden opgemerkt dat alleen al het beschrijven en het volgen van alle activiteiten die voortvloeien uit het uitvoeren van bestuurlijke maatregelen een goede indruk geven van hetgeen een maatregel aan "bestuurlijke drukte" teweeg kan brengen. Niet alleen komen op deze manier de verschillen tussen de theorie van de wettekst en de praktijk van de uitvoering duidelijk naar voren. Ook de implicaties van een op papier misschien eenvoudig lijkende operatie, maar in de praktijk tamelijk ingewikkelde en veel omvattende procedure, worden evident. Daarnaast geeft de beschrijving van aan de maatregel gerelateerde regelingen een indruk van de grote onrust waardoor de wetgeving op het gebied van de planning gekenmerkt kan worden.

Verder kan ten aanzien van de validiteit worden opgemerkt dat hier sprake is van de meest direct mogelijke meting van de bestuurskosten. Voor de meting zijn uitsluitend de direct betrokken uitvoerders benaderd. Bovendien zijn van deze direct betrokkenen uitsluitend de directe werkzaamheden ten behoeve van de planning meegerekend. De berekende tijdsduur geeft dan ook de minimaal bestede tijd weer. Dit betekent dat sprake is van een conservatieve schatting. 
De betrouwbaarheid betreft de respondenten. De inventarisatie is in hoge mate afhankelijk van de respondenten. De meeste ondervraagden gaverı aan moeite te hebben met het inschatten van de tijd die zij hadden besteed aan bepaalde activiteiten. Met het volgende moet dan ook rekening gehouden worden:

- het is hoe dan ook moeilijk om een juiste inschatting te maken van cle tijdsbesteding;

- activiteiten zijn lastig af te baken door overlap met of overgaan in andere activiteiten;

activiteiten vonden soms een jaar of nog langer geleden plaats;

- zoals reeds aangegeven betreft de inventarisatie slechts een deel van alle directe activiteiten (wat te denken van telefonisch en ander informeel overleg?) en geen indirecte activiteiten (secretariaatswerkzaamheden, drukwerk). Dit betekent dat het slechts een conservatieve schatting betreft.

Bovendien beklemtoonden de respondenten veelvuldig dat het ging om grove schattingen. Daarbij aansluitend kan voor wat de vijf Samenwerkingsverbanden van instellingen in de gezondheidszorg aangaat, geen uitspraak gedaan worden omtrent de tijd die de medewerkers van de bureaus hebben besteed aan de afzonderlijke werkzaamheden met betrekking tot de totstandkoming van het plan. Wel is de in totaal hieraan bestede tijd meegenomen in het eindoverzicht.

Het grote voordeel verbonden aan het hanteren van de uitvoering van een maatregel als indicatie voor de bestuurskosten van deze methode is dat bij de meting en de beschrijving alle relevant geachte personen en schriftelijke stukken kunnen worden geraadpleegd. Dit bevordert de volledigheid. Met het oog op de betrouwbaarheid heeft een systematische beschrijving van de meting plaatsgevonden.

Generalisatie is hier niet aan de orde. Het was de bedoeling te laten zien dat het mogelijk is de bestuurskosten te meten aan de hand van de tijdsbesteding van de betrokkenen. Afgezien daarvan zou het totale aantal geschatte mensuren niet gegeneraliseerd kunnen worden naar andere regio's. De reden hiervoor is gelegen in het feit dat iedere regio een eigen planprocedure heeft ontworpen. De ene procedure is meer uitgebreid, met commissies, inspraakronden, dan de andere. Bovendien zijn de omstandigheden in iedere regio en zelfs binnen de regio's per soort voorzieningen (verpleeghuizen, ziekenhuizen en dergelijke) verschillend. Het zal bijvoorbeeld ongetwijfeld meer tijd kosten om overeenstemming te bereiken in een regio of met betrekking tot voorzieningen wanneer sprake is van uitbreiding, dan wanneer bedden moeten worden ingeleverd. Men zou verder bezwaar kunnen maken tegen het feit dat uitgerekend voor de provincie Limburg de benodigde tijd is geinventariseerd, aangezien juist daar de Wet Voorzieningen Gezondheidszorg naast de Wet Ziekenhuisvoorzieningen is toegepast.

Kortom, het inventariseren van de benodigde tijd is een bruikbare aanvulling op het beschrijvende gedeelte, wanneer men de geplaatste kanttekeningen incalculeert. Het beschrijvende deel geeft een goede indruk van de hoogte van de bestuurskosten, terwiji het gekwantificeerde deel concreter materiaal oplevert. Het meten van de bestuurskosten aan de hand van een dergelijke inventarisatie lijkt een goede indruk te geven van de benodigde bestuurskosten bij de uitvoering van artikel 4 . 


\section{§ 7.5 Samenvatting en conclusies}

In dit hoofdstuk is getracht de bestuurskosten te meten aan de hand van de tijd die is besteed aan de uitvoering van artikel 4 van de Wet Ziekenhuisvoorzieningen.

De wettekst van de Wet Ziekenhuisvoorzieningen schrijtt voor dat de provincie van de staatssecretaris een aanwijzing en richtlijnen ontvangt omtrent de op te stellen plannen. Hierna stelt de provincie een voorontwerpplan op. Naar aanleiding van dit voorontwerpplan kunnen betrokken instellingen, die bezwaren hebben tegen het ontwerp, deelnemen aan de inspraakronde. Wanneer hiervan een verslag is gemaakt, gaat het ontwerp voor advies naar het College voor Ziekenhuisvoorzieningen en tenslotte voor vaststelling naar de staatssecretaris.

In de provincie Limburg is de procedure volgens de Wet Ziekenhuisvoorzieningen gecombineerd met de procedure op grond van de Wet Voorzieningen Gezondheidszorg. Dit heeft tot gevolg dat de betrokken instellingen nauwer bij de totstandkoming van de ontwerpplannen zijn betrokken en dat de verpleeghuisplannen zijn uitgebreid tot plannen voor de langerdurende gezondheidszorg. De procedure was als volgt

De Provinciale Raad voor de Volksgezondheid krijgt de opdracht een inventarisatie te maken van de reeds aanwezige voorzieningen. Gedeputeerde Staten stellen vervolgens een ontwerp-beleidsvisie op, dat voor advies aan de Provinciale Raad voor de Volksgezondheid, de samenwerkingsverbanden van instellingen, de gemeenten en de ziekenfondsen wordt gezonden. Daarna volgt vaststelling door Provinciale Staten. Hierna krijgt de Provinciale Raad voor de Volksgezondheid de opdracht de voorontwerpen op te stellen. De Raad voert hieromtrent vooroverleg met de samenwerkingsverbanden en de ziekenfondsen. Na goedkeuring stellen Gedeputeerde Staten de voorontwerpen vast en worden zij tervisie gelegd voor de bezwarenronde. Provinciale Staten beoordelen de bezwaren, nemen ze eventueel op in de ontwerpen en stellen deze tenslotte vast.

Voordat deze laatste stappen gezet kunnen worden neemt de regering een gedeelte van de aanbevelingen van de commissie-Dekker over. Dit betekent dat het voorontwerp in globalere termen geformuleerd moet worden en dus opnieuw geschreven.

De bestuurskosten van artikel 4 zijn bepaald aan de hand van de bestede tijd. Hieronder wordt verstaan de tijd die directe uitvoerders hebben besteed aan de totstandkoming van het verpleeghuisplan.

In totaal zijn met de opstelling van het ontwerpplan 731 directe full time dagen gemoeid. Hiertoe is de directe tijd van iedereen, die direct bij de opstelling betrokken was, meegerekend. Indirecte, maar wel gerelateerde activiteiten, zoals overleg met de achterban, werkbezoeken bij instellingen zijn niet meegerekend; evenmin als alle indirecte activiteiten van secretariaten, archiefzaken, de drukkerij.

Het probleem van de validiteit is benaderd door zoveel mogelijk alle activiteiten en personen die deze activiteiten uitvoeren mee te nemen in het onderzoek. Afbreuk aan de betrouwbaarheid doet de meting aan de hand van schattingen van direct betrokkenen. Desalniettemin lijken zowel het beschrijvende als het kwantitatieve deel van de inventarisatie van de maatregel een indruk te geven van de bestuurskosten die het gevolg zijn van een maatregel. Op deze manier komt tot uitdrukking welke activiteiten werkelijk ondernomen worden wanneer een maatregel in de praktijk wordt uitgevoerd, wie en hoeveel personen bij de uitvoering betrokken zijn en hoeveel de uitvoering van een maatregel gekost heeft. Het verschil tussen de theorie van de wettekst en de praktijk van de uitvoering komt duidelijk naar voren. 


\section{Hoofdstuk 8}

\section{CONCLUSIES}

\section{\$8.1 Inleiding}

Het doel van dit hoofdstuk is nog eens kort weer te geven wat de belangrijkste uitkomsten van deze studie zijn, hoe de probleemstelling kan worden beantwoord en wat in de praktijk met deze resultaten kan worden gedaan.

De bedoeling van deze studie was na te gaan hoe bestuurskosten kunnen worden gemeten. Hierbij is de volgende definitie uitgangspunt: bestuurskosten zijn de kosten van de bestuurlijke infrastructuur bij overheden en particulieren die het gevolg zijn van overheidsbesturing in de gezondheidszorg.

In deze studie zijn de bestuurskosten uitgangspunt geweest. Deze zijn voor een deel het gevolg van overheidsbesturing in de gezondheidszorg. Aangezien de overheidsbesturing almaar toeneemt, groeien ook de bestuurskosten. In de politiek wordt te weinig rekening gehouden met de bestuurskosten. Daardoor moeten de bestuurskosten eerst zichtbaar worden gemaakt. Dit is een probleem, want bestuurskosten zijn moeilijk te meten. Bij de meting stuit men immers op de nodige betrouwbaarheids- en validiteitsproblemen. Waarschijnlijk is dat de reden waarom de bestuurskosten nog nauwelijks zijn gemeten. In deze studie wordt hiertoe wel een poging gedaan.

In dit hoofdstuk komt het volgende aan de orde. In paragraal 8.2 worden de probleemstelling en de onderzoeksvragen van deze studie beantwoord. In paragraaf 8.3 worden de belangrijkste conclusies nogmaals kort weergegeven. Tenslotte komen in paragraaf 8.4 de mogelijke beleidsimplicaties van de resultaten van deze studie aan de orde. 


\section{§ 8.2 De probleemstelling beantwoord}

De probleemstelling van dit onderzoek luidde als volgt: hoe kan de omvang van de bestuurskosten in de gezondheidszorg worden gemeten? Om antwoord te kunnen geven op deze vraag is deze studie toegespitst op de beantwoording van een aantal onderzoeksvragen.

De eerste vraag betrof de omschrijving van het begrip bestuurskosten. Aan de hand van een verrichte literatuurstudie konden de volgende kenmerken van bestuurskosten worden onderscheiden: bestuurskosten zijn al dan niet het gevolg van overheidsbesturing; bestuurskosten zijn verborgen op begrotingen; de dragers van bestuurskosten zijn overheden, particulieren of beide; investeringen en voorzieningen worden in het algemeen niet tot de bestuurskosten gerekend; bestuurskosten worden ingedeeld naar onderdelen van een beleidsproces; bestuurskosten kunnen empirisch of normatief worden benaderd. Aangezien in deze publicaties, enkele uitgezonderd, de bestuurskosten alleen worden omschreven, maar niet gekwantificeerd, bleek voor deze studie een eigen definitie noodzakelijk. De volgende definitie is gehanteerd: bestuurskosten zijn de kosten van de bestuurlijke infrastructuur bij overheden en particulieren die het gevolg zijn van overheidsbesturing in de gezondheidszorg. Dit is een enge benadering van bestuurskosten. In de brede benadering behelzen bestuurskosten tevens de kosten van de interne besturing van instellingen en van zelfregulering van instellingen onderling. Deze staan los van overheidsbesturing.

De tweede vraag betrof de oorzaak van de stijging van de bestuurskosten. De oorzaak van de stijging van de bestuurskosten is voor een deel te verklaren uit de toename van overheidsbesturing in de gezondheidszorg. Waardoor de overheidsbesturing is toegenomen, is in de eerste plaats een gevolg van de stijging van de overheidsbesturing op alle terreinen van het maatschappelijk leven. In de tweede plaats is met name in de gezondheidszorg de overheidsbesturing alsmaar toegenomen. De overheidsbesturing is in gang gezet door de Wet op het Staatstoezicht uit 1965 en sindsdien is het aantal overheidsregelingen danig toegenomen. Met name sinds het verschijnen van de Structuurnota in 1974 is de overheidsbesturing in de gezondheidszorg aanzienlijk gegroeid, getuige de stijging van het aantal en het bereik van wetten.

De overheid staat voor de besturing een aantal besturingsinstrumenten ter beschikking: wetgeving, prikkels, voorzieningen en informatie. Vooral in de jaren zeventig en tachtig heeft de overheid de gezondheidszorg veelvuldig met het instrument wetgeving gestuurd. Bij de uitvoering van de wetgeving maken de uitvoerders hiervan, zowel overheden, als particuliere gezondheidszorginstanties, bestuurskosten.

De derde kwestie betrof de vraag of bestuurskosten als zodanig zijn terug te vinden op begrotingen. Op de rijksbegroting zijn bestuurskosten niet terug te vinden. Doordat de rijksbegroting is gebaseerd op het kasstelsel wordt een indeling naar inkomsten en uitgaven gehanteerd. Informatie over kosten ontbreekt daardoor, ondanks dat formeel sedert enkele jaren het gebruik van de prestatiebegroting wordt geadviseerd. De provincie- en de gemeentebegroting zijn weliswaar gebaseerd op het stelsel van baten en lasten, maar de bestuurskosten zijn daar niet uit at te leiden.

De vierde vraag had betrekking op de afbakening. Afbakening van de bestuurskosten in de gezondheidszorg is een problematische bezigheid gebleken. Hiervoor zijn tal van oorzaken te noemen. De gezondheidszorgsector is in de loop der jaren 
met de maatschappelijke dienstverlening uitgebreid tot de zorgsector. Een eenduidige begrenzing is dan ook moeilijk te geven. Er is geen duidelijke grens aan te geven tussen beleidsvorming en beleidsuitvoering. Het aantal actoren dat bij beleid is betrokken, is groot en heeft de neiging uit te dijen. De grens tussen de uitvoering van overheidsmaatregelen en de interne beleidsvoering binnen instellingen is moeilijk te trekken. Hoe lager het meetniveau des te problematischer wordt de afbakening. Niet alle activiteiten zijn even gemakkelijk af te bakenen.

De vijfde vraag betrof de mogelijke methoden om bestuurskosten te meten. De meting van de bestuurskosten kan op diverse manieren plaatsvinden. Bestuurskosten kan men meten door verschillende secundaire data te verzamelen. Verder kan men deze meten door onderzoekers te laten registreren, door betrokkenen zelf te laten registreren, doordat de onderzoeker betrokkenen in interviews laat schatten of door de doorlooptijd te inventariseren. Om na te kunnen gaan welke methode geschikt is, is in deze studie gekozen voor verschillende methoden. Om de bestuurskosten te meten zijn secundaire gegevens geïnterpreteerd met als uitgangspunt het hoofdstuk "kosten van beleid, administratie en beheer" van het Financieel Overzicht. Teneinde te komen tot de bestuurskosten zijn aanvullende gegevens zijn verzameld uit publicaties van het Centraal Bureau voor de Statistiek, het Nationaal Ziekenhuisinstituut en uit jaarverslagen van diverse instanties. Verder is de doorlooptijd van artikel 18 van de Wet Ziekenhuisvoorzieningen en de tijd besteed aan artikel 4 van de Wet Ziekenhuisvoorzieningen bepaald. De doorlooptijd is de tijd die verstrijkt tussen het begin en het einde van een bepaalde maatregel. De bestede tijd is de tijd die direct betrokkenen kwijt zijn bij de uitvoering van een bepaalde maatregel.

Het antwoord op de zevende vraag, wat is de omvang van de bestuurskosten, is gerelateerd aan de drie methoden waarmee de bestuurskosten zijn gemeten. Hiermee wordt tevens de zesde onderzoeksvraag naar de gehanteerde meetmethode beantwoord. De omvang van de bestuurskosten is bepaald met het cijfermateriaal uit het Financieel Overzicht als uitgangspunt. Het Financieel Overzicht wordt ieder jaar als bijlage bij de begroting van het ministerie van Welzijn, Volksgezondheid en Cultuur gevoegd. Het hoofdstuk "kosten van beleid, administratie en beheer" biedt uitsluitend inzicht in de bestuurskosten bij overheden, verzekeraars en adviesorganen. In absolute aantallen zijn de kosten van beleid, administratie en beheer gestegen van $f 425$ miljoen in 1977 tot $f 1.863$ miljoen in 1988 . De kosten van de sector beleid, administratie en beheer zijn sinds de jaren zeventig ruim verviervoudigd. Sedert het begin van de jaren tachtig kan men een afvlakking constateren. Het grootste deel van de kosten van beleid, administratie en beheer komt voor rekening van de verzekeraars. Wat hierbij opvalt is dat de beheerskosten per particulier verzekerde bijna het dubbele bedraagt als de beheerskosten per ziekentondsverzekerde.

Volgens het Financieel Overzicht beslaan de kosten van beleid, administratie en beheer bijna vijf procent van de totale kosten van de zorgsector. Aanvulling met secundaire gegevens, zodat de hoogte van de bestuurskosten, inclusief de bestuurskosten van particulieren, duidelijk wordt, levert een percentage op van maximaal bijna twaalf procent van de totale kosten van de zorgsector. Hierbij zijn alle indirecte kosten van instellingen in de gezondheidszorg meegerekend, hetgeen een brede benadering van bestuurskosten impliceert. Uitgedrukt in aantallen formatieplaatsen luidde de conclusie dat per drie directe werkers in de gezondheidszorg één indirecte werker actief is. Met andere woorden: de "medical B-factor" bedraagt 0,3 .

De omvang van de bestuurskosten uitgedrukt in doorlooptijd is geinventariseerd aan de hand van de uitvoering van artikel 18 van de Wet Ziekenhuisvoorzieningen. 
De bestuurskosten uitgedrukt in de doorlooptijd geven een indruk van de tijd die het de overheid kost om regels op te stellen en uit te voeren en van de tijd die het instellingen kost om deze regels na te leven. Krachtens artike 18 diende iedere instellingen voor de aanschaf en het gebruik van bepaalde topklinische voorzieningen te beschikken over een vergunning. De staatssecretaris bepaalde welke voorzieningen onder artikel 18 zouden worden geplaatst. Vervolgens legde hij in planningsbesluiten vast hoe groot de behoefte aan de betreffende voorzieningen was en in welke ziekenhuizen men deze mocht aanschaffen. In deze studie is ten eerste de doorlooptijd van de totstandkoming van deze planningsbesluiten bepaald en ten tweede de doorlooptijd van het aanvragen van vergunningen door ziekenhuizen. De doorlooptijd van de totstandkoming van de planningsbesluiten is berekend aan de hand van de tijdstippen waarop de besluiten, de concept-planningsbesluiten en de planningsbesluiten zijn gedateerd. De doorlooptijd van de vergunningaanvragen door Limburgse ziekenhuizen is bepaald aan de hand van gegevens verstrekt door directiesecretariaten en door eigen archiefonderzoek. Uitgangspunten hierbij waren de data, zoals vermeld op de schriftelijke aanvragen en op de reacties van het ministerie. Deze inventarisatie leverde het volgende op. De bestuurskosten uitgedrukt in doorlooptijd lag voor de planningsbesluiten tussen ruim twee jaar tot ruim 13 jaar. De doorlooptijd van vergunningaanvragen in de provincie Limburg varieerde van één jaar tot vijf jaar.

De omvang van de bestuurskosten uitgedrukt in bestede tijd is geïnventariseerd aan de hand van de uitvoering van artikel 4 van de Wet Ziekenhuisvoorzieningen. De bestuurskosten uitgedrukt in de bestede tijd geven een indruk van de tijd die het uitvoerders van maatregelen, zowel overheden, als instellingen, als ook verzekeraars, kost om de betreffende maatregelen en de daaruit voortvloeiende procedures na te leven. Krachtens artikel 4 diende iedere provincie te beschikken over plannen voor drie sectoren, namelijk voor ziekenhuizen, verpleeghuizen en psychiatrische ziekenhuizen. De opstelling van deze plannen was aan regels onderhevig. In deze studie is berekend hoeveel tijd de afzonderlijke directe medewerkers van diverse instanties hebben besteed aan de totstandkoming van het verpleeghuisplan in de provincie Limburg. Dit is gebeurd door bij alle direct betrokkenen hiernaar te informeren. Deze inventarisatie leverde het volgende op: de direct bestede tijd aan de totstandkoming van het verpleeghuisplan in de provincie Limburg bedroeg 731 full time dagen.

De laatste onderzoeksvraag ging in op de geschiktheid van de gehanteerde meetmethoden om de bestuurskosten in de gezondheidszorg te bepalen. Om hierop antwoord te kunnen geven, zal nogmaals worden ingegaan op de kanttekeningen betreffende de metingen. Voor de weergave van de bestuurskosten van de gehele sector is uitgegaan van bestaande gegevens uit het Financieel Overzicht. In hoeverre deze betrouwbaar zijn, is afhankelijk van de in het Financieel Overzicht gehanteerde bronnen en de wijze van gegevensverzameling. Een pluspunt is dat in veel gevallen de gegevens afkomstig zijn van goedgekeurde jaarrekeningen en begrotingen. Het blijft echter de vraag hoe bijvoorbeeld de beheerskosten van overheden en particuliere verzekeraars zijn berekend. Voor de weergave van de bestuurskosten is gebruik gemaakt van cijfermateriaal van het Centraal Bureau voor de Statistiek en het Nationaal Ziekenhuisinstituut. Hoewel deze instanties onderscheid maken tussen directe werkers, dat wil zeggen artsen, verpleegkundigen, en indirecte werkers, dat wil zeggen directieleden en stafmedewerkers, is onbedoeld sprake van een brede benadering van de bestuurskosten. Hiertoe behoren immers de bestuurskosten van directe werkers die indirecte werkzaamheden verrichten, zoals werkoverleg, roosterplanning en de bestuurskosten van de beleidsmatige activiteiten van indirecte werkers. Deze kosten zijn inherent aan het adequaat laten functioneren van een instelling en onafhankelijk is van besturings- 
maatregelen van buiten. Deze kosten kunnen niet worden uitgesloten. Is men van mening dat de bepaling van de bestuurskosten, zoals hierboven beschreven, op teveel bezwaren stuit, is de enige andere optie dat men de bestuurskosten zelf inventariseert aan de hand van de directe registratie door individuele werkers. Met het oog hierop luidde de conclusie van deze studie dat de gehanteerde methoden om de bestuurskosten te meten hiertoe geschikt zijn.

Om te bepalen of de meting van de bestuurskosten uitgedrukt in de doorlooptijd een geschikte methode is, dient men zich een aantal zaken te realiseren. In de eerste plaats kan sprake zijn van onderschatting van de feitelijke doorlooptijd doordat reeds voor de formele afkondiging van de besluiten, tijdelijke regelingen en voor de indiening van de aanvragen aan de totstandkoming ervan is gewerkt. Overschatting van de doorlooptijd vindt plaats doordat gedurende de tijd dat een vergunningaanvraag in behandeling is, geen sprake hoeft te zijn van daadwerkelijke activiteiten die tijd en geld kosten. Het ligt voor de hand dat de aanvragen voor een groot gedeelte van de tijd liggen te wachten op besluitvorming. Hiertegenover staat dat veel meetpunten waarop de begin- en eindtijden zijn gebaseerd, op papier vast liggen, zodat deze kunnen worden gecontroleerd. Daarbij komt dat deze methode die de doorlooptijd bepaald, eenvoudig is uit te voeren en weinig tijd kost. Deze argumenten tegen elkaar afwegend luidde de conclusie dat de bepaling van de bestuurskosten aan de hand van de doorlooptijd een geschikte methode is om de bestuurskosten in de gezondheidszorg te meten.

Om vast te stellen of de bepaling van de bestuurskosten in de vorm van de bestede tijd een geschikte methode is om de bestuurskosten te inventariseren, dient men rekening te houden met het volgende. De bepaling van de bestuurskosten aan de hand van de direct bestede tijd is de meest rechtstreekse manier om deze kosten te meten. De nadelen van de andere twee methoden, over- of onderschatting doordat gegevensverzameling indirect of op een hoger niveau plaatsvindt, spelen hier geen rol. Er zijn echter ook nadelen verbonden aan een dergelijke directe manier van gegevensverzameling, namelijk van de direct uitvoerenden. Immers, doordat alleen de tijd van de direct betrokkenen is meegerekend, is sprake van schatting van de minimaal bestede tijd. Daarnaast bestaat altijd een zekere weerstand bij betrokkenen tegen het aangeven van de bestede tijd. Bovendien is het lastig een juiste inschatting te geven van de bestede tijd. Een ander nadeel is het feit dat deze methode tijdrovend is voor alle betrokkenen. Hiertegenover staat dat men de gemiddeld bestede tijd kan bepalen wanneer een aantal personen vergelijkbare activiteiten ondernemen. Verder biedt een dergelijk uitgebreide inventarisatie een goed inzicht in de activiteiten en werkzaamheden die gepaard gaan met de uitvoering van een maatregel. De conclusie van deze studie luidde dat indien een beleidsmaker is geïnteresseerd in de werkelijk bestede tijd van de uitvoering van een maatregel, deze methode geschikt is om hierin inzicht te bieden. Hij moet zich echter rekenschap geven van de beperkingen.

\section{§ 8.3 Eindconclusies}

Uit deze studie is gebleken dat nog weinig onderzoek is verricht naar de bestuurskosten in de gezondheidszorg. Met name pogingen om de bestuurskosten in kwantitatieve termen te inventariseren ontbreken nagenoeg volledig. In de meeste publicaties heeft men zich beperkt tot omschrijvingen van het begrip "bestuurskosten". Publicaties met betrekking tot omschrijving van het begrip "bestuurskosten" zijn dan ook aanzienlijk minder schaars. Hetgeen hieraan echter opviel was het feit dat de omschrijvingen dusdanig verschillen dat zelfs deze omschrijvingen niet geschikt waren om als definitie te worden gehanteerd voor kwantitatief onderzoek. 
Een bijkomend probleem was het feit dat wanneer al cijfermateriaal voorhanden was, niet duidelijk was of dit zonder meer bij elkaar kon worden opgeteld. Er kan dan bijvoorbeeld sprake zijn van dubbeltellingen of van hiaten.

De eigen inventarisatie heeft geleerd dat omschrijving en afbakening van het begrip "bestuurskosten" problematisch is. Het is moeilijk eenduidig aan te geven welke activiteiten wel of niet tot bestuurskosten leiden en welke actoren al dan niet bestuurskosten genereren. Het is dan wel mogelijk keuzes te maken over wat en wie wel of niet meetelt, maar vaak bepalen deze keuzes dan tevens de hoogte van de bestuurskosten. Wil men echter een poging doen tot kwantificering van bestuurskosten, dan is dit echter een noodzakelijk kwaad.

Ten tijde van deze studie kon een duidelijke relatie worden gelegd tussen de bestuurskosten en de recente ontwikkelingen in het gezondheidszorgbeleid. Niet alleen de invoering van de Wet Voorzieningen Gezondheidszorg, maar ook de plannen van staatssecretaris Simons hadden en hebben invloed op de bestuurskosten in de gezondheidszorg. Ten aanzien van de Wet Voorzieningen Gezondheidszorg, en dit geldt ook voor de Wet Ziekenhuisvoorzieningen, kan men stellen dat de uitgebreide procedures om te komen tot plannen en vergunningen bij zowel overheden als particulieren leiden tot bestuurskosten. En dan is niet zozeer bepalend dat de totstandkoming van plannen en het aanvragen van vergunningen verplicht is, als wel de manier waarop deze regels moeten worden nageleefd. In beide gevallen dienen immers uitgebreide procedurevoorschriften te worden uitgevoerd. Met name de uitvoering hiervan brengt bestuurskosten met zich.

Bij de voorgestelde stelselwijziging volgens het plan Simons is sprake van een tendens, die slechts een verschuiving van de bestuurskosten betekent. Het planSimons beoogt immers terugdringing van de overheidsbesturing ten gunste van besturing door de particulieren in de gezondheidszorg. Hoewel hierdoor de noodzaak van het opstellen van plannen en het verlenen van vergunningen door overheden geringer wordt, zijn het in de toekomst de deeinemers aan de gezondheidszorgmarkt die dit onderling moeten regelen. Dit zal er bijvoorbeeld toe leiden dat alle zorgverzekeraars afspraken en contracten dienen te maken met alle afzonderlijke instellingen en individuele zorgverleners, met alle bestuurskosten (overigens in brede zin) van dien. Dit is onder meer de verwachting en calculatie van de Ziekenfondsraad. De Ziekenfondsraad schat dat de kosten van de uitvoering van de stelselwijziging uiteindelijk met $f 250$ miljoen zullen stijgen. In de Verenigde Staten laat de praktijk zien dat deze verwachting niet uit de lucht is gegrepen.

Worden toch afspraken gemaakt om een en ander collectief te regelen, dan nog zal dit gepaard gaan met aanzienlijke bestuurskosten. Men denke aan de kosten van het afsluiten van contracten. Bovendien heeft de beoogde stelselwijziging dan slechts tot gevolg dat niet langer voornamelijk de overheid bestuurskosten genereert, maar dat deze zullen worden verrekend in de premies van de ziektekostenverzekeringen. De hoogte van de bestuurskosten wordt er niet door beïnvloed.

\section{§8.4 Beleidsimplicaties}

Gezien de gebleken omvang van de bestuurskosten in de gezondheidszorg, zouden deze vaker moeten worden geïnventariseerd. De hoogte en de verdeling van de bestuurskosten zouden een sterkere rol moeten spelen bij de besluitvorming omtrent de invoering van bepaalde maatregelen. Wellicht zouden bepaalde 
maatregelen reeds in een eerder stadium afvallen, omdat de uitvoering kostbaarder is dan de verwachte effecten.

Bij voorkeur zou van tevoren reeds inzicht moeten bestaan in de geschatte bestuurskosten van een maatregel. De Ziekenfondsraad laat zien dat tenminste in bepaalde gevallen verwachte kosten van beoogde maatregelen kunnen worden becijferd. Verder zou men van tevoren moeten afspreken hoe hoog de kosten van de uitvoering mogen zijn ten opzichte van de verwachte baten. Wanneer een maatregel in de uitvoering al zoveel kost dat de opbrengsten of besparingen hier nooit tegen kunnen opwegen, zou men zich moeten afvragen of de invoering van een dergelijke maatregel nog wel verantwoord is.

De hoogte van de bestuurskosten zou een rol moeten spelen bij de afweging tussen het al dan niet doorvoeren van deregulering of decentralisering. Wanneer het de bedoeling is dat aan de eindsituatie niets verandert, indien bijvoorbeeld voor iedereen gezondheidszorgvoorzieningen financieel toegankelijk moeten blijven, leidt deregulering alleen tot verschuiving van de bestuurskosten van de publieke naar de private sector. De bestuurskosten worden zeer zeker niet minder, misschien eerder meer. Dit geldt eveneens voor decentralisatie: indien taken worden afgeschoven op lagere overheden, wordt de omvang van de bestuurskosten eerder groter dan kleiner. Identieke taken worden dan uitgevoerd door lagere overheden en de rijksoverheid krijgt er een controlerende functie bij.

Het is des te opvallender dat in tijden waarin de directe patiëntenzorg met zoveel financiële problemen kampt, de kosten in de indirecte sfeer zozeer kunnen stijgen en naar verwachting zullen blijven stijgen. In de voorgestelde stelselwijziging zullen vele partijen contracten en accoorden moeten afsluiten en is sprake van meer uitvoeringsorganen. Met het oog hierop zullen de bestuurskosten naar verwachting toenemen. Reeds nu zijn de bestuurskosten per particulier verzekerde hoger dan de bestuurskosten per ziekenfondsverzekerde. Aangezien het verzekeringsstelsel meer private trekken dient te krijgen, ligt stijging van de bestuurskosten in de lijn der verwachting. Ook dit is een reden om de hoogte van de bestuurskosten scherp in de gaten te houden.

Toekomstig onderzoek naar bestuurskosten lijkt alleszins de moeite waard. De gehanteerde dataverzamelingsmethoden bieden in ieder geval enige indicatie van de hoogte van de bestuurskosten. 



\section{SAMENVATTING}

De besturing van de gezondheidszorg door de overheid is steeds toegenomen. Als gevolg daarvan zijn ook de bestuurskosten blijven stijgen. De bestuurskosten zijn niet de kosten van de directe zorgverlening, maar de kosten van de bestuurlijke infrastructuur. Dit vermoeden is echter nooit met cijfermateriaal onderbouwd. Het doel van deze studie is dan ook een aanzet te geven tot de inventarisatie en kwantificering van de bestuurskosten in de gezondheidszorg.

Bestuurskosten zijn het gevolg van overheidsbesturing. Hiertoe staat de overheid een viertal instrumenten ter beschikking. Dit zijn wetgeving, prikkels, voorzieningen en informatie. Ten aanzien van de gezondheidszorg lijken wetten vaakst te worden gehanteerd.

Om het inzicht in de bestuurskosten te vergroten is naar aanknopingspunten gezocht in de economie. De nieuwe institutionele economie blijkt het beste aan te sluiten. Tot de nieuwe institutionele economie behoort onder meer de transactiekostenbenadering. Volgens de transactiekostenbenadering zijn regels op te vatten als transacties en worden bij de naleving bestuurskosten gemaakt

Verder is sprake van grote begripsmatige onduidelijkheid. In iedere publicatie worden andere benamingen en definities gehanteerd. Voorbeelden van benamingen zijn beleidskosten, plankosten en bureaucratiekosten. Op grond van een aantal gemeenschappelijke kenmerken is voor de volgende definitie gekozen: bestuurskosten zijn de kosten van de bestuurlijke infrastructuur bij overheden en particulieren die het gevolg zijn van overheidsbesturing. In deze studie wordt uitgegaan van de enge benadering van bestuurskosten, zodanig dat alleen de kosten bij overheden en particulieren worden meegerekend voorzover zij het gevolg zijn van overheidsbesturing. Bestuurskosten in brede zin bestaan daarnaast uit de kosten die instellingen maken als gevolg van de interne besturing en als gevolg van het naleven van onderlinge afspraken tussen instellingen.

Inventarisatie van bestuurskosten zou geen probleem zijn wanneer bestuurskosten een aparte post zou vormen op begrotingen. De rijks-, provincie- en gemeentebegrotingen zijn echter ingedeeld naar inkomsten en uitgaven. Zij geven geen inzicht in kosten en baten en dus ook niet in bestuurskosten. Door de recente invoering van de prestatiebegroting zou hier in de toekomst verandering in kunnen komen. Een opgesteld plan of een verleende vergunning kan immers als een prestatie worden aangemerkt. Vooralsnog wordt de prestatiebegroting echter niet op grote schaal toegepast. Ook de jaarrekeningen van instellingen hanteren de post "bestuurskosten" niet. is men dus geïnteresseerd in de hoogte van de bestuurskosten, dan is men genoodzaakt de bestuurskosten zelf te meten. Dit is hier dan ook getracht. Aangezien het niet gebruikelijk is om bestuurskosten te meten. bestaat ook geen vaste methode om dit te doen. In deze studie zijn dan ook diverse methoden uitgeprobeerd om bestuurskosten te kwantificeren. Dit is als volgt gebeurd.

De eerste werkwijze om de bestuurskosten te meten vindt plaats aan de hand van het hoofdstuk "kosten van beleid, administratie en beheer" van het Financieel Overzicht. Het Financieel Overzicht is een bijlage bij de begroting van het ministerie van Welzijn, Volksgezondheid en Cultuur. Het bevat gegevens omtrent volume en kosten van gezondheidszorgvoorzieningen en vormt tevens een macro-budget voor de totale gezondheidszorg. Het Financieel Overzicht is tegenwoordig ingedeeld naar soorten voorzieningen, zoals ziekenhuizen en voorzieningen voor ouderen. Daarnaast bevat het Overzicht een hoofdstuk "kosten van beleid, 
administratie en beheer". Hiertoe worden gerekend de kosten van de overheden, verzekeraars en adviesorganen. Uitgaande van de definitie van bestuurskosten is dit kostenoverzicht echter niet compleet. Ook instellingen, individuele beroepsbeoefenaren en andere directe werkers in de gezondheidszorg maken immers bestuurskosten. Om het hootdstuk "kosten van beleid, administratie en beheer" te completeren zijn aanvullingen gezocht aan de hand van statistieken van het Centraal Bureau voor de Statistiek en het Nationaal Ziekenhuisinstituut. Het nadeel hiervan is dat deze aanvullingen een zekere hoeveelheid ruis bevatten. Deze kosten zijn namelijk inclusief bijvoorbeeld de kosten van intern overleg, die natuurlijk niet het gevolg zijn van overheidsbesturing. Mel deze kanttekening heeft de gegevensverzameling het volgende opgeleverd. De bestuurskosten volgens het Financieel Overzicht (de kosten van beleid, administratie en beheer) vormen bijna vijf procent van de totale kosten van de zorgsector. De bestuurskosten maken maximaal twaalf procent uit van de totale kosten. Uitgedrukt in het aantal formatieplaatsen betekent dit dat de zorgsector per drie directe zorgverleners één indirecte medewerker telt.

De tweede benadering om de bestuurskosten te bepalen vormt de inventarisatie van de doorlooptijd van de opstelling van planningsbesluiten en van de afhandeling van vergunningaanvragen op grond van artikel 18 van de Wet Ziekenhuisvoorzieningen. De doorlooptijd is de tijd die verstrijkt tussen het begin en het einde van een procedure. Artikel 18 betreft kostbare apparatuur of behandelingen die een zeer specifieke kennis vereisen. Zij worden ook "bijzondere voorzieningen" genoemd. Voorbeelden zijn hartchirurgie of In Vitro Fertilisatie. Planningsbesluiten geven aan welke instellingen welke artikel 18-voorzieningen mogen verstrekken. De doorlooptijd van de totstandkoming van de planningsbesluiten is geïnentariseerd aan de hand van circulaires, brieven, beleidsadviezen, in de Staatscourant gepubliceerde besluiten, enzovoort. De doorlooptijd van de afhandeling van vergunningaanvragen is bepaald door de Limburgse ziekenhuizen te benaderen met de vraag hoeveel tijd was verstreken tussen de indiening en de afhandeling van een vergunningaanvraag. De wettekst van de Wet Ziekenhuisvoorzieningen schrijft voor dat de staatssecrataris een planningsbesluit voor een artikel 18-voorziening opstelt na advies te hebben ingewonnen van de Gezondheidsraad of de Nationale Raad voor de Volksgezondheid, de Colleges van Gedeputeerde Staten en het College voor Ziekenhuisvoorzieningen. Nadat een planningsbesluit is gepubliceerd kunnen instellingen vergunningaanvragen indienen. Deze worden beoordeeld door het College voor Ziekenhuisvoorzieningen en het betreffende College van Gedeputeerde Staten, waarna een vergunning al dan niet wordt verleend. In de praktijk verliep de procedure aanzienlijk minder soepel dan de wettekst doet vermoeden. $\mathrm{Er}$ ontstond in de loop der jaren een stuwmeer van aanvragen, omdat de planningsbesluiten zolang op zich lieten wachten. De meting van de doorlooptijd van de opstelling van de planningsbesluiten heeft het volgende opgeleverd. In het snelste geval bedroeg de doorlooptijd ruim twee jaar, maar in het langzaamste geval duurde het ruim dertien jaar voordat een planningsbesluit werd afgekondigd. Dit heeft ertoe geleid dat in bepaalde gevallen een "generaal pardon" is verleend voor verlenging van reeds verstrekte vergunningen om de wachttijden niet nog langer te laten worden. Desalniettemin varieerde de doorlooptijd van de afhandeling van vergunningaanvragen toch nog van één tot vijf jaar.

De derde invalshoek om de bestuurskosten te meten vormt de inventarisatie van de tijd die is besteed aan de totstandkoming van een plan op grond van artikel 4 van de Wet Ziekenhuisvoorzieningen. Artikel 4 schreef voor dat provincies in alle regio's ten aanzien van alle categorieën van voorzieningen, zoals ziekenhuizen en verpleeghuizen, plannen moesten opstellen, waarin moest worden aangegeven 
waar hoeveel bedden of plaatsen beschikbaar waren en in de toekomst moesten zijn. Terwijl de meting plaatsvond is deze regeling aangepast. De meting is verricht aan de hand van de totstandkoming van het verpleeghuisplan in de provincie Limburg. Hiertoe is de tijd geïnventariseerd die alle direct betrokkenen minimaal aan de opstelling van het plan hebben besteed. In de wettekst van de Wet Ziekenhuisvoorzieningen is beschreven hoe een provinciaal plan tot stand diende te komen. Deze procedure was als volgt. De staatssecretaris verstrekte een aanwijzing en richtlijnen aan een provincie om een plan aangaande een bepaalde regio te ontwerpen. De provincie dient vervolgens het plan op te stellen, waarna betrokkenen in de regio hun eventuele bezwaren kenbaar kunnen maken in een inspraakronde. $\mathrm{Na}$ afloop hiervan stuurde de staatssecretaris het ontwerp ter advisering naar het College voor Ziekenhuisvoorzieningen. Hierna stelde de staatssecretaris het ontwerp vast en werd een ontwerp een definitief plan.

Eind 1983 ontving de provincie Limburg een aanwijzing om een verpleeghuisplan te ontwerpen. Inmiddels was in de provincie Limburg de experimentele invoering van de Wet Voorzieningen Gezondheidszorg van start gegaan. Hierdoor is men er bij de opstelling van het verpleeghuisplan van uitgegaan dat de Wet Ziekenhuisvoorzieningen zou opgaan in de Wet Voorzieningen gezondheidszorg, hetgeen in het begin van de jaren tachtig in de lijn der verwachtingen lag. Met de Wet Voorzieningen Gezondheidszorg beoogde het parlement onder andere het veld meer bij de besturing van de gezondheidszorg te betrekken. Bovendien zou het bereik van de wet zich uit gaan strekken over de tweede- èn de eerstelijn. Hierop anticiperend besloot de provincie tot een uitgebreide inspraak van betrokkenen en tot verruiming van de planning over de gehele langerdurende zorg. Aan de Provinciale Raad voor de Volksgezondheid is de opstelling van het ontwerpplan uitbesteed. Deze opstelling moest gebeuren aan de hand van een beleidsnotitie van de provincie. De Provinciale Raad stelde een plangroep in, waarin instellingen, de eerstelijn, gemeenten, verzekeraars, de inspectie en de provinciale griffie vertegenwoordigd waren. Dit resulteerde eind 1987 in een ontwerp-plan. Inmiddels waren echter de voorstellen tot deregulering van de Commissie-Dekker bekend geworden. Deze hielden onder meer globalisering van de planning in. Dit betekende dat de provincie het ontwerpplan weer moest aanpassen en uiteindelijk begin 1989 met de bezwarenronde kon beginnen.

De inventarisatie van de bestede tijd heeft geleerd dat in de loop van zes jaren met de opstelling minimaal 731 directe full time dagen, dat wil zeggen ruim drie mensjaren, gemoeid zijn geweest.

De eindconclusie luidt dat elk van de drie methoden geschikt is om de bestuurskosten te meten. Afhankelijk van de eisen die men stelt bijvoorbeeld aan de tijd clie de gegevensverzameling in beslag mag nemen of aan het aggragatieniveau waarover men uitspraken wenst te doen, zal men één van de methoden kunnen kjezen. 


\section{SUMMARY}

The administration of health care by the government has increased. As a result the administrative costs have risen as well. Health care administrative costs are not the costs of taking care of patients, but the costs of the administrative system. This supposition however, has never been tested with figures. This study attempts to measure the health care administrative costs.

In order to increase the knowledge on administrative costs a link was sought to economic theories. The Neoinstitutional Economics appears to connect best. The transaction costs approach is part of the Neoinstitutional Economics. According to the transaction costs approach laws can be seen as transactions. The compliance of laws generates administrative costs.

There are a lot of different names and definitions of administrative costs. In every publication a different name and definition is found, such as costs of bureaucracy. costs of planning. Based on a number of common characteristics, the following definition has been chosen: administrative costs are the costs of the administrative system to public and private organizations caused by government health care policy. Particularly in the United States-literature, a broader definition is used. Here, the health care administrative costs do not just encompass administrative costs related to government health care policy, but also all other administrative costs not directly related to government health care policy.

Measuring administrative costs would not have been a problem if administrative costs would be shown on a budget. However, national, provincial and local authority budgets contain receipt and expenditure figures. They do not provide information concerning costs and benefits. Neither do they show the costs of private institutions, like hospitals or inurance companies, caused by government health care policy. That is why administrative costs are also called "hidden costs".

This implies that if you would like to know how high the administrative costs are, you have to measure them, which has been tried in this study. There are a number of reasons why health care administrative costs are difficult to measure. There is the definition problem, as mentioned above. It is more dificult to measure the health care administrative costs as one moves to a more disaggregated level, for instance of a specific law or project. The exisiting data are not reliable.

Also, there is no fixed method to measure administrative costs. Several possible methods have been tried here.

First, the starting point was the chapter "costs of policy, administration and management" of the Financial Health Care Survey. The Financial Survey is added as an appendix to the budget of the Department of Health. It presents figures on the projected and real costs of health care facilities and at the same time it is the national health care budget. The chapter "costs of policy, administration and management" comprises the costs of governments, insurance companies and advisory bodies. This means that, compared to the definition of health care administrative costs, the administrative costs of private organizations and individuals are lacking. To complete the picture additional figures have been collected, using statistics from the Central Bureau of Statistics and the National Hospital Institute. The result was that according to the Financial Health Care Survey nearly five percent of total health care costs represent "costs of policy, administration and management". The health care administrative costs on the other 
hand represent nearly twelve percent of the total costs. If you look at the number of people working in the sector, one in every three people working in the health care is a member of the administrative staff.

Second, the time spent between the start and finish of a legal procedure was measured. The health care administrative costs were expressed in money, but in time. This method was used on measuring article 18 of the Hospital Facilities Act.

Article 18 deals with costly equipment and treatments that require very special knowledge, like cardiac surgery. So called planning resolutions state which hospitals may provide which facilities. The time of the transaction of licence applications is measured by asking the Limburg hospitals how long it took to receive a reaction on a licence application. Because the design of the planning resolutions took so much time, a queue of licence applications developped. This meant that the time between start and finish of the design of planning resolutions was two years at the minimum, but sometimes it took more than thirteen years. The time between the application and the transaction of licences appeared to varry from one to five years.

Third, the total time spent on the implementation of a regional hospital facility plan, based on article 4 of the Hospital Facilities Act was measured. Article 4 of the Hospital Facilities Act requires provinces to draw up regional plans for all categories of health care facilities, such as hospitals and nursing homes. The time measured, it took civil servants to draw up a plan on nursing homes in Limburg. In the end, after six years of planning, the result of the measurement was that it had taken at least 731 full time days to draw up the plan.

The overall conclusion of this study is that, although the health care administrative costs have seldom been measured, it is proven to be possible. Several methods have been tried. They all have restrictions, but at least they give some idea on the size of the health care administrative costs. 


\section{LIJST VAN AFBEELDINGEN}

\section{Lijst van figuren}

Figuur 1.1 Uitgebrachte nota's, wetten en financieringsregelingen in het kader van de kosten van de gezondheidszorg

Figuur 2.1 Het aantal wetten in de gezondheidszorg door de jaren heen

Figuur 5.1 De verdeling van de kosten van "beleid, administratie en beheer" naar financieringsbron

5.2 Ontwikkeling van het aantal arbeidsplaatsen in de gezondheidszorg: 1978-1984 $(1978=100)$

Figuur 7.1 De verdeling over de actoren van de bestede tijd aan de opstelling van het verpleeghuisplan in de provincie Limburg

\section{Lijst van schema's}

Schema 1.1 Probleemstelling en onderzoeksvragen

Schema 2.1 Kenmerken van bestuurskosten

2.2 De enge en brede benadering van bestuurskosten

Schema 3.1 De relatie tussen de fase in het produktieproces, de begroting en de kostenposien

3.2 Begrotingsstelsels

Schema 4.1 Methodologische criteria relevant voor de meting van bestuurskosten

4.2 Mogelijke meeteenheden van bestuurskosten

4.3 Mogeliike dataverzamelingsmethoden en de voor- en nadelen

4.4 Meetmodel van de meting van de bestuurskosten in de gezondheidszorg

Schema 5.1 De totstandkoming van het Financieel Overzicht

5.2 De hoofdstukindeling van het Financieel Overzicht door de jaren heen

Schema 6.1 De raakvlakken van artikel 18 Wet Ziekenhuisvoorzieningen met andere regelingen

6.2 Vergunningenverstrekking volgens de Wettekst van de Wet Ziekenhuisvoorzieningen

6.3 Instanties die betrokken zijn bij de uitvoering van artikel 18 door de Limburgse ziekenhuizen

6.4 Bepaling van de doorlooptijd van artikel 18

Schema 7.1 De positie van de Wet Ziekenhuisvoorzieningen door de jaren

7.2 De raakvlakken van artikel 4 Wet Ziekenhuisvoorzieningen met andere regelingen

7.3 Planprocedure volgens de wettekst van de Wet Ziekenhuisvoorzieningen

7.4 Planprocedure volgens de Wet Ziekenhuisvoorzieningen en de Wet Voorzieningen Gezondheidszorg in de provincie Limburg

7.5 Do aangepaste planprocedure na "Dekker"

7.6 Instanties die zijn betrokken bij de vitvoering van artikel 4 in de provincie Limburg

7.7 Direct en indirect betrokkenen bij de meting van de totstandkoming van het verpleeghuisplan 


\section{Lijst van tabellen}

Tabel 5.1 Het tijdpad van het Financieel Overzicht

5.2 De procentuele stijging van de kosten van beleid, administratie en beheer in verhouding tot de andere sectoren (in constante prijzen; prijspeil 1985, ten opzichte van 1985)

5.3 Het aantal bezette arbeidsplaatsen in de sector "beleid, administratie en beheer" (absoluut en met 1979 als index)

5.4 De verdeling van de kosten van beleid, administratie en beheer naar kostenmaker (in miljoenen guldens)

5.5 De beheerskosten per ziekenfonds- en per particulier verzekerde (in guldens)

5.6 Bestuurskosten in instellingen van intramurale gezondheidszorg (in miljoenen guldens)

5.7 De indirecte personeelskosten in het Kruiswerk (in miljoenen guldens)

5.8 Aanvultingen op de kosten van "beleid, administratie en beheer" (in miljoenen guldens)

5.9 Het percentage kosten van beleid, administratie en beheer van de totale kosten in de gezondheidszorg

5.10 Aanvullingen op het arbeidsplaatsenoverzicht voor "beleid, administratie en beheer" van het Financieel Overzicht (in aantallen formatieplaatsen)

Tabel 6.1 Toegestane groei van de uitgaven voor artikel 18-voorzieningen (in miljoenen guldens)

6.2 Overzicht van alle huidige artikel 18-voorzieningen en een indicatie van het aantal ziekenhuizen met minimaal één artikel 18-voorziening (31-12-1990)

6.3 Kosten van artikel 18-functies (1987-1989)

6.4 Af te handelen vergunningaanvragen bij het College voor Ziekenhuisvoorzieningen en de directie Ziekenhuiszorg en Topzorg van het ministerie van Welzijn, Volksgezondheid en Cultuur

6.5 De doorlooptijd van het planningsbesluit

6.6 De doorlooptijd van vergunningaanvragen

Tabel 7.1 Aantallen aanwijzingen, ontwerpplannen, adviesaanvragen, adviezen van vastgestelde plannen per sector van voorzieningen (per 1 jan. 1989)

7.2 De gemiddeld bestede tijd per actor per activiteit (deel 1: vòòr "Dekker")

7.3 De gemiddeld bestede tijd per actor per activiteit (deel 2: na "Dekker")

7.4 De totaal bestede tijd aan de totstandkoming van het verpleeghuisplan (in full time dagen) 


\section{GERAADPLEEGDE LITERATUUR}

Algemene Rekenkamer, Financiële informatie bij wetgeving, in: Verslag 1987,

Tweede Kamer, 1987-1988, 20 485, nrs.1-2.

Algemene Rekenkamer, Instrumenten en doelbereiking kostenbeheersing gezondheidszorg: een inventarisatie, Tweede Kamer 1986-1987, 19 794, nrs.1-2.

Algemene Rekenkamer, Planning en bouw van ziekenhuisvoorzieningen,

Tweede Kamer, 1989-1990, 21674 , nrs.1-2.

Algemene Rekenkamer, Regulering van topklinische zorg, Tweede Kamer 19901991, 22056.

Arrow, K.J., Uncertainty and the welfare economics of medical care, American Economic Review 53, 1963, p.941-973.

Baakman, Nico A.A., Kritiek van het openbaar bestuur, besluitvorming over de bouw van ziekenhuizen in Nederiand tussen 1960 en 1985, Thesis Publishers, Amsterdam, 1990.

Bakker, G.J., Bureaucratiekosten, ESB, 22-6-1983, p.556-559.

Balch, George I., The stick, the carrot, and other strategies: a theoretical analysis of governmental intervention, in: Policy implementation, penalties or incentives, John Brigham and Don W. Brown (ed.), Sage publications, Beverly Hills / London, 1980.

Beer, J.F.G.M. de, Verborgen beleidskosten in de financiële verhouding tussen rijk en lagere overheden, Bank \& Gemeente, dec. 1982, p.315-318.

Het beleid terzake van de gezondheidszorg met het oog op de kostenontwikkeling, Tweede Kamer, 1978-1979, 15 540, nrs.1-2.

Beleidsvoornemens betreffende de kostenbeheersing in de gezondheidszorg, Tweede Kamer, 1975-1976, 14 044, nr.1.

Beleidsvoornemens betreffende de kostenbeheersing in de gezondheidszorg (begeleidende brief bij eerste Financieel Overzicht), Tweede Kamer, 1977, 14044 , nr.6.

Bestek ' 81 . Hoofdlijnen van het financiële en sociaal-economische beleid voor de middeliange termijn (kabinet Van Agt I), Tweede Kamer, 1977-1978, 15 081, nrs. 1-2.

Blommaert, A.M.M. en J.M.J. Blommaert, Bedrijfseconomische analyses, Stenfert Kroese BV, Leiden, 1988.

Bogaard, F. Uit den, Zeltbeheer bij de rijksdienst, ESB, 21-3-1984, p.279-284.

Bokkes, W.Th.M., Privatisering belicht vanuit de transactiekostenbenadering, Proefschrift, Enschede, 1989.

Boorsma, P.B. Meerjarenramingen en prestatiebegrotingen van het rijk Openbare uitgaven, 13, 1981, 1, febr., p.3-25.

Boot, J.M. en M.H.J.M. Knapen, De Nederlandse gezondheidszorg, Het Spectrum, Utrecht, 1986.

Bressers, J.Th.A., Analyse en evaluatie van beleidseffecten, in: Handboek beleidsevaluatie, H.J. Blommestein, J.Th.A. Bressers en A. Hoogerwert (red.), Samson, Alphen aan den Rijn, 1984.

Breton, A. and R. Wintrobe, The logic of bureaucratic conduct, Cambridge University Press, Cambridge, 1985.

Centraal Bureau voor de Statistiek, Intramurale gezondheidszorg in Nederland, Voorburg, 1981, 1982, 1983, 1984.

Centraal Bureau voor de Statistiek, Kosten en financiering van de gezondheidszorg 1972-1988, Voorburg, 1991.

Centraal Orgaan Tarieven Gezondheidszorg, Vademecum, Utrecht, november 1989. 
Centrale Raad voor de Volksgezondheid, Benadering van de ontwikkeling van de kosten van de Nederlandse Gezondheidszorg. Rijswijk, 1974, 1975, 1976.

Centrale Raad voor de Volksgezondheid, Notitie derde Financieel Overzicht Gezondheidszorg, Rijswijk, febr. 1980.

Centrale Raad voor de Volksgezondheid, Advies inzake het Financieel Overzicht Gezondheidszorg, Rijswijk, nov. 1980.

Centrale Raad voor de Volksgezondheid, Advies inzake de opstelling van het $5 e$ Financieel Overzicht Gezondheidszorg, Rijswijk, april 1981.

Centrale Raad voor de Volksgezondheid, Advies inzake de opstelling van het $6 \mathrm{e}$ Financieel Overzicht Gezondheidszorg, Rijswijk, mei 1982.

Clarke, Roger and Tony McGuiness (ed.), The economics of the firm, Basil Blackwell, Oxford, 1987.

College voor Ziekenhuisvoorzieningen, Advies inzake de concept-richtlijnen ex artikel 3 van de Wet Ziekenhuisvoorzieningen voor het ontwerpen van plannen, tevens beoordelingskader bij de toepassing van artikel 29, eerste lid, van de Wet Ziekenhuisvoorzieningen, Utrecht, maart 1981.

College voor Ziekenhuisvoorzieningen, Advies inzake evaluatie planproces W.Z.V. Utrecht, 1987.

College voor Ziekenhuisvoorzieningen, Advies inzake het gebruik van artikel 18 WZV, Utrecht, febr. 1987.

College voor Ziekenhuisvoorzieningen, Brief aan de staatssecretaris van Welzijn, Volksgezondheid en Cultuur over continueringsaanvragen ex art. 18 WZV, Utrecht, 16 febr. 1987.

College voor Ziekenhuisvoorzieningen, Jaarverslag 1975, 1979, 1984, 1986, 1987, 1988, Utrecht, 1976, 1980, 1985, 1987, 1988, 1989.

Commissie-Dekker, Commissie Structuur en Financiering Gezondheidszorg, Rapport "Bereidheid tot verandering", Staatsuitgeverij, 's-Gravenhage, 26 mrt. 1987.

Brief "Regeringsstandpunt inzake rapport "Bereidheid tot verandering" (eerste Dekker-brief), 5 juni 1987, Tweede Kamer, 1986-1987, 19 945, nrs. 4-5.

Brief van de minister en ván de staatssecretaris van WVC aan de voorzitter van de Tweede Kamer der Staten-Generaal (tweede Dekker-brief), 3 nov. 1987, Tweede Kamer, 1987-1988, 19 945, nr. 19.

Nota "Verandering verzekerd, stapsgewijs op weg naar een nieuw stelsel van zorg" (derde Dekker-brief), 7 mrt. 1988, Tweede Kamer, 1987-1988, 19 945, nrs.2728.

Commissie-Geelhoed, Deregulering van overheidsregelingen, Tussenbericht van de Commissie vermindering en vereenvoudiging van overheidsmaatregelen, Tweede Kamer, 1982-1983, 17 931, nr.3.

Commissie-Geelhoed, Eindbericht van de commissie vermindering en vereenvoudiging van overheidsregelingen, Tweede Kamer, 1983-1984, 17 931, nr.9.

Commissie-Vonhoff, Eindrapport van de Adviescommissie sanering planprocedures, Carnavalstocht der planprocedures, 's-Gravenhage, 1985.

Comptabiliteitswet 1976, editie Schuurman \& Jordens, Zwolle, 1977.

Cook, T.D. and D.T. Campbell, Quasi-experimentation: design and analysis issues for field settings, Rand McNally, Chicago, 1979.

Coq, J.G. le., Verantwoording van budgettaire gevolgen van beleidsvoornemens en nota's, Beleidsanalyse, '82-3, p.29-30.

Crince Le Roy, R., De vierde macht: een hernieuwde kennismaking, Vuga, 's-Gravenhage, 1976.

Cyert, Richard M. and James G. March, A behavioral theory of the firm, Prentice-Hall, Englewood Cliffs, 1963.

Danzon, Patricia M., Hidden overhead costs: is Cananda's system really less expensive? Health Affairs, Spring 1992, p.21-43. 
Doel, J. van den, Demokratie en welvaartstheorie, Samsom, Alphen aan den Rijn, 1978.

Doelen, F.C.J. van der, Informatie, prikkels en voorschriften: beperkende en verruimende sturingsmodellen, Beleidswetenschap 1988/3, p.197-211.

Doelen, F.C.J. van der en P-J. Klok, Beleidsinstrumenten, in: Overheidsbeleid A. Hoogenwerf (red.), Samson H.D. Tjeenk Willink, Alphen aan den Rijn, 1989.

Doorn, J.A.A. van en C.J.M. Schuyt (red.), De stagnerende verzorgingsstaat, Boom, Meppel, 1982

Drenth, Pieter J., Onderzoek in de arbeids- en organisatiepsychologie: principes en methoden, in: Handboek arbeids- en organisatiepsychologie.

P.J.D. Drenth, H. Thierry, P.J. Willems en Ch.J. de Wolff (red.), Van Loghum Slaterus, Deventer, 1989.

Duijn, J.J. van, Macro-economische gevolgen van deregulering, Beleid \& Maatschappij, 1982/8, p.213-219

Duuren, R. van, D.H. Posthuma, F.A.M. Ruygt, Marktwerking, normuitkeringen en risicoselectie, ESB, 13-12-1989, p.1232-1235.

Easton, D., A framework for political analysis, University of Chicago Press, Chicago, 1979.

Eggertsson, Thráinn, Economic behavior and institutions, Cambridge University Press, Cambridge, 1990.

Financieel Overzicht van de Gezondheidszorg waarin opgenomen een raming van de kosten tot 1982, $\mathrm{nr} .1$, Ministerie van Volksgezondheid en Milieuhygiëne, september 1977.

Financieel Overzicht van de Gezondheidszorg waarin opgenomen een raming van de kosten tot 1983, nr.2, Tweede Kamer, 1978-1979, 15300 , hst.XVII, nr.7.

Financieel Overzicht van de Gezondheidszorg waarin opgenomen een raming van de kosten tot 1984, nr.3. Tweede Kamer, 1979-1980, 15 800, hst.XVII, nr.7.

Financieel Overzicht van de Gezondheidszorg waarin opgenomen een raming van de kosten tot 1985, nr.4. Tweede Kamer, 1980-1981, 16 400, hst.XVII, nr.9.

Financieel Overzicht van de Gezondheidszorg waarin opgenomen een raming van de kosten tot 1986, nr.5, Tweede Kamer, 1981-1982, 17 100, hst.XVII, nr.14.

Financieel Overzicht van de Gezondheidszorg 1984, Tweede Kamer, 1983-1984, 18100 , hst.XVI, nr.9.

Financieel Overzicht Gezondheidszorg en Maatschappelijke Dienstverlening 1985 waarin opgenomen een raming van de kosten tot 1990. Tweede Kamer, 19841985, 18 600, hst.XVI, nr.9.

Financieel Overzicht Gezondheidszorg en Maatschappelijk Welzijn 1986 waarin opgenomen een raming van de kosten tot 1991. Tweede Kamer, 1985-1986, 19246 , nrs. $1 \cdot 2$.

Financieel Overzicht Gezondheidszorg en Maatschappelijk Welzijn 1987 waarin opgenomen een raming van de kosten tot 1991, Tweede Kamer, 1986-1987, 19703 , nrs. 1-2.

Financieel Overzicht Gezondheidszorg en Maatschappelijk Welzijn 1988 waarin opgenomen een raming van de kosten tot en met 1990, Tweede Kamer, 1987-1988, 20 209, nrs. 1-2.

Financieel Overzicht Zorg 1989, Tweede Kamer, 1988-1989, 20 848, nrs.1-2. Financieel Overzicht Zorg 1990, Tweede Kamer, 1989-1990, 21.310, nrs.1-2. Financieel Overzicht Zorg 1991, Tweede Kamer, 1990-1991, 21 812, nrs.1-2.

Financiële verhouding Rijk/lagere overheden. Heroverweging collectieve uitgaven (rijksbegroting). Deelrapport 33, Tweede Kamer, 1981-1982, 16 625, nr.41.

Flora, Peter and Arnold J. Heidenheimer, The development of welfare states in Europe and America, Transaction, New Brunswick, 1984.

Gastkemper, H.J. en E.H. Klijn, Ook deregulering leidt tot remise, Bestuurswetenschappen, 1986, nr.1, p.23-38. 
Gedeputeerde Staten van Limburg, Beleidsvisie: verpleeghuizen, observatieafdelingen voor ouderen, geriatrische afdelingen in algemene ziekenhuizen, geriatrische poliklinieken in algemene ziekenhuizen voor de planperiode 19881992 en 1992-1996, Maastricht, febr. 1987.

Gedeputeerde Staten van Limburg, Opdracht tot het in concept opstellen van voorontwerpplannen voor de langerdurende gezondheidszorg in de gezondheidsregio's Noord-Limburg en Zuid-Limburg, Maastricht, 16 sept. 1986.

Geelhoed, L.A., Deregulering en de grote operaties, in: De grote operaties,

F.K.M. van Nispen en D.P. Noordhoek (red.), Kluwer, Deventer, 1986

Geelhoed, L.A., De interveniërende staat, aanzet voor een instrumentenleer, Staatsuitgeverij, 's-Gravenhage, 1983.

Gemeentelijke comptabiliteitsvoorschriften, Staatsblad 1982, 594.

Geritse, R. en J.D. Poelert, Middelen op maat, naar een verdeelsleutel voor uitkeringen aan zorgverzekeraars, Instituut voor Onderzoek naar Overheidsuitgaven, 's-Gravenhage, 1990.

Gezondheidsraad, Beleidsvoering artikel 18 WZV, 's-Gravenhage, 8 april 1988.

Gezondheidsraad, Jaaradvies Gezondheidszorg 1989, 's-Gravenhage, 24 mei 1989.

Gezondheidsraad, Wijziging van artikel 18 van de Wet Ziekenhuisvoorzieningen, 's-Gravenhage, 3 november 1989.

Giessen, M. van, Effectiviteitsonderzoek, Beleidsanalyse, 1980-2, p.5-13.

Glasbergen, P., Visies op beleid, Kobra, Amsterdam, 1984.

Goedhart, C., Hoofdlijnen van de leer der openbare financiën, Stenfert Kroese, Leiden, 1975.

Goemans, T. en W.F. Mijnhardt, Voorkomen is beter dan dereguleren, Bestuur, nr. 1, jan. 1989, p.17-21.

Goor, $H$. van, Politieke participatie van collectiviteiten: pressiegroepen, in: Politiek in Nederland, R.B. Andeweg, A. Hoogerwerf en J.J.A. Thomassen (red.), Samson Uitgeverij, Alphen aan den Rijn, 1989.

Grondwet, editie Schuurman \& Jordens nr.1-I, Tjeenk Willink, Zwolle, 1987.

Groot, A.D. de, Methodologie, Mouton, 's-Gravenhage, 1981.

Groot, J. de, Overheidsregulering in de gezondheidszorg: de case van het vestigingsbeleid voor huisartsen, Beleidswetenschap, 2 (2), 1988, p.121-144.

Hallwood, C. Paul, Transaction costs and trade between multinational corporations, Unwin Hyman, Boston, 1990.

Hartley, C.,M. Brecht, P. Pagerey, c.S., Subjective time estimates of work tasks by office workers, Journal of Occupational Psychology, 1977, 50, p.23-36.

Hazeu, C.A., Prestatiebegroting op proef, een tussenstand, Openbare Uitgaven 12 (1980) 6 (dec.), p.298-307.

Hermans, M., Een budgetteringseenheid voor het bacteriologisch laboratorium. Mechelen, 1985.

Heroverweging Binnenlands Bestuur, Heroverweging collectieve uitgaven. Deelrapport 2., Tweede Kamer, 1980-1981, 16 625, nr.7.

Heroverweging derde ronde Heroverweging Collectieve uitgaven, Samenvattend eindrapport derde ronde. Tweede Kamer, 1983-1984, 16 625, nr.66.

Heroverweging planprocedures lagere publiekrechtelijke lichamen, Eindrapport van de werkgroep, 's-Gravenhage, dec. 1983.

Herovenwegingswerkgroep "Wettelijke voorschriften in verband met de economische ontwikkeling", Heroverweging collectieve uitgaven (rijksbegroting) Deelrapport 31. Regulering en deregulering, Tweede Kamer, 1981-1982, 16 625, nr.56.

Heij, P.R., Een proeve van decentralisatie: rijksbijdrageregeling, Instituut voor Onderzoek naar Overheidsuitgaven, 's-Gravenhage, 1984.

Hilferink, J.D., Productiviteitsonderzoek, ESB, 4-8-1976, p.742-743. 
Himmelstein, David U. and Steffie Woolhandler, Sounding board, cost without benefit, administrative waste in U.S. Health Care, The New England Journal of Medicine, Feb. 13 1986, vol. 314, no.7, p.441-445.

Hofland, J. en J.C.M. van Niekerk, Bedrijvige overheid: naar een betere informatievoorziening over de bedrijfsvoering van de overheid, Instituut voor Onderzoek naar Overheldsuitgaven, 's-Gravenhage, 1985.

Hofland J. en P.J.M. Wilms, Onder behandeling: strategische keuzen bij de kostenbeheersing in de gezondheidszorg, Instituut voor Onderzoek naar Overheidsuitgaven, 's-Gravenhage, 1984.

Honigh, M., Doeltreffend beleid, proefschrift, Assen, 1986.

Hoofdgroep Welzijn / Gedeputeerde Staten van Limburg, Ontwerpplan verpleeghuizen voor de gezondheidsregio's 26 en 27, Maastricht, 14 febr. 1989.

Hoogerwerf, A., De groei van de overheid in Nederland sinds 1900: aspecten van omvang, ontwikkeling, onevenwichtigheid en overbelasting, Bestuurswetenschappen, juli/aug. 1977, nr.4, p.243-265.

Hoogenwerf, A. (red.), Overheidsbeleid, Samson H.D. Tjeenk Willink, Alphen aan den Rijn, 1989.

Janssen, Richard, Paul Kocken en Jan van der Made (red.), Externe adviesorganen in de gezondheidszorg, De Tijdstroom, Lochem / Gent, 1987.

Janssen, Richard and Jan van der Made. Privatisation in health care: concepts, motives and policies. Health Policy, 14 (1990), p.191-202.

Juffermans. Paul, Staat en gezondheidszorg in Nederland, Socialistiese Uitgeverij Nijmegen, Nijmegen, 1982.

Kam, C.A. de, Op weg naar een open einde, ESB, 11-7-1990, 75, nr. 3765, p.640-644 .

Kar, H.M. van de, Beheersen en begroten, in: Naar een beheersbare collectieve sector, D.J. Wolfson (red.), Kluwer, Deventer, 1981.

Kar, H.M. van de, Economische indicatoren ten behoeve van het welzijnsbeleid, Erasmusuniversiteit, Rotterdam, 1980.

Kar, H.M. van de, Heroverwegen en opnieuw beginnen, ESB, 21-10-1981, p.1040$-1043$.

Kasdorp, J.P. en G. Schrijvers, Deregulering, een recept voor de gezondheidszorg?, Tijdschrift voor Sociale Gezondheidszorg, 62, 1984, nr.10, p.390-402.

Kertzman, E.N., Deregulering versus regulering, een overzicht, Bestuurswetenschappen, april/mei 1983, 4, p.234-246.

KLOZ Informatiesysteem Gezondheidszorg, Jaarboek 1987, 1988, Houten, 1988, 1989.

Klaver, J.A.M. en J.G. Siccama, Integratie van politicologie en economie, Acta Politica, 1974, vol. 9, p.125-161.

Knapen, Mat, Verbouwingen in de gezondheidszorg 1921-1991, van kennis / technologie, gezag en expansie via planning, kostenbeheersing en wetgeving naar een nieuwe zorgmarkt, Tijdschrift voor Sociale Gezondheidszorg, 70, 1992, nr.11, p.5-15.

Kneppes-Heynert. E.M., Een economische en juridische analyse van franchising tegen de achtergrond van een property rights- en transactiekostenbenadering, Proefschrift, Groningen, 1988.

Koopmans, L. en A.H.E.M. Wellink, Overheidsfinanciën, Stenfert Kroese, Leiden, 1987.

Koster, H.C.C.E., H.D.C. Roscam Abbing en L.F. Markenstein, Wet- en regelgeving gezondheidszorg: bestuursinstrumenten. Deel I: Bestuursinstrumenten nader belicht, Rijksuniversiteit Limburg, Maastricht, 1987.

Kraan, D.J., Bureaucratietheorie en organisatie van de rijksdienst, Openbare Uitgaven, 1992, nr.4, p.160-169. 
Kraan, D.J., Deregulering: een begripsbepaling, Beleid \& Maatschappij. 1982/8, p.177-181.

Krol, H.J.E. en J. Passchier, Evaluatie planproces Wet Ziekenhuisvoorzieningen, Nationaal Ziekenhuisinstituut, Utrecht, 1986

Lapré, R.M. en F.F.H. Rutten, Economische aspecten van overheidsingrijpen in de gezondheidszorg, in: Economie van de gezondheidszorg. R.M. Lapré en F.F.H. Rutten (red.), De Tijdstroom, Lochem, 1988.

Leenen, H.J.J. en H.D.C. Roscam Abbing, Bestuurlijk gezondheidsrecht, Samson H.D. / Tjeenk Willink, Alphen aan den Rijn / Brussel, 1986.

Leeuw, A.C.J. de, De wet van de bestuurlijke drukte, Van Gorcum, Assen / Maastricht, 1984.

Leibenstein, Harvey, Allocative efficiency vs. "x-efficiency", American Economic Review, vol.56, no.3, june 1966, p.392-415.

Maarse, J.A.M., Overheid en volksgezondheid, in: Beleid en beheer in de gezondheidszorg, J.A.M. Maarse en I.M. Mur-Veeman (red.), Van Gorcum, Assen / Maastricht, 1990.

Maarse, J.A.M., Politieke besluitvorming in de gezondheidszorg, in: Beleid en beheer in de gezondheidszorg, J.A.M. Maarse en I.M. Mur-Veeman (red.), Van Gorcum, Assen / Maastricht, 1990.

Maarse, J.A.M., Uitvoering van beleid: enkele thema's, in: Uitvoering van overheidsbeleid. Gemeenten en ambtelijk gedrag belicht, A.F.A. Korsten en W. Derksen (red.), Stenfert Kroese, Leiden, 1986.

Maarse, J.A.M., Uitvoering en effecten van arbeidsmarktbeleid, Proefschrift, Enschede, 1983.

Maarse, J.A.M. en J. Moen, Instrumenten van beleid: de doorwerking vanuit een organisatie-theoretisch perspectief, Beleidswetenschap, 1991, 2, p.132-147.

Made, J.H. van der en J.G.A. van Mierlo, Het particulier initiatief in de gezondheidszorg, in: Beleid en beheer in de gezondheidszorg. J.A.M. Maarse en I.M. Mur-Veeman (red.), Van Gorcum, Assen / Maastricht. 1990.

Made, J.H. van der en L.M.C. Savelkoul, Particulier initiatief in de gezondheids zorg, in: Het particulier initiatief in de Nederlandse verzorginsmaatschappij, J.G.A. van Mierlo en L.G. Gerrichhauzen (eindredactie), De Tijdstroom, Lochem / Gent, 1988.

Mandema, E., G. den Otter, H.A. van Peperzeel, A.Th. Schweizer, Topklinische zorg in de jaren '91-'94, het maken van keuzen, Advies aan de Staatssecretaris van Welzijn, Volksgezondheid en Cultuur, 7 juli 1990.

March, James G. and Herbert A. Simon, Organizations, John Wiley \& Sons, New York, 1958.

Meulmeester, M., Het Financieel Overzicht Gezondheidszorg als toetsingsinstrument voor het gevoerde beleid, Zoetermeer, mei 1986.

Mijn, W.B. van der, Deregulering, gezien vanuit de hulpverleners, Tijdschrift voor Sociale Gezondheidszorg, 62, 1984, nr.10, p.408-411.

Miljoenennota 1982, hist.5. De collectieve sector (p.56-63).

Ministerie van Financiën, Handleiding Prestatiebegroting, 's-Gravenhage, 1982.

Ministerie van Welzijn, Volksgezondheid en Cultuur, Zorg in getal 1992, Rijswijk, 1992

Mitnick, Barry M., The political economy of regulation, Columbia University Press, New York, 1980.

Moesen, W. en J. Vanneste, België: Gemeentelijke uitgaven en bureaucratische kosten, Openbare uitgaven, 14, 1982, 6 , december, p.271-284.

Moesker, K.M. en F.P. van Tulder, Openbaar bestuur en produktie, Openbare Uitgaven, 1992, nr.2, p.67-76.

Mol, N.P., Bedrijfseconomie voor de collectieve sector, Samson H.D. Tjeenk Willink / Vuga Uitgeverij, Alphen aan den Rijn / 's-Gravenhage, 1986. 
Montfort, A.P.W.P. van, Open-eindregelingen in de gezondheidszorg, Openbare Uitgaven, 2, 1990, p.68-74.

Muckler, F.A., Evaluating productivity, in: Human performance and productivity,

E.A. Fleishman (ed.), Lawrence Erlbaum Associates, New Jersey, 1982.

Mur-Veeman, I.M. en anderen, Evaluatie integrale invoering Wet Voorzieningen Gezondheidszorg in de provincie Limburg. Deel 1,2, 3, Rijksuniversiteit Limburg, Maastricht, 1984, 1985, 1986.

Musgrave, R.A. and P.B. Musgrave, Public finance in theory and practice, McGraw-Hill, New York, 1984.

Nationaal Ziekenhuisinstituut, Financiële statistiek in de instellingen van intramurale gezondheidszorg, Utrecht, 1979, 1980, 1981, 1982, 1983, 1984.

Nationaal Ziekenhuisinstituut, De intramurale gezondheidszorg in cijfers per 1 jan. 1987, Utrecht, 1988.

Nationale Kruisvereniging, Kruiswerk 1982/83, 84, 85, 86, verslag Nationale Kruisvereniging, Bunnik, 1984, 1985, 1986, 1987.

Nationale Kruisvereniging, Kruiswerk in beeld, Bunnik, 1985.

Nationale Raad voor de Volksgezondheid, Advies inzake de opstelling van het $7 \mathrm{e}$ Financieel Overzicht Gezondheidszorg, Rijswijk, april 1983.

Nationale Raad voor de Volksgezondheid, Advies inzake de opstelling van het Financieel Overzicht van de gezondheidszorg 1985, Zoetermeer, april 1984.

Nationale Raad voor de Volksgezondheid, Advies inzake de opstelling van het FOGM 1986, Zoetermeer, april 1985.

Nationale Raad voor de Volksgezondheid, Advies inzake de opstelling van het FOGM 1987, Zoetermeer, mei 1986.

Nationale Raad voor de Volksgezondheid, Advies inzake de opstelling van het FOGM 1988, Zoetermeer, febr, 1987.

Nationale Raad voor de Volksgezondheid, Advies inzake de opstelling van het FOGM 1989, Zoetermeer, mrt. 1988.

Nationale Ziekenhuisraad, Brief aan de Staatssecretaris van Welzijn, Volksgezondheid en Cultuur over het rapport "Beleidsvoering artikel 18 Wet Ziekenhuisvoorzieningen", Utrecht, 10 mei 1988.

Staatssecretaris van Welzijn. Volksgezondheid en Cultuur (dir. Financiering en Planning), Brief over artikel 18-beleid aan Nationale Ziekenhuisraad, Rijswijk, 17 aug. 1988.

Needham, Douglas, The economics and politics of regulation, Little, Brown and Company, Boston, 1983.

Nentjes, A., De ontwikkeling van de economische theorie, Wolters-Noordhoff, Groningen, 1979.

Nispen, F.K.M. en D.P. Noordhoek, De grote operaties: de overheid onder het mes of snijden in eigen vlees?, Kluwer, Deventer, 1986.

Nispen, F.K.M. van en Th. van der Tak, Herregulering, Beleid \& Maatschappij, 1984/12, p.367-372.

Niskanen, W.A., Bureaucracy and representative government, Aldine-Atherton, Chicago, 1971.

Nota Verandering Verzekerd, stapsgewijs op weg naar een nieuw steisel van zorg, "derde Dekker brief", Tweede Kamer, 1987-1988, 19 945, nr.27-28.

Onderzoeksbureau IGG, Kosteninventarisatie uitvoering besluit proefgemeenten, Interimrapport, 1985, Eindrapport, 1986, Groningen/Rotterdam.

Parkinson, C. Northcote, Oefeningen in beleid, Scheltema \& Holkema, Amsterdam, 1959 .

Patton, Michael Quinn, Practical evaluation, Sage Publications, Beverly Hills / London / New Delhi, 1982.

Perrow, Charles, Complex organizations, Random House Inc., New York, 1986.

Plangroep Langerdurende Gezondheidszorg, Diverse vergaderverslagen. 
Postma, J.K.T., Overheid en verzorgingsstaat bij economische teruggang, in:Privatisering en deregulering: van verzorgingsstaat naar waarborgstaat, M.M. Kaag (red.), Raad voor het Binnenlands Bestuur, 's-Gravenhage, 1983.

Provinciale Comptabiliteitsvoorschriften 1979, Staatsblad 1979, 324.

Provinciale Raad voor de Volksgezondheid Limburg, Evaluatie concept-voorontwerpplannen langerdurende gezondheidszorg, Maastricht, febr. 1988.

Provinciale Raad voor de Volksgezondheid Limburg, Algemeen Bestuur. Dagelijks Bestuur, Relevante vergaderverslagen, Provincie Limburg, derde afdeling.

Planprocedure en provinciale adviesstructuur op het terrein van de gezondheidszorg en de subsidiëring van algemene samenwerkingsverbanden gezondheidszorg, Maastricht, 3 juli 1984.

Regelen met betrekking tot de tarieven van organen voor gezondheidszorg (WTG), Gewijzigde motie van de leden Lansink en De Korte, ter vervanging van die gedrukt onder nr.45, Tweede Kamer, 1979-1980, 14 182, nr.48.

Gewijzigd ontwerp van wet, Tweede Kamer, 1979-1980, 14 182, nr. 9

Reinhardt, Uwe E., The medical B-factor: bureaucracy in action, The Washington Post, 1991.

Rijksbegroting 1987, Tweede Kamer, 1986-1987, 19 700, hst.XVI.

Ringeling, A.B., De instrumenten van het beleid, Samson Uitgeverij, Alphen a/d Rijn, 1983.

Robinson, James C. and Harold S. Luft, Competition, regulation, and hospital costs, 1982 to 1986, JAMA, nov. 11, 1988, vol. 260, no. 18, p.2676-2681.

Roo, A. de en J.A.M. Maarse, Understanding the central-local relationship in health care: a new approach, International Journal of health planning and management, vol. 5, 1990, p.15-25.

Roscam Abbing, E.W. (red.), Bouw en werking van de gezondheidszorg in Nederland, Bohn, Scheltema \& Holkema, Utrecht/Antwerpen, 1983.

Roscam Abbing, H.D.C., In beperking toont zich de meester, Samson, Alphen a/d Rijn, 1983.

Roscam Abbing, H.D.C., Het kraptemodel in de gezondheidszorg en rechten van verzekerden, Tijdschrift voor Openbaar Bestuur, 1 juni 1990, 16, nr.11, p.240243.

Roscam Abbing, H.D.C., Overheid en het recht op gezondheidszorg, tussentijdse balans, Tijdschrift voor Gezondheidsrecht, mei/juni 1984, nr.3, p.126-134.

Roscam Abbing, H.D.C., Wettelijke ziektekostenverzekeringen en sturingsmechanismen in de Nederlandse gezondheidszorg, Vlaams Tijdschrift voor Gezondheidsrecht, 1984, p.301-312.

Roscam Abbing, H. en F.F.H. Rutten, Verleden en heden van het ziektekostenverzekeringsstelsel in Nederland, Kluwer, Deventer, 1985.

Rosenthal, U., M.P.C.M. van Schendelen en A.B. Ringeling, Openbaar bestuur, organisatie, politieke omgeving en beleid, Samson H.D. Tjeenk Willink, Alphen a/d Rijn, 1987.

$\mathrm{Ru}, \mathrm{H}$.J. de, Wijziging van sturingsinstrumenten, in: De terugtred van regelgevers, W. Derksen, Th.G. Drupsteen en W.J. Witteveen (red.), Tjeenk Willink, Zwolle, 1989.

Rutten, F.F.H., Deregulering en privatisering vanuit economische invalshoek, Tijdschrift voor Sociale Gezondheidszorg, 62, 1984, nr.10, p.411-415.

Samuelson, Paul A. and William D. Nordhaus, Economics, McGraw-Hill, New York etc., 1989.

Schendelen, M.P.C.M. van, Politieke achtergronden van deregulering, Beleid \& Maatschappij, 1982/8, p.190-202.

Schild, J.A., De ontwikkeling van de prestatiebegroting, Beleidsanalyse, 85-1-2, p.21-26. 
Schultze, Charles L., The public use of private interest, Brookings, Washington, 1977.

Schut, F.T., Gezondheidszorg en mededingingsbeleid, ESB, 15-11-1989, p.11291133.

Segers, J.H.G., Sociologische onderzoeksmethoden, Van Gorcum, Assen / Amsterdam, 1977.

Sluyters, B., Gezondheidszorg, in: De terugtred van regelgevers, W. Derksen, Th.G. Drupsteen en W.J. Witteveen (red.), Tjeenk Willink, Zwolle, 1989.

Staatssecretaris van Volksgezondheid, Aanwijzing gezondheidsregio's Noord- en Zuid-Limburg voor de Hoofdgroep verpleeghuizen, 21 dec. 1983.

Staley, Charles, A history of economic thought: from Aristotle to Arrow, Basil Blackwell, Cambridge Mass., 1989.

Structuurnota Gezondheidszorg. Tweede Kamer, 1973-1974, 13 012, nrs.1-2.

Swanborn, P.G., Basisboek sociaal onderzoek, Boom, Meppel, 1982.

Swanborn, P.G., Methoden van sociaal-wetenschappelijk onderzoek, Boom, Meppel, 1982.

Thorpe, Kenneth E., Inside the black box of administrative costs, Health Affairs, Summer 1992, p.41-55.

Topklinische zorg 1991-1994, Tweede Kamer, 1990-1991, 21 944, nr.1.

Tullock, Gordon, Book review: Bureaucracy and representative government by William A. Niskanen, Public Choice, 12 ,spring 1972, p.119-124.

United States General Accounting Office, Canadian Health Insurance, lessons for the United States, Washington, 1991.

Ven, W.P.M.M. van de, Perestrojka in de gezondheidszorg, ESB, 11 juli 1990 , p.628-631.

Verbetering van de bedrijfsvoering bij de overheid (Zelfbeheer I). Heroverweging derde ronde. Deelrapport nr.53, 's-Gravenhage, dec. 1983.

Verslag van een mondeling overleg (5 mrt. 1981) van de Vaste Commissie voor Volksgezondheid met de Staatssecretaris inzake het Financieel Overzicht van de gezondheidszorg, Tweede Kamer, 1980-1981, 16 400, hst. XVII, nr. 65. bevat als bijlage: "Nota inzake het Financieel Overzicht van de Gezondheidszorg".

Visscher, W., Het Financieel Overzicht van de Gezondheidszorg als instrument voor financieel beleid, in: R.M. Lapré en F.F.H. Rutten (red.), Economie van de Gezondheidszorg, De Tijdstroom, Lochem, 1988.

Volksgezondheidsnota 1966, Tweede Kamer, 1965-1966, 8462.

De rol van de rekengroepen bij de voorbereiding van het FOZ, Voorraad, maandblad van de Nationale Raad voor de Volksgezondheid, 5e jrg., nr.8, sept. 1989, p.9.

Vor, M.P.H. de, The growth of government, economic history, transaction costs and property rights, Proefschrift, Tilburg, 1992.

Vos, L.M., Invloeden van artikel 18-voorzieningen op de kostenstruktuur van algemene ziekenhuizen, Nationaal Ziekenhuis Instituut, Utrecht, 1986.

Vroom, B. de, Zelfregulering, in: De terugtred van regelgevers, W. Derksen, Th.G. Drupsteen en W.J. Witteveen (red.), Tjeenk Willink, Zwolle, 1989.

Vroom, C.W., Bureaucratie, het veelzijdig instrument van de macht, proefschrift, Tilburg, 1979.

Vught, F.A. van en J.H.M. van Doorn, Beleidsexperimenten in het openbaar bestuur, Raad voor het Binnenlands Bestuur, 's-Gravenhage, 1983.

Waaldijk, C., Wetgevingswijzer, Koninklijke Vermande BV, Lelystad, 1985.

Werken aan zorgvernieuwing. Tweede Kamer, 1989-1990, 21 545, nrs. 1-2, bevat als bijlage: "Notitie inzake de stelselwijziging zorgsector".

Wet Tarieven Gezondheidszorg, editie Schuurman \& Jordens no. 70, Tjeenk Willink, Zwolle, 1986. 
Wet Ziekenhuisvoorzieningen (inclusief aanvullingen 1988 en 1989), editie Schuurman \& Jordens no. 167, Tjeenk Willink, Zwolle, 1986.

Wijziging van de Wet op het Wetenschappelijk Onderwijs en de Wet Ziekenhuisvoorzieningen met betrekking tot de academische ziekenhuizen, Tweede Kamer, 1988-1989, 20 889, nr.3.

Wet van 4 oktober 1990, houdende wijziging van de Wet op het Wetenschappelijk Onderwijs en de Wet Ziekenhuisvoorzieningen met betrekking tot de academische ziekenhuizen (aanpassing regelgeving academische ziekenhuizen), Staatsblad 1990, 535.

Wolfson, D.J., Publieke sector en economische orde, Wolters-Noordhoff, Groningen, 1988.

Woolhandler, S. and D.U. Himmelstein, The deteriorating administrative efficiency of the U.S. Health Care System, The New England Journal of Medicine, vol. 324, no. 18, May 2, 1991, p.1253-1258.

Yin, R.K., Case study research: design and methods, Sage Publications, Beverly Hills, 1984.

Zee, J. van der, Het falen van het structuurbeleid in de gezondheidszorg, in: De Nota 2000 ter discussie, F. Schrameijer, J.M. Boot, E. Jurg, e.a. (red.), Samson Stafleu, Alphen a/d Rijn 1987.

Ziekenfondsraad, Advies inzake het 6 e Financieel Overzicht, Amstelveen, juni 1982.

Ziekenfondsraad, Advies inzake het 7e Financieel Overzicht, Amstelveen, juni 1983.

Ziekenfondsraad, Financieel Overzicht Gezondheidszorg 1985, Amstelveen, juni 1984.

Ziekenfondsraad, FOGM 1986. Amstelveen, juni 1985.

Ziekenfondsraad, FOGM 1987, Amstelveen, juni 1986.

Ziekenfondsraad, FOGM 1988, Amstelveen, juni 1987.

Ziekenfondsraad, FOGM, Amstelveen, juni 1988.

Ziekenfondsraad, Nader advies tweede fase stelselwijziging, Amstelveen, 1991 


\section{DANKWOORD}

Dit proefschrift zou nooit zijn voltooid zonder de ondersteuning door mijn ouders, broers, familie, vrienden en kennissen.

Verder dank ik mijn collega's en oud-collega's, bij wie ik steeds terecht kon voor een praatje of advies.

De leden van de Landelijke Rijvereniging "Slenaken", de vereniging "Oos Mergelland Sjaop" en de AlO-vereniging Rijksuniversiteit Limburg hebben ervoor gezorgd dat ik geen tijd had om totaal op te gaan in mijn werk. 


\section{CURRICULUM VITAE}

Monique Hermans werd op 4 februari 1962 geboren te Wahlwiller-Wittem. Van 1974 tot 1981 bezocht zij het gymnasium $\alpha$ aan het Coriovallum College te Heerlen. Van 1981 tot 1985 studeerde zij Gezondheidswetenschappen met als afstudeerrichting Beleid en Beheer van gezondheidsvoorzieningen aan de Rijksuniversiteit Limburg. In 1985 werd zij als AIO (Assistent In Opleiding) aangesteld bij de vakgroep Beleidswetenschap aan de Rijksuniversiteit Limburg. Momenteel is zij werkzaam als beleidssecretaris van het Regionaal Instituut Geestelijke Gezondheidszorg / Oostelijk Zuid-Limburg te Heerlen. 
Bestuurskosten zijn de kosten die niet zijn gerelateerd aan de directe zorgverlening. Het zijn de kosten van het bestuurlijk apparaat van zowel overheden als particuliere instanties die het gevolg zijn van overheidsbesturing. In deze studie is geprobeerd deze kosten in de gezondheidszorg te meten.

Uit onderzoek is gebleken dat nog zelden is geprobeerd de kosten van wetgeving te meten. Een kant en klare meetmethode is er dan ook niet. In deze studie is geprobeerd de bestuurskosten op drie verschillende manieren te meten om na te gaan of deze methoden geschikt zijn.

Ten eerste is het hoofdstuk "kosten van beleid, administratie en beheer" uit het Financieel Overzicht als uitgangspunt genomen. Aangezien het Financieel Overzicht zich beperkt tot de bestuurskosten bij de overheid, verzekeraars en adviesorganen, zijn deze kosten aangevuld met de bestuurskosten van instellingen.

Ten tweede is de doorlooptijd van artikel 18 van de Wet Ziekenhuisvoorzieningen bepaald. De doorlooptijd is de tijd die verstrijkt tussen het begin en het einde van een procedure. De doorlooptijd is bepaald van de periode die het ministerie nodig heeft om een besluit te nemen of een voorziening onder artikel 18 moet worden gebracht èn van de tijd die verstrijkt tussen de indiening van vergunningaanvragen door Limburgse ziekenhuizen en de antwoorden daarop van de staatssecretaris. Ten derde is de bestede tijd gemeten van de totstandkoming van een plan volgens artikel 4 van de Wet Ziekenhuisvoorzieningen. In deze studie is nagegaan hoeveel tijd de direct betrokken provinciale ambtenaren en adviserende instanties minimaal hebben besteed aan de totstandkoming van het verpleeghuisplan in de provincie Limburg. 